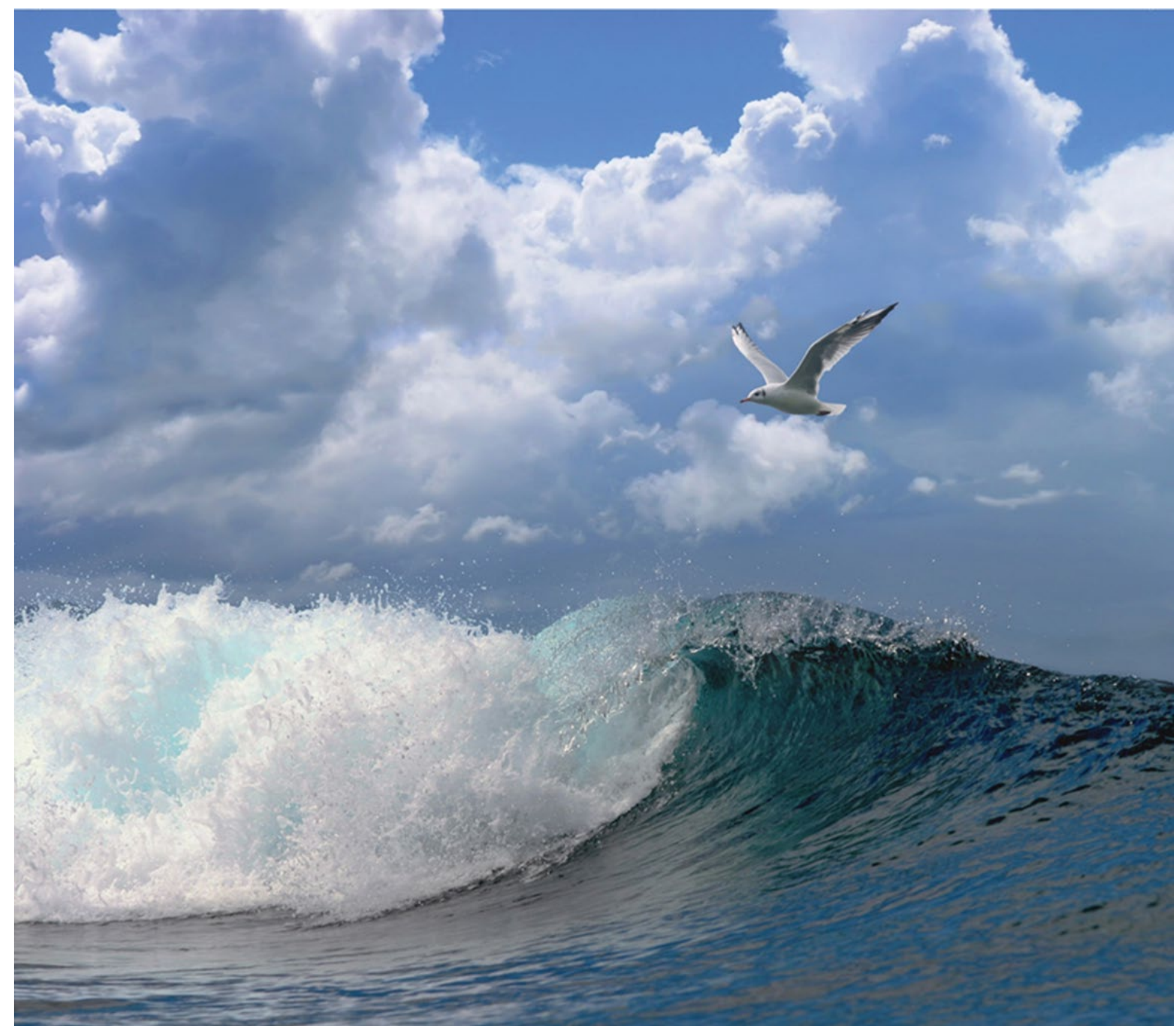

Slow Mill pilot Texel Passende Beoordeling Wet natuurbescherming 


\section{Slow Mill pilot Texel Passende Beoordeling Wet natuurbescherming}

Auteur(s): $\quad$ Ruud Jongbloed, Martijn Keur, Robbert Jak, Michaela Scholl

Wageningen Marine Research 
Keywords: golfslagenergieconverter, Wet natuurbescherming, passende beoordeling, Natura 2000, ecologische effecten, natuurwaarden, stikstofdepositie

Opdrachtgever: NIOZ

Marcel van der Linden

Landsdiep 4

1797 SZ 't Horntje (Texel)

marcel.van.der.linden@nioz.nl

Namens deze:

Elias Consulting

Erwin Meijboom

erwin@eliasconsulting.nl

www.eliasconsulting.nl

Dit rapport is gratis te downloaden van https://doi.org/10.18174/550633

Wageningen Marine Research verstrekt geen gedrukte exemplaren van rapporten.

Wageningen Marine Research is ISO 9001:2015 gecertificeerd.

(c) Wageningen Marine Research

Wageningen Marine Research, instituut binnen de rechtspersoon Stichting

Wageningen Research, hierbij

vertegenwoordigd door Drs. Ir. M.T. van

Manen, directeur bedrijfsvoering

KvK nr. 09098104,

WMR BTW nr. NL 8113.83.696.B16.

Code BIC/SWIFT address: RABONL2U

IBAN code: NL 73 RABO 0373599285
Wageningen Marine Research aanvaardt geen aansprakelijkheid voor gevolgschade, noch voor schade welke voortvloeit uit toepassingen van de resultaten van werkzaamheden of andere gegevens verkregen van Wageningen Marine Research. Opdrachtgever vrijwaart Wageningen Marine Research van aanspraken van derden in verband met deze toepassing.

Alle rechten voorbehouden. Niets uit deze uitgave mag weergegeven en/of gepubliceerd worden, gefotokopieerd of op enige andere manier gebruikt worden zonder schriftelijke toestemming van de uitgever of auteur. 


\section{Inhoud}

Samenvatting

$1 \quad$ Inleiding

1.1 Achtergrond $\quad 8$

1.2 Voortoets en passende beoordeling $\quad 8$

$\begin{array}{lll}1.3 & \text { Doel en toepassingsmogelijkheid van dit rapport } & 8\end{array}$

$\begin{array}{lll}1.4 & \text { Leeswijzer } & 9\end{array}$

$2 \quad$ Wet natuurbescherming $r$

$\begin{array}{lll}2.1 & \text { Beschermingsregime } & 10\end{array}$

2.2 Beschermingsbereik 11

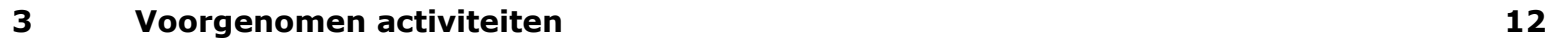

3.1 Beschrijving van plan-/studiegebied 12

$\begin{array}{lll}3.2 & \text { Slow Mill-installatie } & 14\end{array}$

$\begin{array}{ll}3.2 .1 & \text { Pilot project }\end{array}$

$\begin{array}{lll}3.2 .2 & \text { Doorkijk } & 16\end{array}$

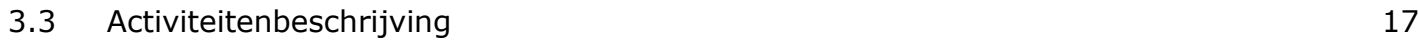

$\begin{array}{lll}\text { 3.3.1 } & \text { Activiteiten bouwfase } & 20\end{array}$

3.3.2 Activiteiten operationele fase $\quad 22$

$\begin{array}{lll}3.3 .3 & \text { Ontmantelingsfase } & 22\end{array}$

$\begin{array}{lll}3.4 & \text { Tijdsplanning } & 23\end{array}$

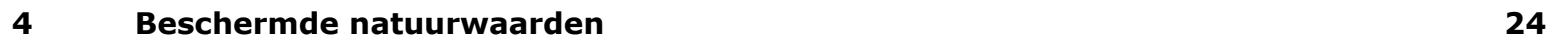

$\begin{array}{lll}4.1 & \text { Natura 2000-gebied Noordzeekustzone } & 24\end{array}$

$\begin{array}{lll}4.1 .1 & \text { Beschermde natuurwaarden } & 24\end{array}$

4.1.2 Relevante beschermde natuurwaarden $\quad 25$

4.2 Natura 2000-gebied Duinen en Lage Land Texel 32

4.2.1 Beschermde natuurwaarden $\quad 32$

4.2.2 Relevante beschermde natuurwaarden $\quad 32$

$\begin{array}{lll}4.3 & \text { Andere beschermde soorten } & 32\end{array}$

4.3.1 Vissen $\quad 33$

4.3.2 Vogels 33

$\begin{array}{lll}4.3 .3 & \text { Zoogdieren } & 33\end{array}$

$5 \quad$ Effectbeschrijving $\quad 34$

$\begin{array}{lll}5.1 & \text { Mogelijke verstoringsfactoren van de activiteiten } & 34\end{array}$

5.2 Mogelijke effecten o.b.v. literatuuronderzoek $\quad 35$

$\begin{array}{lll}5.2 .1 & \text { Botsingen en verstrikkingen } & 36\end{array}$

$\begin{array}{lll}5.2 .2 & \text { Optische verstoring } & 36\end{array}$

$\begin{array}{lll}\text { 5.2.3 Verstoring door geluid (boven water) } & 38\end{array}$

$\begin{array}{lll}5.2 .4 & \text { Verstoring door geluid (onder water) } & 38\end{array}$

$\begin{array}{lll}5.2 .5 & \text { Verandering golfslag } & 39\end{array}$

5.2.6 Verandering dynamiek substraat $\quad 39$

$\begin{array}{lll}\text { 5.2.7 Introductie hard substraat } & 40\end{array}$

$\begin{array}{lll}5.2 .8 & \text { Vertroebeling } & 41\end{array}$

5.2.9 Verontreiniging (toxische stoffen) 41

5.2.10 Elektromagnetische straling $\quad 41$

$\begin{array}{ll}\text { 5.2.11 Stikstofdepositie } & 41\end{array}$ 
$\begin{array}{lll}6.1 & \text { Temporele aanwezigheid } & 45\end{array}$

$\begin{array}{lll}6.2 & \text { Ruimtelijke aanwezigheid } & 48\end{array}$

$\begin{array}{lll}6.3 & \text { Habitattypen } & 48\end{array}$

$\begin{array}{lll}\text { 6.3.1 Globale beoordeling } & 48\end{array}$

$\begin{array}{llr}6.4 & \text { Trekvissen } & 49\end{array}$

$\begin{array}{lll}\text { 6.4.1 Globale beoordeling } & 49\end{array}$

$\begin{array}{ll}\text { 6.4.2 Gedetailleerde beoordeling } & 49\end{array}$

6.5 (Zee)zoogdieren $\quad 52$

6.5.1 Globale beoordeling $\quad 52$

6.5.2 Gedetailleerde beoordeling 53

$\begin{array}{lll}6.6 & \text { Vogels } & 60\end{array}$

$\begin{array}{lll}6.6 .1 & \text { Globale beoordeling } & 60\end{array}$

6.6.2 Gedetailleerde beoordeling 60

$\begin{array}{lll}6.7 & \text { Mitigatie } & 65\end{array}$

$\begin{array}{lll}6.8 & \text { Cumulatie } & 65\end{array}$

$\begin{array}{lll}6.9 & \text { Overzicht gevolgen voor instandhoudingsdoelstellingen } & 68\end{array}$

$\begin{array}{llr}7 & \text { Stikstofdepositie } & \mathbf{7 0}\end{array}$

8 Conclusies $r$

$9 \quad$ Kwaliteitsborging $\quad 72$

$\begin{array}{llr}10 & \text { Literatuur } & 73\end{array}$

$\begin{array}{ll}\text { Verantwoording } & 78\end{array}$

Bijlage 1 Instandhoudingsdoelstellingen Natura 2000-gebied Noordzeekustzone 80

Bijlage 2 Instandhoudingsdoelstellingen Natura 2000-gebied Duinen en Lage Land Texel

Bijlage 3 Kaart met habitattypen van Natura 2000-gebieden Texel

Bijlage 4 Lijst van soorten die op bijlage IV van de habitatrichtlijn, bijlage II van Bern en/of bijlage I van Bonn staan

Bijlage 5 Lijst van waargenomen mariene soorten die op bijlage II, III en IV van de habitatrichtlijn staan

Bijlage 6 Resultaat beoordeling Voortoets Slow Mill pilot Texel

$\begin{array}{llr}\text { Bijlage } 7 & \text { Verspreidingskaarten zeezoogdieren } & 92\end{array}$

$\begin{array}{llr}\text { Bijlage } 8 & \text { Trends voor zeehonden } & 94\end{array}$

$\begin{array}{lll}\text { Bijlage } 9 & \text { Verspreidingskaarten vogels } & 95\end{array}$

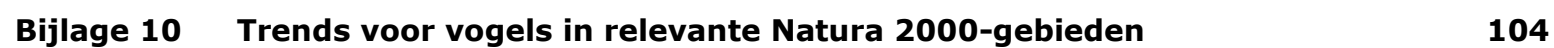

$\begin{array}{llr}\text { Bijlage } 11 & \text { Kwetsbaarheid index van vogelsoorten voor WECs } & 108\end{array}$ 
Bijlage 12 AERIUS ${ }^{\circledR}$-Calculator resultaten voor de verwachte stikstofuitstoot van de voorgenomen activiteiten

109 


\section{Samenvatting}

Initiatiefnemer Slow Mill Sustainable Power BV is voornemens om $4 \mathrm{~km}$ voor de Noordzeekust van Texel, binnen de begrenzing van Natura 2000-gebied Noordzeekustzone, een pilot uit te voeren met de Slow Mill, een moderne 'watermolen' waarmee duurzame energie kan worden gewonnen uit de golfslag van de zee ${ }^{1}$. De Slow Mill behoort tot de groep van de wave energy converters (WECs). De activiteiten die worden verricht in de pilot met de Slow Mill betreffen: het installeren van de converter (ofwel: omvormer) aan een betonnen anker, het leggen van een elektriciteitskabel van de pilotlocatie naar strandpaal 20 nabij De Koog, het testen van deze pilotinstallatie en de ontmanteling. De geprojecteerde doorlooptijd van deze pilot is vijf jaar.

Voor deze pilot met de Slow Mill dient de gebruikelijke vergunningprocedure voor activiteiten in Natura 2000-gebieden te worden doorlopen. Daarvoor is op verzoek van opdrachtgever eerst een voortoets uitgevoerd. Er bleek een passende beoordeling (PB) nodig te zijn, die in dit rapport wordt beschreven.

Er is nog maar weinig over eventuele effecten van WECs op natuurwaarden bekend, waardoor er nog een grote mate van onzekerheid is over de potentiële effecten van WECs. Die onzekerheid maakt dat in de voortoets in sommige gevallen een worst case-benadering moest worden gekozen en/of inschattingen in belangrijke mate op expert judgement gestoeld waren.

Het resultaat van de voortoets was dat wat betreft het Natura 2000-gebied Noordzeekustzone significante gevolgen van de Slow Mill-pilotinstallatie werden uitgesloten voor de volgende instandhoudingsdoelen:

- zeven habitattypen (H1110B, H1140B, H1310A, H1310B, H1330A, H2110, H2190B);

- drie broedvogelsoorten (bontbekplevier, strandplevier en dwergstern);

- twaalf niet-broedvogelsoorten (bergeend, topper, scholekster, kluut, bontbekplevier, zilverplevier, kanoet, drieteenstrandloper, bonte strandloper, rosse grutto, wulp en steenloper).

Daarnaast konden significante gevolgen niet op voorhand worden uitgesloten voor:

- drie trekvissoorten (zeeprik, rivierprik, fint);

- drie zeezoogdiersoorten (bruinvis, grijze zeehond, gewone zeehond);

- $\quad$ zes niet-broedvogelsoorten (roodkeelduiker, parelduiker, aalscholver, eidereend, zwarte zeeeend, dwergmeeuw).

In de voortoets is ook nagegaan of er externe werking zou kunnen optreden op het nabijgelegen Natura 2000-gebied Duinen en Lage Land Texel. Effecten op de instandhoudingsdoelen van dat Natura 2000-gebied werden echter uitgesloten geacht omdat de verstorende factoren van de projectactiviteiten, die zich dus buiten de begrenzing van dat gebied bevinden, niet zodanig doorwerken dat er blootstellingsniveaus worden bereikt waarbij effecten in het Natura 2000-gebied Duinen en Lage Land Texel te verwachten zijn. Hierbij werd een uitzondering gemaakt voor de kleine mantelmeeuw van de broedkolonies op Texel, die ook foerageert voor de kust van De Koog en waarvoor (in het kader van de voortoets) een effect niet op voorhand en met zekerheid kon worden uitgesloten. Ook voor de stikstofdepositie konden in de voortoets effecten niet op voorhand worden uitgesloten.

Voor soorten die staan in bijlage IV van de habitatrichtlijn, bijlage II van Bern en/of bijlage I van Bonn (Bijlage 4) én regelmatig in het studiegebied kunnen voorkomen, waren de conclusies in de voortoets dat:

- $\quad$ effecten worden uitgesloten voor vijf vleermuissoorten (laatvlieger, gewone dwergvleermuis, noordse vleermuis, rosse vleermuis, ruige dwergvleermuis);

- $\quad$ potentieel negatieve effecten niet worden uitgesloten voor vier vissoorten (elft, houting, steur, zalm) en hun populaties.

\footnotetext{
${ }^{1}$ Voor een illustratie zie www.youtube.com/watch?v=in1nnq4LEAA
} 
Doordat in de voortoets is vastgesteld dat voor enkele natuurwaarden niet bij voorbaat kan worden uitgesloten dat significante negatieve effecten kunnen optreden, is een PB noodzakelijk geworden, die in voorliggend rapport is beschreven. Op basis van de beschikbare kennis en informatie is daarin voor de nog in het geding zijnde natuurwaarden eerst gedetailleerd onderzocht hoe groot de mogelijke effecten van de beoogde projectactiviteiten zouden kunnen zijn om vervolgens de inschatting te maken of de instandhoudingsdoelstellingen voor de betreffende soorten daardoor in gevaar kunnen komen. Voor de overige natuurwaarden gelden onveranderd de resultaten en conclusies uit de voortoets.

De nadere beschouwing in deze PB levert als resultaat dat significante gevolgen niet aannemelijk zijn voor de instandhoudingsdoestellingen en populaties van de soorten in kwestie:

- de drie trekvissoorten zeeprik, rivierprik en fint;

- de vier trekvissoorten elft, houting, steur en zalm die geen instandhoudingsdoelstellingen in de Natura 2000-gebied Noordzeekustzone hebben;

- de drie zeezoogdiersoorten (bruinvis, gewone zeehond, grijze zeehond en bruinvis);

- de zes niet-broedvogelsoorten (roodkeelduiker, parelduiker, aalscholver, eidereend, zwarte zee-eend en dwergmeeuw);

- de broedvogelsoort kleine mantelmeeuw van Natura 2000-gebied Duinen en Lage Land Texel.

Vanwege het resultaat van deze PB dat er geen instandhoudingsdoelstellingen zijn waarop significante effecten van de Slow Mill-activiteiten worden verwacht, zijn er geen mitigerende maatregelen nodig.

De cumulatie van effecten behoeft voor de voorgenomen activiteiten niet te worden geanalyseerd, omdat de effecten van de Slow Mill met de best beschikbare informatie, afhankelijk van de soort of habitat, worden ingeschat als afwezig, verwaarloosbaar of zeer gering.

De stikstofberekeningen met de AERIUS Calculator ten behoeve van deze PB door de initiatiefnemer uitgevoerd, hebben geen depositieresultaten opgeleverd boven 0,00 mol/ha/jr. Op basis van deze gegevens kan voor onderhavige PB de conclusie worden getrokken dat significante ecologische effecten van stikstof op de natuurgebieden kunnen worden uitgesloten. 


\section{Inleiding}

\subsection{Achtergrond}

Initiatiefnemer Slow Mill Sustainable Power BV is voornemens om voor de Noordzeekust van het Waddeneiland Texel een pilot uit te voeren met een energieconverter waarmee duurzame energie kan worden gewonnen uit de golfslag van de zee. Hierbij gaat het om het installeren en testen van een full-scale model op $4 \mathrm{~km}$ voor de kust van Texel ter hoogte van strandpaal 20 en het leggen van de kabel voor het aanlanden van de opgewekte energie van de pilotlocatie naar strandpaal 20. In de toekomst zou een golfenergiepark met zes converters kunnen ontstaan met een vermogen van in totaal 2,4 MW. De sterkte van de elektriciteitskabel voor de pilotinstallatie voorziet daar al in.

Voordat de proefopstelling met één converter kan worden gerealiseerd moeten de nodige milieuvergunningen worden verkregen. In het kader van de procedure volgens het Besluit Milieueffectrapportage (2018) moet een m.e.r.-beoordeling worden doorlopen.

Deze passende beoordeling (PB) ex Wet natuurbescherming (Wnb) maakt daar onderdeel van uit.

\subsection{Voortoets en passende beoordeling}

Omdat de Slow Mill-pilot geen complex project betreft, had de initiatiefnemer ervoor gekozen om eerst een voortoets te laten uitvoeren (Jongbloed et al. 2020). In deze voortoets werd echter vastgesteld dat er soorten zijn waarvoor significante gevolgen voor de instandhoudingsdoelstellingen niet op voorhand konden worden uitgesloten. Dit werd bevestigd door het bevoegd gezag in hun beoordeling van de voortoets. De belangrijkste inhoudelijke constateringen van het bevoegd gezag waren dat:

- voor sommige instandhoudingsdoelstellingen vanwege een aantal onzekerheden, significante effecten niet op voorhand kunnen worden uitgesloten en derhalve een PB dient te worden opgesteld;

- de veronderstelde potentiële effecten van elektromagnetische straling van de transportkabel van de Slow Mill waarschijnlijk niet realistisch zijn;

- $\quad$ een nadere aanduiding van het belang van het studiegebied ten opzichte van het geheel van de Noordzeekustzone dient te worden gegeven;

- de toetsing van het effect van de extra stikstofdepositie aan de norm niet in beeld is gebracht;

- $\quad$ er mogelijk ook andere manieren zijn om de stikstofemissie te berekenen (verwezen werd naar de mobiele werktuigenbenadering).

In deze PB zal op deze constateringen worden ingegaan. $\mathrm{Zij}$ is het vervolg op de voortoets en bevat wederom de beschrijvingen van de voorgenomen activiteiten, beschermde natuurwaarden, en de effectbeschrijving en effectbeoordeling uit de voortoets, met als uitbreiding een nadere gedetailleerde toetsing van de gevolgen van de voorgenomen activiteiten op de Natura 2000-instandhoudingsdoelstellingen waarvoor in de voortoets significante gevolgen nog niet konden worden uitgesloten. Als de resultaten daartoe aanleiding geven wordt aanvullend onderzocht of er mitigerende maatregelen noodzakelijk en mogelijk zijn en of er cumulatie kan optreden met andere plannen en projecten.

\subsection{Doel en toepassingsmogelijkheid van dit rapport}

Dit rapport geeft de resultaten van de PB voor het project Slow Mill pilot Texel met één converter. Het doel van de PB is vast te stellen of en welke significante negatieve ecologische effecten op de instandhoudingsdoestellingen voor beschermde natuurwaarden te verwachten zijn. De PB geeft daarmee alle actuele resultaatbeoordelingen van de voorgenomen activiteiten en vervangt de 
voortoets. Aan de hand van dit rapport kan de initiatiefnemer in overleg met de vergunningsverlener treden. Het bevoegd gezag kan deze PB gebruiken om tot een besluit over de vergunbaarheid van het initiatief te komen.

\subsection{Leeswijzer}

Voor de beoordeling is een indeling gekozen die tevens als leeswijzer dient. Na de inleiding (dit hoofdstuk) en een beknopte toelichting op de systematiek van de Wnb (hoofdstuk 2) worden de volgende onderdelen beschreven ${ }^{2}$ :

- de locatie, aard en planning van de projectactiviteiten (hoofdstuk 3);

- de relevante beschermde soorten en habitattypen (hoofdstuk 4);

- de relevante verstoringsfactoren en effecten van WECs en specifiek van de Slow Millpilotinstallatie (hoofdstuk 5);

- $\quad$ een gedetailleerde analyse van deze effecten op de relevante instandhoudingdoestellingen, en voor zover aan de orde: mitigatie en cumulatie, eindigend met een overzicht van de gevolgen voor de instandhoudingsdoelstellingen (hoofdstuk 6);

- de stikstofdepositie voor het meest aannemelijke scenario qua uitvoering van het project, inclusief toetsing aan de norm (hoofdstuk 7);

- de conclusies (hoofdstuk 8).

\footnotetext{
${ }^{2}$ Daarvoor zijn de beschrijvende delen (grotendeels integraal) uit de voortoets (Jongbloed et al., 2020) overgenomen.
} 


\section{Wet natuurbescherming}

In dit hoofdstuk wordt een zeer beknopte toelichting gegeven op de Wet natuurbescherming $\left(\mathrm{Wnb}^{3}\right)$, de meest relevante begrippen en de systematiek die wordt gehanteerd in het kader van de vergunningverlening. Ook worden de betrokken Natura 2000-gebieden kort geïntroduceerd.

\subsection{Beschermingsregime}

De Wnb is de Nederlandse uitwerking van de richtlijnen 79/43/EEG van de Raad van de Europese Gemeenschappen van 2 april 1979 inzake het behoud van de vogelstand (Vogelrichtlijn; afgekort: VR) en 92/43/EEG van de Raad van de Europese Gemeenschappen van 21 mei 1992 inzake de instandhouding van de natuurlijke habitats en de wilde flora en fauna (Habitatrichtlijn; afgekort HR).

Bij de natuurwaarden die worden beschermd onder de Wnb gaat het om de bescherming van de dieren- en plantensoorten en gebieden waarvoor deze beide richtlijnen en de verdragen van Bonn en Bern voorschriften geven, aangevuld met andere soorten, die eveneens bescherming behoeven. De VR en HR (en dus ook de Wnb) kennen twee belangrijke beschermingsinstrumenten: het aanwijzen van zgn. speciale beschermingszones (SBZ; art. 4 VR) en de lijst met gebieden van communautair belang (art. $4 \mathrm{HR}$ ).

SBZ is de officiële naam voor een Natura 2000-gebied. De essentie van het beschermingsregime is dat voor deze gebieden instandhoudingsdoelstellingen worden vastgesteld die niet in gevaar mogen worden gebracht. Om dit te kunnen toetsen zijn projecten (en andere handelingen) die gevolgen kunnen hebben voor de soorten en habitats van de betreffende gebieden in beginsel vergunningplichtig.

Cruciaal is de aard en ernst van de eventuele effecten die van een project kunnen uitgaan. Wanneer significant negatieve gevolgen op de instandhoudingsdoelstellingen niet kunnen worden uitgesloten, kan slechts dan een vergunning worden verleend als er geen Alternatieven voor het project zijn, er Dwingende redenen van groot openbaar belang zijn, en Compenserende maatregelen worden genomen (kort: ADC-toets genoemd).

Allereerst moet daarom worden vastgesteld: zijn er negatieve effecten? Concreter: is er sprake van verstoring van soorten en/of een verslechtering van de kwaliteit van habitats of van habitats van soorten? Zo ja, dan is de volgende vraag: zijn die negatieve effecten significant?

Zoals reeds in paragraaf 1.2 geschetst zullen activiteiten die geen effect op de betrokken Natura 2000-gebieden hebben zonder vergunning doorgang kunnen vinden. Wanneer de analyse echter aangeeft dat (significant-)negatieve effecten niet met zekerheid kunnen worden uitgesloten, moet het project aan een PB worden onderworpen. Bij de genoemde effecten kan het ook om effecten op Natura 2000-gebieden gaan die buiten het plangebied liggen. Een plangebied hoeft niet per se zelf in een Natura 2000-gebied te liggen om toch effecten op een Natura 2000-gebied te kunnen hebben (externe werking).

Doorslaggevend is dus of een mogelijk negatief effect wel of niet significant kan zijn. Een activiteit heeft significante effecten wanneer daardoor de instandhoudingsdoelstellingen van een of meer betrokken Natura 2000-gebieden in gevaar (kunnen) worden gebracht. Aan het significantie-begrip moet een objectieve inhoud worden gegeven. Tegelijkertijd moet die inschatting gebaseerd zijn op de specifieke situatie die van toepassing is. De beoordeling wordt per effect gemaakt, maar ook de mogelijke opeenstapeling van effecten (cumulatie) moet onderzocht worden.

\footnotetext{
3 De Wet natuurbescherming (Wnb) is sinds 1 januari 2017 van kracht en vervangt drie oude wetten: de Natuurbeschermingswet 1998, de Boswet en de Flora- en Faunawet.
} 


\subsection{Beschermingsbereik}

De bescherming van natuurwaarden valt uiteen in de bescherming van soorten en van gebieden (habitats).

\section{Soortenbescherming}

De bescherming van soorten heeft betrekking op de volgende dieren:

- $\quad$ alle van nature in Nederland in het wild levende vogels, zoals bedoeld in art. 1 van de VR

- $\quad$ in het wild levende dieren van bijlage IV onderdeel a bij de HR

- $\quad$ in het wild levende dieren van bijlage II bij het Verdrag van Bern

- $\quad$ in het wild levende dieren van bijlage I bij het Verdrag van Bonn

- de eieren, voortplantingsplaatsen of rustplaatsen van hierboven bedoelde dieren

Het betreft:

\begin{tabular}{|l|l|}
\hline Soortgroep & Soorten \\
\hline Vissen & Elft, fint, houting, steur, zalm, rivierprik, zeeprik (bijlage 4, bijlage 5) \\
\hline Vogels & Zo goed als alle soorten: zie lijsten (bijlage 4, bijlage 5) \\
\hline Vleermuizen & Zo goed als alle soorten: zie lijsten (bijlage 4, bijlage 5) \\
\hline Zeezoogdieren & Zo goed als alle soorten: zie lijsten (bijlage 4, bijlage 5) \\
\hline
\end{tabular}

Lijsten met alle soorten zijn in te zien via de link http://minez.nederlandsesoorten.nl/content/wetnatuurbescherming-16-december-2015-paragraaf-32-beschermingsregime-soorten-van-de .

\section{Gebiedsbescherming}

Beschermd zijn de door Nederland aangewezen Natura 2000-gebieden. Voor het onderhavige Slow Mill-pilotproject zijn de relevante Natura 2000-gebieden: Noordzeekustzone en - vanwege de mogelijke externe werking van projectactiviteiten op extern gelegen beschermingsgebieden - ook het Natura 2000-gebied Duinen en Lage Land Texel. Voor de stikstofberekening komen daar de Natura 2000-gebieden Duinen Den Helder-Callantsoog en Waddenzee (automatisch) nog bij.

Gedetailleerde beschrijvingen van de kenmerken van de onderhavige Natura 2000-gebieden en de te beschermen habitattypen, habitatsoorten en vogelsoorten zijn te vinden in hoofdstuk 4 van dit rapport waarin onder andere informatie is verwerkt van de volgende webpagina's:

- Kaartenbijlage Natura 2000-beheerplan Noordzeekustzone Periode 2016-2022; https://www.rwsnatura2000.nl/gebieden/noordzeekustzone/nzkz_documenten/default.aspx

- Actuele documenten en kaarten met betrekking tot de aanwijzing van het Natura 2000-gebied Noordzeekustzone; https://www.natura2000.nl/gebieden/friesland/noordzeekustzone

- Actuele documenten en kaarten met betrekking tot de aanwijzing van het Natura 2000-gebied Duinen en lage land Texel; https://www.natura2000.nl/gebieden/noord-holland/duinen-enlage-land-texel

- [website van alle Nederlandse provincies]; https://www.bij12.nl/onderwerpen/natuur-enlandschap/natura-2000-beheerplannen/2-duinen-en-lage-land-texel/

\section{Algemene verplichting Wnb}

In de $\mathrm{Wnb}$ is ook een algemene zorgplicht opgenomen die inhoudt dat planten en dieren (en hun directe leefomgeving) niet onnodig vernield/gedood of verstoord mogen worden. De focus ligt hierbij op individuele dieren en niet de natuurdoelen op een hoger niveau: het populatieniveau van een beschermde soort. De initiatiefnemer is dus verantwoordelijk voor een adequate naleving van deze algemene zorgplicht tijdens de uitvoering van de werkzaamheden. 


\section{Voorgenomen activiteiten}

In dit hoofdstuk wordt een beschrijving gegeven van het plangebied, de voorgenomen projectactiviteiten en de tijdsplanning voor het Slow Mill-pilotproject. Voor het beschrijven van de activiteiten wordt informatie gebruikt uit het projectplan Slow Mill pilot Texel en extra informatie zoals namens de initiatiefnemer is aangeleverd door Elias Consulting.

\subsection{Beschrijving van plan-/studiegebied}

De Slow Mill-pilotinstallatie komt ca. 4 km uit de kust van Texel ter hoogte van paal 20, zie Figuur 1. Deze locatie valt binnen de grenzen van het Natura 2000-gebied Noordzeekustzone. Daarnaast wordt vanaf de installatie op zee een elektriciteitskabel getrokken die bij paal 20 aan land komt en daar aan het bestaande elektriciteitsnet wordt gekoppeld. De aanlandlocatie op het strand ligt, net als de installatie op zee, in het Natura 2000-gebied Noordzeekustzone en op zo'n 200-300 m van het Natura 2000-gebied Duinen en Lage Land Texel af; zie Figuur 1 en Figuur 2.

Voor de onderhavige PB is het van belang om twee gebieden te onderscheiden, namelijk het plangebied en het studiegebied. Deze worden als volgt gedefinieerd:

- Plangebied (projectgebied): het gebied rondom de Slow Mill-pilotinstallatie en de bekabeling, waar de voorgenomen projectactiviteiten zullen worden uitgevoerd.

- Studiegebied (onderzoeksgebied): het gebied dat wordt beschouwd voor de beoordeling van mogelijke effecten op habitattypen en -soorten. De grootte van dit gebied wordt bepaald door de reikwijdte (afstand) van de gevolgen. Deze worden behandeld in hoofdstuk 6 . Het is belangrijk op te merken dat de reikwijdte sterk kan verschillen per verstoringsfactor: optische verstoring, bovenwatergeluid, onderwatergeluid, elektromagnetische straling, etc. Voor de begrenzing van het studiegebied kan een afstand van $5 \mathrm{~km}$ tot de Slow Mill-pilotinstallatie en de kabels worden aangehouden als maximale verstoringsafstand voor onderwatergeluid. Deze inschatting is gebaseerd op de studie naar verstoring van zeezoogdieren door vaaractiviteiten van werkschepen (Pondera Consult, 2018) en wordt hier geacht ruim te zijn. Voor wat betreft de stikstofdepositie op land is de begrenzing conform hetgeen de AERIUS Calculator daarvoor aangeeft. 


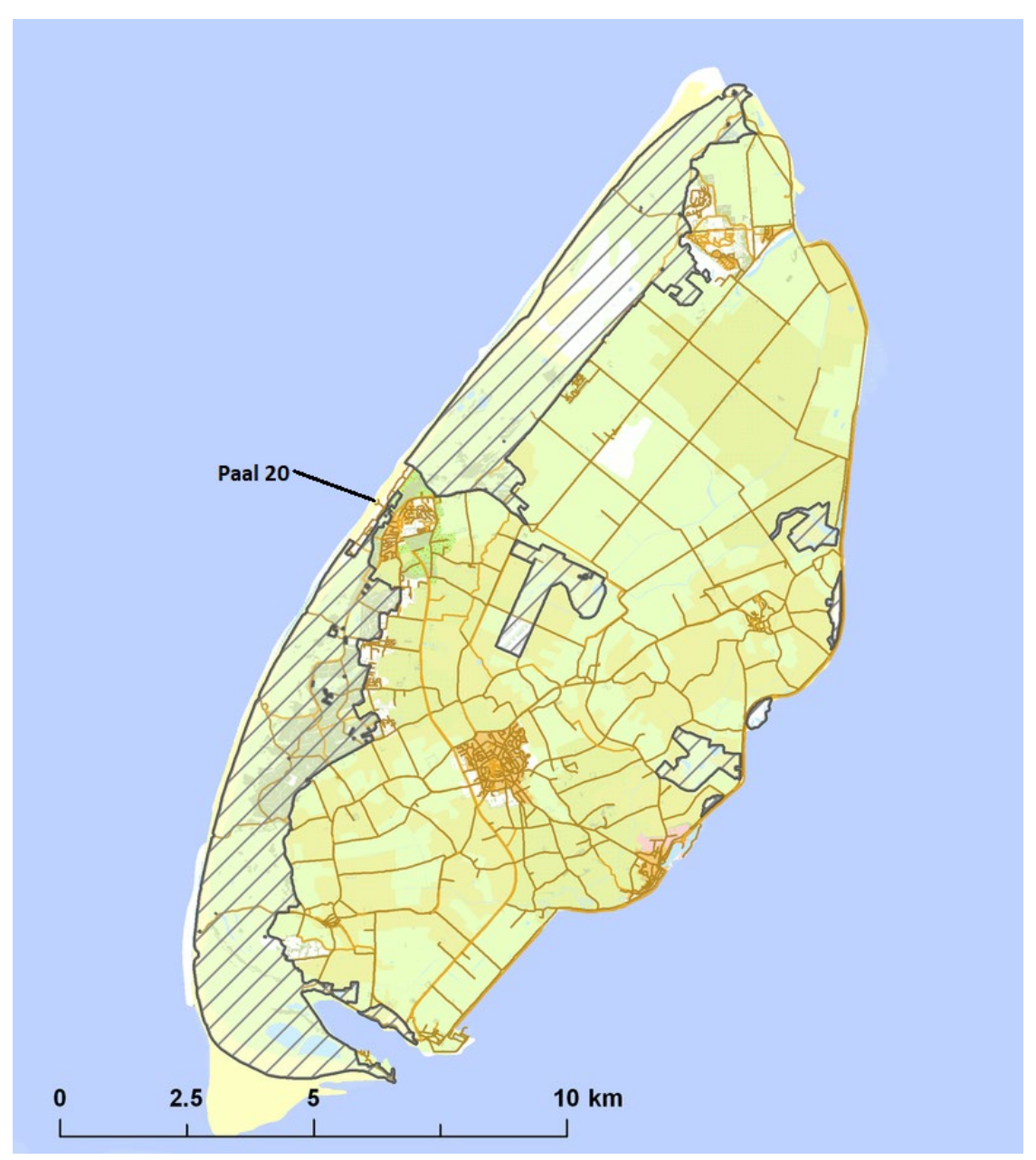

Figuur 1 Kaart van Texel met de positie van (het anker van) de Slow Mill-pilotinstallatie en de beide opties voor het kabeltracé met de aanlandingslocaties bij paal 20. Het Natura 2000-gebied Duinen en Lage Land Texel is grijs gearceerd.; bron kaart: https://nl.wikipedia.org/wiki/Bestand:Natura2000__Duinen_en_Lage_Land_Texel.png 


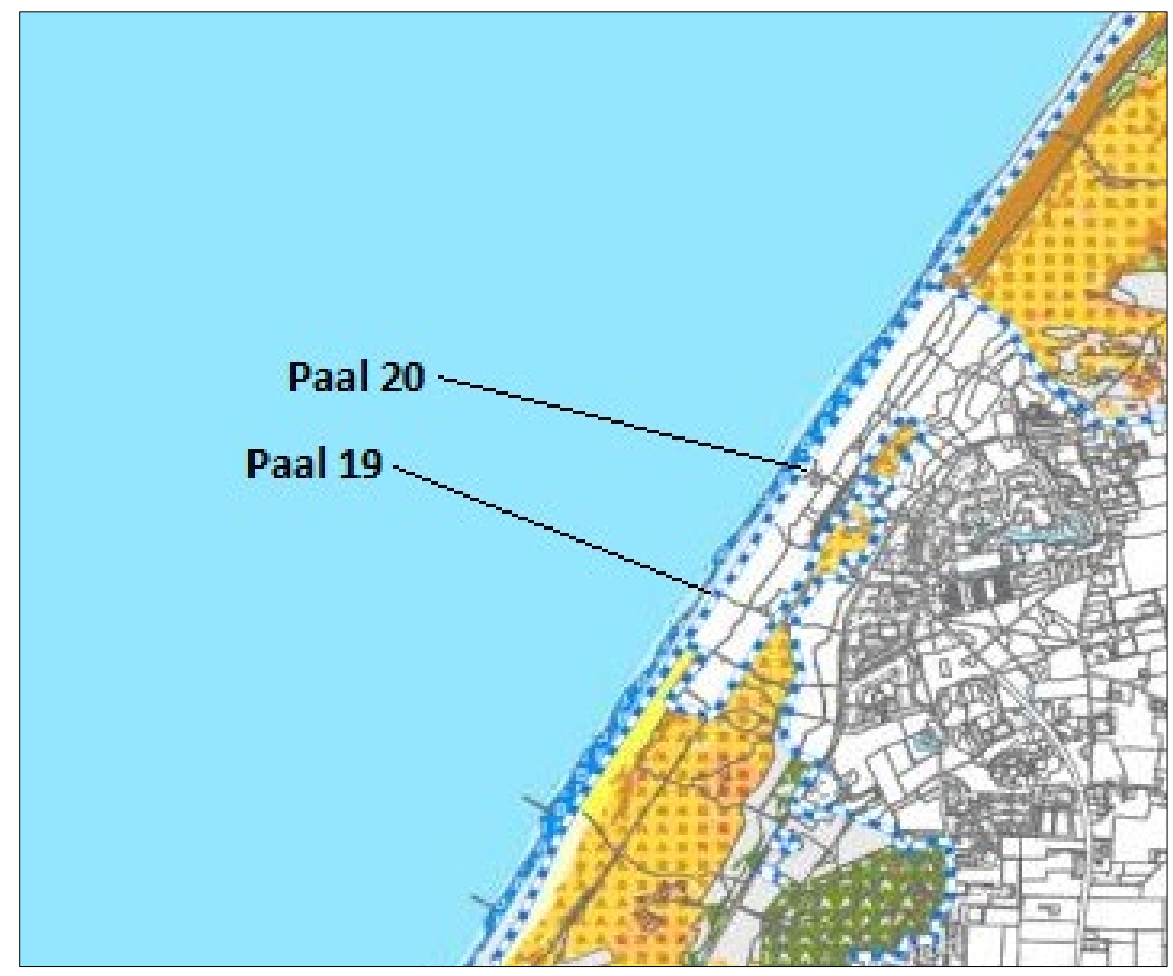

Figuur 2 Deel van het plangebied. Blauwe stippellijn: begrenzing van Natura 2000-gebied Duinen en Lage Land Texel. Aangeduid: de mogelijke aanlandlocaties voor de elektriciteitskabel bij paal 20 (met - inmiddels vervallen- alternatief: paal 19). Bron (kaart): https://nl.wikipedia.org/wiki/Lage_Land_van_Texel

\subsection{Slow Mill-installatie}

\subsubsection{Pilot project}

De Slow Mill (de converter zelf) is een zogenaamde heave-and-surge golfenergieconverter. Dit is een nieuw type golfenergieconverter. Reeds bestaande converters worden geschaard onder de Engelse termen: point-absorbers, attentuators, oscillating water column terminators of overtopping devices. De Slow Mill-converter heeft een horizontale drijver die net boven het water uitkomt en dwars daarop een verticale drijver, die met een cilinder en zuigerstang verbonden is aan de horizontale drijver (zie Figuur 4). Onder de horizontale drijver bevinden zich twee blad- of lamelsystemen met elk drie lamellen. De afstand tussen de lamellen varieert van 21-35 cm. De afstand tussen de bovenste lamellen en de drijver is $30 \mathrm{~cm}$. De Slow Mill-converter is aan de onderzijde verbonden aan een anker (zie Figuur 5) dat op de zeebodem staat. De hoogte van de converter vanaf het draaipunt op het anker, inclusief de horizontale drijver is circa $15 \mathrm{~m}$.

De Slow Mill-installatie maakt gebruik van de golven door, in resonantie met zowel de op- als neergaande bewegingen van de golf, een cirkelbeweging om te zetten in een verticale beweging in de cilinder, die een $400 \mathrm{~kW}$-generator aandrijft in de horizontale drijver. De opgewekte energie kan worden opgeslagen in een opslagbuffer en daarna via de elektriciteitskabel worden toegeleverd aan het elektriciteitsnet op land.

Bewegende delen van de Slow Mill onder water zijn slechts twee onderdelen: de bevestiging met het anker (in alle kompasrichtingen) en de zuigerstang (op en neer). De lamellen zelf bewegen niet. Er vindt geen onderhoud onder water plaats. Voor inspectie en vervanging van de (bewegende) delen wordt de Slow Mill-installatie aan het wateroppervlak gebracht door lucht in het anker te blazen zodat het geheel gaat drijven. Daarvoor wordt de kabel, voordat die de zeebodem ingaat, in een lus, 
maximaal $5 \mathrm{~m}$ van het anker vandaan, bovenop de zeebodem gelegd. Deze lus wordt verzwaard zodat er geen losse delen in de waterkolom zweven. Zie daarvoor - bij wijze van illustratie - Figuur 3

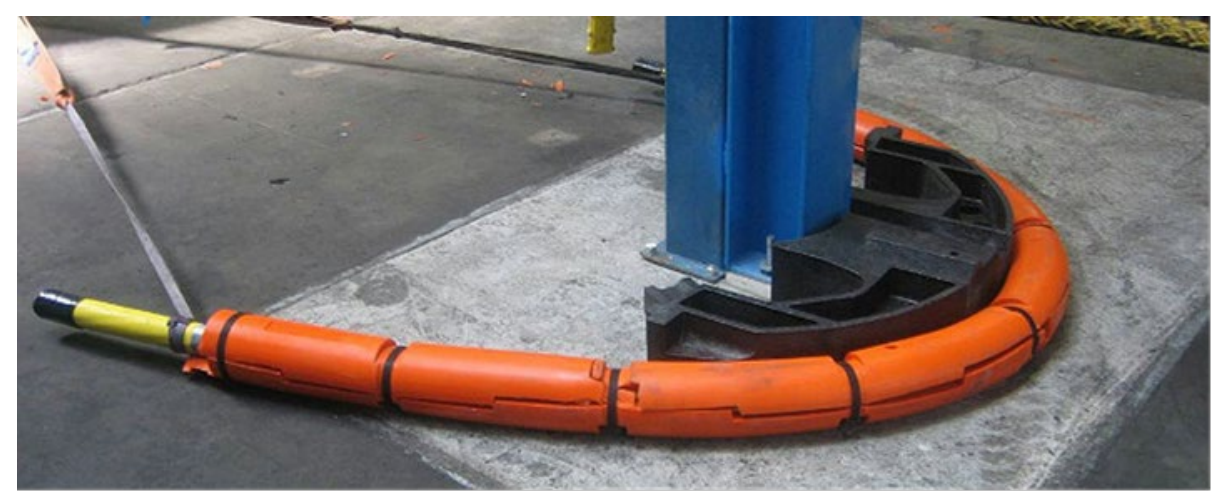

Figuur 3 Illustratie van het materiaal ter verzwaring van de kabel-voor de Slow Mill, voor het deel van kabel waar dat nodig is (bron: Lankhorst)

Voor de Slow Mill-pilotinstallatie wordt geen aangroei-remmende coating gebruikt. Wel zal op de zes lamellen anti-fouling worden toegepast die voor de start van het project zal worden getest. Daarbij zal geen chemische of zgn. zelfslijpende antifouling worden toegepast. Er zal, afhankelijk van de uitkomsten van deze test, een keuze worden gemaakt uit:

- $\quad$ Elektrische anti-fouling (current spikes)

- Spuitkoppen

- Wrapping folie

- Micro-haartjes (finsulate)

- UV-led

- Akoestisch

- Wissers

- Geen anti-fouling

Uit oogpunt van veiligheid zal rondom de Slow Mill-pilotinstallatie in een veiligheidszone moeten worden voorzien waarin geen andere activiteiten plaatsvinden (milieuzonering). De initiatiefnemer acht daarvoor een gebied met een straal van circa $30 \mathrm{~m}$, voldoende. Hieraan ligt de berekening van het ruimtebeslag door de installatie ten grondslag (hoogte van de Slow Mill: 15 m; draaicirkel bij 45 graden: circa sinus 45 graden $* 15 \mathrm{~m}=10,6 \mathrm{~m}$ ) waaraan een extra marge is toegevoegd. 


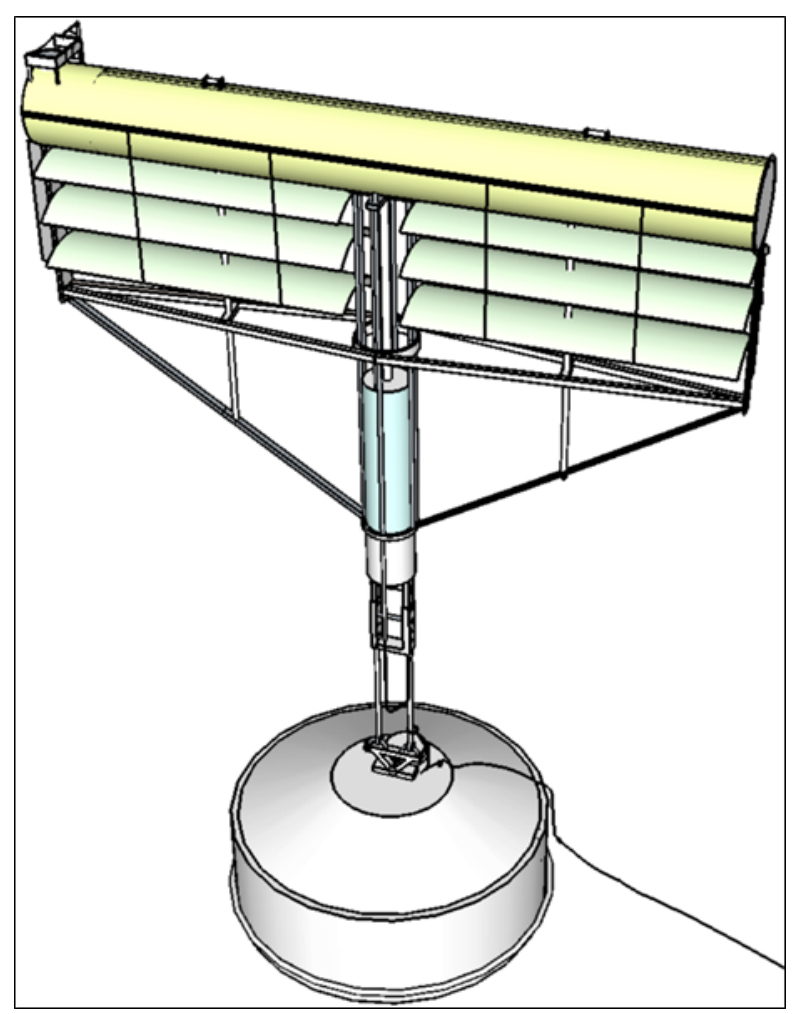

Figuur 4 Prototype Slow Mill-pilotinstallatie: converter, anker en kabelaansluiting. De hoogte gemeten vanaf het draaipunt op het anker is circa 15 m. Bron: Slow Mill Sustainable Power

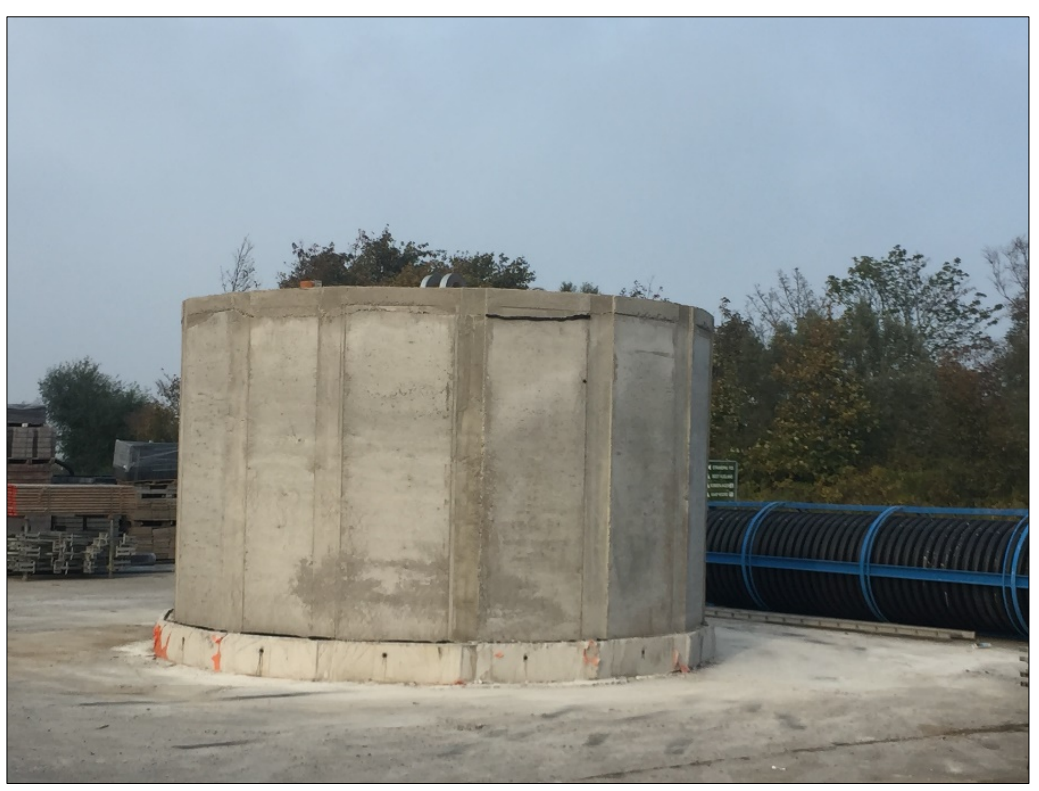

Figuur 5 Betonnen anker voor de Slow Mill-pilotinstallatie. Bron: Slow Mill Sustainable Power BV

\subsubsection{Doorkijk}

Deze PB richt zich op het pilotproject: de plaatsing van één converter. Om alvast een doorkijk te geven van de mogelijkheden in de toekomst, wordt in Figuur 6 een parkopstelling getoond. Daarin zijn 
vijf converters te zien maar het idee is om een park met zes converters te realiseren, die versprongen zijn opgesteld en een totaal vermogen van 2,4 MW hebben. Als na of tijdens ${ }^{4}$ de geprojecteerde doorlooptijd van de pilot (vijf jaar) voor uitbreiding met meerdere converters wordt gekozen, zal de Slow Mill-converter van het pilotproject niet worden ontmanteld maar daar onderdeel van uitmaken.

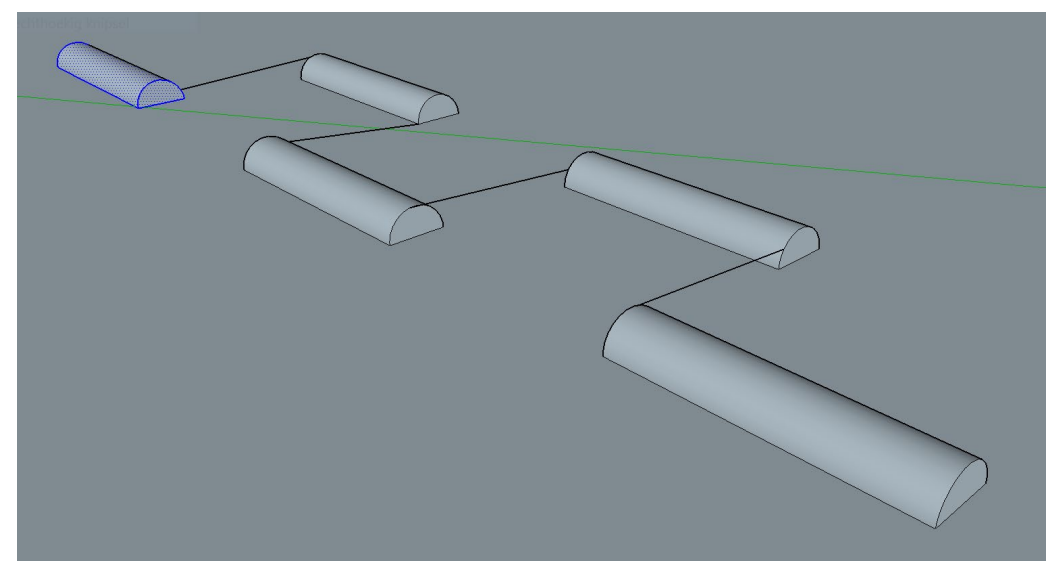

Figuur 6 Impressie van een parkopstelling met meerdere Slow Mill-converters. Getoond zijn de horizontale drijvers aan het wateroppervlak. Bron: Slow Mill Sustainable Power BV

\subsection{Activiteitenbeschrijving}

Voor de PB van het Slow Mill-pilotproject worden drie fases onderscheiden omdat de samenstelling, aard en omvang van de activiteiten in elke fase anders (kunnen) zijn, waardoor ook de effecten, afzonderlijk of in combinatie, verschillend kunnen doorwerken. In de bouw- en ontmantelingsfase zullen de activiteiten over het algemeen relatief kort van duur zijn, terwijl de activiteiten in de operationele fase aanhoudend of frequenter zijn, wat over de hele projectperiode gerekend een grotere milieubelasting kan geven, maar bij dieren ook de kans op gewenning aan de verstoringsbron kan betekenen.

\section{Bouwfase}

- Plaatsen elektriciteitskabels (in zee en via strand/duinen naar aansluitpunt met bestaande elektriciteitsnet)

- Graafwerkzaamheden

- Vaarwerkzaamheden

- Plaatsen van het anker

- Vaarwerkzaamheden

- Plaatsen van de Slow Mill-converter

- Vaarwerkzaamheden

Operationele fase

- Slow Mill-pilotinstallatie in bedrijf

- Inregelen, preventief en correctief onderhoud en onderzoek

- Vaarwerkzaamheden

Ontmantelingsfase

- Opruimen Slow Mill-pilotinstallatie (alle onderdelen, inclusief kabel)

- Vaarwerkzaamheden

- Graafwerkzaamheden

\footnotetext{
${ }^{4}$ uitbreiding naar meerdere converters vergt een nieuwe vergunning, want die uitbreiding valt buiten de aanvraag die mede wordt gebaseerd op onderhavige passende beoordeling
} 
In de volgende paragrafen en Tabel 1 wordt gedetailleerde uitleg gegeven van iedere individuele activiteit, inclusief de frequentie, periode van uitvoering en welke schepen daarbij gebruikt zullen worden. Alle activiteiten worden overdag uitgevoerd. 
Tabel 1 De voorziene activiteiten in de bouwfase, operationele fase en ontmantelingsfase van de Slow Mill-pilotinstallatie, met frequentie, duur/tijdstip van de dag, uitvoeringsperiode en benodigd transportmiddel. Bron: initiatiefnemer.

\begin{tabular}{|c|c|c|c|c|c|}
\hline Activiteit & Toelichting & \begin{tabular}{|l|} 
Frequentie \\
(totale periode is \\
5 jaar)
\end{tabular} & Duur en tijdstip & $\begin{array}{l}\text { Uitvoerings- } \\
\text { periode }\end{array}$ & $\begin{array}{l}\text { Transportmiddel/ } \\
\text { materieel }\end{array}$ \\
\hline \multicolumn{6}{|l|}{ Bouwfase } \\
\hline $\begin{array}{l}\text { Transport en plaatsen } \\
\text { anker }\end{array}$ & $\begin{array}{l}\text { Betonnen anker } 12 \mathrm{~m} \\
\text { afzinken }\end{array}$ & eenmalig & $\begin{array}{l}1 \text { dag, overdag } \\
\text { (heen en terug) }\end{array}$ & maart-aug & $\begin{array}{l}\text { Offshore support vessel } \\
\text { RAM } 57 \mathrm{~m} 600 \mathrm{pk} \text { diesel } \\
\text { of vergelijkbaar, The } \\
\text { Empiric } 12 \mathrm{~m}, 190 \mathrm{pk} \\
\text { diesel }\end{array}$ \\
\hline $\begin{array}{l}\text { Graaf- en } \\
\text { vaarwerkzaamheden } \\
\text { t.b.v. elektriciteitskabel in } \\
\text { zee }\end{array}$ & $\begin{array}{l}\text { Kabel } 50 \mathrm{~mm} \text { op } 2-3 \mathrm{~m} \\
\text { diepte ingraven in de } \\
\text { zeebodem, vanaf de } \\
\text { locatie in zee tot de } \\
\text { aanlandlocatie (paal 20) }\end{array}$ & eenmalig & $\begin{array}{l}\text { dag (overdag) } \\
\text { met rustig weer } \\
\text { (kabeltrace onder } \\
\text { water), Empiric } \\
\text { vaart heen en } \\
\text { terug }\end{array}$ & maart-aug & $\begin{array}{l}\text { Offshore support vessel } \\
\text { RAM } 57 \mathrm{~m} 600 \text { pk diesel } \\
\text { of vergelijkbaar, The } \\
\text { Empiric } 12 \mathrm{~m}, 190 \mathrm{pk} \\
\text { diesel }\end{array}$ \\
\hline $\begin{array}{l}\text { Graafwerkzaamheden } \\
\text { t.b.v. elektriciteitskabel in } \\
\text { strand/duin } \\
\\
\end{array}$ & $\begin{array}{l}\text { Kabel ingraven in strand } \\
\text { en door de duinen naar } \\
\text { aansluitpunt op } \\
\text { elektriciteitsnet ( } 200 \mathrm{~m} \\
\text { tot parkeerplaats, of } 400 \\
\text { m tot bebouwde kom) }\end{array}$ & eenmalig & 3 dagen (overdag) & maart-aug & $\begin{array}{l}\text { Graafmachine, LPG, 130- } \\
560 \mathrm{~kW}, \text { Stage V, } \\
\text { bouwjaar } 2019\end{array}$ \\
\hline $\begin{array}{l}\text { Transport en plaatsen } \\
\text { Slow Mill-converter }\end{array}$ & $\begin{array}{l}\text { Slow Mill slepen naar } \\
\text { locatie, anker ophalen, } \\
\text { Slow Mill-converter } \\
\text { koppelen aan anker, } \\
\text { anker weer laten } \\
\text { afzinken }\end{array}$ & eenmalig & $\begin{array}{l}1 \text { dag, overdag } \\
\text { (heen en terug) }\end{array}$ & maart-aug & $\begin{array}{l}\text { Offshore support vessel } \\
\text { RAM } 57 \mathrm{~m} 600 \text { pk diesel } \\
\text { of vergelijkbaar, The } \\
\text { Empiric } 12 \mathrm{~m}, 190 \mathrm{pk} \\
\text { diesel }\end{array}$ \\
\hline \multicolumn{6}{|c|}{\begin{tabular}{|l|l|}
$\begin{array}{l}\text { Operationele fase (incl. } \\
\text { testfase) }\end{array}$ & \\
\end{tabular}} \\
\hline Slow Mill-pilotinstallatie & In bedrijf & $\begin{array}{l}\text { continu m.u.v. } \\
\text { onderhouds- } \\
\text { periodes }\end{array}$ & 5 jaar & jan-dec & $\begin{array}{l}\text { Slow Mill 400, potentieel } \\
\text { vermogen } 400 \mathrm{~kW}\end{array}$ \\
\hline $\begin{array}{l}\text { Vaarwerkzaamheden } \\
\text { t.b.v. onderzoek en } \\
\text { onderhoud }\end{array}$ & \begin{tabular}{|l|} 
Varen onderhouds- \\
platform van haven van \\
Den Helder naar locatie \\
op zee voor gepland \\
onderhoud en \\
onderzoek/testen
\end{tabular} & $\begin{array}{l}10 \text { keer heen en } \\
10 \text { keer terug } \\
\text { voor } \\
\text { onderzoek/testen } \\
\text { en } 2 x \text { per jaar ( }= \\
10 \text { keer heen en } \\
10 \text { keer terug) } \\
\text { voor regulier } \\
\text { onderhoud; } \\
\text { totaal } 20 \text { keer } \\
\text { heen en } 20 \text { keer } \\
\text { terug), gemiddeld } \\
\text { over } 5 \text { jaar dus } \\
4 x \text { per jaar heen } \\
\text { en } 4 x \text { per jaar } \\
\text { terug. }\end{array}$ & $\begin{array}{l}5 \text { jaar, } 4 \text { dagen per } \\
\text { jaar gemiddeld, } \\
\text { overdag }\end{array}$ & jan-dec & $\begin{array}{l}\text { The Empiric } 12 \mathrm{~m}, 190 \mathrm{pk} \\
\text { diesel }\end{array}$ \\
\hline \multicolumn{6}{|l|}{ Ontmantelingsfase } \\
\hline $\begin{array}{l}\text { Opruimen Slow Mill- } \\
\text { converter }\end{array}$ & $\begin{array}{l}\text { Anker omhoog blazen, } \\
\text { Slow Mill loskoppelen }\end{array}$ & eenmalig & $\begin{array}{l}1 \text { dag, overdag } \\
\text { (heen en terug) }\end{array}$ & maart-aug & $\begin{array}{l}\text { Offshore support vessel } \\
\text { RAM } 57 \text { m } 600 \text { pk diesel } \\
\text { of vergelijkbaar, Empiric } \\
12 \mathrm{~m}, 190 \text { pk diesel }\end{array}$ \\
\hline Vaarwerkzaamheden & $\begin{array}{l}\text { Anker en Slow Mill- } \\
\text { converter naar haven } \\
\text { van Den Helder slepen }\end{array}$ & eenmalig & $\begin{array}{l}1 \text { dag, overdag } \\
\text { (heen en terug) }\end{array}$ & maart-aug & $\begin{array}{l}\text { Offshore support vessel } \\
\text { RAM } 57 \text { m } 600 \text { pk diesel } \\
\text { of vergelijkbaar, Empiric } \\
12 \mathrm{~m}, 190 \text { pk diesel }\end{array}$ \\
\hline $\begin{array}{l}\text { Opruimen kabel van/uit } \\
\text { zeebodem }\end{array}$ & $\begin{array}{l}\text { Lostrekken kabel en } \\
\text { verwijderen }\end{array}$ & eenmalig & $\begin{array}{l}1 \text { dag, overdag } \\
\text { (heen en terug) }\end{array}$ & maart-aug & $\begin{array}{l}\text { Offshore support vessel } \\
\text { RAM } 57 \text { m } 600 \text { pk diesel } \\
\text { of vergelijkbaar, Empiric } \\
12 \mathrm{~m}, 190 \text { pk diesel }\end{array}$ \\
\hline $\begin{array}{l}\text { Opruimen kabel van } \\
\text { strand/duin }\end{array}$ & $\begin{array}{l}\text { Lostrekken kabel en } \\
\text { verwijderen }\end{array}$ & eenmalig & 1 dag, overdag & maart-aug & $\begin{array}{l}\text { Graafmachine, LPG, 130- } \\
560 \mathrm{~kW} \text {, Stage V, } \\
\text { bouwjaar } 2019\end{array}$ \\
\hline
\end{tabular}




\subsubsection{Activiteiten bouwfase}

In de bouwfase zijn er drie activiteiten ten behoeve van het realiseren van de pilotinstallatie (voor de uitvoering in de tijd zie paragraaf 3.4):

- Plaatsen van het anker

- Plaatsen elektriciteitskabel in zee en strand, en door de duinen

- Plaatsen van de Slow Mill-converter

Deze activiteiten gaan gepaard met vaar- en graafwerkzaamheden.

\subsubsection{Plaatsen van het anker}

Op de pilotlocatie (Figuur 1) wordt in de maand april van het eerste uitvoeringsjaar eenmalig een betonnen anker van circa $12 \mathrm{~m}$ doorsnee geplaatst (Figuur 5). Het anker wordt met een installatieplatform vanuit de haven van Den Helder naar de testlocatie in zee gesleept (Figur 7 ). Dit platform, The Empiric, heeft een 190 pk dieselmotor. Voorzien is een innovatieve aandrijving met steamjets. ${ }^{5}$. Aangekomen bij de testlocatie worden de luchtkleppen van het anker opengezet zodat het volloopt met water en naar de bodem afzinkt.

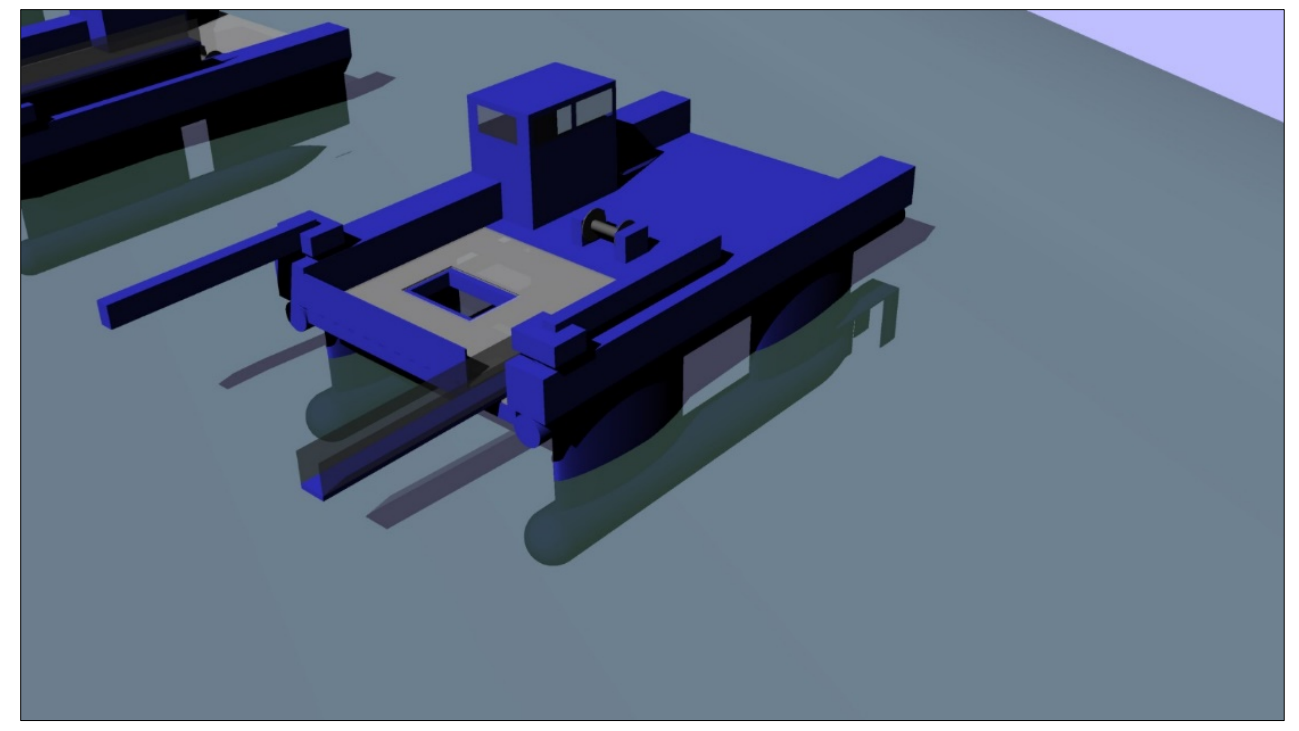

Figuur 7 Schematisch ontwerp installatie-/onderhoudsplatform The Empiric (lengte: ca. 12 m, motorvermogen: 190 pk); bron: Slow Mill Sustainable Power BV

\subsubsection{Aanleggen van de elektriciteitskabel}

In de periode maart-mei van het eerste uitvoeringsjaar wordt er een elektriciteitskabel aangelegd. Deze heeft een doorsnede van circa $50 \mathrm{~mm}$ en is geschikt voor een spanning van circa $10 \mathrm{kV}$ en een vermogen van circa 2 MVA. Het voorziene tracé verloopt vanaf de Slow Mill-pilotlocatie in zee naar strandpaal 20 ter hoogte van De Koog, en verder door de duinen naar een punt waar de aansluiting met het bestaande elektriciteitsnetwerk kan worden gemaakt (nog niet exact bekend). Uit risicooverwegingen komt de kabel in zee op een diepte van 2-3 m onder het zeebodemoppervlak te liggen. Eerst wordt het reeds afgezonken anker omhooggehaald door middel van het inspuiten van lucht waardoor het gaat drijven. Dan wordt de elektriciteitskabel aan het anker bevestigd. De kabel wordt naar de zeebodem geleid en daar, voordat de kabel wordt ingegraven, op een afstand van max. $5 \mathrm{~m}$ vanaf het anker in een verzwaarde lus op de zeebodem gelegd om speling te creëren voor het herhaaldelijk kunnen ophalen van de installatie. Vanaf het aanlandpunt op het strand wordt de kabel ingegraven in het strand en de duinen, naast het bestaande pad (Badweg), tot aan de eerste

\footnotetext{
${ }^{5}$ Technisch is het mogelijk om de energie daarvoor vanuit de Slow Mill te 'tanken' waardoor er geen uitstoot van verbrandingsgassen zoals kooldioxide (CO2) of stikstofoxide (NOx) ontstaat. Met deze optie is in deze PB geen rekening gehouden omdat niet vaststaat of en op welk moment deze techniek wordt ingezet.
} 
mogelijkheid voor de koppeling met het elektriciteitsnet (200 m tot parkeerplaats of $400 \mathrm{~m}$ tot bebouwde kom). Er waren oorspronkelijk twee aanlandopties in beeld; de locatie bij paal 19 is inmiddels vervallen (Figuur 8 en Figuur 9). Uitgangspunt is dat de kabel niet door Natura 2000-gebied wordt geleid. Voor het leggen van de kabel in zee wordt een 600 pk diesel schip van 57 m, de offshore support vesse/ MV RAM of vergelijkbaar schip, gebruikt; voor het graafwerk aan land een LPGgraafmachine (130-560 kW, Stage V, 2019).

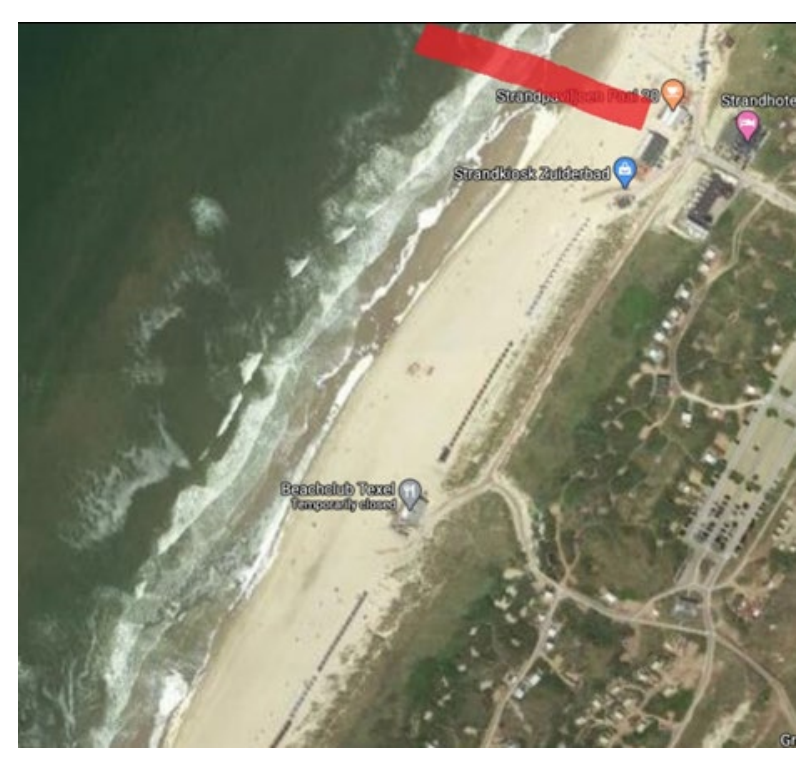

Figuur 8 Locatie aanlanding elektriciteitskabel. Ingetekend (rode lijn): de aanlanding bij paal 20 (in het noorden). Bron (kaart): Google maps. Niet weergegeven: de aansluiting op het bestaande elektriciteitsnet.

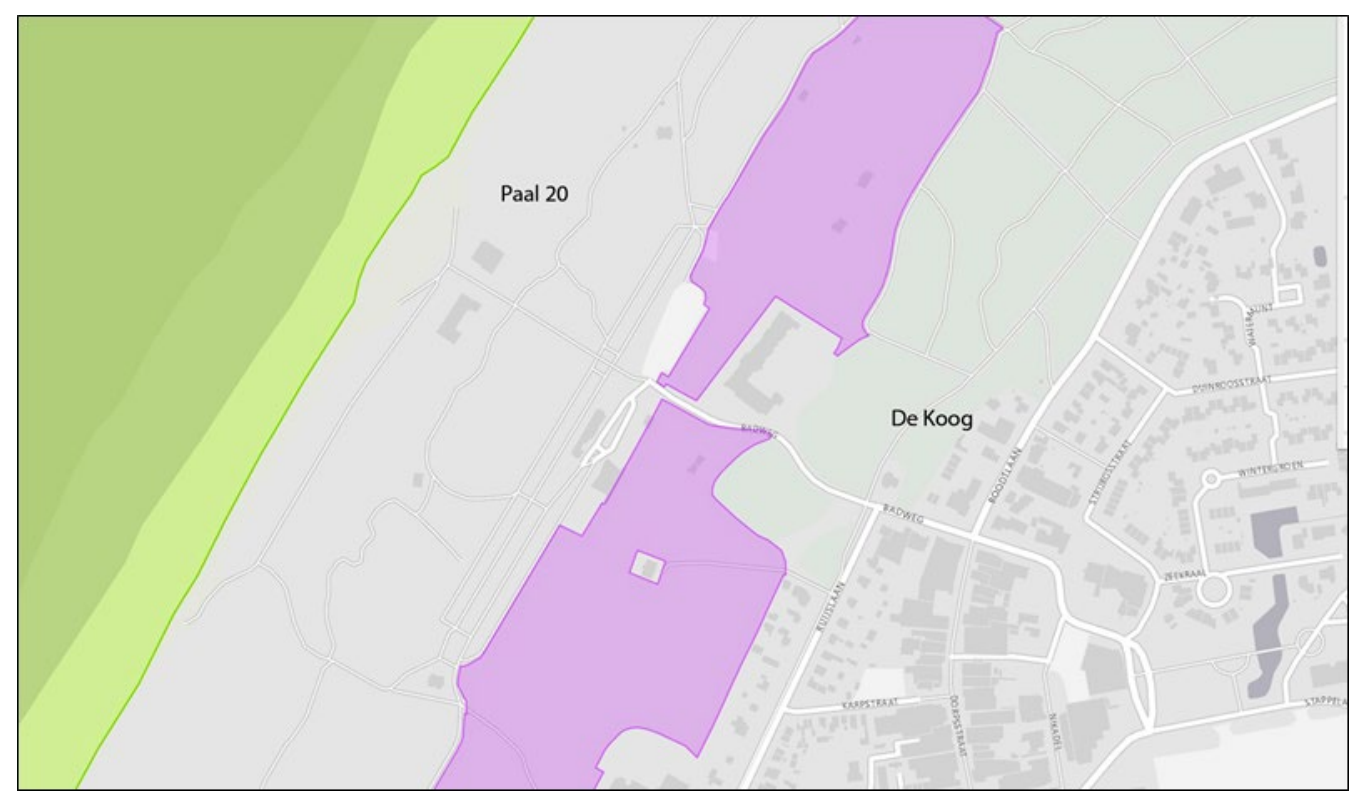

Figuur 9 Situatie bij De Koog. Bij aanlanding bij paal 20 verloopt het kabeltracé vanaf het strand langs/onder de Badweg (geen onderdeel van Natura 2000-gebied Duinen Lage Land Texel; paars). In groen: deel van Natura 2000-gebied Noordzeekustzone. Bron (kaart):

https://geocontent.rvo.nl/Natura2000/Gebiedskaart/index.html?gebiednaam=Noordzeekustzone

\subsubsection{Plaatsen van de Slow Mill-converter}

In mei 2022 wordt de Slow Mill-converter van de haven van Den Helder naar de locatie op zee versleept door het gebruik van MV RAM of vergelijkbaar schip. De Slow Mill-converter met zijn 20 m brede drijver wordt op de locatie op zee aan het anker bevestigd. Daarvoor wordt het anker eerst 
weer, door het inspuiten van lucht waardoor het gaat drijven, van de zeebodem opgehaald. Wanneer de converter geplaatst is, wordt de hele installatie weer naar de zeebodem afgezonken. Het drijvende gedeelte van de Slow Mill-pilotinstallatie wordt getoond in Figuur 10.

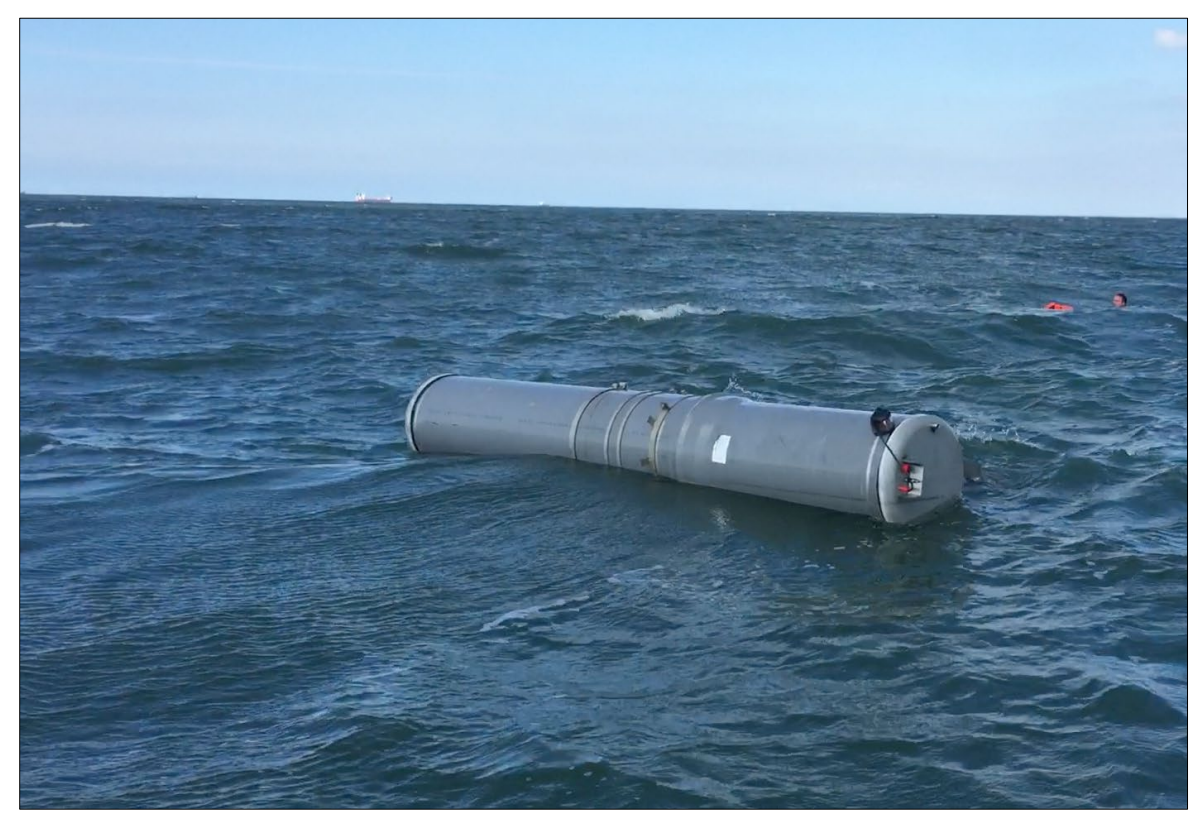

Figuur 10 Slow Mill-pilotinstallatie (bovenwatergedeelte). Bron: Slow Mill Sustainable Power BV

\subsubsection{Activiteiten operationele fase}

De operationele fase start op het moment dat de Slow Mill-pilotinstallatie volledig is geplaatst (in meijuli van het eerste uitvoeringsjaar). De eerste 6-9 maanden (met één stormseizoen) gelden als testperiode. In de operationele fase zijn er twee activiteiten: Testen en onderzoek en daarnaast gepland onderhoud, die gepaard gaan met vaarwerkzaamheden. Tijdens de gehele periode dat de Slow Mill-pilotinstallatie in werking is, wordt er regelmatig, ongeveer 20 keer in totaal, (preventief en correctief) onderhoud gepleegd en/of onderzoek uitgevoerd. Dit wordt gedaan met het installatie/onderhoudsplatform The Empiric. Het is mogelijk dat de Slow Mill-converter en/of het anker daarvoor boven water gehaald moeten worden. Het onderhoud zal altijd overdag uitgevoerd worden.

\subsubsection{1}

Zoals vermeld in Tabel 1 zijn in de operationele fase voor diverse montage-, onderhouds- en testwerkzaamheden (in het kort: het inregelen van de installatie) tien transporten met het installatie/onderhoudsplatform The Empiric vanuit de haven van Den Helder naar de Slow Mill-pilotlocatie voorzien. Ook deze vinden uitsluitend overdag plaats.

Daarnaast vindt twee keer per jaar regulier onderhoud aan de installatie plaats waarvoor de installatie boven water gehaald wordt.

\subsubsection{Ontmantelingsfase}

In de ontmantelingsfase is er maar één activiteit: het opruimen van de gehele Slow Millpilotinstallatie, dus inclusief de kabel (zie tabel 1). Deze activiteit gaat vooral gepaard met vaarwerkzaamheden. Met het installatie-/onderhoudsplatform The Empiric wordt het anker omhoog geblazen en de converter losgekoppeld, waarna beide naar de haven van Den Helder worden versleept met behulp van de MW RAM of vergelijkbaar schip. De hele operatie duurt één dag en vindt overdag plaats. Ook de kabel wordt compleet verwijderd. Dat zal echter sneller en eenvoudiger gaan dan de aanleg ervan. De kabel hoeft niet te worden uitgegraven maar wordt losgetrokken. Voor het opruimen van de kabel 
uit de zeebodem wordt ook één dag aangehouden. Het werk wordt uitgevoerd door de service vessel RAM of vergelijkbaar schip. Het opruimen van de kabel op land (strand/duin) vindt plaats door het opgraven en verwijderen van de kabel met een LPG graafmachine (130-560 kW, Stage V, 2019). Het werk duurt één dag en wordt overdag uitgevoerd.

\subsection{Tijdsplanning}

De planning in de tijd van de verschillende activiteiten in de bouw-, operationele en ontmantelingsfase voor het Slow Mill-pilotproject is schematisch weergegeven in Tabel 2. De gehele projectperiode omvat vijf jaar. De startmaand is van belang omdat verstorende factoren verschillend effect kunnen hebben afhankelijk van de maand waarin de werkzaamheden plaatsvinden. In deze PB wordt er voor de effectbeoordeling van uitgegaan dat de bouwwerkzaamheden van het project in maart (eerste uitvoeringsjaar) starten, wat enigszins 'worst-case' is (zie paragraaf 6.1).

Tabel 2 Planning van het Slow Mill pilot Texel project. Bron: initiatiefnemer.

\begin{tabular}{|c|c|c|c|c|c|c|c|c|c|c|c|c|c|c|c|}
\hline \multirow[b]{2}{*}{ Type activiteit* } & \multicolumn{10}{|c|}{2022 (eerste uitvoeringsjaar) } & \multicolumn{3}{|c|}{2023} & \multirow{2}{*}{\begin{tabular}{|l|}
$2023-$ \\
2027 \\
Apr-Mar \\
\end{tabular}} & \multirow{2}{*}{\begin{tabular}{|l|}
2027 \\
Apr \\
\end{tabular}} \\
\hline & Mar & Apr & Mei & Jun & Jul & Aug & Sep & Okt & Nov & Dec & Jan & Feb & Mar & & \\
\hline \multicolumn{16}{|l|}{ Bouwfase } \\
\hline \multicolumn{16}{|l|}{\begin{tabular}{|l|} 
Plaatsen \\
elektriciteitskabel zee
\end{tabular}} \\
\hline \multicolumn{16}{|l|}{ Plaatsen anker } \\
\hline \multicolumn{16}{|l|}{$\begin{array}{l}\text { Plaatsen Slow Mill- } \\
\text { converter }\end{array}$} \\
\hline \multicolumn{16}{|l|}{ Plaatsen kabel aan land } \\
\hline \multicolumn{16}{|c|}{ Operationele fase (incl. testfase) } \\
\hline \multicolumn{16}{|c|}{\begin{tabular}{|l|l|l|} 
Slow Mill-pilotinstallatie & & \\
testfase & & \\
\end{tabular}} \\
\hline \multicolumn{16}{|l|}{\begin{tabular}{|l} 
Gepland onderhoud \\
londerzoek \\
\end{tabular}} \\
\hline \multicolumn{16}{|l|}{$\begin{array}{l}\text { Slow Mill-pilotinstallatie } \\
\text { regulier in bedrijf }\end{array}$} \\
\hline \multicolumn{16}{|l|}{ Ontmantelingsfase } \\
\hline $\begin{array}{l}\text { Opruimen Slow Mill- } \\
\text { converter, anker en } \\
\text { kabel** }\end{array}$ & & & & & & & & & & & & & & & \\
\hline
\end{tabular}




\section{Beschermde natuurwaarden}

In hoofdstuk 2 en 3 is beschreven welke natuurwaarden onder de Wnb worden beschermd. Dit betreft onder meer de bescherming van soorten en habitats onder de HR en de VR. De projectlocatie van de voorgenomen activiteiten is gelegen in het Natura 2000-gebied Noordzeekustzone. Vanwege de mogelijke externe werking vanuit het plangebied op het nabijgelegen Natura 2000-gebied Duinen en Lage Land Texel, wordt daar dus ook aandacht aan besteed. Gezamenlijk vormen deze twee gebieden het studiegebied van deze PB. NB De beschermde gebieden wat betreft de stikstofdepositie volgen automatisch uit de AERIUS Calculator zelf.

\subsection{Natura 2000-gebied Noordzeekustzone}

In deze paragraaf worden eerst alle beschermde natuurwaarden van het Natura 2000-gebied Noordzeekustzone aangeduid (Figuur 11), waarna de voor het onderhavige project geselecteerde, relevante natuurwaarden worden besproken wat betreft hun globale verspreiding in het gebied en de geldende instandhoudingsdoelstellingen.

\subsubsection{Beschermde naturwarden}

Het Natura 2000-gebied Noordzeekustzone bestaat uit de kustwateren van de Noordzee langs de Noord-Hollandse kust ten noorden van Bergen en langs de hele waddenkust tot aan de Eems. De zeewaartse grens ligt op de doorgaande NAP -20 m-dieptelijn. Langs de Noord-Hollandse vastelandskust ligt de grens aan de landzijde op de laagwaterlijn; het Natura 2000-gebied bestaat daar uit de met water bedekte kustzone. Op de Waddeneilanden behoren de stranden tot aan de duinvoet ook tot de Noordzeekustzone. Op de eilanden ligt de bovengrens op de duinvoet, die daardoor dynamisch is: bij duinaangroei verplaatst de grens zich zeewaarts en bij duinafslag landinwaarts met de duinvoet mee.

De Noordzeekustzone heeft een oppervlakte van circa 144.474 ha en grenst aan de Natura 2000gebieden van de Waddeneilanden en de Waddenzee. De onderlinge samenhang tussen deze gebieden is sterk. Zo spelen de stranden en de vooroevers van de Noordzeekustzone een belangrijke rol als zandleveranciers voor de eilanden. Ook is er veel wisselwerking van sedimentatie- en erosieprocessen tussen de Noordzeekustzone, de eilanden en de Waddenzee met geulen, ondieptes, platen, kwelders en duinen (Ministerie van Infrastructuur en Milieu, 2016a).

Op basis van de HR zijn zes habitattypen, waarvan één met twee subtypen, en zes soorten als Natura 2000-waarde aangewezen. Voor de VR zijn drie soorten als broedvogel en 18 als niet-broedvogel aangewezen; voor één soort betreft de aanwijzing zowel broedvogel als niet-broedvogel. In het voorliggende rapport is uitgegaan van de instandhoudingsdoelstellingen voor habitattypen, habitatsoorten en vogelsoorten zoals beschreven in het concept-aanwijzingsbesluit dat met het wijzigingsbesluit Noordzeekustzone in 2010 definitief is geworden (Ministerie van ELI, 2010). 


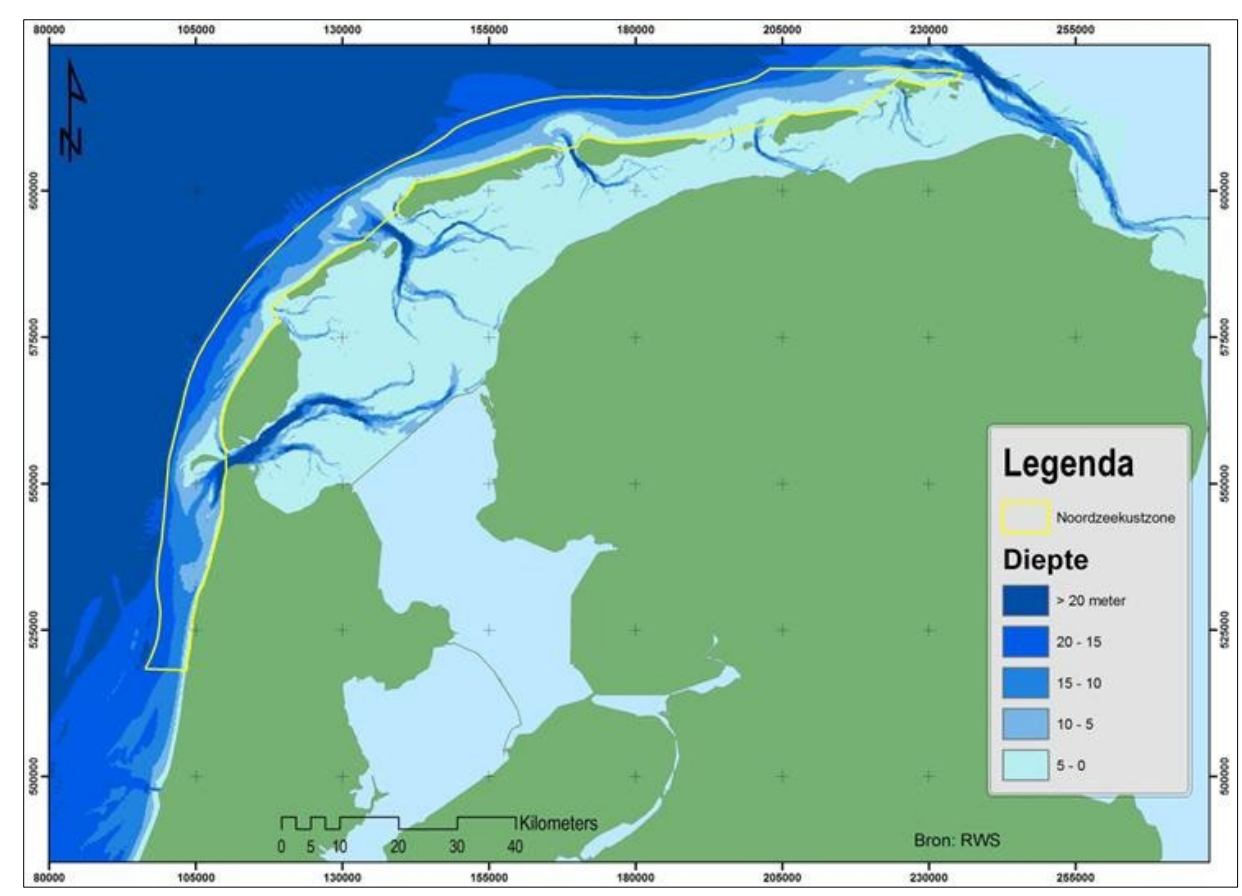

Figuur 11 Ligging Natura 2000-gebied Noordzeekustzone (gele lijn) en omgeving (bron: Ministerie van Infrastructuur en Milieu, 2016a)

In het wijzigingsbesluit Noordzeekustzone (Ministerie van ELI, 2010) zijn de instandhoudingsdoelstellingen van dat gebied beschreven. In Bijlage 1 van dit rapport zijn alle instandhoudingsdoelstellingen met hun landelijke staat van instandhouding (SvI), doelstelling oppervlakte/omvang leefgebied, doelstelling kwaliteit/kwaliteit leefgebied en doelstelling populatie/populatie omvang schematisch weergegeven. In het beheerplan 2016-2022 voor het Natura 2000-gebied Noordzeekustzone zijn de doelstellingen uitgewerkt en aangegeven hoe die bereikt moeten worden door middel van maatregelen (Ministerie van Infrastructuur en Milieu, 2016a).

\subsubsection{Relevante beschermde natuurwaarden}

De lijst van habitattypen en HR- en VR-soorten die beschermd worden in Natura 2000-gebied Noordzeekustzone is lang (zie Bijlage 1), maar niet alle zijn relevant in relatie tot de beoordeling van de activiteiten van het Slow Mill-pilotproject bij Texel. De habitattypen en soorten die niet in het studiegebied voorkomen, kunnen ook niet worden blootgesteld aan potentiële effecten van de Slow Mill-pilotinstallatie en worden dan ook niet betrokken in de effectbeoordeling voor de PB (hoofdstuk 6). Voor de selectie is gebruik gemaakt van informatie uit het beheerplan Noordzeekustzone (Ministerie van Infrastructuur en Milieu, 2016a, b), de onderliggende rapporten van Jak et al. (2014a, 2014b) en het beheerplan Texel (Rijksdienst voor Ondernemend Nederland, 2016). Van de geselecteerde natuurdoelen, dat wil zeggen de habitattypen, habitatsoorten, broedvogels en nietbroedvogels die wel relevant zijn voor deze PB, zijn de kenmerken en doelstellingen hieronder beknopt beschreven. Tabel 3 geeft het overzicht.

\subsubsection{Habitattypen}

In de Noordzeekustzone zijn zes verschillende habitattypen (soms met subtypen) voor bescherming aangewezen. In het rapport Natura 2000-doelen in de Noordzeekustzone. Van doelen naar opgaven voor natuurbescherming zijn deze habitattypen uitvoerig beschreven (Jak et al.; 2014a, 2014b). Niet al deze habitattypen komen voor bij de aanlandlocatie van de kabel bij paal 20, de Slow Milllocatie $4 \mathrm{~km}$ uit de kust of in het gebied daartussen. De duin- en kwelderhabitattypen liggen op grote afstand van het plangebied: dichtstbijzijnde locatie is de Slufter op circa $6 \mathrm{~km}$ ten noorden van paal 20. Verwacht wordt daarom dat eventuele effecten van de Slow Mill-pilotinstallatie zich daar niet zullen doen gelden. Habitattype H1110B (permanent overstroomde zandbanken) en H1140B (slik-en zandplaten) komen wel voor in het plangebied, namelijk voor de kust nabij paal 20. De habitattypen 
H1310A (zilte pioniersbegroeiingen; zeekraal), H1310B (zilte pioniersbegroeiingen; zeevetmuur), H1330A (schorren en zilte graslanden; buitendijks), H2110 (embryonale duinen) en H2190B (vochtige duinvalleien; kalkrijk) komen niet voor in het Natura 2000-gebied Noordzeekustzone bij Texel (Jak et al.; 2014a, 2014b). De dichtstbijzijnde locatie waar deze habitattypen aanwezig zijn, is de Slufter, vallend onder Natura 2000-gebied Duinen en Lage Land Texel.

De kenmerken en de doelstellingen van de twee habitattypen die relevant zijn voor deze PB, worden hieronder nader beschreven.

\section{H1110B: Permanent overstroomde zandbanken}

Het habitattype 'permanent met zeewater van geringe diepte overstroomde zandbanken, subtype Noordzeekustzone' is aanwezig in vrijwel de gehele Noordzeekustzone. Bijna het gehele plangebied bestaat uit dit habitattype, met uitzondering van een smalle strook van het strand, zoals ook bij paal 20 (zie Figuur 1) dat bestaat uit habitattype 1140B (zie Bijlage 3, Figuur 15).

Het habitattype bestaat uit zandbanken in ondiepe delen van de zee die voortdurend onder water staan. Naast de zandbanken maken ook de tussenliggende laagten en geulen er deel van uit. De overstroomde zandbanken hebben een hoge dynamiek van water en bodem. Door inwerking van golven is de stabiliteit van het sediment in de ondiepe delen laag. De Slow Mill-installatie heeft mogelijk een effect op de dynamiek (zie uitleg in paragraaf 5.2.5.). Ten gevolge van bodemberoering (vormen van visserij, kustsuppleties) is het bodemleven in de Noordzeekustzone, ook in de van nature relatief minder dynamische delen, niet stabiel in samenstelling en overwegend opgebouwd uit individurijke, maar soortenarme levensgemeenschappen. De bodemfauna bestaat hier vooral uit soorten met een korte levensduur en/of hoge reproductiesnelheid (zoals borstelwormen en bepaalde schelpdieren). De bodemleefgemeenschap van vis is eveneens instabiel.

Verder uit de kust neemt door toenemende diepte en stabiliteit van de zeebodem de biodiversiteit toe. Hier is een (potentieel) soortenrijke levensgemeenschap aanwezig bestaande uit relatief langlevende soorten. Op de bodem komen vele soorten tweekleppigen, stekelhuidigen en kreeftachtigen voor. Ook is het een belangrijk opgroeigebied voor jonge vis.

Voor habitattype H1110B geldt een behoudsdoelstelling voor de omvang en een verbeterdoelstelling voor de kwaliteit van het gebied. De kwaliteit is als matig ongunstig beoordeeld. Om dit te verbeteren zijn verschillende oplossingsrichtingen beschreven, waaronder verduurzaming van de visserij, onderzoek en monitoring, optimalisatie uitvoering kustverdediging en beheer en onderhoud (Ministerie van Infrastructuur en Milieu, 2016a).

\section{H1140B: Slik- en zandplaten}

Het habitattype 'slik- en zandplaten, subtype Noordzeekustzone' bestaat uit zandplaten en stranden in ondiepe kustgebieden. Zandplaten komen in de zeegaten voor en verplaatsen zich in de richting van het zandtransport. Het habitattype is zeer dynamisch. Door getijdewerking staan de platen afwisselend droog en onder water, en zijn de platen onbegroeid. Veel voorkomende soorten voor dit habitattype zijn de schelpkokerworm, die rond de laagwaterlijn en dieper voorkomt, en de gemshoornworm en zandvlokreeft, die in de getijdezone voorkomen. Deze soorten vormen een voedselbron voor de op de natte stranden foeragerende vogelsoorten zoals drieteenstrandloper, steenloper, bontbekplevier en strandplevier.

In het plangebied bij paal 20 komt dit habitattype alleen voor als een strook van strand voor de kust, vanaf de hoogwaterlijn tot zeewaarts het Lowest Astronomical Tide (LAT) dat onder de gemiddelde laagwaterlijn ligt. Zandplaten liggen op afstand, zoals de Razende Bol of de Hors, en komen niet voor in het plangebied.

Voor dit habitattype geldt een behoudsdoelstelling voor zowel omvang als kwaliteit leefgebied, welke waarschijnlijk behaald zal worden met het huidige beleid (Ministerie van Infrastructuur en Milieu, 2016a). Habitattype 1140B komt voor op het strand bij paal 20. Het gaat om een strook van hooguit 
enkele tientallen meters breed. Er zijn niet veel organismen in te vinden, behalve aanspoelsels en wat strandvlooien en (gemshoorn)wormen, die als voedsel voor steltlopers kunnen dienen.

\subsubsection{Habitatrichtlijnsoorten}

Onder de habitatrichtlijnsoorten van de Noordzeekustzone vallen drie soorten trekvissen en drie soorten zeezoogdieren. Alle soorten komen in het studiegebied voor, en er zijn geen aanwijzingen dat het voorkomen slechts incidenteel is.

\section{Trekvissen}

Er zijn drie soorten trekvissen aangewezen in het studiegebied Noordzeekustzone, namelijk de zeeprik, rivierprik en de fint. Deze drie soorten trekken vanuit zee de rivieren op om er te paaien. De zeeprik trekt in februari-juni de rivier op, de rivierprik in het najaar, en de fint kort voor de paaiperiode in mei-juni. Het grootste gedeelte van hun leven brengen ze door op zee, waarbij wordt vermoed dat kustwateren van groot belang zijn. Het belang van de Noordzeekustzone voor de trek van deze vissen is waarschijnlijk beperkt, maar de kennis daarover is schaars. De trek tussen zoet en zout water vindt vooral plaats in estuaria zoals het Eems-estuarium en de sluizen van de Afsluitdijk. Trekvissen komen echter ook via de zeegaten de Waddenzee binnen, zoals het Marsdiep ten zuiden van Texel en het Eierlandse gat ten noorden van Texel.

De staat van instandhouding van deze soorten is matig ongunstig vanwege de aanwezigheid van barrières om van en naar de rivieren te trekken. Voor alle drie de vissoorten gelden behoudsdoelstellingen voor omvang en kwaliteit leefgebied en uitbreiding van de populatie die waarschijnlijk gehaald gaan worden met het huidige beleid.

\section{Grijze zeehond}

De grijze zeehond is een zeezoogdier en de grootste van de twee algemeen in de Nederlandse wateren voorkomende zeehondensoorten. De dieren maken regelmatig gebruik van droogvallende platen. Meestal verblijven ze echter in de (kust)zee, waar ze foerageren op vis. Voor de voortplanting (november-februari) en verharing (maart-april) is het dier afhankelijk van permanent droogliggende platen, stranden en duinen. In tegenstelling tot die van gewone zeehonden kunnen de jongen van grijze zeehonden na de geboorte niet meteen zwemmen. Als ze in het water terecht komen, zullen ze niet meteen verdrinken maar wegdrijven en mogelijk ergens aanspoelen. Het is daarom belangrijk voor de grijze zeehond om jongen te werpen en te zogen op locaties die niet overstromen. Er zijn geen platen in de directe omgeving van het plangebied die als rust-, zoog-, voortplantingsgebied of voor de verharing van grijze zeehonden zouden kunnen worden gebruikt, en de stranden zijn daarvoor te veel verstoord door met name recreatie. Ongeveer $15 \mathrm{~km}$ ten zuiden van het plangebied ligt de Razende Bol, die wel als voortplantings- en verharingsgebied gebruikt wordt.

Grijze zeehonden komen in de kustzee van het studiegebied voor zoals beschreven in Brasseur et al. (2019). De populatie grijze zeehonden neemt nog steeds toe. Er geldt voor zowel aantallen als omvang en kwaliteit leefgebied een behoudsdoelstelling die op basis van de recente populatieontwikkeling zeker behaald zal worden.

\section{Gewone zeehond}

De gewone zeehond is de meest algemeen voorkomende zeehondensoort van het Nederlandse deel van het Noordzeegebied. De gewone zeehond brengt de meeste tijd door in zee, om te foerageren, te paren, te reizen en te slapen. Hij leeft vooral van aan de bodem gebonden vissen, waaronder veel soorten platvis. Om jongen te werpen (mei-juli), om te verharen (zomer) en om te rusten gebruiken de dieren droogvallende platen, met name in de Waddenzee. In de winterperiode trekken veel gewone zeehonden van de Waddenzee naar de Noordzee waar ze met name in het kustgebied verblijven. Er zijn geen platen in de directe omgeving van het studiegebied aanwezig die als rust-, zoog-, voortplantingsgebied of voor de verharing zouden kunnen worden gebruikt. Ook de stranden in het studiegebied worden niet gebruikt; deze worden te veel verstoord door met name recreatie. De 
gewone zeehond maakt vooral gebruik van de droogvallende platen in de Waddenzee. De Razende Bol wordt door gewone zeehonden enkel als rustgebied gebruikt.

Gewone zeehonden komen in de kustzee van het studiegebied voor zoals beschreven in Brasseur et al. (2019). De populatie gewone zeehonden neemt toe en er geldt een behoudsdoelstelling voor zowel aantallen als omvang en kwaliteit van het leefgebied dat op basis van de huidige ontwikkelingen zeker behaald zal worden.

\section{Bruinvis}

De bruinvis is een kleine walvisachtige en het talrijkste zeezoogdier van het Noordzeegebied. Zijn voedsel is gevarieerd en bestaat vooral uit (bodemlevende) vis, zoals wijting en grondels. De bruinvis is vrij schuw. De dieren leven meestal solitair of in kleine groepen. Bruinvissen worden incidenteel gezien langs de kust nabij het studiegebied (Geelhoed et al., 2020) maar leven vrij verborgen en komen hier jaarrond voor. De laagste aantallen worden gezien in de periode van mei tot en met september, en de hoogste aantallen in de periode december tot en met maart. Vanaf maart trekken ze weg uit de Noordzeekustzone.

Voor de bruinvis is er een behoudsdoelstelling voor de omvang van het leefgebied en van de populatie, en een verbeteringsdoelstelling voor de kwaliteit van het leefgebied. Voor de kwaliteit geldt dat er meer onderzoek naar de impact van visserijbijvangst en onderwatergeluid gedaan zou moeten worden om op basis daarvan geëigende maatregelen te kunnen nemen.

In het beheerplan voor de Noordzeekustzone is gesteld dat de doelstellingen met het huidige beleid naar verwachting niet behaald zullen worden.

\subsubsection{Vogelrichtlijnsoorten}

In de Noordzeekustzone zijn drie soorten broedvogels en achttien trekvogels ${ }^{6}$ uit de VR aangewezen als beschermde soort. In het rapport Natura 2000-doelen in de Noordzeekustzone. Van doelen naar opgaven voor natuurbescherming (Jak et al., 2014a, 2014b) zijn de doelstellingen, de ecologie en verspreiding van deze vogelsoorten in de Noordzeekustzone uitvoerig beschreven. Hieronder volgt een beknopte weergave.

\section{Broedvogels}

De drie broedvogelsoorten bontbekplevier, strandplevier en dwergstern broeden op de groene stranden van de Noordzeekustzone. De broedgebieden bevinden zich in de pionierzones waar de habitattypen $\mathrm{H} 2110$ (embryonale duinen), H1310 (zilte pioniersbegroeiingen) en $\mathrm{H} 1330$ (schorren en zilte graslanden) deel van uitmaken. De broedvogels zijn tevens onderdeel van de kernopgave voor de Noordzeekustzone als voortplantingshabitat en kennen een zgn. sense of urgency voor het beheer. De consequentie hiervan is dat in de komende beheerplanperiode gezorgd moet worden voor afdoende maatregelen voor het behoud van ongestoorde rustplaatsen en voortplantingshabitat voor deze broedvogels.

Op Texel broedden een tiental jaren geleden enkele paren bontbekplevieren op relatief rustige delen van het strand; met name tussen strandpaal 8 en 9, bij paal 12 en nabij de Dam bij de vuurtoren (Krol, 2010) en ook in de Slufter die slechts voor een beperkt deel, namelijk onder de hoogwaterlijn, tot de Noordzeekustzone behoort. Vanaf 2003 is dit aantal gedaald (van vier paar tot nul in 2006). Voor zowel de bontbekplevier als de strandplevier wordt het aantal broedparen in de periode 20092013 geschat op nul, maar bontbekplevieren komen soms nog wel tot broeden op Texel. In het aanwijzings-/wijzigingsbesluit wordt gesteld dat de Noordzeekustzone onvoldoende draagkracht heeft voor een zelfstandige sleutelpopulatie van de dwergstern, maar wel bijdraagt aan de draagkracht in de regio westelijk waddengebied ten behoeve van een regionale sleutelpopulatie, onder meer op de

\footnotetext{
${ }^{6}$ Een van de soorten, namelijk de bontbekplevier, is zowel broed- als trekvogel.
} 
Razende Bol en op Texel (de Hors). Deze informatie duidt erop dat het studiegebied, waarin geen groene strand-habitattypen voorkomen, niet van betekenis is voor de drie broedvogelsoorten van de Noordzeekustzone.

De bontbekplevier, strandplevier en dwergstern zijn behalve voor de Noordzeekustzone ook aangewezen voor het Natura 2000-gebied Waddenzee. Daarnaast zijn de dwergstern en de bontbekplevier aangewezen voor het Natura 2000-gebied Duinen en Lage Land Texel. De bontbekplevier broedt op Texel soms en dan met name op de Hors en in de Slufter. De strandplevier broedt op Texel alleen incidenteel op de Schorren, de Hors, in De Slufter of op de noordpunt van Texel (bij de vuurtoren of op de Volharding). In de potentiële broedgebieden op de stranden komt de strandplevier niet voor, waarschijnlijk omdat er te veel verstoring plaatsvindt. Op de Noordzeestranden van de overige Waddeneilanden neemt het aantal broedparen snel af. De bontbekplevier heeft een behoudsdoelstelling voor zowel omvang als kwaliteit van het leefgebied. De strandplevier heeft een verbeterdoelstelling voor omvang en kwaliteit van het leefgebied. Die moet gerealiseerd worden door het creëren van rust in de nabijheid van (potentiële) broedlocaties. Daarnaast moet bij het uitvoeren van zandsuppleties rekening worden gehouden met de aanwezigheid van broedlocaties. De dwergstern is naast de Natura 2000-gebieden Noordzeekustzone en Waddenzee ook aangewezen voor Duinen en Lage Land Texel. Op de Hors broedt de dwergstern sinds 1988. Aan de Sluftermonding broedden in 2020 circa zeventig paren dwergsterns, tot ze door een stormvloed werden weggespoeld. De dwergstern heeft voor alle drie Natura 2000-gebieden een uitbreidings- en verbeterdoelstelling. Die moeten gerealiseerd worden door het garanderen van rust op de bestaande broedlocatie (Razende Bol, Steenplaat) en op potentiële broedlocaties (Beheerplan Texel; Rijksdienst voor Ondernemend Nederland, 2016).

\section{Verspreiding:}

Voor de op het strand broedende vogelsoorten van het Natura 2000-gebied Noordzeekustzone is van belang na te gaan of het strand bij paal 20 van betekenis is.

- De bontbekplevier en strandplevier zijn in de afgelopen jaren in het broedseizoen niet aangetroffen in dit gebied (Beheerplan Texel; Rijksdienst voor Ondernemend Nederland, 2016; SOVON en CBS, 2005). Met uitzondering van de kust van Schiermonnikoog werden broedgevallen van de bontbekplevier en strandplevier op de stranden van de Waddeneilanden nauwelijks gemeld (zie overzicht in Jak et al. (2014a, 2014b) op basis van gegevens van SOVON. Recent zijn er echter 23/24 meldingen geweest van broedparen van de bontbekplevier op Texel. Zij bevonden zich op de brede stranden langs de westkust, de parkeerterreinen van de strandslagen als ook aan de oostkust (Vogelwerkgroep Texel, 2020). Omdat er veel recreatie is in het studiegebied en het strand niet al te breed, is de kans op aanwezigheid van broedparen van deze steltlopersoorten hier echter minimaal.

- De dichtstbijzijnde broedplekken voor dwergsterns liggen in de Slufter, op de Hors, de Razende Bol, de Volharding en de Steenplaat, respectievelijk 5, 10, 15, 12 en $15 \mathrm{~km}$ van het plangebied. De foerageerrange van broedvogels is doorgaans slechts circa $2 \mathrm{~km}$ rond het nest (Beijersbergen, 2016); dus broedvogels zullen niet in het plangebied komen foerageren. Mede door de grote hoeveelheid recreatie in het gebied is de kans op broedparen in het studiegebied minimaal, en zijn dwergsterns als broedvogel hier niet relevant; zie ook beheerplan voor Natura 2000-gebied Noordzeekustzone (Ministerie van Infrastructuur en Milieu, 2016a), Beheerplan Texel (Rijksdienst voor Ondernemend Nederland, 2016), en vogelwaarnemingen van de vogelwerkgroep Texel (www.vwgtexel.nl/waarnemingen/).

\section{Niet-broedvogels}

De Noordzeekustzone is van betekenis als rui- en/of overwinteringsgebied en rustplaats voor een groot aantal niet-broedvogels. Het gaat om vogels die voornamelijk op het open water leven en foerageren op vis (roodkeelduiker, parelduiker, aalscholver, dwergmeeuw) of tweekleppigen (eider, zwarte zee-eend, topper). Daarnaast gaat het om de bergeend en steltlopers die hun voedsel zoeken op de stranden, platen, kwelders en duinen van de Noordzeekustzone. Deze bodemdieren-etende vogels zijn steenloper, bontbekplevier en drieteenstrandloper. Andere soorten gebruiken de stranden, platen, kwelders en duinen vooral om te rusten (bonte strandloper, rosse grutto en zilverplevier). 
Kluut en wulp komen niet voor op de standen van de Noordzeekustzone. Voor de ecologische randvoorwaarden, de ruimtelijke en temporele uitwerking en de doelrealisatie zie Jak et al. (2014b).

Voor alle soorten niet-broedvogels (waaronder trekvogels) geldt behoud van het leefgebied als doelstelling. Voor de meeste soorten zal dit doel zonder aanvullende maatregelen gehaald worden (drieteenstrandloper, bonte strandloper) of waarschijnlijk gehaald worden (aalscholver, bergeend, bontbekplevier, scholekster, kluut, zilverplevier, rosse grutto, wulp, steenloper) (Ministerie van Infrastructuur en Milieu, 2016a). Voor de topper, eider en dwergmeeuw is vanwege gebrek aan kennis onduidelijk of de behoudsdoelstelling gehaald zal worden. Voor de zwarte zee-eend is gesteld dat de doelstelling waarschijnlijk niet bereikt zal worden (Ministerie van Infrastructuur en Milieu, 2016a). Voor een aantal vogelsoorten van het open water (roodkeelduiker, topper, eider en zwarte zee-eend), geldt als kernopgave behoud van de kwaliteit van het zee-ecosysteem met permanent overstroomde zandbanken (H1110B) als habitattype.

Verspreiding:

Er zijn 18 niet-broedvogels met een instandhoudingsdoelstelling voor het Natura 2000-gebied Noordzeekustzone. Al deze soorten kunnen voorkomen in het studiegebied. De Noordzeekustzone is een groot gebied, waarvan het studiegebied slechts een gering deel uitmaakt. De verspreiding van de beschermde vogelsoorten wordt o.a. gemonitord door SOVON en de verspreidingskaarten laten zien dat op Texel de meeste soorten grotere dichtheden aan de Waddenzee-zijde hebben in vergelijking met de Noordzeekustzone-zijde (Jak et al., 2014b; Beheerplan Noordzeekustzone, Ministerie van Infrastructuur en Milieu, 2016a; Beheerplan Texel, Rijksdienst voor Ondernemend Nederland, 2016; Wiersma \& Smit, 2009). De drieteenstrandloper is hierbij een uitzondering omdat deze een behoorlijk gelijkmatige dichtheid heeft over het hele Texelse Noordzeekustzone-strand van noord tot zuid, inclusief het studiegebied. Voor de meest actuele gegevens over de verspreiding en trends in aantallen van vogelsoorten wordt verwezen naar www.sovon.nl.

- Voor twaalf niet-broedvogels van de Noordzeekustzone (bergeend, topper, scholekster, kluut, bontbekplevier, zilverplevier, kanoet, drieteenstrandloper, bonte strandloper, rosse grutto, wulp, steenloper) kan op basis van het voorgaande worden vastgesteld dat deze soorten verder buiten beschouwing mogen blijven omdat hun aantallen in het studiegebied gemiddeld genomen te klein zijn om betekenis te hebben.

- De overige zes niet-broedvogelsoorten zijn wel relevant. De aalscholver komt als broedvogel voor op Texel, met drie grote kolonies (de Geul, de Schorren en de Muy) en ze foerageren massaal voor de kust van De Koog (onderdeel studiegebied). Naast de aalscholver, komen ook de roodkeelduiker, eidereend, zwarte zee-eend en dwergmeeuw op open water voor, en veelvuldig ook in het studiegebied. De parelduiker is een schaarse doortrekker in voor- en najaar in de Noordzeekustzone en dus ook in het studiegebied.

Alle voor de PB relevante soorten staan overzichtelijk vermeld in Tabel 3. 
Tabel 3 Overzicht van habitattypen en -soorten van het Natura 2000-gebied Noordzeekustzone en hun instandhoudingsdoelen. De typen en soorten die in deze PB verder buiten beschouwing blijven omdat ze er niet voorkomen of alleen in zeer kleine aantallen, zijn grijs weergegeven.

\begin{tabular}{|c|c|c|c|c|c|}
\hline $\begin{array}{l}\text { Instandhoudingsdoelen } \\
\text { Noordzeekustzone }\end{array}$ & 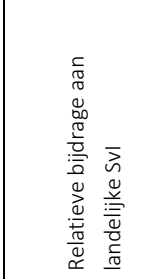 & 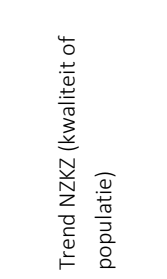 & 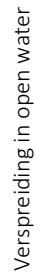 & 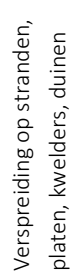 & 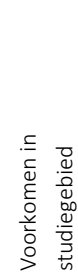 \\
\hline \multicolumn{6}{|l|}{ Habitattypen } \\
\hline H1110B - Permanent overstroomde zandbanken & ++ & Onduidelijk & $\mathrm{x}$ & & $\mathrm{x}$ \\
\hline H1140B - Slik- en zandplaten & +++ & Stabiel & & $\mathrm{x}$ & $\mathrm{x}$ \\
\hline H1310A - Zilte pionierbegroeiingen (zeekraal) & + & Stabiel & & $x$ & \\
\hline H1310B - Zilte pionierbegroeiingen (zeevetmuur) & +++ & Stabiel & & $x$ & \\
\hline H1330A - Schorren en zilte graslanden (buitendijks) & Gering & Stabiel & & $x$ & \\
\hline H2110 - Embryonale duinen & ++ & Stabiel & & $\mathrm{x}$ & \\
\hline H2190B - Vochtige duinvalleien (kalkrijk) & + & Onduidelijk & & $x$ & \\
\hline \multicolumn{6}{|l|}{ Habitatsoorten } \\
\hline H1095 - Zeeprik & + & Stabiel & $\mathrm{x}$ & & $\mathrm{v}$ \\
\hline H1099 - Rivierprik & + & Stabiel & $\mathrm{x}$ & & $\mathrm{v}$ \\
\hline H1103 - Fint & + & Stabiel & $x$ & & $\mathrm{v}$ \\
\hline H1351 - Bruinvis & + & Toenemend & $\mathrm{x}$ & & $\mathrm{x}$ \\
\hline H1364 - Grijze zeehond & + & Toenemend & $\mathrm{x}$ & $\mathrm{x}$ & $\mathrm{x}$ \\
\hline H1365 - Gewone zeehond & + & Toenemend & $\mathrm{x}$ & $\mathrm{x}$ & $\mathrm{x}$ \\
\hline \multicolumn{6}{|l|}{ Broedvogelsoorten } \\
\hline A137-Bontbekplevier & + & Onduidelijk & & $\mathrm{b}$ & \\
\hline A138 - Strandplevier & + & Afnemend & & $\mathrm{b}$ & \\
\hline A195 - Dwergstern & Gering & Afnemend & & $\mathrm{b}$ & \\
\hline \multicolumn{6}{|l|}{ Niet-broedvogelsoorten } \\
\hline A001 - Roodkeelduiker & ++ & Onduidelijk & $\mathrm{x}$ & & $\mathrm{x}$ \\
\hline A002 - Parelduiker & ++ & Onduidelijk & $\mathrm{x}$ & & $x$ \\
\hline A017 - Aalscholver & + & Onduidelijk & $x$ & & $x$ \\
\hline A048 - Bergeend & Gering & Afnemend & & $x$ & $\mathrm{v}$ \\
\hline A062-Topper & + & Afnemend & $\mathrm{x}$ & & $\mathrm{v}$ \\
\hline A063 - Eider & ++ & Afnemend & $x$ & & $x$ \\
\hline A065 - Zwarte zee-eend & +++ & Afnemend & $\mathrm{x}$ & & $\mathrm{x}$ \\
\hline A130 - Scholekster & Gering & Onduidelijk & & $x$ & $\mathrm{v}$ \\
\hline A132-Kluut & Gering & Onduidelijk & & $x$ & $\mathrm{v}$ \\
\hline A137 - Bontbekplevier & Gering & Onduidelijk & & $x$ & $\mathrm{v}$ \\
\hline A141 - Zilverplevier & + & Onduidelijk & & $x$ & $\mathrm{v}$ \\
\hline A143 - Kanoet & Gering & Onduidelijk & & $x$ & $\mathrm{v}$ \\
\hline A144 - Drieteenstrandloper & ++ & Toenemend & & $x$ & $\mathrm{v}$ \\
\hline A149 - Bonte strandloper & + & Onduidelijk & & $\mathrm{x}$ & $\mathrm{v}$ \\
\hline A157 - Rosse grutto & + & Toenemend & & $x$ & $\mathrm{v}$ \\
\hline A160 - Wulp & Gering & Stabiel & & $x$ & $\mathrm{v}$ \\
\hline A169 - Steenloper & Gering & Onduidelijk & & $x$ & $\mathrm{v}$ \\
\hline A177 - Dwergmeeuw & ++ & Fluctuerend & $\mathrm{x}$ & & $x$ \\
\hline
\end{tabular}

Legenda:

$\mathrm{b}=$ broedvogel

Relevante bijdrage van het gebied aan de landelijke Staat van Instandhouding (SvI)

\begin{tabular}{|c|c|}
\hline Gering & $<2 \%$ \\
\hline+ & $2-15 \%$ \\
\hline++ & $15 \%-50 \%$ \\
\hline+++ & $>50 \%$ \\
\hline
\end{tabular}

Voorkomen in studiegebied

\begin{tabular}{|c|l|}
\hline & Komt niet voor \\
\hline $\mathrm{v}$ & komt relatief weinig voor \\
\hline $\mathrm{x}$ & komt regelmatig en/of soms in grote aantallen voor \\
\hline
\end{tabular}




\subsection{Natura 2000-gebied Duinen en Lage Land Texel}

Het Natura 2000-gebied Duinen en Lage Land Texel beslaat een oppervlakte van 4.615 ha en wordt landschappelijk gekenmerkt door een uitgestrekt duingebied, met daarbinnen een stelsel van geulen en slenken (de Slufter) met o.a. een karakteristieke kweldervegetatie. Het noordelijk en het zuidelijk gedeelte behoorden oorspronkelijk tot twee verschillende eilanden: het oorspronkelijke Texel en Eierland. Ten westen van de stuifdijk die sinds 1629 de voormalige eilanden verbindt, ligt een oude strandvlakte met een reeks grote valleien. Het deel ten noorden van de Slufter (Eierlandse duinen) omvat oude duinen met graslanden en heiden; het zuidelijke deel is meer gevarieerd met zowel oude als jonge duingebieden. In het gebied is een grote diversiteit aan duinvalleien aanwezig, die verschillen in de mate van infiltratie dan wel kwel. Ook bevinden zich er enkele relatief grote duinplassen zoals de Horsmeertjes, de Muy en de Geul. In de Westerduinen zijn naald- en loofbossen aanwezig. Aan de zuidkant ligt een grote zandplaat, de Hors, die grotendeels deel uitmaakt van het Natura 2000-gebied Waddenzee (Ministerie van LNV, 2008).

\subsubsection{Beschermde natuurwaarden}

In het Aanwijzingsbesluit Duinen en Lage Land Texel ((Ministerie van LNV, 2008) zijn de instandhoudingsdoelstellingen beschreven. In Bijlage 2 van dit rapport zijn alle instandhoudingsdoelstellingen met hun landelijke staat van instandhouding (SvI), doelstelling oppervlakte/omvang leefgebied, doelstelling kwaliteit/kwaliteit leefgebied en doelstelling populatie/populatie omvang schematisch weergegeven.

\subsubsection{Relevante beschermde natuurwaarden}

De activiteiten voor het Slow Mill-pilotproject vinden niet plaats binnen de grenzen van het Natura 2000-gebied Duinen en Lage Land Texel. Echter via externe werking kunnen potentieel negatieve effecten van de aanleg van de kabel op het strand bij paal 20 (denk aan verstoringsfactoren als geluid en stikstofemissie) op de habitattypen en -soorten in een relatief klein deel van dat gebied niet op voorhand uitgesloten worden.

Een effect van de stikstofdepositie door graaf- en vaarwerkzaamheden in zee en op het strand (zie hoofdstuk 7) op de vegetatie in het aangrenzende Natura 2000-gebied Duinen en Lage Land Texel is niet uit te sluiten.

$\mathrm{Er}$ is nog een ander type externe werking dat relevant is om hier te beschouwen. Er zijn namelijk drie vogelsoorten die broedvogel zijn op Texel en in redelijk groten getale foerageren in het studiegebied, nl. de Noordzeekustzone. Het gaat om de kleine mantelmeeuw, grote stern en aalscholver. Voor de kleine mantelmeeuw geldt een instandhoudingsdoelstelling als broedvogel in Natura 2000-gebied Duinen en Lage Land Texel; voor de beide andere soorten niet. De grote stern heeft wel een instandhoudingsdoelstelling als broedvogel in Natura 2000-gebied Waddenzee. De Noordzeekustzone behoort tot het reguliere foerageergebied van de kleine mantelmeeuw van Texel al kunnen de aantallen sterk fluctueren, wat overigens eigen is aan meeuwen. De foerageervluchten van grote sterns kunnen zich over een aanzienlijk areaal uitstrekken. Uit onderzoek met GPS-trackers is bekend dat op Texel broedende grote sterns behalve in de Waddenzee en de zeegaten, langs de hele Noordzee-kustlijn van Texel (en noordelijker gelegen Waddeneilanden) foerageren (Baptist en Leopold 2018). Beide soorten zijn dus relevant voor deze PB.

\subsection{Andere beschermde soorten}

In hoofdstuk 2 is beschreven dat er verschillende soorten vissen, vogels, vleermuizen en zeezoogdieren op de lijsten van beschermde soorten staan (bijlage IV van de habitatrichtlijn, bijlage II van Bern en/of bijlage I van Bonn). Slechts een deel van die soorten betreft mariene soorten die relevant kunnen zijn voor de effectbeoordeling in onderhavige PB omdat ze op zee kunnen worden aangetroffen. Dan gaat het om een aantal vissen, vleermuizen, en zeezoogdieren (zie Bijlage 5). Enkele van deze soorten vissen en zeezoogdieren hebben een instandhoudingsdoelstelling voor Natura 
2000-gebied Noordzeekustzone en zijn daarom al eerder aan de orde gekomen. Daarom worden ze hier ook alleen beknopt als groepen nog een keer besproken.

\subsubsection{Vissen}

Alle van nature in Nederland voorkomende soorten vissen worden beschermd, met uitzondering van de soorten waarop de Visserijwet 1963 van toepassing is. Een groot aantal zoutwatervissen valt dus formeel onder de bijlage IV van de HR, bijlage II van Bern en/of bijlage I van Bonn (want ze zijn inheems maar ze vallen niet onder de Visserijwet), maar dit is niet als zodanig bekend gemaakt zodat deze wettelijke status niet tot nauwelijks algemeen bekend is (van Keeken et al., 2010). Er zijn zeven vissoorten die op één of meerdere van de bijlage II, III, IV van de Habitatrichtlijn staan (elft, fint, houting, rivierprik, steur, zalm, zeeprik) en bovendien regelmatig als gast of voortplanter op het Nederlands Continentaal Plat (NCP) zijn aangetroffen (zie Bijlage 5).

\subsubsection{Vogels}

Alle van nature in Nederland in het wild levende vogels, zoals bedoeld in artikel 1 van de VR worden beschermd. Dit betreft een zeer groot aantal soorten. De Noordzeekustzone is door de hoge voedselrijkdom van bijzonder belang voor veel soorten zeevogels.

\subsubsection{Zoogdieren}

Zeezoogdieren op het NCP zijn verschillende soorten zeehonden, walvissen en dolfijnen. De grijze zeehond en gewone zeehond stonden al vermeld in respectievelijk tabel 2 en 3 van de (oude) Floraen Faunawet en dat is voor beide soorten bijlage III en V van de HR. Alle walvisachtigen behoren tot de meest strikt beschermde categorie van 'tabel 3' en dat is bijlage IV van de HR (zie Bijlage 5 van deze PB). Van de zeezoogdiersoorten zijn alleen bruinvis, gewone zeehond en grijze zeehond relevant voor de Noordzeekustzone. Ook vleermuizen vallen onder die strikte bescherming van de Wnb-wet. In totaal zijn er twintig soorten vleermuizen aangemerkt. Er zijn echter geen specifieke mariene soorten vleermuizen op het NCP, maar van vijf soorten (zie Bijlage 5) is bekend dat ze wel boven zee voorkomen (Boshamer \& Bekker, 2008; Jonge Poerink et al., 2013; Lagerveld et al., 2019).

In deze PB is de effectbeschrijving (hoofdstuk 5) gericht op de soortgroepen in het algemeen (o.a. vissen, vogels, zeezoogdieren); de toepassing op relevante soorten binnen die soortgroepen vindt plaats in hoofdstuk 6. De relevante mariene soorten, vanuit de soortenbescherming van de Wnb en vanuit hun status als regelmatig waargenomen op het NCP (zie Bijlage 5) en voorkomend in het studiegebied, zijn ook soorten met een instandhoudingsdoelstelling voor het Natura 2000-gebied Noordzeekustzone. De extra aandachtsoorten zijn elft, houting, steur en zalm en vijf soorten vleermuizen. 


\section{Effectbeschrijving}

Voor een globale inschatting van de mogelijke negatieve effecten van de Slow Mill-pilotinstallatie op de relevante beschermde natuurwaarden in het studiegebied is het noodzakelijk te weten door welk type verstoringsfactoren de Slow Mill-pilotinstallatie potentiële effecten kan hebben op groepen van organismen en hoe relevant die worden geacht. Dat wordt in dit hoofdstuk beschreven. De toepassing van de vergaarde kennis op individuele soorten binnen die soortgroepen, om vast te stellen of significante effecten door de Slow Mill-installatie bij voorbaat en met zekerheid uit te sluiten zijn, wordt pas in hoofdstuk 6 gedaan.

Als eerste stap voor deze analyse worden de verstoringsfactoren (drukfactoren) geïnventariseerd die op kunnen treden door de Slow Mill-pilotinstallatie zelf en door de activiteiten die gepaard gaan met het installeren, onderhouden en ontmantelen ervan. Dit wordt gedaan in paragraaf 5.1. Als tweede stap is een literatuuronderzoek uitgevoerd waarbij informatie over de potentiële verstoringsfactoren van WECs in het algemeen is verzameld. Het resultaat daarvan en de relevantie voor de Slow Mill-pilot worden gepresenteerd in paragraaf 5.2. Deze paragraaf sluit af met een overzicht van de selectie van factoren die relevant zijn voor de Slow Mill-pilotinstallatie.

\subsection{Mogelijke verstoringsfactoren van de activiteiten}

In Tabel 4 zijn de verstoringsfactoren toegekend aan de drie fasen (bouwfase, operationele fase en ontmantelingsfase) van de voorgenomen activiteiten die eerder zijn beschreven in Tabel 1. 
Tabel 4 Kruistabel waarbij de projectactiviteiten van de Slow Mill-pilotinstallatie zijn uitgezet tegenover de geïdentificeerde verstoringsfactoren.

\begin{tabular}{|c|c|c|c|c|c|c|c|c|c|c|c|}
\hline Activiteiten & 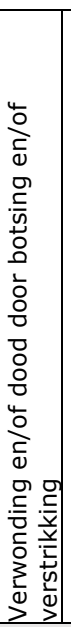 & 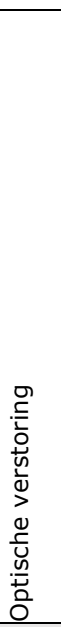 & 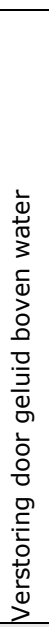 & 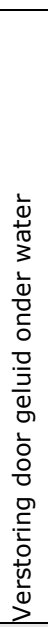 & 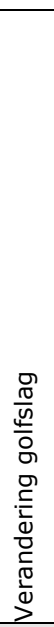 & 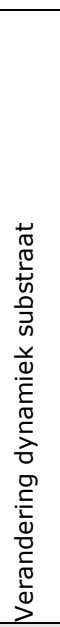 & 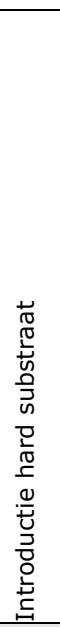 & 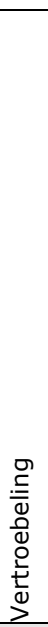 & 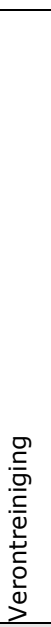 & 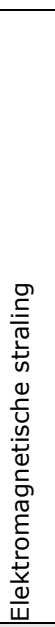 & 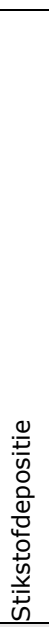 \\
\hline \multicolumn{12}{|l|}{ Bouwfase } \\
\hline Plaatsen anker & & $x$ & $x$ & $x$ & & $x$ & $x$ & $x$ & & & $x$ \\
\hline Plaatsen en ingraven elektriciteitskabel (zee) & & $x$ & $x$ & $x$ & & & & $x$ & & & $x$ \\
\hline $\begin{array}{l}\text { Plaatsen en ingraven elektriciteitskabel (strand en } \\
\text { duin) }\end{array}$ & & $x$ & $x$ & & & & & & & & $x$ \\
\hline Plaatsen Slow Mill-converter & & $x$ & $x$ & $x$ & & & $x$ & $x$ & & & $x$ \\
\hline Graafwerkzaamheden & & $\mathrm{x}$ & $x$ & & & & & & & & $x$ \\
\hline Vaarwerkzaamheden & & $x$ & $x$ & $x$ & & & & & & & $x$ \\
\hline \multicolumn{12}{|l|}{ Operationele fase } \\
\hline $\begin{array}{l}\text { Slow Mill-pilotinstallatie (anker en converter) in } \\
\text { werking }\end{array}$ & $x$ & $x$ & & $x$ & $x$ & $x$ & $x$ & & $x$ & & \\
\hline Markeringsboeien (aanwezigheid) & & $x$ & & & & & & & & & \\
\hline Elektriciteitskabel (aanwezigheid) & $\mathrm{x}$ & & & & & & & & & $x$ & \\
\hline Vaarwerkzaamheden (onderhoud en onderzoek) & & $x$ & $x$ & $x$ & & & & & & & $x$ \\
\hline \multicolumn{12}{|l|}{ Ontmantelingsfase } \\
\hline $\begin{array}{l}\text { Opruimen Slow Mill-pilotinstallatie (inclusief kabel; zie } \\
\text { hoofdstuk } 3 \text { en Tabel 1) }\end{array}$ & & $x$ & $\mathrm{x}$ & & $x$ & $x$ & & $x$ & & & \\
\hline Vaarwerkzaamheden & & $x$ & $x$ & $\mathrm{x}$ & & & & & & & $x$ \\
\hline
\end{tabular}

In elk van de drie fasen van de activiteiten kunnen er mogelijk negatieve effecten optreden op de natuurdoelen in het studiegebied. In de bouwfase treden de meeste verstoringsfactoren op. Deze zijn dan echter korter van duur dan in de operationele fase. In de ontmantelingsfase zijn de minste soorten effecten te verwachten.

De literatuur over WECs is gescreend op bevindingen over alle verstoringsfactoren uit Tabel 4, exclusief stikstofdepositie. Deze worden per verstoringsfactor beschreven in onderstaande paragrafen. Dan wordt de relevantie van de verstoringsfactoren duidelijker, alsmede welke soorten en habitattypen daarvoor gevoelig zijn.

\subsection{Mogelijke effecten o.b.v. literatuuronderzoek}

Voor de weergave van de stand van kennis omtrent effecten van WECs (en bij uitbreiding stromingsen getijdeturbines) op de natuur, en hoe die kunnen worden vermeden of verminderd, is de literatuur op deze onderwerpen onderzocht. In Google Scholar en de Scopus-database is gezocht naar technische rapporten en peer-reviewed artikelen over sterfte, habitatverlies en mitigatie van de vier soortgroepen (vogels, vleermuizen, zeezoogdieren en vissen) in relatie tot energie-infrastructuur die vergelijkbaar is met de Slow Mill-installatie. Hierbij hebben we zoektermen gebruikt die betrekking hebben op de energie-infrastructuur in combinatie met soortgroepen. Er is voornamelijk gezocht op rapporten/artikelen van na 2015. De gebruikte zoektermen werden gesteld in het Engels, zoals 'wave energy converter', 'wave stream power' en 'tidal power' in combinatie met 'habitat', 'birds',

'mammals', 'fish', 'benthos', 'environmental effect', 'ecological effect', 'mitigation', 'underwater noise', 
en variaties hierop, gebruikmakend van andere namen van soortgroepen, maar er werd ook gezocht met de naar Nederlands vertaalde termen.

In totaal hebben wij op deze manier ca. dertig referenties gevonden waarvan ongeveer de helft relevant werd bevonden voor deze PB en de beschrijving van effecten. Iedere referentie is gescreend en toegekend aan een of meer van de categorieën voor type hernieuwbare-mariene-energieconverter, type verstoringsfactor en beïnvloede soort, soortgroep of habitattype. Vervolgens is voor iedere referentie geregistreerd welk effect op de individuen, populatie of habitattype werd gevonden, of het een aangetoond of gesuggereerd effect was en, indien van toepassing, tot welke afstand vanaf de structuur het effect werd gemeten.

Golfenergieomvormers worden in de wetenschappelijke literatuur meestal wave energy converters (WECs) genoemd en deze zijn, net zoals tidal stream turbines, nog volop in ontwikkeling. Het aantal toepassingen is nog beperkt. Op dit moment zijn er nog geen full-scale operationele toepassingen van deze systemen (Copping, 2020). Er is nog weinig over eventuele effecten bekend, waardoor er ook nog een grote mate van onzekerheid is onder onderzoekers, regelgevers en stakeholders over de effecten van WECs op het ecosysteem. De kans van optreden van effecten en de mate waarin zij zich doen gelden zal afhankelijk zijn van het werkingstype (statisch of dynamisch), en de ruimtelijke schaal van een WEC (enkelvoudig of een stelsel; Copping, 2020).

De vergelijking tussen de WECs die in de literatuur beoordeeld zijn, en de Slow Mill is niet integraal en zondermeer te maken, daarvoor zijn de installaties te verschillend. Op deelaspecten is de vergelijking echter wel te maken.

\subsubsection{Botsingen en verstrikkingen}

Er zijn meerdere rapporten en artikelen die botsingen beschrijven als potentieel effect van WECs op vissen, zeezoogdieren en duikvogels. Grecian et al. (2010) merken op dat botsingen met het bovenwaterdeel van een WEC minimaal zullen zijn door het lage profiel ervan. Botsingen met het onderwaterdeel van een WEC daartegen worden wel als een reëel risico gezien. Ook Witt et al. (2012), Copping (2020) en Furness et al. (2012) geven aan dat het onderwaterdeel van een WEC een potentieel negatief effect door botsingen kan opleveren, specifiek voor duikvogels. Bij gebrek aan veldwaarnemingen en beperkt wetenschappelijk bewijs (Furness et al., 2012; Copping, 2020) is er echter enige onzekerheid over het daadwerkelijke effect.

Verstrikkingen in kabels wordt meermaals als potentieel effect beschreven voor vissen en zeezoogdieren (Witt et al., 2012) en walvissen (Copping, 2020).

Aangenomen wordt dat de verschillen tussen de in de literatuur beschouwde WEC-installaties en de Slow Mill-pilotinstallatie niet zo zeer in de bekabeling en verankering zullen zitten, immers elke drijvende WEC-installatie moet met de bodem verankerd worden. De factor botsingen en verstrikkingen is dus niet op voorhand en met zekerheid uit te sluiten.

\subsubsection{Optische verstoring}

Er zijn twee publicaties gevonden die specifiek gaan over (optische) verstoring van zeevogels door WECs. Furness et al. (2012) melden mogelijke effecten, maar Lees et al. (2016) vonden geen negatieve effecten van WECs op het habitatgebruik.

De werkzaamheden ten behoeve van de installatie van de Slow Mill (anker en converter) en het leggen van de kabel kunnen door de aanwezigheid en de bewegingen van schepen en mensen (silhouetwerking) en de daarbij geproduceerde geluiden leiden tot een tijdelijke verstoring van de in het gebied aanwezige fauna. Effecten van optische verstoring en geluid kunnen vaak niet van elkaar worden onderscheiden. Daarom verwijzen wij hierbij ook naar de volgende paragraaf over verstoring door geluid (paragraaf 5.2.3). Ook verlichting is een vorm van optische verstoring. Voor de veiligheid van de scheepvaart worden er vaarmarkeringen in de vorm van boeien geplaatst op $500 \mathrm{~m}$ van de 
Slow Mill-pilotinstallatie. In de overwegend donkere Noordzeekustzone kan dit licht 's nachts verstoring veroorzaken voor vogels, zeezoogdieren en vissen.

De bouw- en ontmantelingswerkzaamheden zullen een kortstondige verstoring geven. De installatie zelf kan vanaf plaatsing wel gedurende de gehele testperiode en exploitatiefase optische verstoring veroorzaken. De beschermde zeehonden en vogelsoorten zijn gevoelig voor verstoring door de bewegingen van mensen en materieel. Tijdens deze werkzaamheden kunnen aanwezige dieren binnen een soort-specifieke verstoringafstand door bewegingen tijdelijk verstoord worden en vervolgens het plangebied en de omgeving (dus het studiegebied) voor een langere of kortere periode mijden. $\mathrm{Na}$ afloop van de werkzaamheden stopt de verstoring en kunnen de dieren het gebied weer gebruiken. Hierbij dient opgemerkt te worden dat er ook gewenning kan optreden, waardoor sommige individuen na verloop van tijd gebiedsvreemde objecten dichter gaan benaderen. Gewenning is geconstateerd bij zeehonden en sommige vogelsoorten, maar voor WECs zijn, voor zover wij weten, nog geen waarnemingen van gewenning gerapporteerd.

Verstoring van zeezoogdieren door bewegingen van schepen varieert per type en grootte van het schip, waarbij een maximale reikwijdte van $700 \mathrm{~m}$ kan worden aangehouden volgens Pondera Consult (2018). Dat geldt ook voor geluid boven water; zie 5.2.3.

Vogelsoorten van open water zijn vaak gevoeliger voor verstoring dan de vogelsoorten van stranden, duinen en droogvallende platen. In Tabel 5 is een overzicht gemaakt van de vluchtafstanden van relevante vogelsoorten. De meest verstoringsgevoelige vogelsoorten zijn zwarte zee-eend en roodkeelduiker/parelduiker, met vluchtafstanden van respectievelijk $1500 \mathrm{~m}$ en 500-2000 m (Krijgsveld et al., 2008). In de regel wordt voor verstoring van zeevogels een maximale reikwijdte van $1500 \mathrm{~m}$ aangehouden (Pondera Consult, 2018). Vogelsoorten op droge gebieden (strand e.d.) worden verstoord binnen een afstand van maximaal $300 \mathrm{~m}$ van de bron (mensen of gebiedsvreemde objecten) en vluchten binnen een afstand van maximaal $125 \mathrm{~m}$. Dit is afhankelijk van de vogelsoort (Krijgsveld et al., 2008, Jongbloed et al., 2011).

Tabel 5 Verstoringsgevoeligheid van vogels die foerageren en rusten in het studiegebied. De aangegeven afstanden zijn gebaseerd op Krijgsveld et al. (2008). Nb = niet bekend.

\begin{tabular}{|l|c|c|}
\hline Instandhoudingsdoelstelling & $\begin{array}{c}\text { Vluchtafstand } \\
\mathbf{( m )}\end{array}$ & $\begin{array}{c}\text { Alertafstand } \\
\mathbf{( m )}\end{array}$ \\
\hline A001 - Roodkeelduiker & & $\mathrm{nb}$ \\
\hline A002 - Parelduiker & $500-2000$ & $\mathrm{nb}$ \\
\hline A017 - Aalscholver & $500-2000$ & 150 \\
\hline A048 - Bergeend & 75 & $\mathrm{nb}$ \\
\hline A062 - Topper & $102-380$ & $\mathrm{nb}$ \\
\hline A063 - Eider & 500 & $\mathrm{nb}$ \\
\hline A065 - Zwarte zee-eend & $\mathrm{nb}$ & $\mathrm{nb}$ \\
\hline A130 - Scholekster & 1500 & 175 \\
\hline A132 - Kluut & 100 & 250 \\
\hline A137 - Bontbekplevier & 75 & 175 \\
\hline A141 - Zilverplevier & 100 & 175 \\
\hline A143 - Kanoet & 100 & 300 \\
\hline A144 - Drieteenstrandloper & 125 & 300 \\
\hline A149 - Bonte strandloper & 125 & 300 \\
\hline A157 - Rosse grutto & 125 & $\mathrm{nb}$ \\
\hline A160 - Wulp & 125 & 300 \\
\hline A169 - Steenloper & $\mathrm{nb}$ & \\
\hline A177 - Dwergmeeuw & & \\
\hline
\end{tabular}


Het grootste deel van het traject van de aan te leggen elektriciteitskabel voor de Slow Millpilotinstallatie bevindt zich op een dermate grote afstand ( $>300 \mathrm{~m}$ ) tot de grens van het Natura 2000-gebied Duinen en Lage Land Texel (zie paragraaf 3.1 en Figuur 9) dat vogels die zich in dat gebied bevinden, niet of niet noemenswaardig worden verstoord door de aanwezigheid van machines en de mensen die de elektriciteitskabel aanleggen. Een deel van het kabeltraject loopt echter vlak langs de grens van Natura 2000-gebied Duinen en Lage Land Texel. Dat betreft het traject langs/onder de Badweg naar de parkeerplaats (De Koog) over een afstand van circa $200 \mathrm{~m}$ of over een afstand van circa $400 \mathrm{~m}$ naar de bebouwde kom Figuur 9). De Badweg is een strandopgang en wordt regelmatig druk bezocht door recreanten. De verwachting is dat de werkzaamheden voor de aanleg van de kabel geen extra verstoring van vogels zullen veroorzaken.

Op basis van de literatuur concluderen wij dat optische verstoring van vogels en zeezoogdieren niet kan worden uitgesloten voor de activiteiten in de bouwfase (plaatsen van anker, elektriciteitskabel en de Slow Mill-converter) alsmede in de operationele fase van de Slow Mill-pilotinstallatie.

\subsubsection{Verstoring door geluid (boven water)}

Er is één studie gevonden in de literatuur die specifiek ingaat op de mogelijke effecten van de WECs via bovenwatergeluid, namelijk Witt et al. (2012). Hierin wordt vermeld dat negatieve effecten door geluid (boven en onder water) tijdens de bouwfase van WECs op zeezoogdieren, vogels en vissen mogelijk zijn.

Tijdens het plaatsen van het anker, de elektriciteitskabel (met bijkomende graafwerkzaamheden) het plaatsen van de converter, en het onderhouden en later weer ontmantelen van de Slow Millpilotinstallatie, inclusief alle daarmee gepaard gaande vaarwerkzaamheden, vindt verstoring door geluid boven water plaats. Vogelsoorten zullen gevoelig zijn voor de verstoring door het geluid van de schepen en de graafmachine. Deze verstoringen treden meerdere malen op, in de periode maart-mei (zie Tabel 1), maar zijn niet van lange of permanente duur. Het inregelen van de installatie en latere onderhoudswerkzaamheden vinden gespreid plaats. Als de werkzaamheden gestopt zijn, stopt ook de geluidsverstoring en kunnen vogels en andere dieren het gebied weer gebruiken.

Onderdelen in de horizontale drijver waar de generator zich bevindt, kunnen ook geluiden maken wanneer de installatie in werking is, dus permanent, maar het is niet te verwachten dat die geluiden buiten de behuizing treden.

Wij concluderen dat effecten van bovenwatergeluid in alle fases mogelijk zijn, met name in de bouwfase De verwachting is dat deze effecten niet groot zijn en stoppen zodra de werkzaamheden beëindigd zijn.

\subsubsection{Verstoring door geluid (onder water)}

Er is een aantal publicaties beschikbaar over de emissie van onderwatergeluid van WECs en de mogelijke effecten daarvan op mariene vissen en zoogdieren (Probert \& Mitchell (1983, Witt et al. (2012), Tougaard (2015), Buscaino et al. (2019), Haikonen et al. (2013), Copping et al. (2014), Copping(2020). Het beeld dat hieruit ontstaat is gevarieerd, namelijk van waarschijnlijk geen effect tot wel een effect van onderwatergeluid op vissen en zoogdieren, maar het is duidelijk dat er nog veel onbekend is en onderzocht zou moeten worden om hierover harde uitspraken te kunnen doen. De ernst van eventuele effecten is voor een belangrijk deel afhankelijk van het type constructie en de mate waarin onderwatergeluid wordt geproduceerd.

Geluid wordt geproduceerd door het raken van mechanische/geveerde eindstops. De Slow Millpilotinstallatie heeft echter een hydraulische cilinder waar hydraulische eindbuffers in zitten waardoor er geen mechanische klappen kunnen ontstaan. De lamellen in het bovenste deel van Slow Mill waarover de waterstroom wordt geleid, hebben een vleugelprofiel en zijn niet beweeglijk. Het draaipunt op het anker zal bij voldoende onderhoud geen geluid door mechanische wrijving opleveren. Andere bronnen van geluidsvorming zijn niet aannemelijk. Metingen ter plaatse naar de 
geluidsproductie van de Slow Mill-pilotinstallatie onder en boven water zouden duidelijkheid kunnen geven.

In de voorgaande paragrafen over optische verstoring en bovenwatergeluid is al vermeld dat verschillende bouw-, onderhouds- en ontmantelingsactiviteiten rond de Slow Mill-pilotinstallatie ook onderwatergeluid produceren. Bij het plaatsen van het anker, de elektriciteitskabel en de converter, en het onderhouden van de Slow Mill-installatie vindt verstoring door onderwatergeluid van werkschepen plaats, en mogelijk door de toegepaste antifouling-technieken (zie paragraaf 3.2). Zeezoogdieren en vissen zijn gevoelig voor verstoring door onderwatergeluid, kunnen ervan schrikken. Er zijn geen algemeen geaccepteerde drempelwaarden voor verstoring van zeezoogdieren, waarbij dieren het gebied als gevolg van (continu) onderwatergeluid veroorzaakt door schepen verlaten of vermijden (Pondera Consult, 2018). De maximale verstoringsafstand van continu onderwatergeluid voor zeezoogdieren is kleiner dan $5 \mathrm{~km}$, waardoor de maximale reikwijdte van $5 \mathrm{~km}$ als worst casescenario voor de Slow Mill-pilotinstallatie en de benodigde werkschepen kan worden aangehouden. De verstoring door de werkschepen is van korte duur, en de zeezoogdieren en vissen kunnen na de korte verstoring terugkeren in het niet langer verstoorde gebied. Onze verwachting is dat het onderwatergeluid van de activiteiten voor installatie, onderhoud en ontmanteling van de Slow Mill-pilotinstallatie alleen tot tijdelijke effecten zal leiden die verwaarloosbaar zullen zijn vanwege de aanwezigheid van bestaande activiteiten in het studiegebied (denk aan de nabije scheepvaartroute en visserij). De belasting door continu-geluid is echter niet goed in te schatten en daardoor niet uit te sluiten.

\subsubsection{Verandering golfslag}

Er zijn meerdere studies gedaan naar de veranderingen van hydrodynamische processen door WECs (O'Brien et al., 2015; Copping et al., 2014; Contardo, 2018; Tomey-Bozo et al.,2019). Aangenomen wordt dat het effect van verandering van de golfslag bij kleine aantallen Marine Renewable Energy (MRE)-installations (NL: hernieuwbare mariene energie installaties) minimaal is of zelfs wegvalt binnen de natuurlijke variatie, maar meetwaarden uit het veld zijn nodig bij toepassing van grootschalige sets aan MREs om dit te onderbouwen (Copping, 2020).

Er zijn twee publicaties gevonden waarin het effect van golfslagverandering door WECs op het ecosysteem is onderzocht, namelijk indirecte effecten op zeevogels (Grecian et al. (2010) en een verandering van fytoplanktonsamenstelling (Witt et al. (2012).

In de operationele fase zal de golfslag achter de Slow Mill-pilotinstallatie gereduceerd zijn, maar de mate waarin is niet bekend. Gereduceerde golfslag en waterstroming zorgen voor een verminderde erosie en verhoogde sedimentatie in het gebied achter de pilotinstallatie. Of en tot op welke afstand dit sedimentatie-effect zou kunnen optreden is niet bekend ${ }^{7}$. Daarnaast zal door de verminderde golfslag de aanvoer van nutriënten en planktonrijk water verminderen, wat lokaal een negatief effect kan hebben op de biodiversiteit en beschikbaarheid van voedsel voor vissen, zeezoogdieren en vogels. De Slow Mill-locatie op $4 \mathrm{~km}$ voor de kust van Texel wordt echter gekenmerkt door behoorlijk extreme condities met tijdelijk hoge stroomsnelheden en veel golfwerking (Witbaard, 2020). Een enkele converter zal daarom geen van beide effecten op de omgeving hebben.

\subsubsection{Verandering dynamiek substraat}

In de literatuur is aan de verandering van de dynamiek van substraat door WECs enige aandacht besteed, maar er is gebrek aan onderzoeksgegevens. Sommige studies vonden een duidelijk effect (Probert \& Mitchell, 1983), andere weinig effect (Langhammer, 2010) of een effect dat varieerde van klein tot groot, afhankelijk van de omvang van de WEC of het veld aan WECs (Copping et al., 2014; Copping, 2020).

Het plaatsen van de Slow Mill-converter en het bijbehorende anker op de zeebodem verandert de waterstroming en de sedimentatie en dus de lokale dynamiek van het substraat. De mate van de

\footnotetext{
${ }^{7}$ Als er al een effect van uitgaat, zal dat waarschijnlijk alleen bij een opstelling van meerdere converters optreden, en zou deze grotere installatie dan in theorie voor kustbescherming kunnen zorgen; voor deze PB (installatie van één converter) verder niet relevant.
} 
verandering zal afhankelijk zijn van meerdere factoren, zoals de bestaande omstandigheden en het type en de omvang van de WEC of het veld van WECs. De Slow Mill-installatie staat relatief dicht bij de kust en op geringe waterdiepte waar zeer energierijke condities overheersen. Het is echter niet te verwachten dat een enkel Slow Mill-systeem (gesuspendeerd energie-absorberend systeem en het betonnen anker) de hydrografie op grote schaal voor de kust van Texel zal veranderen ${ }^{8}$.

\subsubsection{Introductie hard substraat}

In de literatuur zijn een aantal publicaties beschikbaar over het potentiële effect van de introductie van hard substraat door WECs en deze melden vaak positieve effecten en soms negatieve effecten, of een combinatie van beide (Grecian et al., 2010); Probert \& Mitchell, 1983; , Witt et al., 2012; Nall et al., 2017; Haikonen et al., 2013; Copping, 2020).

Met het plaatsen van de Slow Mill-pilotinstallatie en het bijbehorende anker op de zeebodem wordt er een nieuw hard substraat gecreëerd wat voor kunstmatige verhoging van de lokale biodiversiteit kan zorgen. Dit zal vissen aantrekken en daarmee in potentie ook zeezoogdieren en (duik)vogels, wat een positief effect op de biodiversiteit betekent. Echter, tegelijkertijd gaat er een oppervlakte verloren van het bestaande habitattype 'permanent overstroomde zandbanken' (H1110B) dat bestaat uit zachte zeebodem. Tevens kan er een verhoogd risico op botsingen van vissen en zeezoogdieren en duikende zeevogels optreden met de WEC. Vertroebeling en verontreiniging zijn andere verstoringsfactoren die gepaard gaan met de introductie van de structuren. Deze verstoringsfactoren worden in de overige paragrafen behandeld. Daarnaast wordt een nieuw habitattype geïntroduceerd dat niet binnen het beheer van de Noordzeekustzone hoort. Men dient te beseffen dat het anker bij het plaatsen van de Slow Mill-converter omhooggehaald moet worden wat de ontstane biodiversiteit negatief kan aantasten. Aan het eind van de pilot wordt het anker weer verwijderd en dit nieuw ontstane habitat verdwijnt dan geheel en de dynamiek zal opnieuw drastisch veranderen (terugkeren naar de situatie van voor de plaatsing). Een permanent park van Slow Mill-installaties met hun ankers kan wel een permanent nieuw habitat met verhoogde biodiversiteit creëren. Een andere verandering van substraat kan ontstaan doordat er binnen een veiligheidszone van circa $30 \mathrm{~m}$ rond de Slow Mill geen andere activiteiten mogen plaatsvinden. In het geval dat bodem-beroerende visserij wegvalt, kan dat mogelijk een positief effect hebben op de lokale biodiversiteit. Overigens kan het netto-effect binnen de veiligheidszone negatief zijn door de aanwezigheid van negatieve effecten van andere verstoringsfactoren zoals zojuist beschreven. Een voorspelling van het netto-effect is moeilijk te geven. Het gebied waarop dit effect betrekking heeft is echter zeer klein.

Witbaard (2020) hebben experimenteel onderzoek gedaan naar het effect van het plaatsen van hard substraat op de biodiversiteit op de locatie voor de Slow Mill-pilotinstallatie die op $4 \mathrm{~km}$ ten westen van Texel ligt op een waterdiepte van 12-14 m. Zij hebben bemonsteringen gedaan van de bodemfauna en de aangroei op een meetframe. Hun conclusies waren (geciteerd):

- $\quad$ "De Slow Mill locatie wordt gekenmerkt door een fauna die van nature arm aan soorten is die in lage dichtheden voorkomen.

- De dichtheden en het aantal aangetroffen soorten in de natuurlijke zandbodem is sterk seizoens afhankelijk.

- Het kortstondig (3 maanden) plaatsen van een hard substraat object in deze ondiepe kustzone leidt tot vestiging van 18 soorten die niet in de zandbodem worden gevonden. Afhankelijk van het seizoen leidt dat tot een verhoging van de lokale biodiversiteit van tussen de 36 en $51 \%$.

- De dichtheden organismen zijn op het hardsubstraat $400 \%$ hoger dan in de natuurlijke zandbodem.

- Bij grootschalige plaatsing van hardsubstraat in deze ondiepe kustzone valt op grond van deze resultaten te verwachten dat op lokale schaal biodiversiteit en secundaire productie toenemen."

\footnotetext{
${ }^{8}$ Bij een grootschalige uitrol van Slow Mill-energiesystemen zouden door golfdemping en remming van de stroming, sedimentatie en re-suspensiekarakteristieken duidelijke effecten kunnen optreden (Witbaard, 2020). Een schaaleffect is aannemelijk; de gevoeligheid ervan is echter niet bekend.
} 
Witbaard (2020) verwacht dat de ontwikkeling en het eindstadium van de hardsubstraatgemeenschap op de Slow Mill-locatie sterk door de extreme abiotische condities met tijdelijk hoge stroomsnelheden en veel golfwerking zal worden beïnvloed, waardoor de aangroei relatief arm aan soorten zal blijven, alhoewel de totale biodiversiteit (zacht en hard substraat) dus wel aanmerkelijk toenam.

\subsubsection{Vertroebeling}

Specifiek met betrekking tot WECs is de publicatie van Witt et al. (2012) van belang, waarin wordt beschreven dat door vertroebeling, net als bij de soms ook optredende golfslagvermindering en verstoring van het sediment, er veranderingen in de samenstelling en de dichtheid van plankton kunnen optreden.

Bij het plaatsen van het anker, de elektriciteitskabel en het plaatsen en ontmantelen van de Slow Millinstallatie zal er vertroebeling van het water ontstaan. Vertroebeling betreft een toename van gesuspendeerd materiaal in de waterkolom. Een verhoogde troebelheid kan effect hebben op de primaire productie (algenbloei), zeker in de periode van de bouwfase die midden in de voorjaarsbloei van fytoplankton valt. Daarnaast kan vermindering van zicht voor zichtjagers veroorzaakt worden en kan de vertroebeling leiden tot verstopping van ademhalingsorganen en het verzamelen van voedsel van filter feeders verstoren. Desondanks is de vertroebeling zeer lokaal en van beperkte tijdsduur en zijn dergelijke effecten (naar wij weten) nog nooit in het veld gemeten. Mede vanwege de hoge hydrodynamiek ter plaatse is het slechts een beperkte extra vertroebeling. Wij concluderen dat een eventueel negatief effect dat van vertroebeling uitgaat altijd verwaarloosbaar zal zijn.

\subsubsection{Verontreiniging (toxische stoffen)}

Witt et al. (2012) noemden de mogelijkheid dat toxische antifouling op WECs de mortaliteit van plankton kunnen verhogen. De Slow Mill-pilotinstallatie wordt niet uitgerust met een aangroeiremmende coating, ook zgn. zelfslijpende antifouling wordt niet toegepast, wel zal gekozen worden uit verschillende typen antifouling-technieken die voor de start van het project getest zullen zijn (zie paragraaf 3.2). De wrapping-folie en micro-haartjes (finsulate) kunnen loskomen en zijn een vorm van fysiek afval (litter). Op basis van dat laatste concluderen wij dat negatieve effecten van verontreiniging niet kunnen worden uitgesloten, maar bij één installatie beperkt zullen zijn.

\subsubsection{Elektromagnetische straling}

De effecten van elektromagnetische straling door de bekabeling van WECs is nog niet voldoende bekend of ingeschat (Witt et al., 2012; Haikonen et al., 2013), terwijl Copping (2020) concludeert dat effecten van elektromagnetische straling (door elektrakabels) van de huidige kleine en enkelvoudige WECs op benthische marine organismen waarschijnlijk minimaal zullen zijn.

De Slow Mill-pilotinstallatie heeft maar één kabel wat in vergelijking met bv. windmolenparken (Witt et al., 2012) weinig is. Kabels produceren een elektromagnetisch veld dat mogelijk negatieve effecten op vissen en zeezoogdieren kan veroorzaken, afhankelijk van de sterkte van dat elektromagnetische veld. Het spanningsniveau van de transportkabel van de Slow Mill-pilotinstallatie is $10 \mathrm{kV}$. Dit is veel lager dan het spanningsniveau van offshore-windparken. Het Transformatiesysteem Op Zee Hollandse Kust Zuid (TOZ-HKZ) bv. heeft vanaf de platforms twee 220 kV-kabels naar de kust (Pondera Consult, 2018). De maximale reikwijdte van de TOZ-HKZ kabel wordt als minimaal (enkele meters tot $15 \mathrm{~m}$ ) ingeschat (Pondera Consult, 2018).

Omdat er voor deze verstoringsfactor een grote kennislacune is, kunnen potentieel negatieve effecten van elektromagnetische straling door de elektriciteitskabel van de Slow Mill-pilotinstallatie niet op voorhand worden uitgesloten.

\subsubsection{Stikstofdepositie}

Bij het varen tussen de locatie voor de Slow Mill-pilotinstallatie en de haven van Den Helder en het ingraven van de kabel op het strand en in de duinen zal emissie van stikstof plaatsvinden door de 
verbrandingsmotoren van het ingezette materieel. Het is aannemelijk dat er enige mate van depositie van stikstof zal optreden op de vegetatie in de nabijheid, waaronder de habitattypen van Natura 2000gebied Duinen en Lage Land Texel. De stikstofdepositie is gekwantificeerd met behulp van AERIUStool in hoofdstuk 7.

\subsubsection{Positieve effecten}

Er kunnen naast de potentieel negatieve effecten ook potentieel positieve effecten van de Slow Millpilotinstallatie op natuurwaarden optreden. In de literatuur zijn vermeldingen over (mogelijk) positieve effecten van WECs gevonden. Sommige daarvan zijn in de voorgaande paragrafen al kort beschreven, omdat positieve en negatieve effecten van WECs tegelijk kunnen komen. De potentieel positieve effecten van WECs worden in deze paragraaf gecompileerd.

De positieve effecten hangen samen met de introductie van hard substraat in een omgeving waar zeer weinig natuurlijk (en onnatuurlijk) hard substraat aanwezig is. Dit gaat namelijk gepaard met:

- een toename van het aantal benthossoorten die leven op het artificieel substraat (Nall et al., 2017; Copping, 2020);

- $\quad$ een grotere voedselbeschikbaarheid voor vissen, duikende vogels, zeezoogdieren (Probert \& Mitchell, 1983; Witt et al., 2012);

- een plaatselijke toename van soorten vanwege rustplaatsen voor vogels (Grecian et al., 2010);

- $\quad$ en gekoppeld aan bovengenoemde veranderingen: een plaatselijke toename van de biodiversiteit (Nall et al., 2017; Witt et al., 2012; Haikonen et al., 2013; Witbaard, 2020). De ontwikkeling en het eindstadium van de hardsubstraat gemeenschap op de Slow Mill-locatie zal sterk door de extreme abiotische condities (tijdelijk hoge stroomsnelheden en veel golfwerking) worden beperkt, alhoewel de totale biodiversiteit (zacht en hard substraat) nog wel aanmerkelijk kan toenemen (Witbaard, 2020).

Een positief neveneffect van de installatie van WECs is het weren van andere activiteiten in een veiligheidszone, bv. de verwijdering van bodem-beroerende visserij uit het gebied waardoor de zeebodem zich kan herstellen van deze activiteit (Witt et al., 2012).

In de bredere context is de opmerking van Copping et al. (2014) interessant dat bij de overwegingen van de (milieu)effecten van hernieuwbare energiewinning uit de zee het ook belangrijk is om te realiseren dat alle vormen van energieproductie gepaard gaan met milieukosten en deze dus met hun directe en indirecte milieueffecten tegen elkaar kunnen worden afgewogen. Bij toetsing aan de Wnb die in deze PB wordt uitgevoerd, gaat het echter alleen om de mogelijke negatieve effecten op de instandhoudingsdoelstellingen en niet om mogelijke positieve effecten op (andere) natuurwaarden of milieuaspecten.

\subsubsection{Overzicht van de bevindingen van de verstoringsfactoren}

Op basis van de hierboven geschetste bevindingen worden in deze paragraaf twee overzichtstabellen gepresenteerd. In Tabel 6 wordt een overzicht gegeven van de verstoringsfactoren die relevant zijn vanwege de mogelijke negatieve effecten van de Slow Mill-pilotinstallatie op natuurdoelen van de Noordzeekustzone. Deze bevindingen worden in hoofdstuk 6 toegepast op de afzonderlijkje soorten en habitattypen die relevant zijn voor het onderhavige studiegebied. In een tweede overzicht (Tabel 7) zijn dezelfde bevindingen voor de verschillende activiteiten en fases van het Slow Mill-pilotproject in beeld gebracht. 
Tabel 6 Overzicht van de conclusies over potentiële effecten van verstoringsfactoren van golfslagconvertoren (WECs) gebaseerd op literatuuronderzoek.

\begin{tabular}{|c|c|c|c|c|c|c|c|c|c|c|}
\hline $\begin{array}{l}\text { Soortgroep/ } \\
\text { Habitat }\end{array}$ & 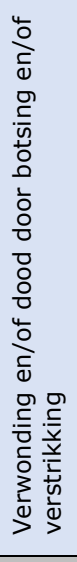 & 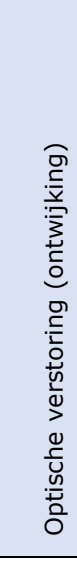 & 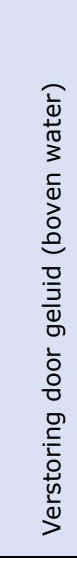 & 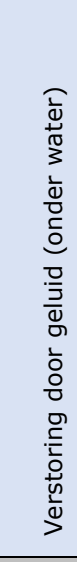 & 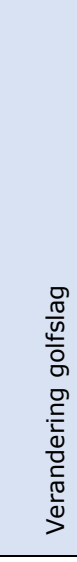 & 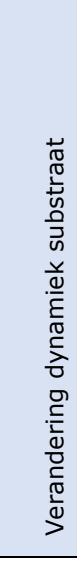 & 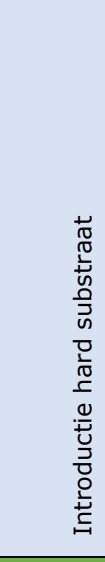 & 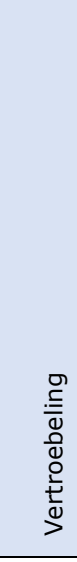 & 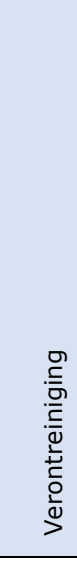 & 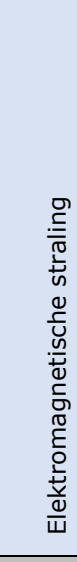 \\
\hline Vissen & $\mathrm{P}$ & & & $\mathrm{P}$ & & & Pos & & & $\mathrm{P}$ \\
\hline Zeezoogdieren & $\mathrm{P}$ & & & $\mathrm{P}$ & & & Pos & & & $\mathrm{P}$ \\
\hline Zeevogels & $\mathrm{P}$ & $\mathrm{P}$ & $\mathrm{P}$ & & $\mathrm{P}$ & & Pos & & & \\
\hline Benthos & & & & & & & $\mathrm{P}$ & & & $\mathrm{P}$ \\
\hline Epibenthos & & & & & & & Pos & & & \\
\hline Habitat & & & & & $\mathrm{P}$ & $\mathrm{P}$ & Pos/P & $\mathrm{P}$ & $\mathrm{P}$ & \\
\hline Biodiversiteit & & & & & & $\mathrm{P}$ & Pos & & & \\
\hline
\end{tabular}

\begin{tabular}{|c|l|}
\hline$P$ & Potentieel negatief effect \\
\hline Pos & Potentieel positief effect \\
\hline PoS/P & Potentieel positief of negatief effect \\
\hline & Geen potentieel effect \\
\hline
\end{tabular}


Tabel 7 Overzicht van de verstoringsfactoren die zich in de onderscheiden fases per activiteit van de Slow Mill-pilotinstallatie kunnen doen gelden. Aangegeven is de overlap in tijd en ruimte met aanwezige beschermde natuurwaarden en de verwachting omtrent een effect.

\begin{tabular}{|c|c|c|c|c|c|c|c|c|c|c|c|}
\hline Activiteiten & 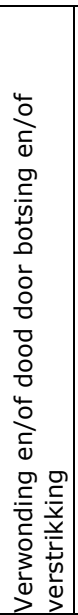 & 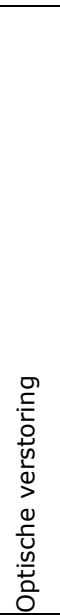 & 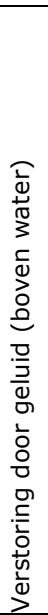 & 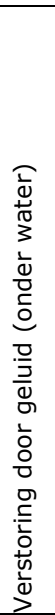 & 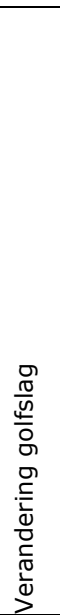 & 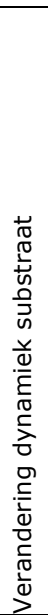 & 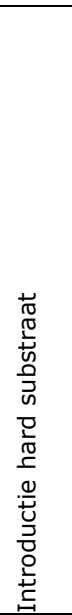 & 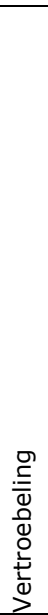 & 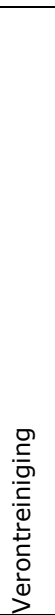 & 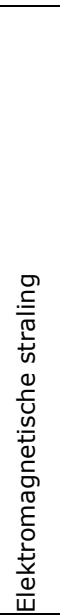 & 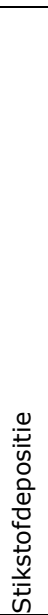 \\
\hline \multicolumn{12}{|l|}{ Bouwfase } \\
\hline Plaatsen elektriciteitskabel (zee) & & $P$ & $\mathrm{P}$ & $P$ & & & & & & & $\mathrm{P}$ \\
\hline Plaatsen elektriciteitskabel (strand en duin) & & & & & & & & & & & $\mathrm{P}$ \\
\hline Plaatsen anker & & $P$ & $P$ & & & & \begin{tabular}{|c} 
Pos/ \\
P
\end{tabular} & & & & P \\
\hline Plaatsen van Slow Mill-converter & & $P$ & $P$ & & & & \begin{tabular}{|c} 
Pos/ \\
P
\end{tabular} & & & & $\mathrm{P}$ \\
\hline Graafwerkzaamheden & & & & & & & & & & & $\mathrm{P}$ \\
\hline Vaarwerkzaamheden & & & & & & & & & & & $P$ \\
\hline \multicolumn{12}{|l|}{ Operationele fase } \\
\hline Slow Mill-converter in werking & $P$ & $\mathrm{P}$ & & $\mathrm{P}$ & & & $\begin{array}{c}\text { Pos/ } \\
\text { P }\end{array}$ & & $\mathrm{P}$ & & \\
\hline \multicolumn{12}{|l|}{ Markeringsboeien } \\
\hline Elektriciteitskabel & & & & & & & & & & $P$ & \\
\hline Vaarwerkzaamheden (onderhoud) & & & & & & & & & & & $\mathrm{P}$ \\
\hline \multicolumn{12}{|l|}{ Ontmanteling fase } \\
\hline \multicolumn{12}{|c|}{ Opruimen Slow Mill-installatie incl. anker en kabel } \\
\hline Vaarwerkzaamheden & & & & & & & & & & & $p$ \\
\hline
\end{tabular}

Legenda:

\begin{tabular}{|c|l|}
\hline & Activiteit heeft geen overlap in ruimte en tijd met een beschermde natuurwaarde (habitattype of de soort) \\
\hline & $\begin{array}{l}\text { Activiteit heeft wel overlap in ruimte en tijd met een beschermde natuurwaarde (habitattype of de soort), maar } \\
\text { een effect is niet aannemelijk }\end{array}$ \\
\hline P & $\begin{array}{l}\text { Activiteit heeft wel overlap in ruimte en tijd met een beschermde natuurwaarde (habitattype of de soort), en } \\
\text { daarbij mogelijk een effect }\end{array}$ \\
\hline $\begin{array}{c}\text { Pos/ } \\
\text { P }\end{array}$ & $\begin{array}{l}\text { Activiteit heeft wel overlap in ruimte en tijd met een beschermde natuurwaarde (habitattype of de soort), en } \\
\text { daarbij mogelijk een effect dat positief of negatief kan zijn }\end{array}$ \\
\hline
\end{tabular}




\section{Effectbeoordeling}

In het voorgaande hoofdstuk is de relevante literatuur gescreend om de potentiële verstoringsfactoren van WECs met hun eventuele effecten op natuurwaarden te kennen. In dit hoofdstuk worden de potentiële effecten van de Slow Mill-pilotinstallatie beoordeeld in het licht van de Wnb, de Natura 2000-instandhoudingsdoelstellingen. Daarbij wordt eerst de ruimtelijke en temporele aanwezigheid van de habitattypen en soorten nader in relatie tot de activiteiten van de Slow Mill-pilotinstallatie gebracht.

De effectbeoordeling is per soortgroep uitgevoerd in twee stappen. De eerste stap is feitelijk reeds uitgevoerd in de voortoets (Jongbloed et al., 2020). De resultaten daarvan zijn dus onderdeel van deze PB. Het betreft een globale beoordeling op basis van voor de hand liggende informatie. In de tweede stap worden de soorten en habitattypen waarvoor significante effecten op de instandhoudingsdoelstellingen niet konden worden uitgesloten in de voortoets, nader getoetst. Daarvoor wordt alle beschikbare informatie verzameld over de mogelijke gevoeligheid voor de voorgenomen activiteiten in afhankelijkheid van de verspreiding van de onderhavige soorten in het studiegebied en het betreffende Natura 2000-gebied, teneinde de te verwachten effecten op de relevante instandhoudingsdoelstellingen op basis van de beste beschikbare kennis in te kunnen schatten. Deze tweede stap is een gedetailleerde beoordeling. Het resultaat van de globale beoordeling uit de voortoets is opgenomen in Bijlage 6. De globale en gedetailleerde beoordeling vormen samen het eindresultaat van deze PB (Tabel 16).

Effecten op de instandhoudingsdoelen van Natura 2000-gebied Duinen en Lage Land Texel worden uitgesloten geacht omdat de projectactiviteiten zich buiten de begrenzing van dat gebied bevinden en de werking van de verstoringsfactoren van die activiteiten niet zodanig is dat er blootstellingsniveaus worden bereikt waarbij effecten in dat gebied te verwachten zijn (externe werking). Een uitzondering wordt gemaakt voor de kleine mantelmeeuw van de broedkolonies op Texel die ook foerageert voor de kust van De Koog en waarvoor (in het kader van de voortoets) een effect niet op voorhand kon worden uitgesloten. Deze soort wordt dan ook in dit hoofdstuk betrokken in de effectbeoordeling.

Daarnaast speelt nog de toetsing van de stikstofdepositie aan de betreffende normen. Zie daarvoor hoofdstuk 7.

\subsection{Temporele aanwezigheid}

Een belangrijk deel van de informatie over de ruimtelijke en temporele verspreiding en de gevoeligheid van de Natura 2000-waarden in de Noordzeekustzone die in deze PB wordt gebruikt, is betrokken uit het rapport Natura 2000-doelen in de Noordzeekustzone-Van doelen naar opgaven voor natuurbescherming van Jak et al. (2014a, 2014b). Dit geldt ook voor Tabel 8 waarin een overzicht wordt gegeven van het voorkomen van de natuurdoelen gedurende de maanden van het jaar. Voor de habitattypen zijn de kenmerken jaarrond aanwezig. Voor trekvissen geldt dat deze vrijwel het hele jaar aanwezig kunnen zijn, maar in bepaalde delen van het jaar door trekbewegingen van en naar de zoete wateren talrijker kunnen zijn. De bruinvis is het hele jaar aanwezig en onduidelijk is of er perioden zijn die van speciale betekenis zijn. Aantallen zijn in de Nederlandse kustwateren doorgaans lager in de zomer wanneer als de bruinvis wegtrekt naar voortplantingsgebieden. De twee zeehondensoorten zijn het hele jaar aanwezig in het water om te foerageren en maken het hele jaar door gebruik van platen om op te rusten. Platen worden ook opgezocht voor reproductie en verharing. Voor de grijze zeehond speelt zich dat af in de winter resp. voorjaar; voor de gewone zeehond in zomer resp. nazomer.

Het broedseizoen van de drie soorten broedvogels loopt ongeveer van april tot juli (Tabel 8). De niet-broedvogels zijn in deze periode juist afwezig of in relatief lage aantallen aanwezig, tenzij vanuit broedgebieden gefoerageerd wordt in de Noordzeekustzone (zoals aalscholver en kluut). De 
overige niet-broedvogels zijn soorten die wintergast of doortrekker zijn en gebruiken de Noordzeekustzone vooral als slaapplaats, hoogwatervluchtplaats en/of foerageergebied.

De installatieactiviteiten voor de Slow Mill-pilotinstallatie zijn in de periode maart tot en met juli en de ontmanteling in de maand april (Tabel 2). Dit is relatief gezien een gunstige periode om verstoring van niet-broedvogels te beperken ( $T a b e / 8)$. De maand maart is wat minder gunstig en daarom zou de start van de installatieperiode beter een maand kunnen worden opgeschoven naar april. Een uitloop van de installatieperiode naar augustus is niet ongunstig.

Tabel 8 Overzicht van het temporele voorkomen van de Natura 2000-waarden in de Noordzeekustzone op basis van geraadpleegde literatuur (Doelendocumenten; SOVON, 2007; de Jong et al., 2010). Lichtgrijs = aanwezig; Donkerder grijs = >25\% t.o.v. maximum; Donkergrijs $=>50 \%$ t.o.v. maximum; Zwart = maand waarin maximum aantal aanwezig is

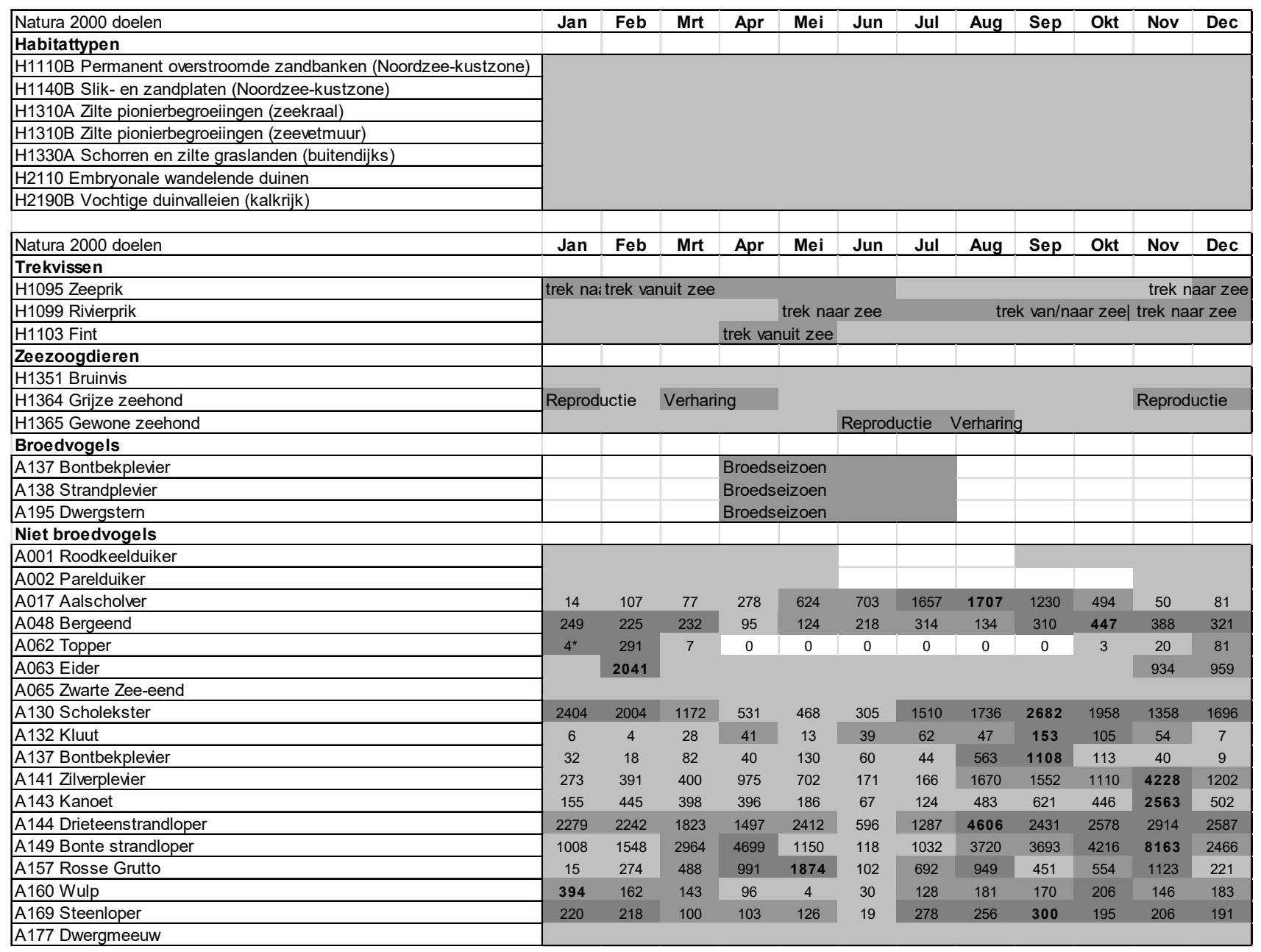

Jak et al. (2014b) hebben de samenhang tussen de afzonderlijke Natura 2000-waarden, kernopgaven en doelen met een sense of urgency geschetst in een tabel die gebruikt wordt bij deze PB (Tabel 9). In die tabel is een koppeling van de Natura 2000-soorten en de habitattypen waarin zij voorkomen, aangebracht. 
Tabel 9 Samenhang tussen habitattypen, soorten, functie van de gebieden en periodes van voorkomen van de soorten. $F=$ foerageergebied, $b=$ bodemdier, $p=$ plankton, $t=$ tweekleppige, $v=v i s, R=$ rustgebied, $B=$ broedgebied, $V=$ voortplantingsgebied, $D=$ doortrek/leefgebied. De doelen waarvoor een sense of urgency geldt, zijn onderstreept, bij de cursief weergegeven doelen betreft het een opgave m.b.t. watercondities, voor de overige geldt een opgave m.b.t. beheer. In blauw is de belangrijkste samenhang tussen de verschillende doelen weergegeven. Voor de gewone zeehond geldt dat $H 1140 B$ voor voortplanting van belang is in de zomer (juni-juli), voor de grijze zeehond in de winter (november-januari). Voor de bontbekplevier is $\mathrm{H} 2110$ als broedgebied van belang in de periode april-juli.

\begin{tabular}{|c|c|c|c|c|c|c|c|c|}
\hline Habitattype & Kernopgave & \multirow{5}{*}{\begin{tabular}{|l} 
Soort \\
Eider \\
Topper \\
Zwarte zee-eend \\
Roodkeelduiker \\
\end{tabular}} & \multicolumn{5}{|c|}{ Functie } & \multirow{2}{*}{\begin{tabular}{|l} 
Periode \\
jaarrond
\end{tabular}} \\
\hline \multirow{14}{*}{$\begin{array}{c}\frac{\text { H1110B }}{\text { Permanent }} \\
\frac{\text { overstroomde }}{\text { zandbanken }}\end{array}$} & \multirow{4}{*}{$\begin{array}{l}1.01 \text { Overstroomde } \\
\text { zandbanken }\end{array}$} & & $F$ & $t$ & $\mathrm{R}$ & & & \\
\hline & & & $F$ & $\mathrm{t}$ & $\mathrm{R}$ & & & winter \\
\hline & & & $F$ & $\mathrm{t}$ & $\mathrm{R}$ & & & winter \\
\hline & & & $F$ & v & $\mathrm{R}$ & & & winter \\
\hline & & Aalscholver & $\mathrm{F}$ & v & & & & jaarrond \\
\hline & & Dwergmeeuw & $\mathrm{F}$ & v & $\mathrm{R}$ & & & doortrek \\
\hline & & Dwergstern & $\mathrm{F}$ & v & & & & zomer \\
\hline & & Parelduiker & $\mathrm{F}$ & $\mathrm{v}$ & $\mathrm{R}$ & & & winter \\
\hline & & Fint & $\mathrm{F}$ & $v / p$ & & & D & jaarrond \\
\hline & & Rivierprik & $F$ & $\mathrm{v}$ & & & $\mathrm{D}$ & jaarrond \\
\hline & & Zeeprik & $\mathrm{F}$ & $\mathrm{v}$ & & & $\mathrm{D}$ & jaarrond \\
\hline & & Bruinvis & $\mathrm{F}$ & v & & & & jaarrond \\
\hline & 1.02 Zeezoogdieren & Gewone zeehond & $\mathrm{F}$ & v & & & & jaarrond \\
\hline & & Griize zeehond & $\mathrm{F}$ & $\mathrm{v}$ & & & & jaarrond \\
\hline \multirow{14}{*}{$\begin{array}{c}\text { H1140B } \\
\text { Slik- en zandplaten }\end{array}$} & & Steenloper & $F$ & $\mathrm{~b}$ & & & & winter \\
\hline & & Bergeend & $F$ & $b$ & $\mathrm{R}$ & & & jaarrond \\
\hline & & Bontbekplevier & $\mathrm{F}$ & $b$ & & & & jaarrond \\
\hline & & Drieteenstrandloper & $\mathrm{F}$ & b & & & & winter \\
\hline & & Strandplevier & $F$ & $b$ & & & & zomer \\
\hline & & Aalscholver & & & $\mathrm{R}$ & & & jaarrond \\
\hline & \multirow{8}{*}{$\begin{array}{c}1.11 \text { Rust en } \\
\text { foerageergebieden }\end{array}$} & Steenloper & & & $\mathrm{R}$ & & & winter \\
\hline & & Rosse grutto & & & $\mathrm{R}$ & & & winter \\
\hline & & Bonte strandloper & & & $\mathrm{R}$ & & & winter \\
\hline & & Kanoet & & & $\mathrm{R}$ & & & winter \\
\hline & & Scholekster & & & $\mathrm{R}$ & & & jaarrond \\
\hline & & Eider & & & $\mathrm{R}$ & & & jaarrond \\
\hline & & Gewone zeehond & & & $\mathrm{R}$ & V & & jaarrond \\
\hline & & Griize zeehond & & & $\mathrm{R}$ & $\mathrm{V}$ & & jaarrond \\
\hline \multirow{14}{*}{$\begin{array}{c}\text { H1310A\&B; H1330A } \\
\text { Zilte pionierbegroeiingen; } \\
\text { Schorren en zilte } \\
\text { graslanden }\end{array}$} & & Bergeend $^{*}$ & & & $\mathrm{R}$ & & & jaarrond \\
\hline & & Steenloper & & & $\mathrm{R}$ & & & winter \\
\hline & & Bonte strandloper & & & $\mathrm{R}$ & & & winter \\
\hline & & Drieteenstrandloper & & & $\mathrm{R}$ & & & winter \\
\hline & & Rosse grutto & & & $\mathrm{R}$ & & & winter \\
\hline & & Strandplevier & & & $\mathrm{R}$ & B & & zomer \\
\hline & & Wulp & & & $\mathrm{R}$ & & & jaarrond \\
\hline & & Zilverplevier & & & $\mathrm{R}$ & & & winter \\
\hline & & Aalscholver & & & $\mathrm{R}$ & & & jaarrond \\
\hline & & Dwergstern & & & $\mathrm{R}$ & B & & zomer \\
\hline & & Gewone zeehond & & & $\mathrm{R}$ & & & jaarrond \\
\hline & \multirow{6}{*}{$\begin{array}{c}1.13 \text { Voortplantings } \\
\text { habitat }\end{array}$} & Grijze zeehond & & & $\mathrm{R}$ & & & jaarrond \\
\hline & & Bontbekplevier & & & $\mathrm{R}$ & B & & jaarrond \\
\hline & & Kluut ${ }^{*}$ & & & $\mathrm{R}$ & & & jaarrond \\
\hline$\underline{\mathrm{H} 2110}$ & & Bontbekplevier & & & & $B$ & & zomer \\
\hline Embryonale wandelende & & Strandplevier** & & & & B & & zomer \\
\hline duinen & & Dwergstern & & & & $\mathrm{B}$ & & zomer \\
\hline $\begin{array}{c}\overline{\mathrm{H} 2190} \\
\begin{array}{c}\text { Vochtige duinvalleien, } \\
\text { kalkrijk }\end{array} \\
\end{array}$ & & & & & & & & \\
\hline
\end{tabular}

* Bergeend en kluut Typische soorten van H1330A; ** strandplevier Typische soort van $\mathrm{H} 2110$; *** Met bodems van verschillende ouderdom en meer natuurlijke opbouw van vispopulaties. 


\subsection{Ruimtelijke aanwezigheid}

De ruimtelijke verspreiding van habitattypen, habitatsoorten en vogelsoorten in het studiegebied is al beschreven in paragraaf 4.1.2, gebaseerd op de beschrijvingen en verspreidingskaarten in Jak et al. (2014b), het beheerplan voor de Noordzeekustzone (Ministerie van Infrastructuur en Milieu, 2016a) en dat van Texel (Rijksdienst voor Ondernemend Nederland, 2016), waarin meer detailinformatie is te vinden.

De verspreiding en dichtheid van een aantal soorten vogels en zeezoogdieren en schelpdieren in de kustzone wordt regelmatig gemonitord in opdracht van de Nederlandse overheid. Wij hebben daarom gericht gezocht naar recentere informatie over monitoringsgegevens voor de ruimtelijke verspreiding van een aantal relevante soorten in en rond het studiegebied.

Aarts et al. (2018) en Brasseur et al. (2019) vonden dat zeehonden vaak voor de kust van Texel komen. Dat zal betekenen dat ze ook gebruik maken van het onderhavige studiegebied.

De dichtheden van bruinvissen worden gemonitord (o.a. Geelhoed et al., 2020), maar niet zo fijnschalig dat daar gedetailleerde informatie over de bruinvis in het studiegebied uit kan worden gehaald. Maar we kunnen er wel vanuit gaan dat de bruinvis er wel kan voorkomen. Dit wordt bevestigd door waarnemingen van zeetrektellers (www.trektellen. $\mathrm{nl}$ ).

Het voorkomen van de talrijkste soorten zeevogels en de bruinvis wordt op het Nederlands Continentaal Plat (NCP) gemonitord en is door Fijn et al. (2019) gerapporteerd voor de periode augustus 2018 tot juni 2019. Daartoe behoren de voor de Noordzeekustzone relevante soorten roodkeelduiker, aalscholver, zwarte zee-eend, dwergmeeuw, bruinvis, grijze zeehond en gewone zeehond.

De zwarte zee-eend is vaker geteld in de kustzone, o.a. door Leopold et al. (2013) en veel verspreidingskaarten zijn te vinden in Kleijberg et al. (2019). De zwarte zee-eend komt niet zo vaak voor de kust van Texel. In enkele jaren is de zwarte zee-eend toch wel in het gebied waargenomen en dan soms in grote aantallen (tienduizenden), zoals gerapporteerd door Leopold et al. (2015) en Fijn et al. (2017). De winterverspreiding van Zwarte Zee-eenden in Nederland concentreerde zich in de afgelopen jaren ten noorden van de oostelijke Waddeneilanden en in mindere mate in de Voordelta. In sommige jaren verblijven echter grote groepen op andere plaatsen. In het voorjaar van 2013 en 2014 doken ineens grote aantallen Zwarte Zee-eenden op voor de kust van Texel (Fijn et al., 2017). Dit heeft waarschijnlijk te maken met de grote dichtheid aanwezige voedsel in de zeebodem aldaar.

\subsection{Habitattypen}

\subsubsection{Globale beoordeling}

In deze paragraaf volgt een beschrijving van de (mogelijke) effecten op habitattypen. Van de zeven habitattypen van de Noordzeekustzone komen er vijf (H1310A, H1310B, H1330A, H2110, H2190B) niet voor in het studiegebied. Significante gevolgen voor de instandhoudingsdoelstellingen van deze habitattypen kunnen daarom worden uitgesloten.

Habitattype slik- en zandplaten (H1140B) komt wel voor in het studiegebied, namelijk op het strand bij paal19/20, waar het waarschijnlijk gaat om een strook van enkele tientallen meters breed. Er zijn niet veel organismen in de bodem te vinden, behalve aanspoelsels en wat strandvlooien en (gemshoorn)wormen die als voedsel voor steltlopers kunnen dienen. Er valt een tijdelijk negatief effect te verwachten op de kwaliteit van het habitattype door het ingraven van de kabel. Door de grote dynamiek van het systeem zal naar verwachting een spoedig herstel optreden nadat de kabel is ingegraven. Effecten kunnen niet op voorhand worden uitgesloten, maar zullen waarschijnlijk klein en tijdelijk van aard zijn. Significante gevolgen voor de instandhoudingsdoelstellingen van $\mathrm{H} 1140 \mathrm{~B}$ worden uitgesloten. 
Permanent overstroomde zandbanken (H1110B) komen voor in een groot deel van het studiegebied. $\mathrm{Er}$ is een potentieel negatief effect van de voorgenomen activiteit op dit habitattype door verandering golfslag, verandering dynamiek substraat, vertroebeling, verontreiniging en introductie hard substraat (positief). Een potentieel significant gevolg van deze verstoringsfactoren voor de instandhoudingsdoelstelling van $\mathrm{H} 1110 \mathrm{~B}$ is uit te sluiten omdat het veranderde oppervlak van $\mathrm{H} 1110 \mathrm{~B}$ naar verwachting minder dan 10 ha is. $\mathrm{Er}$ is een potentieel positief effect op de biodiversiteit te verwachten waar zich het Slow Mill-anker bevindt.

Het resultaat van deze globale beoordeling, zoals die ook al in de voortoets is gemaakt, biedt voldoende inzicht en dat betekent dat een gedetailleerde beoordeling van de effecten op deze habitattypen niet nodig is.

\subsection{Trekvissen}

\subsubsection{Globale beoordeling}

De drie trekvissoorten zeeprik, rivierprik en fint komen waarschijnlijk voor in het studiegebied omdat de hele Noordzeekustzone behoort tot hun leefgebied. In de globale beoordeling die is uitgevoerd in de Voortoets werd geconstateerd dat er een potentieel negatief effect van de_Slow Mill-pilotinstallatie op deze soorten is door verwonding en of dood door botsing of verstrikking en verstoring door geluid onder water. Elektromagnetische straling kan effect hebben op zeeprik en rivierprik omdat kraakbeenvissen gevoeliger zijn dan beenvissen, zoals fint. Het is onbekend of deze drie trekvissoorten enig (positief of negatief) effect ondervinden van de introductie van hard substraat. Waarschijnlijk geen, omdat deze soorten alleen trekken in het studiegebied, en zeeprik en rivierprik bovendien parasiteren. Een potentieel gevolg voor de instandhoudingsdoelstellingen van de drie soorten trekvissen hoeft niet per se op te treden, maar kon met de informatie die was verzameld in de voortoets niet op voorhand worden uitgesloten. De verbeterdoelstelling ligt op het verbeteren van de zout-zoet-barrière. De Slow Mill-activiteiten brengen deze verbetering niet in gevaar. Het zou echter wel kunnen dat er voor deze vissen een barrière ontstaat door de elektromagnetische straling uitgaande van de kabel, wat gevolgen voor de populatieontwikkeling kan hebben. Potentieel negatieve effecten op de drie vissoorten en hun instandhoudingsdoelstelling kunnen niet op voorhand worden uitgesloten. Dat is dan ook de reden dat in deze PB een meer gedetailleerde beoordeling van deze verstoringsfactor wordt uitgevoerd (paragraaf 6.4.2).

De overige aandachtsoorten onder de vissen zijn elft, houting, steur en zalm (paragraaf 4.3 en bijlage 5). Over de verspreiding en de bijbehorende aantallen van deze soorten in het studiegebied is zeer weinig bekend. We nemen aan dat ze wel in het studiegebied voorkomen. Elft, houting en zalm zijn wat gevoeligheid voor een Slow Mill-pilotinstallatie betreft waarschijnlijk redelijk vergelijkbaar met de fint. De steur is een kraakbeenvis en daarom relatief gevoelig voor elektromagnetische straling van elektriciteitskabels en bovendien foerageert de steur op benthos en daardoor dichtbij de zeebodem. In de voortoets konden daarom potentieel negatieve effecten van de Slow Mill-pilotinstallaties op de elft, houting, steur en zalm en hun populaties niet op voorhand worden uitgesloten. Een meer gedetailleerde beoordeling van deze vier soorten ten behoeve van deze PB is te vinden in paragraaf 6.4.2.

\subsubsection{Gedetailleerde beoordeling}

De gedetailleerde effectbeoordeling richt zich op de trekvissen met een instandhoudingsdoelstelling in de Noordzeekustzone (zeeprik, rivierprik en fint) en de hiervoor geïnventariseerde relevante trekvissoorten zonder instandhoudingsdoelstelling in de Noordzeekustzone (elft, houting, steur en zalm). Daarbij zijn de volgende drukfactoren van belang:

- Verwonding en of dood door botsing of verstrikking

- Verstoring door geluid onder water

- Elektromagnetische straling / barrièrewerking door de kabel 
Deze beoordeling is opgezet in de volgorde:

- Gevoeligheid voor drukfactoren

- Verspreiding, dichtheid en trend

- Gevolgen voor de instandhoudingsdoelstelling(en)

\subsubsection{Gevoeligheid voor drukfactoren}

\section{Verwonding en of dood door botsing of verstrikking}

Botsingen en/of verstrikkingen van vissen met de Slow Mill-installatie of bekabeling kunnen verwondingen of, in het ergste geval, dood tot gevolg hebben. Dit is echter niet onderzocht voor de Slow Mill, omdat die er nog niet is, maar ook niet voor WECs in zijn algemeenheid, want het kan moeilijk worden onderzocht, zoals gemeld door Copping (2020). Op basis van de best beschikbare kennis concluderen wij dat incidenten niet kunnen worden uitgesloten maar er geen significant effect van deze verstoringsfactor van de Slow Mill-installatie op vissen te verwachten is. Hun habitat is immers vol van (natuurlijke en onnatuurlijke) objecten, waarmee zij moeten omgaan. Bekend is dat vissen aarzel- of ontwijkingsgedrag laten zien in voor hen ongewone situaties. Aanwijzingen dat vissen in staat zijn hun omgeving als veilig of onveilig te ervaren en daarop te reageren, zijn te vinden in tal van onderzoeken naar de vangbaarheid van vissen.

\section{Verstoring door geluid onder water}

Bij het plaatsen van de verankering, de elektriciteitskabel en het plaatsen en onderhouden van de Slow Mill vindt verstoring door geluid onder water plaats. Vissen zijn gevoelig voor verstoring door onderwatergeluid en kunnen hiervan opschrikken en het gebied mijden. De verstoring door de bovengenoemde werkzaamheden is echter van korte duur, en de vissen kunnen na deze tijdelijke verstoring terug keren in het gebied. Echter, het geluid dat de WECs zelf produceren wanneer zij in bedrijf zijn, kan in potentie wel voor langdurige verstoring zorgen. Copping (2020) constateerde in een overzichtsstudie naar de mogelijke effecten van WECs, dat de effecten van de onderwatergeluidproductie van de huidige kleinere MREs nog onvoldoende onderzocht en begrepen zijn. Het lijkt echter onwaarschijnlijk dat dit continugeluid significante invloed heeft op het gedrag van vissen, of fysiek letsel oplevert.

Het risico op het optreden van effecten van onderwatergeluid op het verspreidingspatroon van vissen in het gebied rond een WEC hangt sterk samen met het patroon van de sterkte en de frequentie van het geluid. Dit kan voor de Slow Mill niet worden gekwantificeerd wegens het gebrek aan informatie over de onderwatergeluidsproductie van de Slow Mill.

Vanwege het ontbreken van informatie over effecten van WECs via onderwatergeluid (en elektromagnetische straling, behandeld in de volgende paragraaf), hebben wij gezocht naar bruikbare informatie over effecten van onderwatergeluid dat wordt veroorzaakt door andere statische structuren op zee. Daarbij kwamen wij uit bij windturbines op zee. Wat we van de verspreiding van vissen in de buurt van windturbines op zee weten, is dat er trade-offs kunnen spelen. Ondanks potentiële negatieve effecten van onderwatergeluid en elektromagnetische velden (in het Engels electromagnetic field: EMF) zijn in windparken hogere dichtheden van vissen in de buurt van de windturbines waargenomen (Van Hal et al., 2012; Bergström et al., 2013). Een telemetrie-experiment met kabeljauw toonde geen voorkeur van kabeljauw voor turbines die buiten werking waren, boven turbines die wel in werking waren (Winter et al., 2010). Hieruit kan afgeleid worden dat de eventueel optredende negatieve effecten van onderwatergeluid en elektromagnetische straling, de positieve werking van geïntroduceerde harde structuren zoals turbinefundaties, waar vissen voedsel en beschutting kunnen vinden, niet overstijgen. Hierbij moet wel worden opgemerkt dat de in die studies waargenomen vissoorten niet behoren tot de groep van trekvissoorten. Gezien het verschil in omvang tussen een windturbine en een kleine WEC als de Slow Mill concluderen wij op basis van deze kennis dat er geen significante effecten door onderwatergeluid van de Slow Mill-installatie op (trek)vissen te verwachten zijn.

\section{Elektromagnetische straling / barrièrewerking door de kabel}

In de voortoets werden slechts enkele publicaties over de EMFs van WECs gevonden (namelijk Witt et al., 2012; Haikonen et al., 2013; Copping, 2020) en deze wezen erop dat nog weinig bekend is en 
daaruit kunnen geen harde conclusies kunnen worden getrokken. Vanwege deze kennislacunes voor WECs, is voor deze PB gezocht naar publicaties met informatie over de potentiële effecten van stroomkabels van windparken op zee op vissen en zeezoogdieren, teneinde die informatie aan te kunnen wenden voor de inschatting van potentiële effecten van de stroomkabel van WECs en meer specifiek van de Slow Mill. Daarbij moet wel worden bedacht dat die informatie dan worst case is wanneer deze wordt geëxtrapoleerd van windparken naar een kleinschalige WEC zoals de Slow Mill. Het is namelijk wel duidelijk dat het EMF rond een kabel afhankelijk is van de eigenschappen van de kabel en de hoeveelheid getransporteerde stroom die in geval van windturbines afhankelijk is van de weersomstandigheden (windsnelheid) waaronder energie wordt gewonnen. Voor de Slow Mill zal iets vergelijkbaars gelden. Hoewel het EMF van de transportkabel van de Slow Mill in werking niet bekend is. moet worden aangenomen dat de stoomsterkte in de kabel en daarom ook het EMF rond de kabel van de Slow Mill aanzienlijk kleiner is dan die in de exportkabels van offshore-windparken. De diepte onder het zeebodemoppervlak van de kabels van de windparken OWE, PAWP en Luchterduinen varieert tussen de 1,5 en 1,9 m. De transportkabel van de Slow Mill wordt op een diepte van minimaal $2 \mathrm{~m}$ ingegraven.

Hieronder wordt ingegaan op de bevindingen van acht publicaties die de potentiele effecten van EMF op vissen hebben onderzocht (Gill et al., 2012; Woodruff et al., 2013; Love et al., 2017a, 2017b; Hutchison et al. 2018; Wyman et al., 2018, Snoek et al., 2020) of gereviewd (Snoek et al., 2016, 2020).

In een literatuurstudie van Snoek et al. (2016) naar de potentiële effecten van EMFs in de Nederlandse Noordzee wordt geconcludeerd dat de vier belangrijkste effecten zijn: de verstoring van1) gedragsrespons en beweging (aantrekking, ontwijking); 2) navigatie- en migratiegedrag; 3) predator/prooi-interacties en de verdeling van prooi; 4) fysiologie, embryo- en celontwikkeling. Er is in het algemeen een gebrek aan effectstudies van EMFs, specifiek op Noordzee soorten. De sterkte van een EMF is afhankelijk van vele factoren, zoals het type kabel (geschikt voor wisselstroom versus gelijkstroom)) en de elektrische stroom rond de kabel. De sterkte van een gegenereerd EMF neemt snel af met de afstand tot de kabel, maar is hoogstwaarschijnlijk in de range die gedetecteerd kan worden door mariene organismen. Hoge EMF-gevoeligheid wordt verondersteld voor elasmobranchen (haaien, roggen), maar ook invertebraten; beenvissen en zeezoogdieren van de Noordzee kunnen potentieel effect ondervinden van EMFs. Soorten die op of bij de bodem leven en dus vaker een kabel tegenkomen dan de andere soorten, worden daarom waarschijnlijk meer beïnvloed.

Gill et al. (2012) suggereerden dat EMFs van kabels op of in de zeebodem invloed kunnen hebben op migrerende trekvissen als hun migratieroute over kabels in ondieper water $(<20 \mathrm{~m})$ gaat. Het effect is een tijdelijke verandering van zwemrichting. Er is enig bewijs dat sommige vissoorten gevoelig zijn voor elektrische of magnetische velden. Dit gaat om de soorten rivierprik, zeeprik, steur, zalm, zeeforel en Europese aal. Voor andere trekvissoorten, inclusief fint, elft en houting, is geen informatie beschikbaar in de wetenschappelijke literatuur.

$\mathrm{Er}$ is een laboratoriumexperiment bekend waarin het gedrag van een vissoort werd onderzocht bij een bekende intensiteit van een EMF. Woodruff et al. (2013) vonden dat de Atlantische heilbot relatief weinig gedragsrespons vertoonde die wees op een expliciete ontwijking of aantrekking bij een EMF van 1,1 mT gelijkstroom.

Metingen in de veldsituatie naar de EMFs van kabels van windparken zijn uitgevoerd door Snoek et al. (2020), simultaan met video-observaties van mobiele megafauna (invertebraten en vissen). Er konden geen duidelijke conclusies worden getrokken uit de resultaten betreffende de effecten op soortgroepen in deze veldstudie. Daarnaast hebben Snoek et al. (2020) een recente update gedaan van de internationale wetenschappelijke literatuur ten opzichte van hun eerdere review (Snoek et al., 2016), namelijk voor de periode 2017-2019, betreffende EMFs en effecten op marien leven in de Noordzee. Zij beschrijven dat ook eerdere veldstudies (Love et al. 2017a, 2017b) een gevarieerd beeld gaven: visgemeenschappen laten geen statistische verschillen zien tussen gebieden met variërende EMFs. De dichtheid aan vissen kan hoger zijn vlakbij kabels, maar dit wordt waarschijnlijk verklaard door verschil in habitatstructuur (toevoeging van hard substraat). EMFs hebben een effect op het gedrag van kleine roggen (Hutchison et al. 2018), maar gemengde en beperkte effecten op smolts (jonge 
zalmen) (Wyman et al. 2018). Op basis van deze studies is er geen bewijs voor een barrière-effect door EMFs van kabels op de beweging van vissen: de EMFs hielden de soorten niet tegen om de kabels te passeren.

Vanwege de afwezigheid van aangetoonde negatieve effecten van elektromagnetische straling van offshore windparken op vissen, en het feit dat de Slow Mill-kabels een veel kleiner spanningsniveau hebben dan die van de kabels in offshore-windparken, kan er worden geconcludeerd dat significant negatieve effecten van de Slow Mill via elektromagnetische straling en barrièrewerking op trekvissen niet te verwachten zijn.

\subsubsection{Verspreiding, dichtheid en trend}

In paragraaf 4.1.2.2 is reeds informatie gegeven over de verspreiding van de zeeprik, rivierprik en de fint. Deze drie soorten trekken vanuit zee de rivieren op om er te paaien. De zeeprik trekt in februarijuni de rivier op, de rivierprik in het najaar, en de fint kort voor de paaiperiode in mei-juni. Het grootste gedeelte van hun leven brengen ze door op zee, waarbij wordt vermoed dat kustwateren van groot belang zijn. Het belang van de Noordzeekustzone voor de trek van deze vissen is waarschijnlijk beperkt, maar de kennis daarover is schaars. De trek tussen zoet en zout water vindt vooral plaats in estuaria zoals het Eems-estuarium en de sluizen van de Afsluitdijk. Trekvissen komen echter ook via de zeegaten de Waddenzee binnen, zoals het Marsdiep ten zuiden van Texel en het Eierlandse gat ten noorden van Texel. Er is in deze PB ten opzichte van deze informatie geen extra of gedetailleerdere informatie te geven over de verspreiding van deze vissoorten. Dat geldt ook met betrekking tot de dichtheid en trend van zeeprik, rivierprik, fint en de overige voor de PB relevante trekvissen in de Noordzeekustzone, en dus ook in het studiegebied. Dit is een kennislacune, maar voor de beoordeling van potentiële effecten van de Slow Mill op deze trekvissen niet bezwaarlijk omdat hierboven al is geconcludeerd dat de gevoeligheid van trekvissen voor de voorgenomen activiteiten waarschijnlijk zeer gering is.

\subsubsection{Gevolgen voor instandhoudingsdoelstellingen}

Voor alle beschermde vissoorten van het Natura 2000-gebied Noordzeekustzone geldt een behoudsdoelstelling ten aanzien van de omvang van het (leef)gebied, een behoudsdoelstelling ten aanzien van de kwaliteit van het (leef)gebied, en een verbeterdoelstelling ten aanzien van de populatie.

De best beschikbare informatie levert geen aanwijzingen dat door kleinschalige WECs als de Slow Mill via botsingen en verstrikking, onderwatergeluid, EMF en/of barrière-werking effecten op populatieniveau van de trekvissen zeeprik, rivierprik, fint, elft, houting, steur en zalm optreden. Op basis daarvan worden negatieve gevolgen van de Slow Mill-installatie en bijbehorende werkzaamheden voor de instandhoudingsdoelstellingen van deze soorten uitgesloten.

\section{5 (Zee)zoogdieren}

\subsubsection{Globale beoordeling}

Gewone zeehonden, grijze zeehonden en bruinvissen maken regelmatig gebruik van het studiegebied. De Slow Mill-pilotinstallatie kan een potentieel negatief effect hebben door de verstoringsfactoren verwonding en/of dood door botsing en verstrikking, verstoring door geluid en elektromagnetische straling. Zeehonden zouden mogelijk wel kunnen profiteren van een hoger voedselaanbod bij de Slow Mill-installatie. Bruinvissen zullen daar waarschijnlijk niet van profiteren omdat ze waarschijnlijk afstand zullen houden tot de Slow Mill-installatie.

Een potentieel negatief effect voor instandhoudingsdoelstellingen van deze drie soorten zoogdieren was in de voortoets niet op voorhand uit te sluiten. Hierbij speelt mee dat er kennislacunes zijn betreffende de gevoeligheid voor botsingen en verstrikkingen met WECs in het algemeen en met de 
Slow Mill-pilotinstallatie in het bijzonder, en de geluidsniveaus die worden geproduceerd door de Slow Mill-pilotinstallatie. Dat is de reden dat in deze PB een meer gedetailleerde beoordeling wordt uitgevoerd in de volgende paragraaf.

De overige aandachtsoorten onder de zoogdieren in het studiegebied zijn laatvlieger, gewone dwergvleermuis, noordse vleermuis, rosse vleermuis, ruige dwergvleermuis, tweekleurige vleermuis. (paragraaf 4.3 en Bijlage 5). Deze soorten verblijven alleen boven zee tijdens de zomer om er te foerageren en tijdens de doortrek. Vleermuizen zullen niet worden aangetrokken tot WECs zoals de Slow Mill-pilotinstallatie omdat deze amper boven het zeeoppervlak uitkomt. Vleermuizen zullen niet op de installaties gaan rusten, en botsingen en andere effecten worden daarom uitgesloten (Sander Lagerveld (WMR), pers. med.).

\subsubsection{Gedetailleerde beoordeling}

In deze paragraaf wordt een nadere en gedetailleerdere effectbeoordeling uitgevoerd, gericht op de potentiële effecten op de bruinvis, grijze zeehond en gewone zeehond van de (activiteiten voor de) Slow Mill door de drukfactoren:

- Verwonding en of dood door botsing of verstrikking

- Verstoring door geluid onder water

De beoordeling is opgezet in de volgorde:

- Gevoeligheid voor drukfactoren van WECs

- Verspreiding, dichtheid en trend

- Gevolgen voor de instandhoudingsdoelstellingen

\subsubsection{Gevoeligheid van zeezoogdieren voor WECs}

Voor de beoordeling van de mogelijke invloed van de Slow Mill-installatie op zeezoogdieren, zijn wij aangewezen op informatie over andere WECs en andere installaties zoals getijdenturbines (o.a. Kastelein \& Jennings, 2019, Copping, 2020). Deze informatie is hier echter maar van beperkte waarde omdat de Slow Mill (afmeting en vorm) en de bewegende delen (afmeting, constructie, bewegingssnelheid) daarvan, en de lokale omstandigheden (voor de kust van Texel) uniek zijn. Toch kan hier zinvol gebruik worden gemaakt van gedragsstudies aan zeezoogdieren om hun reactie op objecten (hier: de Slow Mill) te kunnen inschatten.

Voor de beoordeling van de effecten van de Slow Mill op bruinvissen en zeehonden, dienen de volgende vragen te worden beantwoord:

- Wat is de kans dat bruinvissen en zeehonden met de Slow Mill-bladen botsen, en wat zijn de potentiële effecten van eventuele botsingen op deze dieren?

- Wat is het effect op bruinvissen en zeehonden van de Slow Mill als een potentiële barrière voor verplaatsing in de Noordzeekustzone voor de kust van Texel?

- Wat is het effect van geluid van een in werking zijnde Slow Mill op bruinvissen en zeehonden?

Hieronder wordt eerst ingegaan op de effecten op bruinvissen en daarna op effecten op zeehonden.

\section{Effecten van WECs op bruinvissen}

Bruinvissen gebruiken echolocatie voor hun oriëntatie en om te foerageren ( $A u, 1993)$. De meest gebruikte frequentie van bruinvisecholocatieklikken is ongeveer $125 \mathrm{kHz}$ (Møhl \& Andersen, 1973). Naast de echolocatie voor detectie van objecten (hier: van de bladen) gebruiken bruinvissen zicht. Zij hebben een tapetum lucidum en kunnen daarom zien bij lage lichtintensiteit in diep en troebel water en in de schaduwzone van objecten, ook 's nachts (Kastelein et al., 1990). 
Bruinvissen vermijden het gebruik van doorgangen die zij als nauw ervaren, zelfs in het geval van voldoende ruimte voor de gelijktijdige passage van meerdere exemplaren (Kastelein et al., 1997). Bruinvissen laten echter wel een individuele variatie zien in hun gedrag en reactie ten opzichte van objecten en geluiden (Kastelein et al., 2000, 2001, 2005, 2008, 2018), en dit hangt af van factoren zoals individueel karakter, ervaring, leeftijd en sexe, en de context, zoals de locatie, stroming, waterdiepte, of de bruinvis alleen of in een groep is, weersomstandigheden, seizoen, etc.. Het is dus mogelijk dat enkele bruinvissen de Slow Mill wel zouden gaan benaderen, terwijl andere dat nooit zullen doen.

Mocht een gezonde bruinvis de Slow Mill wel heel dicht naderen dan is het onwaarschijnlijk dat deze zal botsen met de bladen van de Slow Mill. De bladen van de Slow Mill bewegen relatief traag omdat ze meebewegen met de golven. De golfperiode op de Noordzee is variabel maar kan gemiddeld ca. 6 seconden zijn (Groen en Dorrestein, 1976)). Met die bewegingssnelheid van de bladen, is het aannemelijk dat bruinvissen de bladen gemakkelijk kunnen ontwijken.

Een bruinvis die de Slow Mill benadert en wordt blootgesteld aan een toenemend geluidsniveau, kan ervoor kiezen daarvan weg te zwemmen en zodoende de Slow Mill te ontwijken. Er zijn echter geen onderwatergeluidmetingen vlakbij de Slow Mill uitgevoerd. Afhankelijk van het spectrum en bronniveau en de lokale condities, kan het door de Slow Mill geproduceerde geluid wel of geen effect op het gedrag van de bruinvis hebben. In geval het geluid, dat wordt geproduceerd door de bewegende bladen, voor een bruinvis in de nabijheid hoorbaar is, zal dat de bruinvis helpen de Slow Mill te ontwijken en te behoeden voor botsingen. Een barrière-werking van de Slow Mill op de verplaatsingen van bruinvissen wordt niet verwacht door de locatie van de Slow Mill-installatie, de vorm van de installatie en het relatief geringe ruimtebeslag (zie paragraaf 3.2.1 en Figuur 4).

\section{Effecten van WECs op gewone zeehond en grijze zeehond}

Voor gewone zeehonden zijn waarnemingen in gevangenschap en in het wild met betrekking tot hun gedrag ten opzichte van objecten en obstakels bekend, maar dat geldt in veel mindere mate voor grijze zeehonden. Grijze zeehonden zijn qua lichaamsbouw de sterkere soort: lengte max. $3 \mathrm{~m}$ en gewicht max. $280 \mathrm{~kg}$ versus respectievelijk 1,90 m en $120 \mathrm{~kg}$, en zijn ook minder schuw dan gewone zeehonden. Wij nemen aan dat de beide soorten redelijk vergelijkbaar zijn in hun (zwem)gedrag en baseren onze beoordeling hieronder op wat er bekend is over het gedrag van de relatief gezien minder 'robuuste' gewone zeehond.

Gewone zeehonden gebruiken drie waarnemingsmethoden voor foerageren en oriëntatie: zicht, gehoor en tast. Hun onderwaterzicht is beter dan dat van mensen vanwege hun tapetum lucidum (Braekevelt, 1986). Zeehonden kunnen vissen detecteren door te luisteren naar de lage frequentie van het onderwatergeluid dat deze produceren (Kastelein et al., 2009), en met hun snorharen, die waterbewegingen van zwemmende vissen waarnemen (Dehnhardt et al., 2001). Gewone zeehonden zijn dieren die gewend zijn om te leven in kustwateren met branding, stroming, geluid en turbulentie bij relatieve troebelheid, en komen in havens en in offshore-windparken met de daar aanwezige objecten

Uit waarnemingen in gevangenschap is bekend dat zeehonden niet bang zijn om door nauwe ruimten te zwemmen. Telemetriedata en ervaring met zeehonden in gevangenschap laten wel zien dat individuele zeehonden onderling wel heel verschillend kunnen reageren (Kastelein et al., 2006 a,b; 2015; 2017; Leopold \& Scholl, 2018). Het zijn goede zwemmers die snel kunnen bewegen.

Volwassen zeehonden zullen waarschijnlijk niet proberen om tussen de lamellen van de Slow Mill door te zwemmen, omdat daar geen reden voor is. Dat zou anders kunnen zijn voor jonge dieren.

Gegevens uit de beginjaren zeventig/eindjaren tachtig over verdrinking van zeehonden in fuiken lieten zien dat toen overwegend jonge zeehonden het slachtoffer van deze vangsttuigen werden (Reijnders 1985, Dankers \& Zegers 1985). Aangenomen moet worden dat dit te maken heeft met de onervarenheid van jonge dieren maar vooral ook met de geringe lichaamsgrootte. Uit experimenten is bekend dat zeehonden in schietfuiken met een keel van $16 \mathrm{~cm}$ (en uiteraard groter) kunnen geraken 
(Reijnders et al. 2005) en dat dit kan worden voorkomen wanneer er een keerwant wordt aangebracht met een maximale maaswijdte van $10 \times 10 \mathrm{~cm}$ (ofwel $20 \mathrm{~cm}$ gestrekt).

De ruimte tussen de lamellen van de Slow Mill varieert van 21 tot $35 \mathrm{~cm}$, en die tussen de bovenste lamellen en de drijver is ca. $30 \mathrm{~cm}$. Qua afmetingen is het mogelijk dat jonge/kleinere zeehonden erdoorheen proberen te zwemmen, maar analoog aan de bevindingen van Leopold \& Scholl (2018) wordt aangenomen dat dit niet gauw gebeurt. Anders dan bij een fuik, is bij de lamellen geen prooi te halen (tenzij er net een school vissen zwemt). Zeehonden kunnen de Slow Mill zien en zijn fysiek in staat deze te ontwijken. Als zij per ongeluk, of toch op jacht naar een vis, tussen twee lamellen zijn geraakt, zullen zij proberen zich eruit te bevrijden en daar mogelijk ook in slagen. Dat laatste geldt dan voor de kleinere exemplaren omdat zij klein zijn (vergelijk met de fuik) en voor de grotere op grond van hun fysieke kracht. Dodelijke incidenten zijn echter niet geheel uit te sluiten. Wanneer zeehonden alleen kortstondig in aanraking komen met de Slow Mill, die door verankering op een punt een zwaaiende beweging maakt, zullen zij gezien hun sterke lichaamsbouw niet snel een trauma oplopen. Aangenomen moet worden dat botsingen en het vast komen te zitten van zeehonden tussen lamellen niet uit te sluiten zijn, maar beperkt zullen blijven tot incidenten, die ook opgemerkt zullen worden wanneer niet de betrokken zeehond maar de lamellen beschadigd worden.

Men moet wel voorzichtig zijn met het extrapoleren van waarnemingen van gedrag van zeehonden ten opzichte van bepaalde turbines of WECs op bepaalde locaties naar andere objecten en locaties. Er is namelijk ook een studie beschikbaar waarin werd gevonden dat gewone zeehonden niet nabij een getijdenturbine kwamen. Joy et al. (2018) vonden dat de meeste gewone zeehonden een SeaGenturbine in Noord-Ierland niet benaderden tot minder dan $200 \mathrm{~m}$. Als dat bij de Slow Mill het geval is, zou dat een zeer gering habitatverlies betekenen, maar ook dat de kans op botsingen dan nihil is.

Wij kunnen hieruit concluderen dat mitigerende maatregelen voor de Slow Mill met betrekking tot zeehonden niet nodig zijn omdat WECs waarschijnlijk geen of hooguit minimale effecten op zeehonden hebben.

\subsubsection{Verspreiding, dichtheid en trend}

Ruimtelijke verspreiding en dichtheid

Het is van belang zicht te krijgen op de dichtheden van de bruinvis en de beide zeehondensoorten in het studiegebied van de Slow Mill en daarmee het belang van het studiegebied voor deze soorten. Hiervoor is informatie verzameld die wordt beschreven voor achtereenvolgens bruinvis en de zeehonden.

\section{Bruinvis}

$\mathrm{Er}$ is voor deze PB gezocht naar informatie over de aantallen en dichtheden van bruinvissen in het gebied rondom de beoogde locatie voor de Slow Mill-installatie, alsmede in een veel groter gebied, namelijk de Nederlandse Noordzee. Op de website van www.trektellen.nl zijn telgegevens van bruinvissen te vinden die zijn gedaan vanaf paal 15 op Texel en betrekking hebben op de kustnabije wateren die relevant zijn voor de beoogde Slow Mill locatie. Telwaarnemingen van bruinvissen in de periode 1972-2021 geven echter mogelijk geen goed beeld van de gemiddelde dichtheid aan bruinvissen. Er is namelijk een zeer grote variatie tussen de jaren in de telinspanningen. In de 49jarige periode is het gemiddelde aantal bruinvissen per teluur per jaar 1,77 . De mediane waarde is 0,00 en de maximale waarde is 51,48 .

De huidige informatie over de verspreiding van bruinvis in de Nederlandse Noordzee is gebaseerd op de volgende gegevens, inclusief de beperkingen daarvan:

- Design-based aantallen en verspreiding a.d.h.v. gestandaardiseerde vliegtuigtellingen in de Nederlandse Noordzee (Geelhoed et al., 2013; Geelhoed \& Scheidat, 2018)

De beperkingen daarvan zijn met name temporeel omdat er niet gedurende het hele jaar is gemonitord. 
- Habitat-model based aantallen en verspreiding a.d.h.v. internationale data verzameld tijdens gestandaardiseerde vliegtuigtellingen in de Noordzee (Gilles et al., 2016), zie Figuur 17. Naast de boven genoemde vliegtuigtellingen op het NCP hebben Gilles et al. (2016) ook gebruik gemaakt van andere vliegtuigtellingen in de Noordzee, waaronder de grensoverschrijdende SCANS-tellingen (Hammond et al., 2013).

De seizoenkaarten met de dichtheid van de bruinvis op het NCP zijn te zien in Bijlage 7. Voor de kust van Texel is het aantal exemplaren per $\mathrm{km}^{2}$ tussen 0.0 en 0.8 in de zomer en de herfst, en tussen 0.0 en 1.2 in het voorjaar. Dit is ongeveer gemiddeld voor de hele Noordzeekustzone. Verder offshore op het NCP is de dichtheid van bruinvissen vaak groter.

\section{Zeehonden}

Er zijn publicaties beschikbaar met zenderdata van zeehonden in de Nederlandse wateren, die zijn verzameld in het kader van diverse onderzoeken (o.a. Aarts et al. 2016). Ten bate van detailonderzoek op specifieke locaties zijn veel grijze en gewone zeehonden gezenderd met gedetailleerde GPS-zenders vanuit verschillende locaties en verschillende seizoenen. Ondanks deze hoge aantallen, zijn er zowel ruimtelijk als temporeel beperkingen van deze gegevens. Uit deze zenderdata blijkt dat de gehele Nederlandse kustzone, inclusief de kustzone voor Texel, intensief wordt gebruikt door beide zeehondensoorten.

Zenderdata en populatietellingen op land vormen de basis voor verspreidingsmodellen van zeehonden op zee (o.a. Aarts et al. 2016). Hiermee wordt een voorspelling gemaakt van de dichtheden van de gewone en grijze zeehonden op zee. De twee soorten vertonen sterke verschillen, die te maken hebben met de historie (grijze zeehonden hebben pas rond 1985 Nederland gekoloniseerd), grootte en seizoenspatroon (grijze zeehonden planten zich voort in de winter, gewone zeehonden in de zomer).

Voor de gewone zeehonden is er een verspreidingsmodel gemaakt voor de verschillende maanden van het jaar. Sturende factoren in de modellen zijn daarnaast de verspreiding op land, de bathymetrie en bodemsoort (Aarts et al. 2016). Een kaart met de dichtheid van de gewone zeehond op het NCP in de maand september is te zien in Bijlage 7. Voor de kust van Texel is de dichtheid $>0.1$ en $\leq 0.5$ exemplaren per $\mathrm{km}^{2}$. Dit is ongeveer gemiddeld in de Noordzeekustzone, waarin de dichtheid hoger is bij de Razende Bol en in de zeegaten tussen de eilanden, maar hoger dan voor de vastelandskust van Noord-Holland. Verder offshore op het NCP is de dichtheid vaak kleiner.

In deze modellen is nog geen rekening gehouden met de invloed van menselijke activiteit. Men dient zich te realiseren dat de bewegingen die zijn gemeten aan individuele dieren alleen, niet representatief zijn voor de soort. De registraties van bewegingen van zeehonden geven echter aan dat er dieren in het gebied waar de Slow Mill is gepland, kunnen voorkomen. Er is geen vergelijkbaar verspreidingsmodel opgesteld voor de grijze zeehonden.

\section{Trend aantallen zeezoogdieren}

Het is van belang te weten hoe de aantallen zeezoogdieren in het Natura 2000-gebied zich in de laatste jaren hebben ontwikkeld. Met die informatie is mogelijk in te schatten of de instandhoudingsdoelstellingen van de zeezoogdiersoorten wel of niet zullen worden gehaald en de gevoeligheid daarvan voor de invloed van mogelijk negatieve effecten van nieuwe projecten en plannen in het gebied, zoals de installatie en operationele fase van de Slow Mill.

\section{Bruinvis}

Op de site van www.trektellen.nl staan telwaarnemingen van bruinvissen gedaan bij paal 15 op Texel met zicht op de beoogde locatie voor de Slow Mill. Er zijn gegevens over een lange periode, maar er is geen significante trend, mede door de enorme variatie in de aantallen bruinvissen per teluur per jaar, terwijl in de meeste jaren dat aantal getelde bruinvissen per uur 0 is. Er is ook gekeken naar gegevens voor de dichtheid van bruinvissen in vier grote gebieden (Dogger Bank, Offshore, Friese Front en Delta) op het NCP op basis van monitoring met vliegtuigtellingen, zoals die worden gegeven 
door Geelhoed et al. (2020). Deze bruinvis dichtheid data zijn beschikbaar voor de jaren 2010, 2014, 2015, 2017, 2018 en 2019 en duiden niet op een statistisch significant verschil tussen de jaren. De auteurs merken wel op dat de tijdserie relatief kort is om een trend te kunnen meten. Wij kunnen concluderen dat een trend voor de bruinvis is de Noordzeekustzone niet kan worden bepaald omdat dat gebied slechts een klein deel uitmaakt van het verspreidingsgebed van de bruinvis. De Noordzeepopulatie van de bruinvis wordt geschat op 345.000-361.000 individuen, waarvan er een vijfde deel aanwezig is op het NCP in de zomer-surveys in de periode 2010-2019 (Geelhoed et al., 2020).

\section{Grijze zeehond en gewone zeehond}

\section{Gewone zeehond}

Voor inzicht in de omvang en trend ven de populaties van beide zeehondensoorten kan gebruik worden gemaakt van de jaarlijkse tellingen in de Waddenzee die internationaal tussen Nederland, Duitsland en Denemarken worden gecoördineerd en gerapporteerd. In 2020 kwam de totaaltelling van de gewone zeehond in de hele Waddenzee op 28.352 dieren ( $2 \%$ meer dan in 2019) en is de schatting voor de totale populatie 41.700 dieren (Galatius et al. 2020). Omgerekend is de schatting voor het aantal gewone zeehonden in het Nederlandse deel ongeveer 10.100 dieren. De populatiegrootte van gewone zeehonden in Nederland, maar ook in de internationale Waddenzee, blijkt sinds 2012 ongeveer gelijk te blijven. Deze informatie is afkomstig van:

https://www.wur.nl/nl/show/Populatie-Gewone-Zeehonden-in-de-Nederlandse-Waddenzee.htm. Het studiegebied van de Slow Mill-activiteiten buiten de Waddenzee en dus ook buiten de hierboven behandelde telgebieden (Figuur 12) ligt wel dichtbij de telgebieden 1 en 2 . De telgebieden zijn belangrijk voor de gewone zeehonden, wanneer wordt afgegaan op de aantallen (Figuur 13 en Bijlage 8). Het is aannemelijk dat veel van de gewone zeehonden in de telgebieden 1 en 2 ook gebruik zullen maken van het studiegebied.

\section{Grijze zeehond}

In de afgelopen vijf jaar zijn de getelde aantallen grijze zeehonden in de internationale Waddenzee gemiddeld jaarlijks met ongeveer $9 \%$ gestegen tijdens de verharingsperiode en dat is vooral toe te schrijven aan de groei in Nederland. In de hele Waddenzee werden in 20206538 grijze zeehonden geteld, waarvan 5687 in Nederland. Het aantal grijze zeehonden voor de Nederlandse Waddenzee wordt geregistreerd voor 12 deelgebieden (wantijgebieden) afzonderlijk (Figuur 12, Figuur 14). De meeste grijze zeehonden worden al jaren gezien in gebied 3 tussen Vlieland en Terschelling, gevolgd door gebied 1 tussen Den Helder en Texel (gebied 1) en gebied 2 tussen Texel en Vlieland (zie Figuur 14 en Bijlage 8).

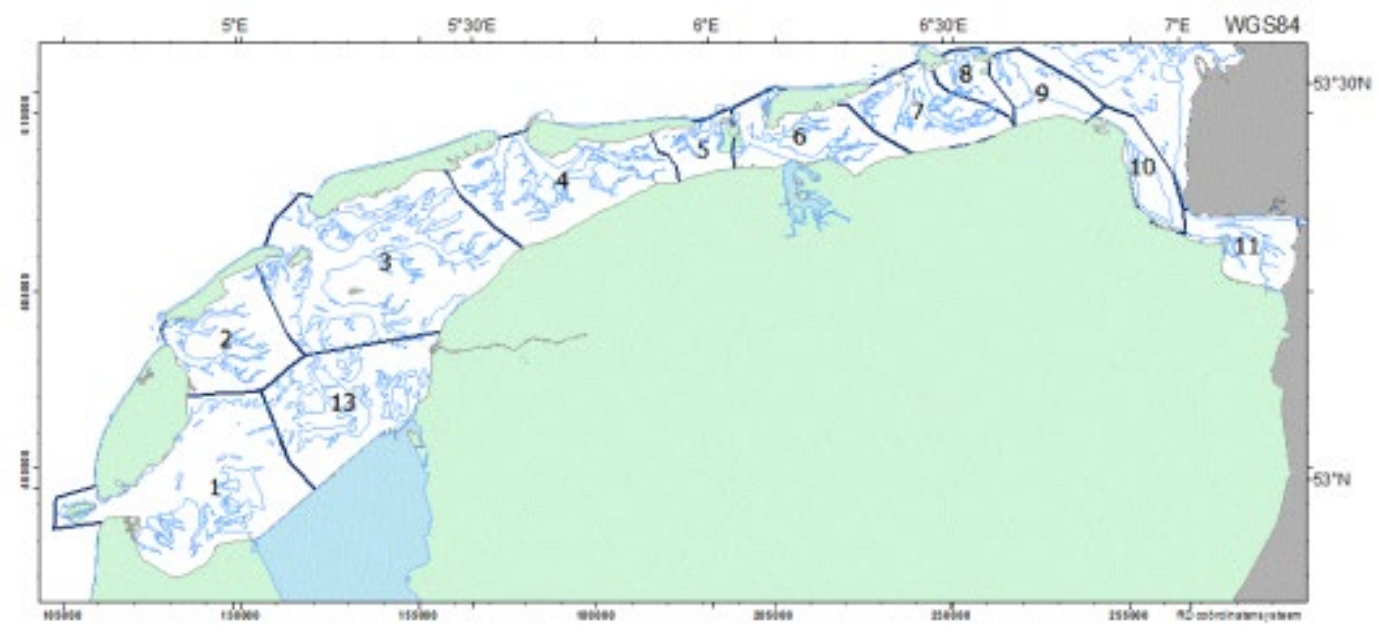

Figuur 12 Verdeling van de Nederlandse Waddenzee in de telgebieden. Bron: https://www.wur.nl/nl/show/Populatie-Gewone-Zeehonden-in-de-Nederlandse-Waddenzee.htm 


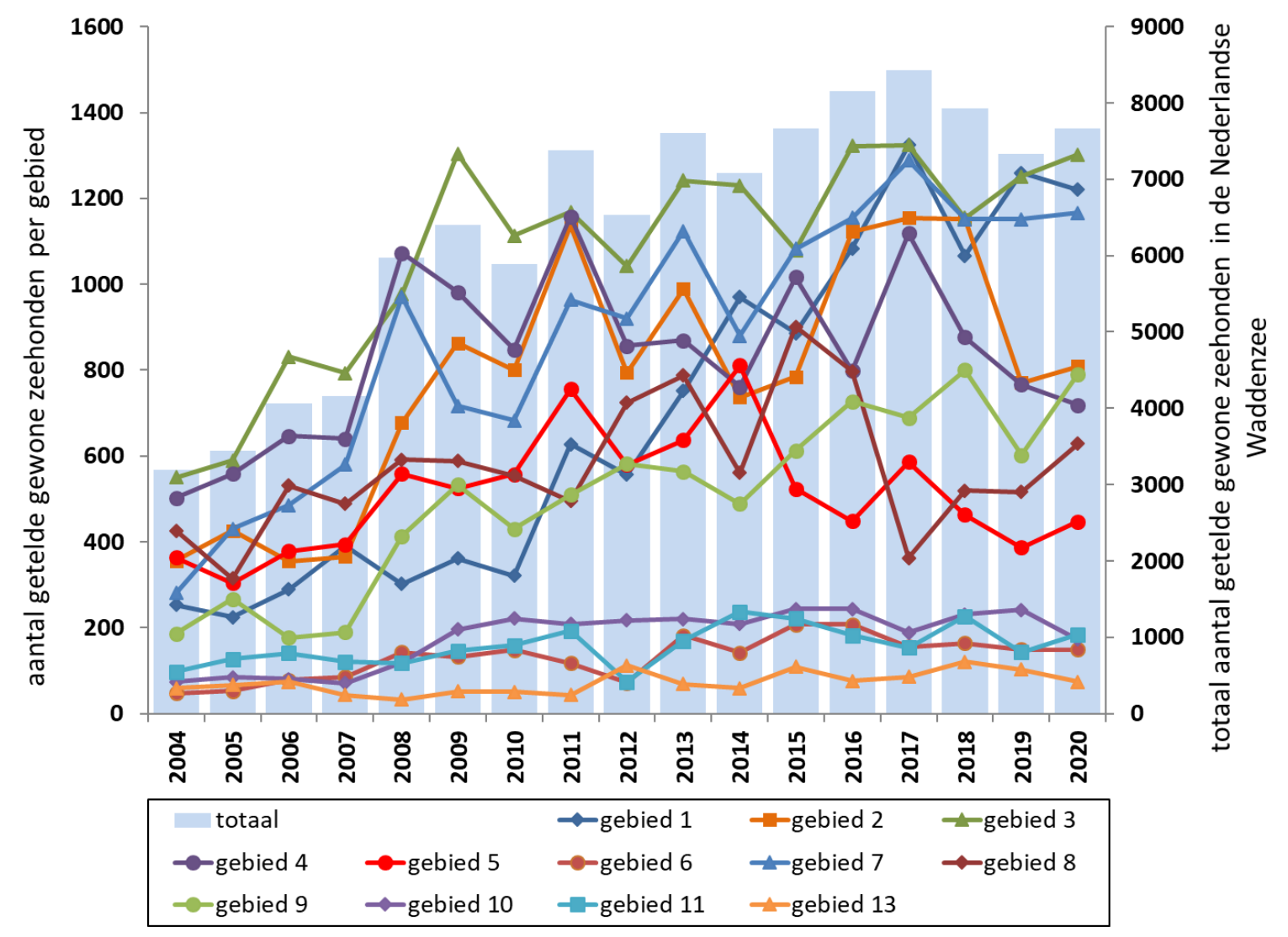

Figuur 13 Aantallen gewone zeehonden geteld in de verschillende gebieden vanaf 2004. Bron: https://www.wur.nl/nl/show/Populatie-Gewone-Zeehonden-in-de-Nederlandse-Waddenzee.htm De ligging van de gebieden is te zien in Figuur 12. 


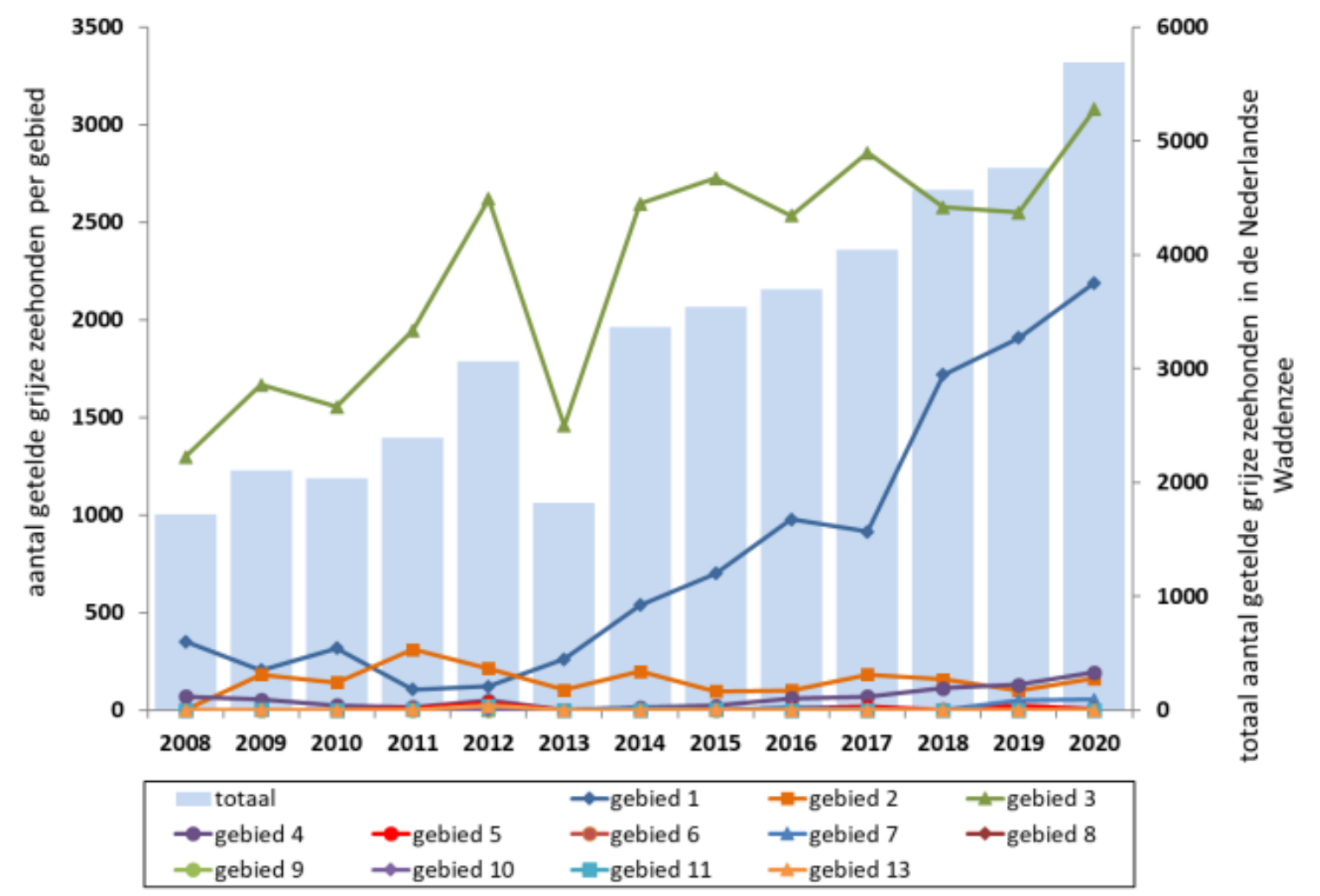

Figuur 14 Aantallen grijze zeehonden geteld in de verschillende gebieden in maart/april vanaf 2008. Bron: https://www.wur.nl/nl/Onderzoek-Resultaten/Onderzoeksinstituten/marine-research/showmarine/Populatie-Grijze-Zeehonden-in-de-Nederlandse-Waddenzee.htm. De ligging van de gebieden is te zien in Figuur 12.

\subsubsection{Gevolgen voor instandhoudingsdoelstellingen}

Voor de drie beschermde zeezoogdiersoorten in Natura 2000-gebied Noordzeekustzone geldt een behoudsdoelstelling ten aanzien van de omvang van het (leef)gebied. Voor de grijze zeehond en de gewone zeehond geldt een behoudsdoelstelling ten aanzien van de kwaliteit van het (leef)gebied, terwijl voor de bruinvis een verbeteropgave geldt. Voor alle drie zeezoogdieren geldt een behoudsdoelstelling ten aanzien van de populatie.

Uit de gegevens van de tellingen van de bruinvissen in het Nederlandse deel van de Noordzee is met de best beschikbare gegevens voor de periode 2010-2019 geen statistisch significante afname of toename te halen, zoals hiervoor is beschreven. Hieruit kan geconcludeerd worden dat de behoudsdoelstelling ten aanzien van de omvang van de populatie door het huidige menselijke gebruik niet in gevaar is. Uit de effectbeoordeling van de Slow Mill-activiteiten in deze PB blijkt dat de omvang van het leefgebied daardoor niet wezenlijk wordt aangetast. Daarnaast zijn er geen redenen om aan te nemen dat de kwaliteit van het leefgebied door de Slow Mill-activiteiten significant zal worden aangetast of dat deze activiteiten een kwaliteitsverbetering in de weg zullen staan. Negatieve gevolgen van de Slow Mill-installatie en bijbehorende werkzaamheden voor de instandhoudingsdoelstelling van de bruinvis worden dan ook uitgesloten.

De populatiegrootte van gewone zeehonden in Nederland blijkt sinds 2012 ongeveer gelijk te blijven en dat geldt ook voor de telgebieden die het meest dichtbij het studiegebied van de Slow Mill liggen. Uit deze PB blijkt dat door de Slow Mill-activiteiten de omvang van het leefgebied van de gewone zeehond niet wordt aangetast en er zijn ook geen redenen te veronderstellen dat de kwaliteit van het leefgebied significant zal worden aangetast. Negatieve gevolgen van de Slow Mill-installatie en bijbehorende werkzaamheden voor de instandhoudingsdoelstelling van de gewone zeehond worden dan ook uitgesloten.

De populatieomvang van de grijze zeehond in Nederland neemt in de afgelopen jaren toe en dat geldt ook voor de telgebieden die het meest dichtbij het studiegebied van de Slow Mill liggen. Uit deze PB 
blijkt dat door de Slow Mill-activiteiten de omvang van het leefgebied van de grijze zeehond niet wordt aangetast, en er zijn ook geen redenen om aan te nemen dat de kwaliteit van het leefgebied significant zal worden aangetast. Negatieve gevolgen van de Slow Mill-installatie en bijbehorende werkzaamheden voor de instandhoudingsdoelstelling van de grijze zeehond worden dan ook uitgesloten.

\subsection{Vogels}

\subsubsection{Globale beoordeling}

Broedvogels: De bontbekplevier, strandplevier en dwergstern komen in het studiegebied niet voor als broedvogels. Dit kan ook te maken hebben met de intensieve recreatie in en rond het plangebied en in het studiegebied. Deze soorten zullen daarom niet worden blootgesteld aan verstoring die wordt veroorzaakt door de werkzaamheden voor het ingraven van de kabel van de Slow Mill-pilotinstallatie. Significante gevolgen voor de instandhoudingsdoelstellingen van deze soorten kunnen worden uitgesloten.

Niet-broedvogels: Onder de niet-broedvogelsoorten zijn er twaalf soorten die in relatief lage aantallen voorkomen in het studiegebied: bergeend, topper, scholekster, kluut, bontbekplevier, zilverplevier, kanoet, drieteenstrandloper, bonte strandloper, rosse grutto, wulp en steenloper. Het studiegebied is van geringe tot marginale betekenis voor deze soorten. Het effect van de tijdelijke verstoring door bovenwatergeluid of optische verstoring door aanwezigheid van mensen, schepen en materieel is verwaarloosbaar. Negatieve gevolgen voor de instandhoudingsdoelstellingen van deze soorten worden dan ook uitgesloten.

De roodkeelduiker, parelduiker, aalscholver, eidereend, zwarte zee-eend en dwergmeeuw komen op open water voor, ook in het studiegebied. De dwergmeeuw pikt voedsel op van het wateroppervlak, waardoor sterfte of verwonding door botsing met de onderwaterdelen van de Slow Mill-pilotinstallatie niet op zal treden. De andere vijf soorten duiken diep naar voedsel (vis of schelpdieren) en kunnen wel botsen met de (bewegende) onderwaterdelen van de Slow Mill-pilotinstallatie. Overige verstoringsfactoren die mogelijk effecten veroorzaken op alle zes vogelsoorten zijn optische verstoring (ontwijking), verstoring door geluid (boven water), verandering golfslag en introductie hard substraat (positief). Vanwege de genoemde potentiële negatieve effecten kunnen negatieve gevolgen voor de instandhoudingsdoelstellingen van deze zes niet-broedvogelsoorten niet worden uitgesloten.

In de volgende paragraaf (6.6.2) wordt nader ingegaan op de betekenis van het studiegebied ten opzichte van het hele Noordzeekustzone-gebied.

\subsubsection{Gedetailleerde beoordeling}

De nadere en gedetailleerdere effectbeoordeling is gericht op de vogelsoorten roodkeelduiker, parelduiker, aalscholver, eider, zwarte zee-eend, dwergmeeuw en kleine mantelmeeuw, en de volgende drukfactoren van de Slow Mill-activiteiten:

- Dood of verwonding door botsing

- Optische verstoring

- Verstoring door geluid (boven water)

De beoordeling is opgezet in de volgorde:

- Gevoeligheid voor drukfactoren van WECs

- Verspreiding, dichtheid en trend

- Gevolgen voor de instandhoudingsdoelstellingen 


\subsubsection{Gevoeligheid van zeevogelpopulaties voor WECs}

\section{Dood of verwonding door botsing}

In de voortoets (Jongbloed et al. (2020) is reeds beschreven dat er verschillende publicaties beschikbaar zijn die wijzen op het potentieel negatieve effect dat duikende vogels botsen met onder water gelegen delen van WECs en daarbij gedood of verwond worden (Grecian et al., 2010; Witt et al., 2012; Furness et al., 2012). Het risico op botsing van duikende vogelsoorten met WECs verschilt waarschijnlijk tussen WEC-typen, en de ontwijkingsvaardigheid varieert afhankelijk van de soort, lichaamsgrootte, leeftijd, het dag-nacht-activiteitspatroon, e.d.. Er zijn echter nauwelijks empirische gegevens beschikbaar. Furness et al. (2012) hebben een semi-kwantitatieve methode ontwikkeld voor de inschatting van de onderhavige effecten op vogelsoorten, die waardevol is en verderop in deze PB zal worden gebruikt voor de relevante vogelsoorten. Volgens Furness et al. (2012) lijken WECs minder gevaarlijk voor vogels dan getijdeturbines, die weer minder gevaarlijk zijn dan windturbines. Furness at al. (2012) stellen dat hun bevindingen kunnen worden geëxtrapoleerd naar WECs in andere gebieden.

\section{Optische verstoring en bovenwatergeluid}

Alle voorgenomen Slow Mill-activiteiten zullen optische verstoring veroorzaken voor vogels en zeezoogdieren. De bouw en ontmanteling van de installatie zullen een kortstondige verstoring geven. De installatie zelf kan gedurende de gehele testperiode optische verstoring veroorzaken. Bij een aantal activiteiten, zoals vaarwerkzaamheden en het leggen van de kabel met bijkomende graafwerkzaamheden, zullen optische verstoring en verstoring door geluid gelijktijdig optreden en is de afzonderlijke bijdrage van elk van deze verstoringsfactoren aan het totale effect niet te bepalen. De beschermde vogelsoorten zijn gevoelig voor verstoring door de bewegingen van mensen, verplaatsing van materieel en door geluid. Tijdens deze werkzaamheden kunnen de aanwezige dieren binnen een soort-specifieke verstoringafstand door beweging tijdelijk verstoord worden en de omgeving van het projectgebied mijden. Na afloop van de werkzaamheden, wanneer de verstoring stopt, kunnen deze dieren het gebied weer gebruiken. Gewenning van de vogels aan een frequente aanwezigheid van mensen en materieel zal mogelijk optreden, met aanzienlijke verschillen tussen soorten en voor sommige soorten ook tussen individuen. De mate van gewenning is niet te voorspellen.

\section{Overall-gevoeligheid voor WECs}

Furness et al. (2012) hebben een semi-kwantitatieve methode ontwikkeld voor de schatting van de gevoeligheid van zeevogelpopulaties voor WECs. Daarvoor hebben ze zeven factoren voor de kwetsbaarheid voor WECs gekozen. Vijf factoren hiervan zijn gescoord op een 1 tot 5 schaal (risk of collision mortality due to structures (risico op dood door botsing met structuren), exclusion from foraging habitat (verdringing uit foerageerhabitat), disturbance by structures (verstoring door structuren), disturbance by ship traffic (verstoring door scheepsverkeer), flexibility in habitat use (flexibiliteit in habitatgebruik)). Daarbij representeert de score 5 een hoge gevoeligheid of impact. De andere twee factoren (benefit from roost platform (profiteren van rustplatform), benefit from fish attraction device effects or biofouling (profiteren van visaantrekking door object of biofouling)) zijn gescoord op een negatieve schaal van 0 tot -2 ( 0 representeert geen effect en -2 representeert een klein voordeel voor vogels van die soort).

De kwetsbaarheid van zeevogels voor WECs in de Schotse wateren is ingeschat door Furness et al. (2012) voor veel soorten (zie Bijlage 11) met scores en de bijbehorende descriptoren, die zijn gegroepeerd in vijf categorieën: zeer hoge kwetsbaarheid; scores boven 400), hoge kwetsbaarheid; scores 301-400), matige kwetsbaarheid; scores 201-300), lage kwetsbaarheid; scores 101-200), zeer lage kwetsbaarheid; scores 0-100) (Bijlage 11). De auteurs vermelden dat de grenzen van deze categorieën arbitrair zijn, maar zijn ontwikkeld om soorten te kunnen rangschikken in groepen die kunnen worden gehanteerd door ontwikkelaars en regelgevers.

Alle vogelsoorten die geselecteerd zijn voor onderhavige PB, behalve de dwergmeeuw, zijn meegenomen door Furness et al. (2012). Men dient zich te realiseren dat de conservation status (beschermingsstatus) van de vogelpopulaties zoals Furness et al. (2012) die hebben meegenomen in hun gevoeligheidsindex, afhankelijk is van de regionale (dus Schotse) situatie. In de Nederlandse Noordzeekust zal die beschermingsstatus voor sommige vogelsoorten anders zijn dan voor de Schotse wateren. De beschermingsstatus is daarom aangepast voor de Nederlandse situatie. Furness et al. 
(2012) gebruiken vier factoren als maat voor conservation status (beschermingsstatus), namelijk: status in relation to the Birds Directive (status in relatie tot de Vogelrichtlijn), percentage of the biogeographic population that occurs in Scotland (percentage van de biogeografische populatie die voorkomt in Schotland), adult survival rate (adulte overleving getal), UK threat status (VK bedreiging status). Voor de effectbeoordeling die wij hier in deze PB doen voor Natura 2000-gebied Noordzeekustzone is een eigen maat beschikbaar die het meest verglijkbaar is met de eerste van de vier factoren die Furness et al. (2012) gebruiken, namelijk de status in de Noordzeekustzone vanwege de Vogelrichtlijn. Voor die status gebruiken wij in deze PB de huidige of recente omvang en trend van de populatie en de instandhoudingsdoelstelling in Natura 2000-gebied Noordzeekustzone en Duinen en Lage Land Texel (zie Bijlage 1 en Bijlage 2).

Tabel 10 Kwetsbaarheid index van vogelsoorten voor WECs gebaseerd op Furness et al. (2012). De scores worden uitgelegd in de hoofdtekst.

\begin{tabular}{|c|c|c|c|c|c|c|c|c|c|c|}
\hline Vogelsoort & \multicolumn{10}{|c|}{ Kwetsbaarheid factoren } \\
\hline & 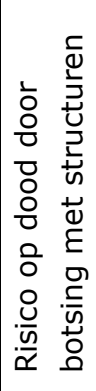 & 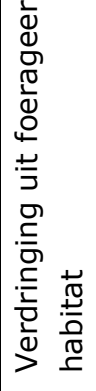 & 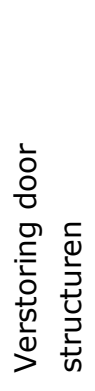 & 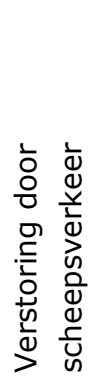 & 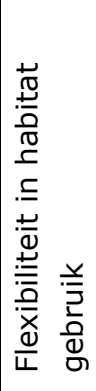 & 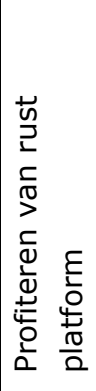 & 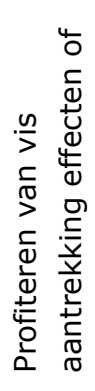 & 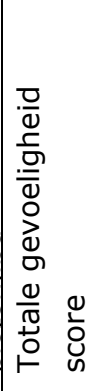 & 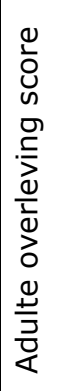 & 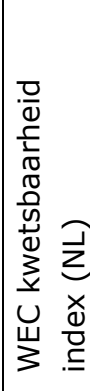 \\
\hline Parelduiker & 3 & 3 & 3 & 5 & 4 & 0 & 0 & 18 & 4 & 72 \\
\hline Roodkeelduiker & 3 & 3 & 3 & 5 & 4 & 0 & 0 & 18 & 3 & 54 \\
\hline Eider & 2 & 2 & 1 & 3 & 4 & -1 & -1 & 10 & 4 & 40 \\
\hline Zwarte zee-eend & 2 & 2 & 2 & 5 & 4 & 0 & 0 & 15 & 2 & 30 \\
\hline Aalscholver & 3 & 2 & 2 & 4 & 3 & -2 & -2 & 10 & 3 & 30 \\
\hline Kleine mantelmeeuw & 1 & 1 & 1 & 2 & 1 & -1 & -1 & 4 & 5 & 20 \\
\hline Kokmeeuw & 1 & 1 & 1 & 2 & 2 & -1 & -1 & 5 & 3 & 15 \\
\hline Stormmeeuw & 1 & 1 & 1 & 2 & 2 & -1 & -1 & 5 & 3 & 15 \\
\hline
\end{tabular}

De roodkeelduiker en de parelduiker hebben een matige kwetsbaarheid voor WECs en de hoogste scores in Tabel 11. De zwarte zee-eend, eider en aalscholver hebben een lage kwetsbaarheid volgens Furness et al. (2012) (zie Bijlage 11) en nemen de middenpositie in Tabel 11 in. De kleine mantelmeeuw heeft een zeer lage kwetsbaarheid voor WECs in de Schotse wateren volgens Furness en neem een lage positie in Tabel 11. Voor de dwergmeeuw is geen inschatting voor gevoeligheid voor WECs gedaan door Furness et al. (2012). Voor deze PB hebben wij daarom gekozen voor meeuwensoorten omdat daarvoor wel een inschatting is gedaan door Furness et al. (2012) en ze bovendien het beste kunnen worden vergeleken met de dwergmeeuw. Hiervoor komen de kokmeeuw en de stormmeeuw in aanmerking. Afgaande op de zeer lage scores voor deze beide meeuwensoorten, wordt ook voor de dwergmeeuw een zeer lage kwetsbaarheid voor WECs verwacht.

\subsubsection{Verspreiding, dichtheid en trend}

Het is van belang zicht te krijgen op de dichtheden van de relevante vogelsoorten in het studiegebied van de Slow Mill. Er zijn een beperkt aantal bruikbare bronnen beschikbaar, namelijk Camphuysen \& Leopold (1994), Camphuysen (2013), Van der Wal et al. (2018), Gyimesi et al. (2018) en de Vogelwerkgroep Texel (Van der Meer et al., 2020). Dichtheidskaarten voor de vogelsoorten uit Van der Wal et al. (2018), Gyimesi et al. (2018) zijn te vinden in Bijlage 9. Kwantitatieve gegevens van de 
dichtheden van alle voor deze PB relevante zeevogelsoorten in het deel voor de Noordzeekust van Texel dat geheel of grotendeels samenvalt met het studiegebied zijn betrokken uit Camphuysen \& Leopold (1994) en de Vogelwerkgroep Texel en staan vermeld in Tabel 12 en Tabel 13.

Tabel 11 Dichtheden van de geselecteerde zeevogelsoorten in het (10 ' L $20^{\prime} \mathrm{L}$ ) vak voor de Noordzeekust van Texel. Gemiddelde dichtheden $\left(\mathrm{n} / \mathrm{km}^{2}\right)$ in 2-maandelijkse perioden. Bron: Camphuysen \& Leopold (1994)

\begin{tabular}{|l|c|c|c|c|c|c|}
\hline Nederlandse naam & Jun-Jul & Aug-Sep & Okt-Nov & Dec-Jan & Feb-Mar & Apr-Mei \\
\hline Roodkeelduiker en Parelduiker & 0 & 0 & $0.1-0.9$ & $0.1-0.9$ & $0.1-0.9$ & 0 \\
\hline Aalscholver & $0.1-0.9$ & $0.1-0.9$ & & 0 & 0 & $0.1-0.9$ \\
\hline Eider & & 0 & $0.1-0.9$ & $0.1-0.9$ & $>4.0$ & $0.1-0.9$ \\
\hline Zwarte zee-eend & $0.1-0.9$ & 0 & $2.0-3.9$ & $0.1-0.9$ & $>4.0$ & $1.0-1.9$ \\
\hline Dwergmeeuw & & 0 & $0.1-0.9$ & 0 & $0.1-0.9$ & 0 \\
\hline Kleine Mantelmeeuw & $0.1-0.9$ & $0.1-0.9$ & $2.0-3.9$ & $0.1-0.9$ & $0.1-0.9$ & $0.1-0.9$ \\
\hline
\end{tabular}

Tabel 12 Resultaten van de vogeltelwaarnemingen van de Vogelwerkgroep Texel bij Paal 20 op Texel in de periode $2015 \mathrm{t} / \mathrm{m} 2019$ voor de geselecteerde zeevogelsoorten weergegeven als jaargemiddelden. Bron: http://www.vwgtexel.nl/waarnemingen

\begin{tabular}{|l|c|c|}
\hline Vogelsoort & $\begin{array}{c}\text { Aantal } \\
\text { waarnemingen }\end{array}$ & $\begin{array}{c}\text { Aantal } \\
\text { exemplaren }\end{array}$ \\
\hline Roodkeelduiker & 66 & 448 \\
\hline Parelduiker & 4 & 4 \\
\hline Aalscholver & 12 & 85 \\
\hline Eider & 24 & 222 \\
\hline Zwarte Zee-eend & 76 & 4113 \\
\hline Dwergmeeuw & 14 & 220 \\
\hline Kleine Mantelmeeuw & 4 & 12 \\
\hline
\end{tabular}

De publicatie Vogels op Texel Jaaroverzicht 2019 van de Vogelwerkgroep Texel 2019 (Van der Meer et al., 2020) bevat informatie over de ruimtelijke en temporele verspreiding van de relevante vogelsoorten met het oog op het studiegebied voor Slow Mill-activiteiten en is hieronder samengevat.

\section{Roodkeelduiker}

Op de Noordzee voor Texel overwinteren ieder jaar veel roodkeelduikers. Precieze aantallen zijn lastig vast te stellen, maar uit zeetrektellingen blijkt dat het mogelijk om 2.000-3.000 vogels gaat; een substantieel aantal. De voorjaarstek vond vooral plaats in maart. Najaarstrek is meer verspreid.

\section{Parelduiker}

Geschat wordt dat er in Nederland 50-150 parelduikers overwinteren (Sovon, 2018). In de afgelopen jaren bijvoorbeeld 3 keer meerdere exemplaren: 17, 7 en 15 exemplaren. Dit betekent dat in sommige jaren een vrij aanzienlijk deel in de omgeving van Texel aanwezig is.

\section{Aalscholver}

Zeer talrijke broedvogel, met 1.272 broedparen. In de duinmeren van de Geul en de Muy broedden resp. 560 en 627 paren en op de kwelder van de Schorren broedden 85 paren. Er zijn foerageervluchten boven de Noordzee.

Eider

Deze soort is algemeen, zowel op de Waddenzee als de Noordzee. De aantallen waren in 2019 het hoogst op de Waddenzee. Op de Noordzee werden op 24 maart 2019 zelfs 649 langs vliegende 
exemplaren geteld vanaf paal 15 . Op de Noordzee waren de aantallen in het najaar lager dan in het voorjaar.

\section{Zwarte zee-eend}

Deze soort werd in alle maanden van het jaar 2019 vastgesteld, vooral op de Noordzee. In januari werden in totaal de meeste exemplaren waargenomen. Het hoogste dagtotaal werd vastgesteld op 24 maart toen 1.624 exemplaren langs paal 15 trokken. In het najaar werd vooral trek waargenomen in oktober met als maximum 869 exemplaren langs paal 15 op 5 oktober 2019.

\section{Dwergmeeuw}

Uit alle maanden kwamen waarnemingen binnen. De helft van het aantal meldingen kwam uit het voorjaar (maart-mei), tegenover een kwart uit het najaar (oktober-november). Het hoogste aantal betrof 483 exemplaren langs de Westerslag op 13 november 2019.

\section{Kleine mantelmeeuw}

Zeer talrijke broedvogel in de duinen en vrij talrijk op kwelders zoals bij de Joost Dorleinkazerne en op de Schorren. Het hoogste aantal betrof 1.737 ex. op 30 juni 2019 langs de Westerslag waarvan het merendeel richting het zuiden vloog.

Er zijn een aantal studies (Leopold et al., 2010; Leopold et al., 2014; Fijn et al., 2019) beschikbaar die aantonen dat er tussen locaties en ook tussen jaren zeer grote variaties kunnen optreden in de aantallen zwarte zee-eenden. Er kunnen, zo maar opeens, als er eens veel schelpdieren liggen, grote aantallen zee-eenden opduiken, op iedere locatie langs de kust. En die worden dan verstoord door de werkzaamheden. Eén van de publicaties heeft betrekking op een grote concentratie van zwarte-zeeeenden bij Texel (Leopold et al., (2010). De locatie van de Slow Mill bij Texel kan dus in de toekomst een belangrijke foerageerlocatie zijn wanneer daar grote concentratie aan scheldieren zal optreden. Het is echter niet te voorspellen of en wanneer dit kan optreden. Ook het belang voor zwarte-zeeeenden van deze locatie ten opzichte van andere locaties in de Noordzeekustzone is niet te voorspellen.

\section{Trend aantallen vogels}

Daarnaast is ook van belang hoe de aantallen vogels in het Natura 2000-gebied zich in de laatste jaren hebben ontwikkeld. Met die informatie is het mogelijk in te schatten of de instandhoudingsdoelstellingen van de vogelsoorten wel of niet zullen worden gehaald en wat hun gevoeligheid is ten aanzien van mogelijk negatieve effecten van nieuwe projecten en plannen in het gebied, zoals het Slow Mill-pilotproject. Voor een aantal vogelsoorten (aalscholver, eider, zwarte zee-eend, kleine mantelmeeuw) zijn trendgrafieken van vogels van Natura 2000-gebied Noordzeekustzone beschikbaar (zie Bijlage 10).

De trend sinds $2007 / 2008$ is een sterke afname voor de eider, een matige afname voor de kleine mantelmeeuw, een onduidelijke trend voor aalscholver en zwarte zee-eend, en een onbekende trend voor roodkeelduiker, parelduiker en dwergmeeuw.

\subsubsection{Gevolgen voor instandhoudingsdoelstellingen}

Voor alle beschermde vogels die in deze PB zijn beoordeeld, gelden behoudsdoelstellingen voor zowel de omvang als de kwaliteit van hun (leef)gebied.

De kwetsbaarheid van de vogelsoorten en hun instandhoudingsdoelstellingen in de Natura 2000gebieden Noordzeekustzone en Lage land van Texel voor de Slow Mill-installatie en bijbehorende werkzaamheden wordt vooral bepaald door de kwetsbaarheid van de soort voor WECs in het algemeen zoals hierboven is ingeschat. Het belang van het gebied rondom de Slow Mill dat wordt weerspiegeld door het voorkomen (dichtheid) van de vogels in dat gebied, alsmede door de voor hen geldende doelstelling in Natura 2000-gebied Noordzeekustzone. Hierop wordt per soort ingegaan. 
De roodkeelduiker heeft een middelmatige kwetsbaarheid voor WECs (Tabel 11). De dichtheid in het studiegebied (Tabel 12) is laag. Negatieve gevolgen van de Slow Mill-installatie en bijbehorende werkzaamheden voor de instandhoudingsdoelstelling van deze soort worden dan ook uitgesloten.

De aalscholver heeft een lage kwetsbaarheid voor WECs (Tabel 11). De dichtheid in het studiegebied (Tabel 12) is laag. Negatieve gevolgen van de Slow Mill-installatie en bijbehorende werkzaamheden voor de instandhoudingsdoelstelling van deze soort worden dan ook uitgesloten.

De eider heeft een lage kwetsbaarheid voor WECs (Tabel 11). De dichtheid in het studiegebied (Tabel 12 ) is laag gedurende het grootste deel van het jaar gering. Negatieve gevolgen van de Slow Millinstallatie en bijbehorende werkzaamheden voor de instandhoudingsdoelstelling van deze soort worden dan ook uitgesloten.

De zwarte zee-eend heeft een lage kwetsbaarheid voor WECs (Tabel 11). De dichtheid in het studiegebied (Tabel 12) zal meestal gering zijn, maar zou incidenteel ook groot kunnen zijn wanneer er op eens bij de locatie van de Slow Mill veel voedsel (schelpdierconcentraties) beschikbaar is. Het belang van het studiegebied ten opzichte van andere deelgebieden in de Noordzeekustzone is niet te voorspellen. Vanwege de lage kwetsbaarheid worden negatieve gevolgen van de Slow Mill-installatie en bijbehorende werkzaamheden voor de instandhoudingsdoelstelling van deze soort echter wel uitgesloten.

De dwergmeeuw heeft waarschijnlijk een zeer lage kwetsbaarheid voor WECs (Tabel 11) en een lage dichtheid in het studiegebied (Tabel 12). Vanwege de waarschijnlijk zeer lage kwetsbaarheid worden negatieve gevolgen van de Slow Mill-installatie en bijbehorende werkzaamheden voor de instandhoudingsdoelstelling van deze soort worden uitgesloten.

De kleine mantelmeeuw heeft een zeer lage kwetsbaarheid voor WECs (Tabel 11). De dichtheid in het studiegebied (Tabel 12) is gedurende het grootste deel van het jaar gering. Vanwege de zeer lage kwetsbaarheid worden negatieve gevolgen van de Slow Mill-installatie en bijbehorende werkzaamheden voor de instandhoudingsdoelstelling van deze soort uitgesloten.

\subsection{Mitigatie}

Er zijn geen mitigerende maatregelen voor de activiteiten voor de Slow Mill nodig omdat uit de effectbeoordeling in de voorgaande paragrafen van dit hoofdstuk blijkt dat significante effecten op de instandhoudingsdoelstellingen niet worden verwacht.

Als voorzorgsmaatregel voor het optreden van enig negatief effect van de installatiewerkzaamheden voor de Slow Mill op zwarte zee-eenden wordt voorgesteld het installeren van de Slow Mill uit te stellen in geval er aanwijzingen zijn dat de locatie op dat moment extra aantrekkelijk is voor zwarte zee-eenden omdat zich daar een grote concentratie aan schelpdieren bevindt waar zwarte zee-eenden graag op foerageren. De aanwijzingen kunnen worden gebaseerd op schelpdiersurvey-gegevens uit een recente rapportages van WMR (Troost et al., 2021).

\subsection{Cumulatie}

In de Noordzeekustzone vinden veel andere menselijke activiteiten plaats, waarvan de meeste al gedurende een langere periode. Deze bestaande menselijke activiteiten zijn beoordeeld op hun effecten op de instandhoudingsdoelstellingen voor het bestaande beheerplan Noordzeekustzone dat loopt over de periode 2016-2022 (Ministerie van Infrastructuur en Milieu, 2016a). Wij hebben geen informatie over andere plannen of projecten die al dan niet gelijktijdig met de Slow Mill-pilot zullen gaan plaatsvinden in, of met invloed op, het studiegebied in de Noordzeekustzone. 
De knelpunten en oplossingsrichtingen voor de voor de PB relevante aangewezen habitatsoorten en vogelsoorten zoals die zijn vermeld in het beheerplan Noordzeekustzone, zijn samengevat in de Tabel 14 en Tabel 15.

Tabel 13 Knelpunten en oplossingsrichtingen voor de aangewezen habitatsoorten van het Natura 20000-gebied Noordzeekustzone, waarvoor in deze PB een gedetailleerde effectbeoordeling is uitgevoerd. Bron: Beheerplan Noordzeekustzone (2016).

\begin{tabular}{|c|c|c|c|c|}
\hline $\mathrm{Nr}$ & Naam habitatsoort & $\begin{array}{c}\text { Behalen doel met } \\
\text { huidige beheerpraktijk? }\end{array}$ & Knelpunten & Oplossingsrichtingen \\
\hline H1095 & Zeeprik & Waarschijnlijk wel & Geen & Niet van toepassing \\
\hline H1099 & Rivierprik & Waarschijnlijk wel & Geen & Niet van toepassing \\
\hline $\mathrm{H} 1103$ & Fint & Waarschijnlijk wel & Geen & Niet van toepassing \\
\hline $\mathrm{H} 1351$ & Bruinvis & Niet & Kwaliteit leefgebied & $\begin{array}{l}\text { Onderzoek impact bijvangst } \\
\text { visserij en onderwatergeluid } \\
\text { en mede op basis daarvan } \\
\text { nemen van maatregelen }\end{array}$ \\
\hline H1364 & Grijze zeehond & Waarschijnlijk wel & Geen & $\begin{array}{c}\text { Niet van toepassing. Vinger } \\
\text { aan de pols vanwege } \\
\text { voortplantingshabitat }\end{array}$ \\
\hline $\mathrm{H} 1365$ & Gewone zeehond & Wel & Geen & Niet van toepassing \\
\hline
\end{tabular}

Tabel 14 Knelpunten, oplossingsrichtingen en aantallen voor relevante aangewezen vogelsoorten van het Natura 20000-gebied Noordzeekustzone, waarvoor in deze PB een gedetailleerde effectbeoordeling is uitgevoerd. Bron: Beheerplan Noordzeekustzone (2016).

\begin{tabular}{|c|c|c|c|c|c|c|}
\hline $\mathrm{Nr}$ & Naam vogel & $\begin{array}{l}\text { Behalen doel } \\
\text { met huidige } \\
\text { prakrijkbeheer }\end{array}$ & Knelpunten & Oplossingsrichtingen & $\begin{array}{c}\text { Huidige } \\
\text { aantallen } \\
\text { (2008/2009 } \\
\text { t/m } \\
\text { 2012/2013) }\end{array}$ & Trend \\
\hline A001 & Roodkeelduiker & $\begin{array}{c}\text { Waarschijnlijk } \\
\text { wel }\end{array}$ & Geen & $\begin{array}{c}\text { Niet van toepassing. } \\
\text { Overigens: } \\
\text { garanderen rustige } \\
\text { condities in } \\
\text { foerageergebieden }\end{array}$ & - & $?$ \\
\hline A002 & Parelduiker & $\begin{array}{c}\text { Waarschijnlijk } \\
\text { wel }\end{array}$ & Geen & Idem & - & $?$ \\
\hline A017 & Aalscholver & $\begin{array}{l}\text { Waarschijnlijk } \\
\text { niet }\end{array}$ & $\begin{array}{c}\text { Kwaliteit/Draagkracht } \\
\text { leefgebieden }\end{array}$ & $\begin{array}{c}\text { Garanderen rustige } \\
\text { condities op en rond } \\
\text { rustplaatsen; } \\
\text { Verduurzamen } \\
\text { visserij, reguleren } \\
\text { scheepvaart, } \\
\text { kustonderhoud }\end{array}$ & 663 & Afnemend \\
\hline A063 & Eider & $\begin{array}{c}\text { Waarschijnlijk } \\
\text { niet }\end{array}$ & $\begin{array}{c}\text { Onvoldoende voedsel } \\
\text { en rust }\end{array}$ & $\begin{array}{l}\text { Verduurzamen } \\
\text { visserij, reguleren } \\
\text { scheepvaart, } \\
\text { kustsuppleties } \\
\text { (transport, } \\
\text { bodemberoering, } \\
\text { luchtvaart) }\end{array}$ & 1374 & Afnemend \\
\hline A065 & $\begin{array}{l}\text { Zwarte zee- } \\
\text { eend }\end{array}$ & $\begin{array}{c}\text { Waarschijnlijk } \\
\text { niet }\end{array}$ & Idem & Idem & 25842 & Afnemend \\
\hline A177 & Dwergmeeuw & Onduidelijk & Geen & Niet van toepassing & - & Fluctuerend \\
\hline
\end{tabular}


In het beheerplan Noordzeekustzone dat loopt over de periode 2016-2022 zijn de soorten die hun instandhoudingsdoelstelling onder het huidige beheer niet of waarschijnlijk niet zullen halen de bruinvis en de aalscholver vanwege het knelpunt kwaliteit leefgebied en de eider en de zwarte zeeeend vanwege het knelpunt reguleren scheepvaart. Hierbij moet wel worden opgemerkt dat we ten tijde van het opstellen van deze PB (half 2021) een aantal jaren verder zijn dan het jaar waarin het beheerplan werd gepubliceerd (2016). Er is nu nieuwe informatie beschikbaar over de trend van de soorten. Voor de aalscholver is de trend in de Noordzeekustzone onzeker in de periode 2007/20082018/2019 (zie Bijlage 10), terwijl de trend eerder in de tijd afnemend was (Tabel 15). De Slow Millactiviteiten zouden potentieel een bijdrage aan die knelpunten voor die instandhoudingsdoestellingen kunnen hebben vanwege het type verstoring dat de Slow Mill-activiteiten kunnen geven. Dit wordt echter niet verwacht omdat de effecten van de Slow Mill-activiteiten in deze PB zijn beoordeeld als verwaarloosbaar of waarschijnlijk zeer gering. De bijdrage daarvan aan de cumulatie met andere activiteiten is daarom op basis van de huidige beschikbare informatie te beschouwen als verwaarloosbaar. 


\subsection{Overzicht gevolgen voor instandhoudingsdoelstellingen}

De resultaten van de PB zijn samengevat in Tabel 16 en tekstueel in onderstaande paragrafen.

Tabel 15 Overzicht van het eindresultaat van de passende beoordeling van de effecten die van de verschillende verstoringsfactoren als gevolg van de activiteiten voor de Slow Mill-pilotinstallatie kunnen uitgaan op instandhoudingsdoelen van de Noordzeekustzone

\begin{tabular}{|c|c|c|c|c|c|c|c|c|c|c|c|c|}
\hline Instandhoudingsdoelen & 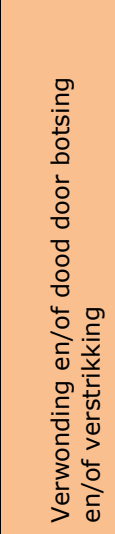 & 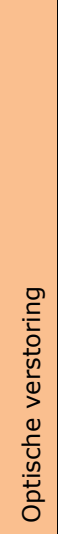 & 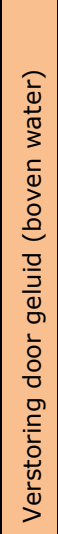 & 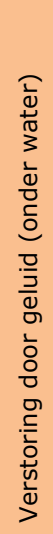 & $\begin{array}{l}\frac{0}{0} \\
\frac{\pi}{4} \\
\frac{4}{0} \\
0 \\
0 \\
0 \\
\frac{5}{1} \\
\frac{0}{0} \\
\frac{0}{0} \\
\frac{\pi}{0} \\
>\end{array}$ & 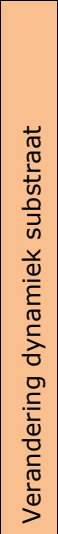 & 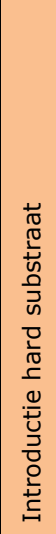 & 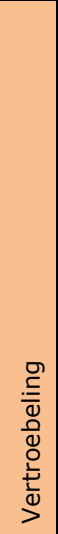 & 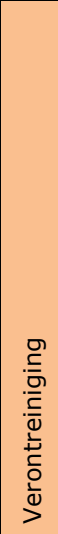 & 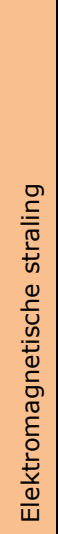 & 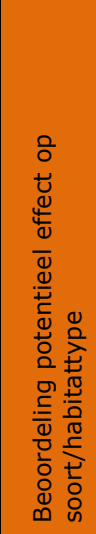 & 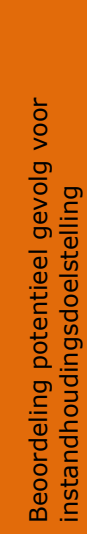 \\
\hline H1110B - Permanent overstroomde zandbanken & & & & & $\mathrm{v}$ & $\mathrm{v}$ & $x$ & $v$ & $\mathrm{~V}$ & & V & $U$ \\
\hline H1140B - Slik- en zandplaten & & & & & $x$ & $\mathrm{x}$ & & & & & $\mathrm{V}$ & $U$ \\
\hline H1310A - Zilte pionierbegroeiingen (zeekraal) & & & & & & & & & & & $\mathrm{G}$ & $\mathrm{U}$ \\
\hline H1310B - Zilte pionierbegroeiingen (zeevetmuur) & & & & & & & & & & & $\mathrm{G}$ & $U$ \\
\hline H1330A - Schorren en zilte graslanden (buitendijks) & & & & & & & & & & & $\mathrm{G}$ & $\mathrm{U}$ \\
\hline H2110 - Embryonale duinen & & & & & & & & & & & $\mathrm{G}$ & $\mathrm{U}$ \\
\hline H2190B - Vochtige duinvalleien (kalkrijk) & & & & & & & & & & & $\mathrm{G}$ & $\mathrm{U}$ \\
\hline H1095 - Zeeprik & $\mathrm{x}$ & & & $\mathrm{v}$ & & & $\mathrm{V}$ & & & $\mathrm{v}$ & $\mathrm{V}$ & $\mathrm{U}$ \\
\hline H1099 - Rivierprik & $\mathrm{x}$ & & & $\mathrm{v}$ & & & $\mathrm{v}$ & & & $\mathrm{v}$ & $\mathrm{V}$ & $\mathrm{U}$ \\
\hline H1103 - Fint & $\mathrm{x}$ & & & $x$ & & & $\mathrm{v}$ & & & $\mathrm{v}$ & $\mathrm{V}$ & $\mathrm{U}$ \\
\hline H1351 - Bruinvis & $x$ & $?$ & & $x$ & & & $\mathrm{v}$ & & & $\mathrm{v}$ & $\mathrm{V}$ & $U$ \\
\hline H1364 - Grijze zeehond & $x$ & $?$ & & $x$ & & & $\mathrm{v}$ & & & $\mathrm{v}$ & V & $\mathrm{U}$ \\
\hline H1365 - Gewone zeehond & $x$ & $?$ & & $x$ & & & $\mathrm{v}$ & & & $\mathrm{v}$ & $\mathrm{V}$ & $\mathrm{U}$ \\
\hline A137 - Bontbekplevier & & $\mathrm{x}$ & $x$ & & & & & & & & $\mathrm{G}$ & $\mathrm{U}$ \\
\hline A138 - Strandplevier & & $x$ & $\mathrm{x}$ & & & & & & & & $\mathrm{G}$ & $\mathrm{U}$ \\
\hline A195 - Dwergstern & & $\mathrm{x}$ & $\mathrm{x}$ & & $\mathrm{v}$ & $\mathrm{V}$ & $\mathrm{v}$ & & $\mathrm{V}$ & & $\mathrm{G}$ & $U$ \\
\hline A001 - Roodkeelduiker & $x$ & $\mathrm{x}$ & $\mathrm{x}$ & & $\mathrm{v}$ & $\mathrm{v}$ & $\mathrm{v}$ & & $\mathrm{v}$ & & $\mathrm{V}$ & $U$ \\
\hline A002 - Parelduiker & $x$ & $x$ & $x$ & & $\mathrm{v}$ & $\mathrm{V}$ & $\mathrm{v}$ & & $\mathrm{V}$ & & $\mathrm{V}$ & $U$ \\
\hline A017 - Aalscholver & $\mathrm{x}$ & $\mathrm{v}$ & $\mathrm{x}$ & & $\mathrm{v}$ & $\mathrm{V}$ & $\mathrm{v}$ & & $\mathrm{v}$ & & $\mathrm{V}$ & $\mathrm{U}$ \\
\hline A048 - Bergeend & & $\mathrm{v}$ & $\mathrm{x}$ & & & & & & & & $\mathrm{V}$ & $U$ \\
\hline A062 - Topper & $x$ & $\mathrm{x}$ & $\mathrm{x}$ & & $\mathrm{v}$ & $\mathrm{V}$ & $\mathrm{v}$ & & $\mathrm{V}$ & & $\mathrm{V}$ & $\mathrm{U}$ \\
\hline A063 - Eider & $x$ & $x$ & $x$ & & $\mathrm{v}$ & $\mathrm{v}$ & $\mathrm{v}$ & & $\mathrm{v}$ & & $\mathrm{V}$ & $U$ \\
\hline A065 - Zwarte zee-eend & $x$ & $\mathrm{x}$ & $x$ & & $\mathrm{v}$ & $\mathrm{v}$ & $\mathrm{v}$ & & $\mathrm{v}$ & & $\mathrm{V}$ & $U$ \\
\hline A130 - Scholekster & & $\mathrm{x}$ & $\mathrm{x}$ & & & & & & & & $\mathrm{V}$ & $\mathrm{U}$ \\
\hline A132 - Kluut & & $x$ & $x$ & & & & & & & & $\mathrm{~V}$ & $U$ \\
\hline A137 - Bontbekplevier & & $x$ & $x$ & & & & & & & & $\mathrm{~V}$ & $\mathrm{U}$ \\
\hline A141 - Zilverplevier & & $x$ & $x$ & & & & & & & & V & $\mathrm{U}$ \\
\hline A143 - Kanoet & & $\mathrm{x}$ & $\mathrm{x}$ & & & & & & & & $\mathrm{V}$ & $U$ \\
\hline A144 - Drieteenstrandloper & & $\mathrm{x}$ & $\mathrm{x}$ & & & & & & & & $\mathrm{V}$ & $U$ \\
\hline A149 - Bonte strandloper & & $\mathrm{x}$ & $\mathrm{x}$ & & & & & & & & $\mathrm{V}$ & $U$ \\
\hline A157 - Rosse grutto & & $x$ & $\mathrm{x}$ & & & & & & & & $\mathrm{V}$ & $U$ \\
\hline A160 - Wulp & & $x$ & $x$ & & & & & & & & $\mathrm{~V}$ & $U$ \\
\hline A169 - Steenloper & & $\mathrm{V}$ & $x$ & & & & & & & & $\mathrm{~V}$ & $\mathrm{U}$ \\
\hline A177 - Dwergmeeuw & $x$ & $\mathrm{x}$ & $\mathrm{x}$ & & $\mathrm{v}$ & $\mathrm{v}$ & & $\mathrm{v}$ & $\mathrm{v}$ & & $\mathrm{V}$ & $\mathrm{U}$ \\
\hline
\end{tabular}

Legenda

\begin{tabular}{|l|l|}
\hline Weergave & Effect van verstoringsfactor \\
\hline & Geen blootstelling \\
\hline $\mathrm{v}$ & Verwaarloosbaar effect \\
\hline $\mathrm{x}$ & Potentieel effect \\
\hline $\boldsymbol{P}$ & Onbekend effect \\
\hline
\end{tabular}

\begin{tabular}{|l|l|}
\hline Weergave & Effect van alle verstoringsfactoren samen \\
\hline G & Geen effect \\
\hline V & Verwaarloosbaar effect \\
\hline P & Potentieel effect \\
\hline
\end{tabular}

\begin{tabular}{|l|l|}
\hline Weergave & Effectbeoordeling instandhoudingsdoelen \\
\hline$U$ & Significante effecten worden uitgesloten \\
\hline$P$ & Significante effecten kunnen niet worden uitgesloten \\
\hline
\end{tabular}


Het resultaat van de toetsing van eventuele effecten van de Slow Mill-pilotinstallatie op overige soorten die voorkomend op bijlage IV van de habitatrichtlijn, bijlage II van Bern en/of bijlage I van Bonn) die bovendien bekend zijn als regelmatige gast of regelmatige voortplanter op het Nederlands Continentaal Plat en waarschijnlijk ook in het studiegebied kunnen voorkomen, is dat:

- effecten worden uitgesloten voor vijf vleermuissoorten (laatvlieger, gewone dwergvleermuis, noordse vleermuis, rosse vleermuis, ruige dwergvleermuis);

- $\quad$ effecten zijn niet aannemelijk voor vier vissoorten (elft, houting, steur, zalm) en hun populaties.

Er worden geen effecten op habitattypen en soorten van het Natura 2000-gebied Duinen en Lage Land Texel verwacht omdat de projectactiviteiten zich bevinden buiten de begrenzing van dat gebied en geen externe werking van verstorende projectactiviteiten wordt verwacht. 


\section{Stikstofdepositie}

De geplande activiteiten van de Slow Mill pilot Texel zijn te verdelen in een bouwfase, een operationele fase en een ontmantelingsfase. Elias Consulting heeft in opdracht van de initiatiefnemer Slow Mill Sustainable Power BV per fase de stikstofdepositie berekend met de AERIUS Calculator 2020 (releasedatum 15 oktober 2020) (https://calculator.aerius.nl/calculator/).

Ten opzichte van de berekeningen voor de voortoets zijn de activiteiten nu beperkt tot het, volgens de initiatiefnemer, meest realistische uitvoeringsscenario, en zullen de graafwerkzaamheden nu worden uitgevoerd met een graafmachine die zo min mogelijk stikstofemissies heeft.

De invoergegevens met bron sector, scheepstype, voertype en de rekenresultaten van de AERIUS Calculator voor de bouwfase, operationele fase en ontmantelingsfase van Elias Consulting $(2021 a, b, c)$ staan in Bijlage 12.

De mobiele werktuigenbenadering is toegepast. Voor de graafwerkzaamheden zal een LPGaangedreven graafmachine worden gebruikt (bouwjaar 2019, 130-560 kW, Stage V). Aangenomen wordt dat de vaarbewegingen deels tegen het heersende scheepvaartverkeer wegvallen.

Het resultaat met het oog op het onderhavige natuurgebieden is dat de berekening met de AERIUStool betreffende de stikstofemissie in de bouwfase, operationele fase en ontmantelingsfase van de Slow Mill-pilot geen depositieresultaten heeft opgeleverd boven 0,00 mol/ha/jr.

Op basis van deze gegevens kan voor de onderhavige PB de conclusie worden getrokken dat significante ecologische effecten van stikstof op de natuurgebieden door de Slow Mill pilot kunnen worden uitgesloten. 


\section{Conclusies}

De voorgenomen activiteiten voor de Slow Mill-pilotinstallatie in de verschillende fases zijn geanalyseerd wat betreft hun effecten op de Natura 2000-instandhoudingsdoelstellingen van habitats en soorten. Dat is gedaan op basis van de beschikbare kennis en informatie. Echter doordat WECs zoals de Slow Mill-pilotinstallatie nog volop in ontwikkeling zijn, met een beperkt aantal kleine toepassingen, zijn er nog veel onzekerheden omtrent het optreden van effecten en is er relatief veel expert judgement toegepast in deze PB. Daarbij is rekening gehouden met het belang van het studiegebied in relatie tot de hele Noordzeekustzone, en de geringe omvang van het pilot-project.

Wat betreft het Natura 2000-gebied Noordzeekustzone worden significante gevolgen van de Slow Millpilotinstallatie uitgesloten voor de volgende instandhoudingsdoelen:

- zeven habitattypen (H1110B, H1140B, H1310A, H1310B, H1330A, H2110, H2190B);

- drie broedvogelsoorten (bontbekplevier, strandplevier en dwergstern);

- twaalf niet-broedvogelsoorten (bergeend, topper, scholekster, kluut, bontbekplevier, zilverplevier, kanoet, drieteenstrandloper, bonte strandloper, rosse grutto, wulp en steenloper).

en zijn significante gevolgen voor de instandhoudingsdoelstellingen niet aannemelijk voor:

- drie trekvissoorten (zeeprik, rivierprik en fint);

- drie zeezoogdiersoorten (gewone zeehond, grijze zeehond, bruinvis);

- zes niet-broedvogelsoorten (roodkeelduiker, parelduiker, aalscholver, eidereend, zwarte zeeeend en dwergmeeuw).

Vanwege de bescherming van overige soorten (voorkomend op bijlage IV van de habitatrichtlijn, bijlage II van Bern en/of bijlage I van Bonn) die bovendien bekend zijn als regelmatige gast of regelmatige voortplanter op het NCP en waarschijnlijk ook in het studiegebied kunnen voorkomen, is eveneens getoetst op de eventuele effecten van de Slow Mill-pilotinstallatie. De conclusies zijn dat:

- $\quad$ effecten worden uitgesloten voor vijf vleermuissoorten (laatvlieger, gewone dwergvleermuis, noordse vleermuis, rosse vleermuis, ruige dwergvleermuis);

- effecten niet aannemelijk zijn voor vier vissoorten (elft, houting, steur, zalm) en hun populaties.

Er worden geen effecten op habitattypen en soorten van het Natura 2000-gebied Duinen en Lage Land Texel verwacht omdat de projectactiviteiten zich bevinden buiten de begrenzing van dat gebied en geen externe werking van verstorende projectactiviteiten wordt verwacht.

Er zijn geen mitigerende maatregelen voor de activiteiten voor de Slow Mill nodig omdat uit de effectbeoordeling blijkt dat significante effecten op de instandhoudingsdoelstellingen niet worden verwacht.

De cumulatie van effecten behoeft door de voorgenomen activiteiten rondom de Slow Mill niet te worden geanalyseerd, omdat de effecten van de Slow Mill met de best beschikbare informatie, afhankelijk van de soort of habitat, worden ingeschat als afwezig, verwaarloosbaar of zeer gering.

De stikstofberekeningen met de AERIUS Calculator zijn door de initiatiefnemer uitgevoerd en aangereikt. Deze berekeningen hebben geen depositieresultaten opgeleverd boven 0,00 mol/ha/jr. Op basis van deze gegevens kan voor onderhavige PB de conclusie worden getrokken dat significante ecologische effecten van stikstof op de natuurgebieden door de Slow Mill pilot kunnen worden uitgesloten. 


\section{Kwaliteitsborging}

Wageningen Marine Research beschikt over een ISO 9001:2015 gecertificeerd kwaliteitsmanagementsysteem. Dit certificaat is geldig tot 15 december 2021. De organisatie is gecertificeerd sinds 27 februari 2001. De certificering is uitgevoerd door DNV GL. 


\section{Literatuur}

Aarts, G., J. Cremer, R. Kirkwood, J.T. van der Wal, J. Matthiopoulos \& S. Brasseur (2016). Spatial distribution and habitat preference of harbour seals (Phoca vitulina) in the Dutch North Sea. Wageningen University \& Research centre, Wageningen Marine Research, Wageningen Marine Research report number C118/16, 43 pageshttp://dx.doi.org/10.18174/400306

Au, W.W.L. (1993). The Sonar of Dolphins (Springer-Verlag, New York).

Baptist, M. \& M.F. Leopold (2018). Pilotstudie GPS-trackers grote sterns van Utopia, Texel 2018 Wageningen University \& Research report C095/18. Wageningen Marine Research, Den Helder.

Bergström, L., F. Sundqvist \& U. Bergstrom (2013). Effects of an offshore wind farm on temporal and spatial patterns in the demersal fish community. Marine Ecology Progress Series, 2013. 485: p. 199210.

Besluit Milieueffectrapportage, geldend van 01-07-2018 t/m heden.

https://wetten.overheid.nl/BWBR0006788/2018-07-01 [laatst geraadpleegd: augustus 2020]

Boshamer J.P.C. \& J.P. Bekker (2008). Nathusius' pipistrelles (Pipistrellus nathusii) and other species of bats on offshore platforms in the Dutch sector of the North Sea. Lutra 200851 (1): 17-36.

Braekevelt, C.R. (1986). Fine structure of the tapetum cellulosum of the grey seal (Halichoerus grypus). Acta Anat (Basel). 127, 81-87.

Brasseur, S., Schop, J., Cremer, J. \& Aarts, G. (2019). Harbour seal monitoring and evaluation for the Luchterduinen offshore windfarm. doi:10.18174/461959

Buscaino, G., G. Mattiazzo, G. Sannino, E. Papale, G. Bracco, R. Grammauta, A. Carillo, J.M. Kenny, N. De Cristofaro, M. Ceraulo \& S. Mazzola (2019). Acoustic impact of a wave energy converter in Mediterranean shallow waters. Scientific Reports volume 9, Article number: 9586 (2019).

Camphuysen, C.J. \& M.F. Leopold (1994). Atlas of seabirds in the southern North Sea. IBN Research Report 94/6, NIOZ-Report 1994-8, Institute for Forestry and Nature Research, Dutch Seabird Group and Netherlands Institute for Forest Research, Texel, 1-126 pp.

Camphuysen, C.J. (2013) A historical ecology of two closely related gull species (Laridae). PhD Thesis University of Groningen.

Contardo, S. (2018). In situ observations and simulations of coastal wave field transformation by wave energy converters. Coastal Engineering. 140: 175-188.

Copping, A. (2020). OES-Environmental 2020 State of the Science Report: Environmental Effects of Marine Renewable Energy Development Around the World. Report for Ocean Energy Systems (OES).

Copping, A., H. Battey, J. Brown-Saracino, M. Massaua \& C. Smith (2014). An international assessment of the environmental effects of marine energy development. Ocean \& Coastal Management 99 (2014) 3e13.

Dankers, N. \& J. Zegers, 1985. Maatregelen ter voorkoming van verdrinking van zeehonden en hun effecten op de visvangst in harderfuiken. RIN-rapport 85/15. Rijksinstituut voor Natuurbeheer, Texel, $10 \mathrm{pp}$.

De Jong M.L., C.J. Smit \& M.F. Leopold (2010). Aantallen en verspreiding van eiders, toppers en zeeeenden in de winter van 2009-2010 in de Waddenzee en de Noordzeekustzone, Den Burg. Imares Rapport C160/10.

Dehnhardt, G., Mauck, B., Hanke, W., Bleckmann, H. (2001). Hydrodynamic Trail-Following in Harbor Seals (Phoca vitulina) Science 293, 102-104

Elias Consulting (2021a). AERIUS Calculator rekenresultaten. Vaar- en graafwerk, bouwfase. Datum berekening: 15 juni 2021. Rechtspersoon: Slow Mill Sustainable Power BV. Inrichtingslocatie: 4 km 
ten westen van Texel (Paal 19), 1796AA Texel. Omschrijving: Pilot Slow Mill. AERIUS-kenmerk RoJwKnefvSdc.

Elias Consulting (2021b). AERIUS Calculator rekenresultaten. Vaarwerk; operationele fase. Datum berekening: 15 juni 2021. Rechtspersoon: Slow Mill Sustainable Power BV. Inrichtingslocatie: $4 \mathrm{~km}$ ten westen van Texel (Paal 19), 1796AA Texel. Omschrijving: Pilot Slow Mill. AERIUS-kenmerk S3gLRTA9pyCM.

Elias Consulting (2021c). AERIUS Calculator rekenresultaten. Vaar- en graafwerk, ontmantelingsfase. Datum berekening: 15 juni 2021. Rechtspersoon: Slow Mill Sustainable Power BV. Inrichtingslocatie: 4 $\mathrm{km}$ ten westen van Texel (Paal 19), 1796AA Texel. Omschrijving: Pilot Slow Mill. AERIUS-kenmerk RZKBFW2ioVTC.

Fijn, R.C., F.A. Arts, J.W. de Jong, D. Beuker, E.L. Bravo Rebolledo, B.W.R. Engels, M. Hoekstein, RJ. Jonkvorst, S. Lilipaly, M. Sluijter, K.D. van Straalen \& P.A. Wolf (2019). Verspreiding, abundantie en trends van zeevogels en zeezoogdieren op het Nederlands Continentaal Plat in 2018-2019. RWSCentrale Informatievoorziening BM 19.23. Bureau Waardenburg Rapportnr. 19-258. Bureau Waardenburg \& Deltamilieu Projecten, Culemborg.

Fijn, R.C., Leopold, M.F., Dirksen, S., Arts, F., Asch, M. van; Baptist, M.J.; Craeymeersch, J.A.M.; Engels, B., Horssen, P. van, Jong, J. de; Perdon, K.J., Zee, E.M. \& van der, Ham, N. (2017). Een onverwachte concentratie van Zwarte Zee-eenden in de Hollandse kustzone in een gebied met hoge dichtheden van geschikte schelpdieren. Limosa 90 (2017)3. - ISSN 0024-3620 - p. 97 - 117.

Furness, R.W., Wade, H.M., Robbins, A.M.C. \& Masden, E.A. (2012). Assessing the sensitivity of seabird populations to adverse effects from tidal stream turbines and wave energy devices ICES Journal of Marine Science. doi.org/10.1093/icesjms/fss131

Galatius A., Brackmann J., Brasseur S., Diederichs B., Jeß A., Klöpper S., Körber P., Schop J., Siebert U., Teilmann J., Thøstesen B. \& Schmidt B. (2020). Trilateral surveys of Harbour Seals in the Wadden Sea and Helgoland in 2020. Common Wadden Sea Secretariat, Wilhelmshaven, Germany.

Geelhoed S.C.V. \& Scheidat M. (2018). Abundance of harbour porpoises (Phocoena phocoena) on the Dutch Continental Shelf, aerial surveys 2012-2017. Lutra 61(1): 127-136.

Geelhoed S.C.V., Scheidat M., van Bemmelen R.S.A. \& Aarts G. (2013). Abundance of harbour porpoises (Phocoena phocoena) on the Dutch Continental Shelf, aerial surveys in July 2010-March 2011. Lutra 56(1): 45-57.

Geelhoed, S., Janinhoff, N., Lagerveld, S., \& Verdaat, H. (2020). Marine mammal surveys in Dutch North Sea waters in 2019. doi:10.18174/515228

Gill, A.B., M. Bartlett \& F. Thomsen (2012). Potential interactions between diadromous fishes of U.K. conservation importance and the electromagnetic fields and subsea noise from marine renewable energy developments. Journal of Fish Biology, 2012. 81(2): p. 664-695

Gilles A., Viquerat S., Becker E.A., Forney K.A., Geelhoed S.C.V., Haelters J., Nabe-Nielsen J., Scheidat M., Siebert U., Sveegaard S., van Beest F.M., van Bemmelen R. \& Aarts G. (2016). Seasonal habitat-based density models for a marine top predator, the harbor porpoise, in a dynamic environment. Ecosphere7 (6):e01367. 10.1002/ecs2.1367

Grecian, W.J., R. Inger, M.J. Attrill, S. Bearshop, B.J. Godley, M.J. Witt \& S.C. Votier (2010). Potential impacts of wave-powered marine renewable energy installations on marine birds. Ibis (2010), 152, 683-697.

Groen, P. \& R. Dorrestein (1976). Zeegolven. KNMI Publicatienummer 111.11

Gyimesi, A., J.W. de Jong, A. Potiek \& E.L. Bravo Rebolledo (2018). Actualisatie van KEC vogelaanvaring berekeningen volgens Routekaart 2030. Rapportnr. 18-290. Bureau Waardenburg, Culemborg.

Haikonen, K., J. Sundberg \& M. Leijon (2013). Characteristics of the Operational Noise from Full Scale Wave Energy Converters in the Lysekil Project: Estimation of Potential Environmental Impacts. Energies 2013, 6, 2562-2582; doi:10.3390/en6052562. 
Hammond P.S., Macleod K., Berggren P., Borchers D.L., Burt M.L., Cañadas A., Desportes G., Donovan G.P., Gilles A., Gillespie D., Gordon J., Hedley S., Hiby L., Kuklik I., Leaper R., Lehnert K., Leopold M., Lovell P., Øien N., Paxton C., Ridoux V., Rogan E., Samarra F., Scheidat M., Sequeira M., Siebert U., Skov H., Swift R., Tasker M.L., Teilmann J., Van Canneyt O. \& Vázquez J.A. (2013). Cetacean abundance and distribution in European Atlantic shelf waters to inform conservation and management. Biological Conservation, 164: 107-122.

Hutchison, Z., Sigray, P., He, H., Gill, A. B., King, J., \& Gibson, C. (2018). Electromagnetic Field (EMF) Impacts on Elasmobranch (shark, rays, and skates) and American Lobster Movement and Migration from Direct Current Cables. Sterling (VA): US Department of the Interior, Bureau of Ocean Energy Management. OCS Study BOEM, 3.

Jak, R., van Bemmelen, R., van Duin, W., Geelhoed, S., \& Tamis, J. (2014a). Natura 2000-doelen in de Noordzeekustzone. Van doelen naar opgaven voor natuurbescherming. Wageningen Marine Research. Rapport C050/11a.

Jak, R., van Bemmelen, R., van Duin, W., Geelhoed, S., \& Tamis, J. (2014b). Natura 2000-doelen in de Noordzeekustzone. Van doelen naar opgaven voor natuurbescherming. Bijlagerapport.

Wageningen. Marine Research. Rapport C123/14.

Jongbloed R.H., J.T. van der Wal, J.E. Tamis, R.G. Jak, S.I. Jonker, B.J.H. Koolstra \& J.H.M. Schobben (2011). Nadere effectenanalyse Natura 2000-gebieden Waddenzee en Noordzeekustzone. Niet Nbwetvergund gebruik. IMARES rapport C170/11, ARCADIS rapport 057990726:B

Jongbloed, R., M. Keur, R. Jak, M. Scholl (2020). Slow Mill pilot Texel Voortoets Wet natuurbescherming. Wageningen Marine Research rapport C072/20.

Jonge Poerink B., S. Lagerveld \& H. Verdaat (2013). Pilot study, Bat activity in the Dutch offshore wind farm, OWEZ and PAWP. IMARES report number C026/13 / tFC report number 20120402.

Joy, R., Wood J. D., Sparling, C. E. Tollita, D. J. Copping, A. E., and McConnell, B J. (2018). Empirical measures of harbor seal behavior and avoidance of an operational tidal turbine. Marine Pollution Bulletin 136, 92-106.

Kastelein, R. A., van der Heul, S., Verboom, W. C, Triesscheijn, R.J.V., \& Vaughan- Jennings, N. (2006a). The influence of underwater data transmission sounds on the displacement of captive harbour seals (Phoca vitulina), Marine Environmental Research 61, 19-39.

Kastelein, R. A., Verboom, W. C., Jennings, N., de Haan, D., van der Heul, S. (2008). The influence of 70 and $120 \mathrm{kHz}$ tonal signals on the behavior of harbor porpoises (Phocoena phocoena) in a floating pen, Marine Environmental Research 66, 319-326.

http://dx.doi.org/10.1016/j.marenvres.2008.05.005

Kastelein, R.A. Helder-Hoek, L., Gransier, R., Terhune, J.M., Jennings, N. \& de Jong, C.A.F. (2015). Hearing thresholds of harbor seals (Phoca vitulina) for playbacks of seal scarer signals, and effects of the signals on behavior, Hydrobiologia 756, 75-88. DOI: 10.1007/s10750-014- 2152-6

Kastelein, R.A. Rippe, T., Vaughan, N., Schooneman, N.M., Verboom, W.C. \& Haan, D. de (2000). The effects of acoustic alarms on the behavior of the harbor porpoises (phocoena phocoena) in a floating pen, Marine Mammal Science 16, 46-64. DOI: 10.1111/j.1748- 7692.2000.tb00903.x

Kastelein, R.A., de Haan, D., Vaughan, N., Staal, C. \& Schooneman, N.M. (2001). The influence of three acoustic alarms on the behaviour of harbour porpoises (Phocoena phocoena) in a floating pen, Marine Environmental Research 52, 351-371. DOI: 10.1016/S0141-1136(01)00090-3.

Kastelein, R.A., Haan, D. de, Staal, C. \& Goodson, A.D. (1997). The response of a harbour porpoise (Phocoena phocoena) to nets of various mesh sizes, with and without deterring sound, In: The biology of the harbour porpoise (Eds. Read, A.J., Wiepkema, P.R. and Nachtigall, P.E.). De Spil Publishers, Woerden, The Netherlands, 385-409.

Kastelein, R.A., Helder-Hoek, L., Van de Voorde, S., de Winter, S., Janssen, S., \& M. Ainslie (2018). Behavioral responses of harbor porpoises (Phocoena phocoena) to sonar playback sequences of sweeps and tones (3.5-4.1 kHz). Aquatic Mammals 44(4), 402-417. DOI 10.1578/AM.44.4.2018.389. 
Kastelein, R.A., Horvers, M, Helder-Hoek, L., Van de Voorde, S., ter Hofstede, R. \& van der Meij, H. (2017). Behavioral Responses of Harbor Seals (Phoca vitulina) to FaunaGuard Seal Module Sounds at Two Background Noise Levels. Aquatic Mammals 43, 347-363, DOI 10.1578/AM.43.4.2017.347.

Kastelein, R.A., Van de Voorde, S. \& N. Jennings (2018). Swimming speed of a harbor porpoise (Phocoena phocoena) during playbacks of pile driving sounds. Aquatic Mammals, 44, 92-99, DOI 10.1578/AM.44.1.2018.92

Kastelein, R.A., van der Heul, S. Terhune, J. M., Verboom W.C. \& Triesscheijn, R.J.V. (2006b). Deterring effects of 8-45 kHz tone pulses on harbor seals (Phoca vitulina) in a large pool," Marine Environmental Research 62, 356-373.

Kastelein, R.A., Verboom, W.C., Muijsers, M., Jennings, N.V., \& van der Heul, S. (2005). The influence of acoustic emissions for underwater data transmission on the behaviour of harbour porpoises (Phocoena phocoena) in a floating pen, Marine Environmental Research 59, 287-307. doi:10.1016/j.marenvres.2004.05.005.

Kastelein, R.A., Wensveen, P.J., Hoek, L., Verboom, W.C. \& Terhune J.M. (2009). Underwater detection of tonal signals between 0.125 and $100 \mathrm{kHz}$ by harbor seals (Phoca vitulina), J. Acoust. Soc. Am. 125, 1222-1229. DOI: 10.1121/1.3050283.

Kastelein, R.A., Zweypfenning, R.C.V.J. \& Spekreijse, H. (1990). Anatomical and histological characteristics of the eyes of a month-old and adult Harbor porpoise (Phocoena phocoena), In: Sensory abilities of cetaceans/Laboratory and field evidence (Eds. J.A. Thomas and R.A. Kastelein) Plenum Press, New York,463-480.

Kleijberg, R., M.J.C. Rozemeijer \& J.T. van der Wal (2019). Zandwinning Noordzee 2018-2027. Nadere verdieping effecten Natura 2000 - Actualisatie 2019. Arcadis rapport.

Krijgsveld K.L., Smits R.R. \& van der Winden J. (2008). Verstoringsgevoeligheid van vogels. Update literatuurstudie naar de reacties van vogels op recreatie. Bureau Waardenburg/Vogelbescherming Nederland rapport nr. 08-173.

Krol, J. (2010). Aantallen strandbroeders in de Nederlandse Waddenzee. Rapportage t/m broedseizoen 2008. Natuurcentrum Ameland.

Lagerveld, S., van der Wal, J. T., Vries, V., Verdaat, H., Sonneveld, C., van der Meer, J., Brabant, R. \& Noort, B. (2019). Bats at the southern North Sea in 2017 \& 2018. Den Helder: Wageningen Marine Research. 36 p. (Wageningen Marine Research report ; C062/19)

Langhamer, O. (2010). Effects of wave energy converters on the surrounding soft-bottom macrofauna (west coast of Sweden). Marine Environmental Research. Volume 69, Issue 5, June 2010, Pages 374381.

Lees, K.J., A.J. Guerin \& E.A. Masden (2016). Using kernel density estimation to marine renewable wave energy test facility. Marine Policy 63 (2016) 35-44.

Leopold M.F, Verdaat H., Spierenburg P. \& van Dijk J. 2010. Zee-eendenvoedsel op een recente zandsuppletie bij Noordwijk. IMARES Rapport C021/10.

Leopold, M. \& Scholl, M. (eds.) (2018). Monitoring getijdenturbines Oosterscheldekering.

Jaarrapportage 2017. Wageningen Marine Research, Wageningen UR (University \& Research centre), Wageningen Marine Research rapport C036/18, $49 \mathrm{blz}$

Leopold, M. \& Scholl, M. (eds.) (2019). Monitoring getijdenturbines Oosterscheldekering. Jaarrapportage 2018. Wageningen Marine Research, Wageningen UR (University \& Research centre), Wageningen Marine Research rapport C010/19, 58 blz + bijlage.

Leopold, M., M. van Asch, E. Dijkman, K. Goudswaard, S. Lagerveld, H. Verdaat, K. Camphuysen \& J. ten Horn (2014). Zwarte zee-eenden bij Texel, een reactie op overvloedig voorkomen van Ensis? IMARES Wageningen UR, Rapport C084/14.

Leopold, M., R. van Bemmelen, J. Perdon, M. Poot, C. Heunks, D. Beuker, R. Jonkvorst \& J. de Jong (2013). Zwarte Zee-eenden in de Noordzeekustzone benoorden de Wadden: verspreiding en aantallen in relatie tot voedsel en verstoring. IMARES Wageningen UR, Rapport C023/13. 
Leopold, M.F., M. Boonman, M.P. Collier, N. Davaasuren, R.C. Fijn, A. Gyimesi, J. de Jong, R.H. Jongbloed, B. Jonge Poerink, J.C. Kleyheeg-Hartman, K.L. Krijgsveld, S. Lagerveld, R. Lensink, M.J.M. Poot, J.T. van der Wal \& M. Scholl (2014). A first approach to deal with cumulative effects on birds and bats of offshore wind farms and other human activities in the Southern North Sea. IMARES report C166/14.

Love, M. S., Nishimoto, M. M., Clark, S., McCrea, M. \& Bull, A. S. (2017a). The organisms living around energized submarine power cables, pipe, and natural Sea floor in the inshore waters of Southern California. Bulletin, Southern California Academy of Sciences, 116(2), 61-88.

Love, M. S., Nishimoto, M. M., Snook, L., Schroeder, D. M., \& Scarborough Bull, A. (2017b). A Comparison of Fishes and Invertebrates Living in the Vicinity of Energized and Unenergized Submarine Power Cables and Natural Sea Floor off Southern California, USA. Journal of Renewable Energy.

Ministerie van ELI (2010). Wijzigingsbesluit Natura 2000-gebied Noordzeekustzone. Directie Regionale Zaken.

Ministerie van Infrastructuur en Milieu (2016a). Natura 2000-beheerplan Noordzeekustzone. Periode 2016-2022. Ministerie van Infrastructuur en Milieu.

Ministerie van Infrastructuur en Milieu (2016b). Kaartenbijlage Natura-2000 beheerplan Noordzeekustzone.

Ministerie van LNV (2008). Aanwijzingsbesluit Natura 2000-gebied Duinen en Lage Tand Texel. Directie Regionale Zaken DRZO/2008-002.

Møhl, B. \& Andersen, S. (1973). Echolocation: high-frequency component in the click of the Harbour Porpoise (Phocoena ph. L.), J. of Acoust. Soc. Am. 53, 1368-1372.

Nall, C.R., M-L. Schläppy \& A.J. Guerin (2017). Characterisation of the biofouling community on a floating wave energy device. Biofouling, 33:5, 379-396, DOI: 10.1080/08927014.2017.1317755.

O'Brien, N., Nash, S. \& Hartnett, M. (2015). Modelling the hydro-environmental impacts of tidal farms with the use of a two-way nested model Renewable Energies Offshore - 1st International Conference on Renewable Energies Offshore, RENEW 2014. doi.org/

Pondera Consult (2018). Passende Beoordeling Transformatiesysteem Op Zee Hollandse Kust Zuid. Rapport. Datum 17 mei 2018.

Probert, P.K. \& R. Mitchell (1983). Environmental implications of wave energy. Proposals for the Outer Hebrides and Moray Firth. Ocean Engng, Vol. 10, No 6, pp.459-469, 1983.

Reijnders, P.J.H., 1985. Verdrinking van zeehonden in fuiken. RIN-rapport 85/19. Rijksinstituut voor Natuurbeheer, Texel. 10 pp.

Reijnders, P.J.H., S.M.J.M. Brasseur, P.W. van Leeuwen \& C.J. Smit, 2005. Onderzoek naar vermindering van bijvangst van zeehonden in fuiken; risicoanalyse voor de Oosterschelde en algemene maatregelen in Nederlandse Kustwateren. Wageningen, Alterra, Alterra-rapport 1211. 30 blz.; 7 fig.; 2 tab.; 7ref.

Ries E.H., Hiby L.R., Reijnders P.J.H. (1998). Maximum likelihood population size estimation of harbour seals in the Dutch Wadden Sea based on a markrecapture experiment. Journal of Applied Ecology 35: 332-339.

Rijksdienst voor Ondernemend Nederland (2016). Natura 2000-beheerplan Texel (2). Juni 2016. Definitief beheerplan.

Snoek et al. (2016). Potential effects of electromagnetic fields in the Dutch North Sea. Phase 1 - Desk Study.

https://www.noordzeeloket.nl/publish/pages/144171/potential_effects_of_electromagnetic_fields_in_t he_dutch_north_sea_-_phase_1_desk_study_rws_wvl.pdf

Snoek et al. (2020). Potential effects of electromagnetic fields in the Dutch North Sea Phase 2 - Pilot field study.

https://www.noordzeeloket.nl/publish/pages/173407/potential_effects_of_electromagnetic_fields_in_t he_dutch_north_sea_-_phase_12pilot_study_rws_wvl.pdf 
SOVON (2007). Watervogels i Nederland in 2005/2006. Waterdienst-rapport BM07.09, SOVONmonitoringrapport 2007/03.

SOVON en CBS (2005). Trend in vogels in het Nederlandse Natura 2000 netwerk, SOVONinformatierapport 2005/09, SOVON Vogelonderzoek Nederland, Beek-Ubbergen.

SOVON Vogelonderzoek Nederland (2018). Vogelatlas van Nederland. Broedvogels, wintervogels en 40 jaar verandering. Kosmos Uitgevers, Utrecht/Antwerpen; 640 p..

Tomey-Bozo, N., A. Babarit, J. Murphy, V. Stratigaki, P. Troch, T. Lewis \& G. Thomas (2019). Wake effect assessment of a flap type wave energy converter farm under realistic environmental conditions by using a numerical coupling methodology. Coastal Engineering 143 (2019) 96-112.

Tougaard, J. (2015). Underwater Noise from a Wave Energy Converter Is Unlikely to Affect Marine Mammals. PLoS ONE 10(7): e0132391. doi:10.1371/ journal.pone.0132391

Troost, K., M. van Asch, E. Brummelhuis, D. van den Ende, Y. van Es, K.J. Perdon, J. van der Pool, C. van Zweeden en J. van Zwol. 2021. Schelpdierbestanden in de Nederlandse kustzone, Waddenzee en zoute deltawateren in 2020. CVO rapport: 21.001.

Van der Meer, P., B. Spaans en V. Stork. 2020. Vogels op Texel - Jaaroverzicht 2019. Texel.

van der Wal, J.T., M.E.B. van Puijenbroek \& M.F. Leopold (2018). Cumulatieve effecten van offshore wind parken: habitatverlies zeevogels. Update voor vijf zeevogelsoorten, met vooruitblik tot 2030. Wageningen Marine Research, Wageningen. Wageningen Marine Research rapport C059/18.

Van Hal, R., et al. (2012). Monitoring- and Evaluation Program Near Shore Wind farm (MEP- NSW): Fish community. IMARES: IJmuiden. p. 161.

Van Keeken, O.A., H.J.L. Heessen \& H.V. Winter (2010). Bescherming zoutwatervissen, Rapport C170/10.

Vogels op Texel, jaaroverzicht 2019 (2020). Vogelwerkgroep Texel.

Wiersma, P. \& C.J. Smit (2009). Hoogwatervluchtplaatsen van Texel op de kaart. SOVON onderzoeksrapport', SOVON Vogelonderzoek Nederland, Beek Ubbergen.

Winter, H.V., Aarts, G. \& van Keeken, O.A. (2010). Residence time and behaviour of sole and cod in the Offshore Wind farm Egmond aan Zee (OWEZ). IMARES Report C038/10, NoordzeeWind report number OWEZ_R_265_T1_20100916.

Witbaard, R. (2020). Biodiversiteit en abiotische metingen op de Slow Mill locatie off-shore Texel in 2019. NIOZ Report 2020-06. NIOZ Koninklijk Nederlands Instituut voor Onderzoek der Zee: Texel. 36 pp. https://doi.org/10.25850/nioz/7b.b.db

Witt, M.J., E. V. Sheehan, S. Bearhop, A. C. Broderick, D. C. Conley, S. P. Cotterell, E. Crow, W. J. Grecian, C. Halsband, D. J. Hodgson, P. Hosegood, R. Inger, P. I. Miller, D. W. Sims, R. C. Thompson, K. Vanstaen, S. C. Votier, M. J. Attrill \& B. J. Godley (2012). Assessing wave energy effects on biodiversity: the Wave Hub experience Author(s): Source: Philosophical Transactions: Mathematical, Physical and Engineering Sciences, Vol. 370, No. 1959, The Peaks and troughs of wave energy: the dreams and the reality (28 January 2012), pp. 502-529.

Woodruff et al. (2013). Effects of Electromagnetic Fields on Fish and Invertebrates Task 2.1.3: Effects on Aquatic Organisms Fiscal Year 2012 Progress Report. Environmental Effects of Marine and Hydrokinetic Energy. https://www.pnnl.gov/main/publications/external/technical_reports/PNNL22154.pdf

Wyman, M. T., Klimley, A. P., Battleson, R. D., Agosta, T. V., Chapman, E. D., Haverkamp, P. J. \& Kavet, R. (2018). Behavioral responses by migrating juvenile salmonids to a subsea high-voltage DC power cable. Marine Biology, 165(8), 134. 


\section{Verantwoording}

Rapport C061/21

Projectnummer: 4315100142

Dit rapport is met grote zorgvuldigheid tot stand gekomen. De wetenschappelijke kwaliteit is intern getoetst door een collega-onderzoeker en het verantwoordelijk lid van het managementteam van Wageningen Marine Research

Akkoord:

Drs. M.F. Leopold

Collega-onderzoeker

Handtekening:

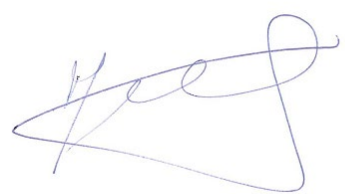

Datum:

30 juni 2021

Akkoord:

Drs. J. Asjes

Manager Integratie

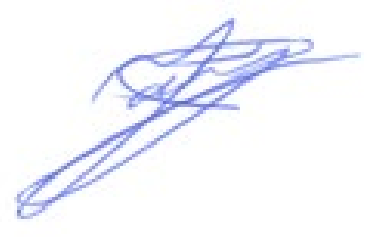

Datum:

30 juni 2021 


\section{Bijlage 1 Instandhoudingsdoelstellingen Natura 2000-gebied Noordzee- kustzone}

Instandhoudingsdoelstellingen van Natura 2000-gebied Noordzeekustzone. Aanwijzingsbesluit februari 2009 (Min. LNV, 2009)

\begin{tabular}{|c|c|c|c|c|}
\hline Instandhoudingsdoelstelling & 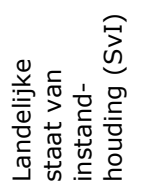 & 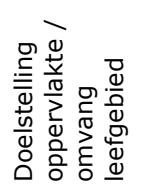 & 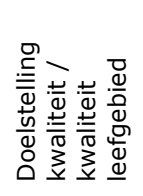 & 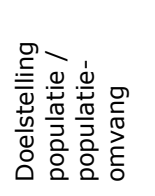 \\
\hline H1110B - Permanent overstroomde zandbanken & - & $=$ & $>$ & \\
\hline H1140B - Slik- en zandplaten & + & $=$ & $=$ & \\
\hline H1310A - Zilte pionierbegroeiingen (zeekraal) & - & $=$ & $=$ & \\
\hline H1310B - Zilte pionierbegroeiingen (zeevetmuur) & + & $=$ & $=$ & \\
\hline H1330A - Schorren en zilte graslanden (buitendijks) & - & $=$ & $=$ & \\
\hline H2110 - Embryonale duinen & + & $=$ & $=$ & \\
\hline H2190B - Vochtige duinvalleien (kalkrijk) & - & $=$ & $=$ & \\
\hline H1095 - Zeeprik & - & $=$ & $=$ & $>$ \\
\hline H1099 - Rivierprik & - & $=$ & $=$ & $>$ \\
\hline H1103 - Fint & -- & $=$ & $=$ & $>$ \\
\hline H1351 - Bruinvis & - & $=$ & $>$ & $=$ \\
\hline H1364 - Grijze zeehond & - & $=$ & $=$ & $=$ \\
\hline H1365 - Gewone zeehond & + & $=$ & $=$ & $=$ \\
\hline A137 - Bontbekplevier & - & $=$ & $=$ & 20 \\
\hline A138 - Strandplevier & -- & $>$ & $>$ & 30 \\
\hline A195 - Dwergstern & -- & $>$ & $>$ & 20 \\
\hline A001 - Roodkeelduiker & - & $=$ & $=$ & \\
\hline A002 - Parelduiker & $?$ & $=$ & $=$ & \\
\hline A017 - Aalscholver & + & $=$ & $=$ & $1900^{*}$ \\
\hline A048 - Bergeend & + & $=$ & $=$ & $520 *$ \\
\hline A062 - Topper & -- & $=$ & $=$ & \\
\hline A063 - Eider & -- & $=$ & $=$ & $26200^{* *}$ \\
\hline A065 - Zwarte zee-eend & - & $=$ & $=$ & $51900 * *$ \\
\hline A130 - Scholekster & -- & $=$ & $=$ & $3300 *$ \\
\hline A132 - Kluut & - & $=$ & $=$ & $120 *$ \\
\hline A137 - Bontbekplevier & + & $=$ & $=$ & $510^{*}$ \\
\hline A141 - Zilverplevier & + & $=$ & $=$ & $3200 *$ \\
\hline A143 - Kanoet & - & $=$ & $=$ & $560 *$ \\
\hline A144 - Drieteenstrandloper & - & $=$ & $=$ & 2000 \\
\hline A149 - Bonte strandloper & + & $=$ & $=$ & $7400 *$ \\
\hline A157 - Rosse grutto & + & $=$ & $=$ & $1800 *$ \\
\hline A160 - Wulp & + & $=$ & $=$ & $640 *$ \\
\hline A169 - Steenloper & -- & $=$ & $=$ & 160 \\
\hline A177 - Dwergmeeuw & - & $=$ & $=$ & \\
\hline
\end{tabular}

\begin{tabular}{|l|l|l|l|l|l|}
\hline \multicolumn{2}{|l|}{ Legenda: } & \multicolumn{2}{l|}{ Doelstelling } & \multicolumn{2}{l|}{ Populatieomvang } \\
\hline \multicolumn{2}{|l|}{ Staat van instandhouding } & $=$ & behoud & $*$ & seizoensmaximum \\
\hline+ & gunstig & $>$ & Uitbreiding & $* *$ & $*$ midwinter aantallen \\
\hline- & matig gunstig & & & & \\
\hline-- & zeer ongunstig & & & & \\
\hline
\end{tabular}




\section{Bijlage 2 Instandhoudingsdoelstellingen Natura 2000-gebied Duinen en Lage Land Texel}

Instandhoudingsdoelstellingen van Natura 2000-gebied Duinen en Lage Land Texel. Aanwijzingsbesluit februari 2009 (Ministerie van LNV, 2008).

\begin{tabular}{|c|c|c|c|c|}
\hline Instandhoudingsdoelstelling & 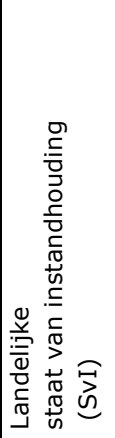 & 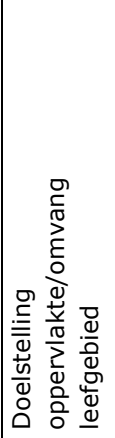 & 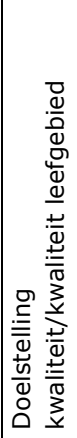 & 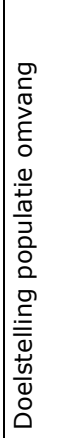 \\
\hline H1140A - Slik- en zandplaten (getijdengebied) & - & $=$ & $=$ & \\
\hline H1330A - Schorren en zilte graslanden (buitendijks) & - & $=$ & $=$ & \\
\hline H1330B - Schorren en zilte graslanden (binnendijks) & - & $=$ & $=$ & \\
\hline H2110 - Embryonale duinen & + & $=$ & $=$ & \\
\hline H2120 - Witte duinen & - & $=$ & $=$ & \\
\hline H2130A - *Grijze duinen (kalkrijk) & -- & $>$ & $>$ & \\
\hline H2130B - *Grijze duinen (kalkarm) & -- & $>$ & $>$ & \\
\hline H2130C - *Grijze duinen (heischraal) & -- & $>$ & $>$ & \\
\hline H2180B - Duinbossen (vochtig) & - & $=(<)$ & $>$ & \\
\hline H2180C - Duinbossen (binnenduinrand) & - & $=$ & $>$ & \\
\hline H2190A - Vochtige duinvalleien (open water) & - & $=$ & $>$ & \\
\hline H2190B - Vochtige duinvalleien (kalkrijk) & - & $=$ & $>$ & \\
\hline H2190C - Vochtige duinvalleien (ontkalkt) & - & $=$ & $>$ & \\
\hline H2190D - Vochtige duinvalleien (hoge moerasplanten) & - & $=$ & $>$ & \\
\hline H6230 - *Heischrale graslanden & -- & $=$ & $=$ & \\
\hline \multicolumn{5}{|l|}{ H6410 } \\
\hline H6430A - Ruigten en zomen (moerasspirea) & + & $=$ & $=$ & \\
\hline H6430B - Ruigten en zomen (harig wilgenroosje) & - & $=$ & $=$ & \\
\hline H6430C - Ruigten en zomen (droge bosranden) & - & $=$ & $=$ & \\
\hline H7210 - *Galigaanmoerassen & - & $=$ & $=$ & \\
\hline H1340 - *Noordse woelmuis & -- & $=$ & $>$ & $=$ \\
\hline H1364 - Grijze zeehond & - & $=$ & $=$ & $=$ \\
\hline H1903 - Groenknolorchis & -- & $=$ & $=$ & $=$ \\
\hline
\end{tabular}




\begin{tabular}{|c|c|c|c|c|}
\hline Instandhoudingsdoelstelling & 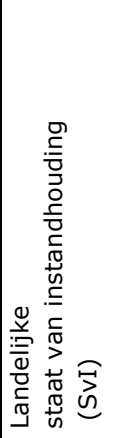 & 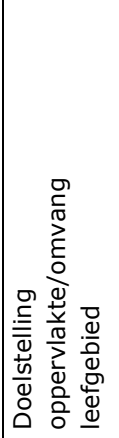 & 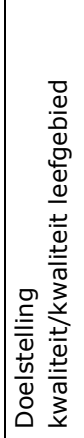 & 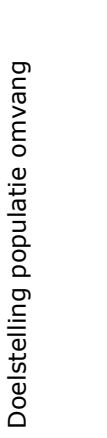 \\
\hline A034 - Lepelaar & + & $=$ & $=$ & 120 \\
\hline A063 - Eider & -- & $=$ & $=$ & 110 \\
\hline A081 - Bruine kiekendief & + & $=$ & $=$ & 30 \\
\hline A082 - Blauwe kiekendief & -- & $=$ & $=$ & 20 \\
\hline A132 - Kluut & - & $=$ & $=$ & 120 \\
\hline A137 - Bontbekplevier & - & $>$ & $>$ & 20 \\
\hline \multicolumn{5}{|l|}{ A138 - Strandplevier } \\
\hline A183 - Kleine mantelmeeuw & + & $=$ & $=$ & 14000 \\
\hline A195 - Dwergstern & -- & $>$ & $>$ & 40 \\
\hline A222 - Velduil & -- & $>$ & $>$ & 20 \\
\hline A276 - Roodborsttapuit & + & $=$ & $=$ & 40 \\
\hline A277 - Tapuit & -- & $>$ & $>$ & 100 \\
\hline
\end{tabular}

Legenda: zie legenda bij abel in Bijlage 1 


\section{Bijlage 3 Kaart met habitattypen van Natura 2000-gebieden Texel}

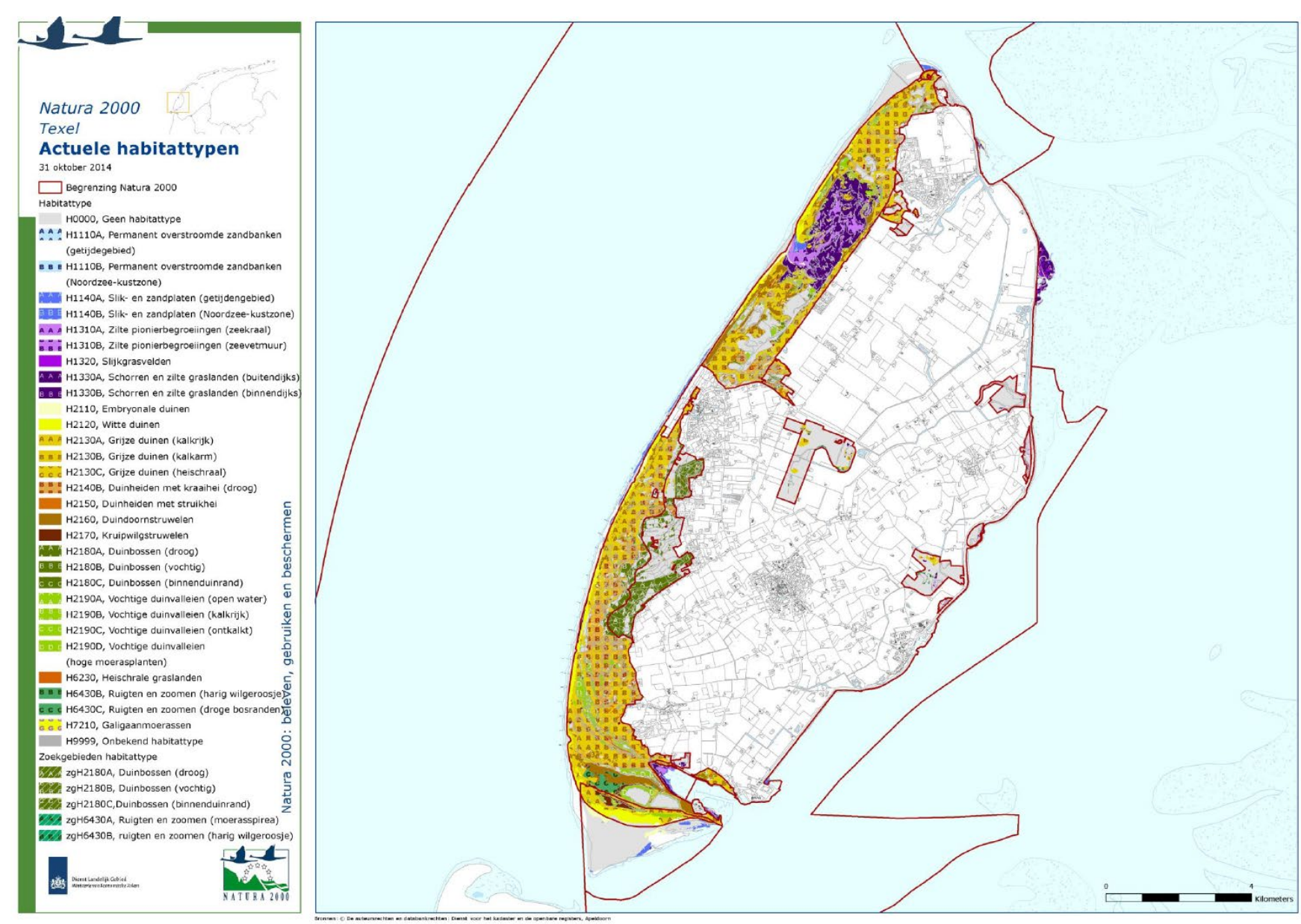

Figuur 15 Habitattypen Natura 2000-gebieden op en rondom Texel (Rijksdienst voor Ondernemend Nederland 2016. Natura 2000-beheerplan Texel (2). Juni 2016. Definitief beheerplan) 
Bijlage 4 Lijst van soorten die op bijlage IV van de habitatrichtlijn, bijlage II van Bern en/of bijlage I van Bonn staan 
Lijst van soorten die op bijlage IV van de habitatrichtlijn, bijlage II van Bern en/of bijlage I van Bonn staan.

\section{Planten (4)}

Groenknolorchis

Drijvende waterweegbree

Kruipend moerasscherm

Zomerschroeforchis

Amfibieën en reptielen (11)

\begin{tabular}{l} 
Boomkikker \\
Geelbuikvuurpad \\
Gladde slang \\
Heikikker \\
Kamsalamander \\
Knoflookpad \\
\hline Muurhagedis \\
Poelkikker \\
Rugstreeppad \\
Vroedmeesterpad \\
Zandhagedis
\end{tabular}

Slakken en vissen (3)

Houting

Platte schijfhoren

Steur

\section{Dagvlinders (10) \\ Apollovlinder \\ Boszandoog \\ Donker pimpernelblauwtje \\ gentiaanblauwtje \\ Grote vuurvlinder \\ Moerasparelmoervlinder \\ Pimpernelblauwtje \\ Teunisbloempijlstaart \\ Tijmblauwtje \\ Zilverstreephooibeestje}

plant
plant
plant
plant

amfibie

amfibie

reptiel

amfibie

amfibie

amfibie

reptiel

amfibie

amfibie

amfibie

reptiel

vis

slak

vis

dagvlinder

dagvlinder

dagvlinder

dagvlinder

dagvlinder

dagvlinder

dagvlinder

dagvlinder

dagvlinder

dagvlinder
HR bijl. IV \& Bern bijl. I

HR bijl. IV \& Bern bijl. I

HR bijl. IV \& Bern bijl. I

HR bijl. IV \& Bern bijl. I
HR bijl. IV \& Bern bijl. II HR bijl. IV \& Bern bijl. II HR bijl. IV \& Bern bijl. II HR bijl. IV \& Bern bijl. II HR bijl. IV \& Bern bijl. II HR bijl. IV \& Bern bijl. II HR bijl. IV \& Bern bijl. II HR bijl. IV

HR bijl. IV \& Bern bijl. II HR bijl. IV \& Bern bijl. II HR bijl. IV \& Bern bijl. II

HR bijl. IV

HR bijl. IV

HR bijl. IV \& Bern bijl. II

\section{Zoogdieren (27)}

Baardvleermuis

Bechsteins vleermuis

Bever

Bosvleermuis

Brandts vleermuis

Franjestaart

Gewone dwergvleermuis

Gewone grootoorvleermuis

Grijze grootoorvleermuis

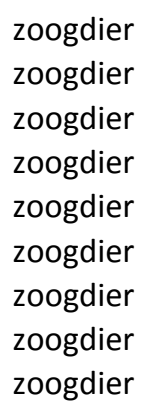

\author{
HR bijl. IV \& Bern bijl. II \\ HR bijl. IV \& Bern bijl. II \\ HR bijl. IV \& Bern bijl. II \& art. 3.10 lid 1 a \\ Bern bijl. II \& art. 3.10 lid 1 a \\ HR bijl. IV \& Bern bijl. II \& art. 3.10 lid 1 a \\ Bern bijl. II \\ Bern bijl. II \& art. 3.10 lid 1 a \\ HR bijl. IV \& Bern bijl. II \\ HR bijl. IV \& Bern bijl. II \\ HR bijl. IV \& Bern bijl. II
}

HR bijl. IV \& Bern bijl. II HR bijl. IV \& Bern bijl. II

HR bijl. IV

HR bijl. IV \& Bern bijl. II

Bern bijl. II

HR bijl. IV \& Bern bijl. II

HR bijl. IV

HR bijl. IV \& Bern bijl. II

HR bijl. IV \& Bern bijl. II 


Grote hoefijzerneus
Grote rosse vleermuis
Hamster
Hazelmuis
Ingekorven vleermuis
Kleine hoefijzerneus
Laatvlieger
Lynx (euraziatische)
Meervleermuis
Mopsvleermuis
Noordse vleermuis
Noordse woelmuis
Otter
Rosse vleermuis
Ruige dwergvleermuis
(Nathusius dwergvleermuis)
Tweekleurige vleermuis
Vale vleermuis
Watervleermuis
Wolf

zoogdier zoogdier zoogdier zoogdier zoogdier zoogdier zoogdier zoogdier zoogdier zoogdier zoogdier zoogdier zoogdier zoogdier

zoogdier zoogdier zoogdier zoogdier zoogdier

Kevers, libellen en haft (14) Brede geelrandwaterroofkever Bronslibel

Gaffellibel

Gestreepte waterroofkever

Gevlekte witsnuitlibel

Groene glazenmaker

Mercuurwaterjuffer

Juchtleerkever

Noordse winterjuffer

Oostelijke witsnuitlibel

Rivierrombout

Sierlijke witsnuitlibel

Vermiljoenkever

Oeveraas (Palingenia longicauda) kever

libel

libel

kever

libel

libel libel

kever

libel

libel

libel

libel

kever

haft

\section{Weekdieren en zeezoogdieren (27)}

Bataafse stroommossel
Bruinvis
Bultrug
Butskop
Dikkopschildpad
Dwergpotvis
Dwergvinvis
Gestreepte dolfijn
Gewone dolfijn
Gewone spitsdolfijn
Gewone vinvis
Griend

weekdier zeedier zeedier zeedier zeedier zeedier zeedier zeedier zeedier zeedier zeedier zeedier

HR bijl. IV \& Bern bijl. II

Bern bijl. II

HR bijl. IV \& Bern bijl. II

HR bijl. IV

HR bijl. IV \& Bern bijl. II HR bijl. IV \& Bern bijl. II HR bijl. IV \& Bern bijl. II HR bijl. IV

HR bijl. IV \& Bern bijl. II HR bijl. IV \& Bern bijl. II HR bijl. IV \& Bern bijl. II HR bijl. IV

HR bijl. IV \& Bern bijl. II HR bijl. IV \& Bern bijl. II

HR bijl. IV \& Bern bijl. II HR bijl. IV \& Bern bijl. II HR bijl. IV \& Bern bijl. II HR bijl. IV \& Bern bijl. II HR bijl. IV \& Bern bijl. II

HR bijl. IV \& Bern bijl. II HR bijl. IV \& Bern bijl. II HR bijl. IV \& Bern bijl. II HR bijl. IV \& Bern bijl. II HR bijl. IV \& Bern bijl. II

HR bijl. IV \& Bern bijl. II Bern bijl. II HR bijl. IV \& Bern bijl. II HR bijl. IV \& Bern bijl. II HR bijl. IV \& Bern bijl. II HR bijl. IV \& Bern bijl. II HR bijl. IV \& Bern bijl. II HR bijl. IV \& Bern bijl. II

Bern bijl. II

HR bijl. IV

Bern bijl. II

Bern bijl. II \& Bonn bijl. I

HR bijl. IV

HR bijl. IV \& Bern bijl. II \& Bonn bijl. I

Bern bijl. II

HR bijl. IV

Bern bijl. II

Bern bijl. II

Bern bijl. II

HR bijl. IV \& Bern bijl. II \& Bonn bijl. I

HR bijl. IV \& Bern bijl. II 


Grijze dolfijn
Kemp's zeeschildpad
Kleine zwaardwalvis
Lederschildpad
Narwal
Noordse vinvis
Orca
Potvis
Soepschildpad
Spitsdolfijn van Gray
Tuimelaar
Walrus
Witflankdolfijn
Witsnuitdolfijn
Witte dolfijn

zeedier
zeedier
zeedier
zeedier
zeedier
zeedier
zeedier
zeedier
zeedier
zeedier
zeedier
zeedier
zeedier
zeedier
zeedier
Bern bijl. II

HR bijl. IV \& Bern bijl. II \& Bonn bijl. I

Bern bijl. II

HR bijl. IV \& Bern bijl. II \& Bonn bijl. I

HR bijl. IV \& Bern bijl. II

HR bijl. IV \& Bonn bijl. I

HR bijl. IV \& Bern bijl. II

HR bijl. IV \& Bonn bijl. I

HR bijl. IV \& Bern bijl. II \& Bonn bijl. I

HR bijl. IV

HR bijl. IV \& Bern bijl. II

Bern bijl. II

HR bijl. IV \& Bern bijl. II

HR bijl. IV \& Bern bijl. II

HR bijl. IV 


\section{Bijlage 5 Lijst van waargenomen mariene soorten die op bijlage II, III en IV van de habitatrichtlijn staan}

Overzicht van soorten die genoemd zijn in bijlage II, IV en/of V van de Habitatrichtlijn en die na 1900 in het wild in Nederland zijn waargenomen

(http://minez.nederlandsesoorten. $\mathrm{nl} /$ content/habitatrichtlijn). Met uitzondering van een aantal vleermuissoorten* zijn alleen de mariene soorten hier weergegeven, inclusief het voorkomen in de Nederlandse Noordzee (de status volgens het Nederlands soortregister van het ministerie van EZ (nu LNV; http://minez.nederlandsesoorten.nl/soorten), uitgezonderd vleermuissoorten).

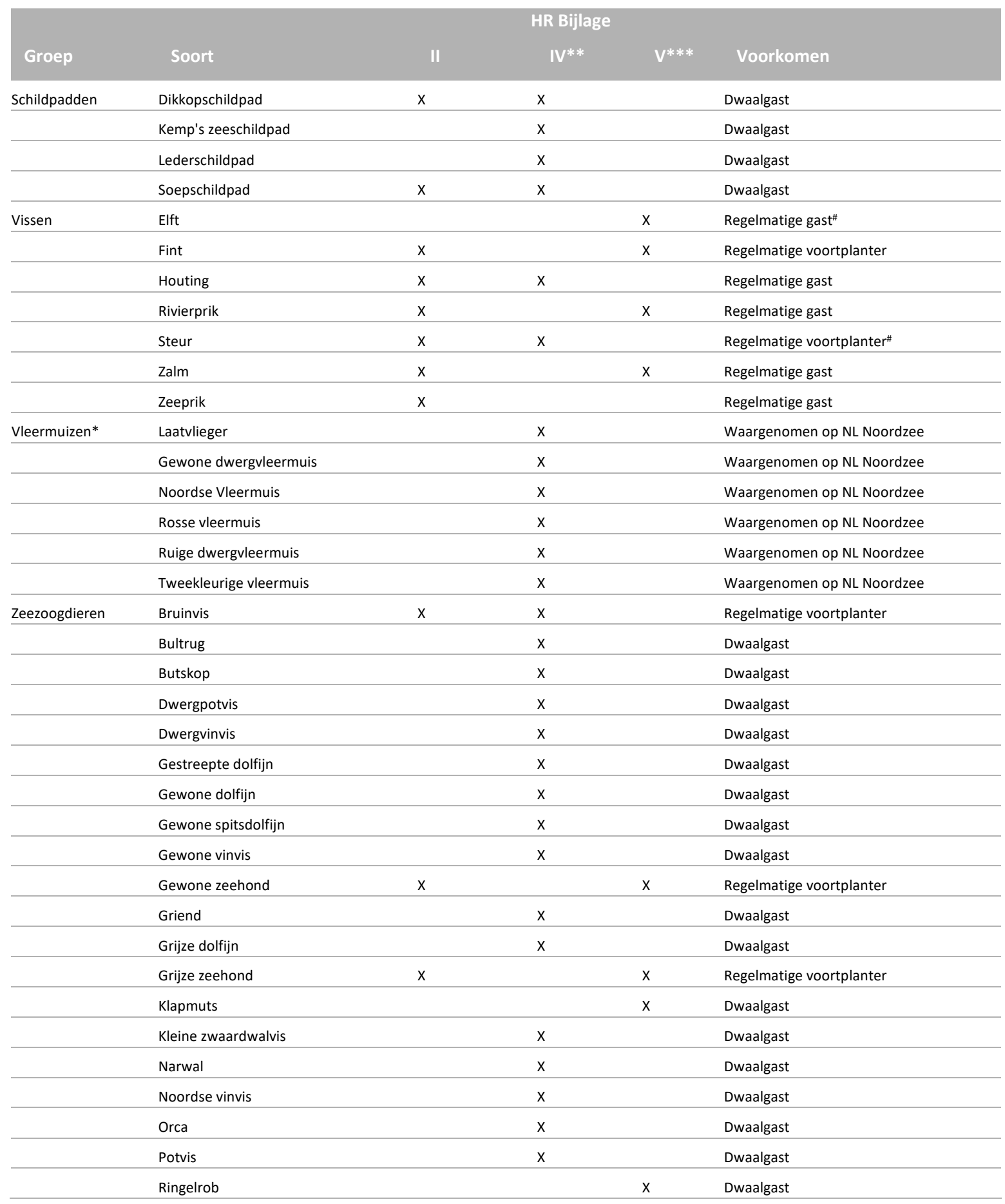




\begin{tabular}{|c|c|c|c|c|c|}
\hline \multirow[b]{2}{*}{ Groep } & \multicolumn{5}{|c|}{ HR Biflage } \\
\hline & Soort & II & IV** & $\mathbf{V}^{* * *}$ & Voorkomen \\
\hline & Spitsdolfijn van Gray & & $x$ & & Dwaalgast \\
\hline & Tuimelaar & $x$ & $x$ & & Regelmatige voortplanter ${ }^{\#}$ \\
\hline & Walrus & & $x$ & & Dwaalgast \\
\hline & Witflankdolfijn & & $x$ & & Dwaalgast \\
\hline & Witsnuitdolfijn & & $x$ & & Regelmatige voortplanter \\
\hline & Witte dolfijn & & $x$ & & Dwaalgast \\
\hline & Zadelrob & & & $x$ & Dwaalgast \\
\hline
\end{tabular}

*Voor wat betreft vleermuizen zijn alleen de soorten weergegeven die zijn waargenomen op de Nederlandse Noordzee, op basis van Leopold et al. (2014); ** incl. Bern annex II en Bonn annex I; *** incl. Bern annex III en Bonn annex II ; \#Status ter discussie

Deze bijlage is overgenomen uit Tamis, J.E., R.H. Jongbloed, A. Asjes, P. de Vries, G.J. Piet (2019): NatuurBalans Noordzee. Voorbeeld uitwerking van een Noordzee bijdrage aan de Balans van de Leefomgeving. Wageningen University \& Research rapport C034/19. 


\section{Bijlage 6 Resultaat beoordeling Voortoets Slow Mill pilot Texel}

Resultaat van de Voortoets met de globale beoordeling van de effecten die van de verschillende verstoringsfactoren als gevolg van de activiteiten voor de Slow Mill-pilotinstallatie kunnen uitgaan, op instandhoudingsdoelen van de Noordzeekustzone. Deze tabel is integraal overgenomen uit de Voortoets (Jongbloed et al. 2020).

\begin{tabular}{|c|c|c|c|c|c|c|c|c|c|c|c|c|}
\hline Instandhoudingsdoelen & 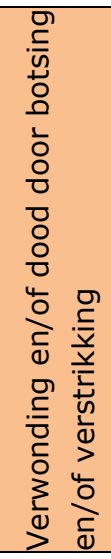 & 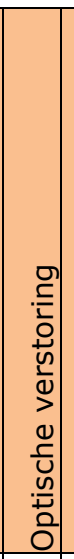 & 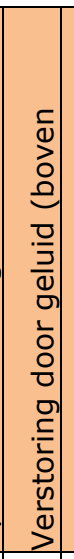 & 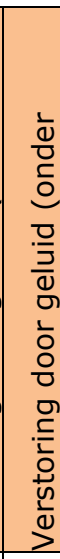 & \begin{tabular}{|c|} 
\\
\\
0 \\
$\frac{\pi}{0}$ \\
$\frac{0}{0}$ \\
0 \\
0 \\
0 \\
$\frac{c}{0}$ \\
$\frac{0}{0}$ \\
$\frac{0}{0}$ \\
0 \\
\end{tabular} & 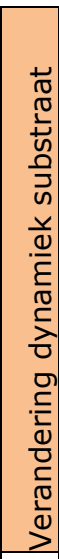 & 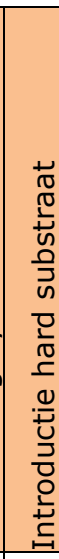 & 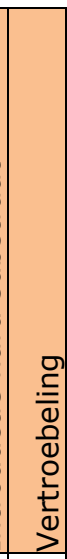 & 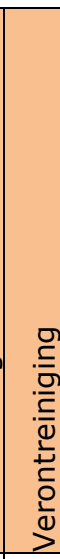 & 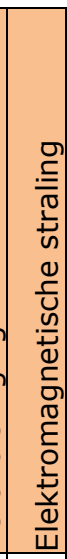 & 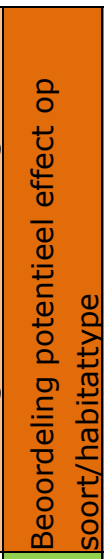 & 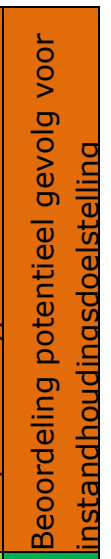 \\
\hline $\mathrm{H} 1110 \mathrm{~B}$ - Permanent overstroomde zandbanken & & & & & $\mathrm{v}$ & $\mathrm{v}$ & $x$ & $\mathrm{v}$ & $\mathrm{v}$ & & $\mathrm{v}$ & $\mathrm{U}$ \\
\hline H1140B - Slik- en zandplaten & & & & & $\mathrm{x}$ & $\mathrm{x}$ & & & & & $\mathrm{V}$ & $\mathrm{u}$ \\
\hline H1310A - Zilte pionierbegroeiingen (zeekraal) & & & & & & & & & & & G & $u$ \\
\hline H1310B - Zilte pionierbegroeiingen (zeevetmuur) & & & & & & & & & & & $\mathrm{G}$ & $\mathrm{U}$ \\
\hline $\begin{array}{l}\text { H1330A - Schorren en zilte graslanden } \\
\text { (buitendijks) }\end{array}$ & & & & & & & & & & & G & $\mathrm{u}$ \\
\hline H2110 - Embryonale duinen & & & & & & & & & & & G & $\mathrm{U}$ \\
\hline H2190B - Vochtige duinvalleien (kalkrijk) & & & & & & & & & & & G & $\mathrm{u}$ \\
\hline H1095 - Zeeprik & $x$ & & & $\mathrm{v}$ & & & $\mathrm{v}$ & & & $\mathrm{v}$ & $\mathrm{P}$ & $\mathrm{P}$ \\
\hline H1099 - Rivierprik & $x$ & & & $\mathrm{v}$ & & & $\mathrm{v}$ & & & $\mathrm{v}$ & $P$ & $P$ \\
\hline H1103 - Fint & $x$ & & & $x$ & & & $\mathrm{v}$ & & & $\mathrm{v}$ & $\mathrm{P}$ & $\mathrm{P}$ \\
\hline H1351 - Bruinvis & $x$ & $?$ & & $x$ & & & $\mathrm{v}$ & & & $\mathrm{v}$ & $P$ & $P$ \\
\hline H1364 - Grijze zeehond & $x$ & $?$ & & $x$ & & & $\mathrm{v}$ & & & $\mathrm{v}$ & $\mathrm{P}$ & $\mathrm{P}$ \\
\hline H1365 - Gewone zeehond & $x$ & $?$ & & $x$ & & & $\mathrm{v}$ & & & $\mathrm{v}$ & $\mathrm{P}$ & $P$ \\
\hline A137 - Bontbekplevier & & $x$ & $x$ & & & & & & & & $\mathrm{G}$ & $\mathrm{U}$ \\
\hline A138 - Strandplevier & & $x$ & $x$ & & & & & & & & $\mathrm{G}$ & $\mathrm{U}$ \\
\hline A195 - Dwergstern & & $x$ & $x$ & & $\mathrm{v}$ & $\mathrm{v}$ & $\mathrm{v}$ & & $\mathrm{v}$ & & G & $u$ \\
\hline A001 - Roodkeelduiker & $\mathrm{x}$ & $x$ & $x$ & & $\mathrm{v}$ & $\mathrm{v}$ & $\mathrm{v}$ & & $\mathrm{v}$ & & $\mathrm{P}$ & $\mathrm{P}$ \\
\hline A002 - Parelduiker & $x$ & $x$ & $x$ & & $\mathrm{v}$ & $\mathrm{v}$ & $\mathrm{v}$ & & $\mathrm{v}$ & & $\mathrm{P}$ & $\mathrm{P}$ \\
\hline A017 - Aalscholver & $x$ & $\mathrm{v}$ & $x$ & & $\mathrm{v}$ & $\mathrm{v}$ & $\mathrm{v}$ & & $\mathrm{v}$ & & $P$ & $P$ \\
\hline A048 - Bergeend & & $\mathrm{v}$ & $\mathrm{x}$ & & & & & & & & $\mathrm{V}$ & U \\
\hline A062 - Topper & $x$ & $x$ & $x$ & & $\mathrm{v}$ & $\mathrm{v}$ & $\mathrm{v}$ & & $\mathrm{v}$ & & $\mathrm{V}$ & $u$ \\
\hline A063 - Eider & $x$ & $x$ & $x$ & & $\mathrm{v}$ & $\mathrm{v}$ & $\mathrm{v}$ & & $\mathrm{v}$ & & $\mathrm{P}$ & $\mathrm{P}$ \\
\hline A065 - Zwarte zee-eend & $x$ & $x$ & $x$ & & $\mathrm{v}$ & $\mathrm{v}$ & $\mathrm{v}$ & & $\mathrm{v}$ & & $\mathrm{P}$ & $P$ \\
\hline A130 - Scholekster & & $x$ & $x$ & & & & & & & & $\mathrm{~V}$ & $U$ \\
\hline A132 - Kluut & & $x$ & $\mathrm{x}$ & & & & & & & & $\mathrm{V}$ & $u$ \\
\hline A137 - Bontbekplevier & & $x$ & $x$ & & & & & & & & $\mathrm{~V}$ & $U$ \\
\hline A141 - Zilverplevier & & $x$ & $x$ & & & & & & & & V & 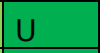 \\
\hline A143 - Kanoet & & $x$ & $x$ & & & & & & & & $\mathrm{~V}$ & $\mathrm{U}$ \\
\hline A144 - Drieteenstrandloper & & $x$ & $x$ & & & & & & & & $\mathrm{~V}$ & $\mathrm{U}$ \\
\hline A149 - Bonte strandloper & & $x$ & $x$ & & & & & & & & $\mathrm{~V}$ & $\mathrm{U}$ \\
\hline
\end{tabular}




\begin{tabular}{|l|l|l|l|l|l|l|l|l|l|l|l|l|}
\hline A157 - Rosse grutto & & x & x & & & & & & & & V & U \\
\hline A160 - Wulp & & x & x & & & & & & & & V & U \\
\hline A169 - Steenloper & & V & x & & & & & & & & V & U \\
\hline A177 - Dwergmeeuw & V & x & x & & V & v & & V & V & & P & P \\
\hline
\end{tabular}

Legenda:

\begin{tabular}{|l|l|}
\hline Weergave & Effect van verstoringsfactor \\
\hline & Geen blootstelling \\
\hline V & Verwaarloosbaar effect \\
\hline X & Potentieel effect \\
\hline$?$ & Onbekend effect \\
\hline
\end{tabular}

\begin{tabular}{|l|l|}
\hline Weergave & Effect van alle verstoringsfactoren samen \\
\hline G & Geen effect \\
\hline V & Verwaarloosbaar effect \\
\hline P & Potentieel effect \\
\hline
\end{tabular}

\begin{tabular}{|l|l|}
\hline Weergave & Effectbeoordeling instandhoudingsdoelen \\
\hline$U$ & Significante effecten worden uitgesloten \\
\hline$P$ & Significante effecten kunnen niet worden uitgesloten \\
\hline
\end{tabular}




\section{Bijlage 7 Verspreidingskaarten zeezoogdieren}

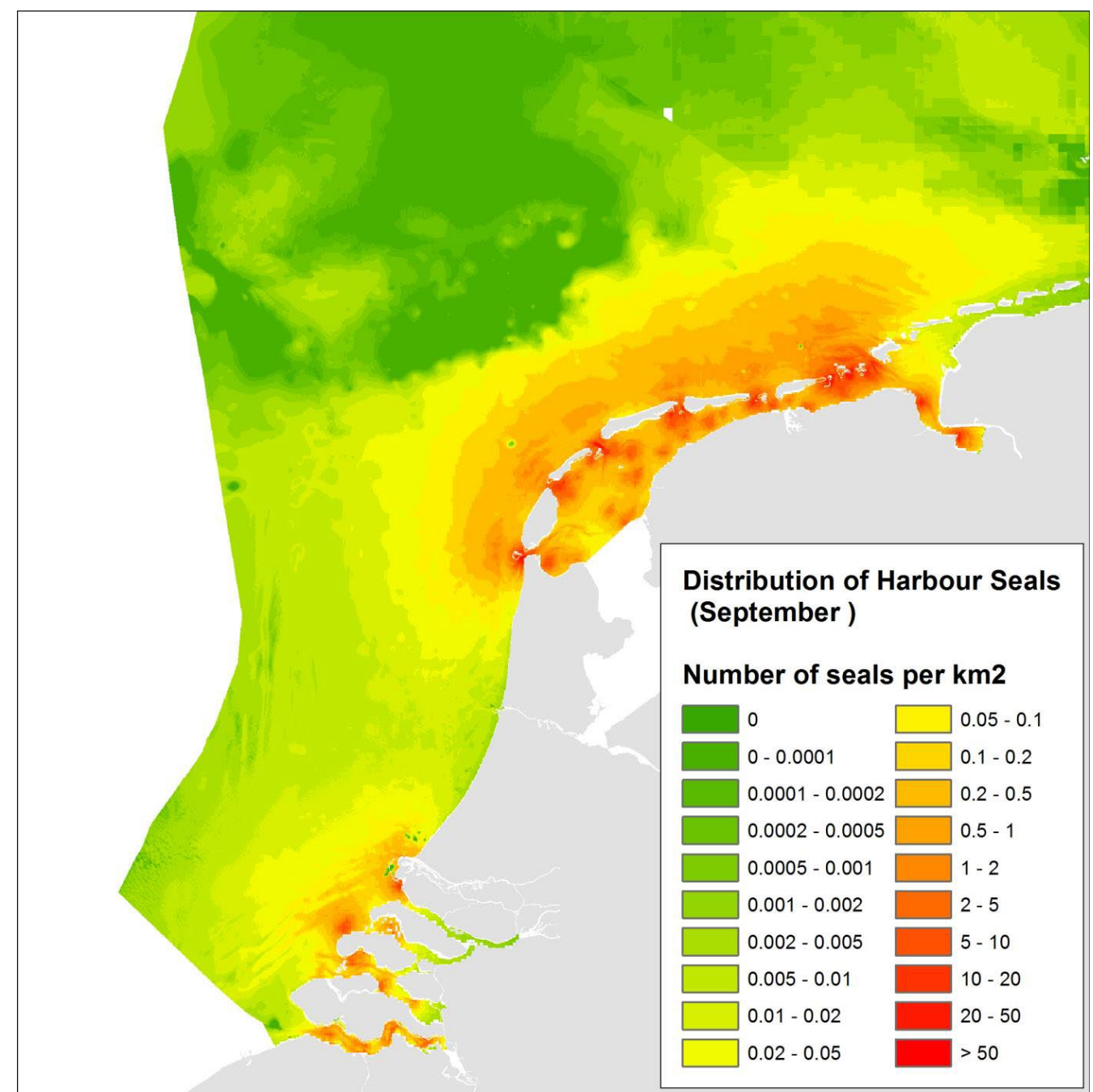

Figuur 16 Voorspelde dichtheden van de gewone zeehond (aantal individuen/km2) op het NCP in de maand september. Bron: Aarts et al. (2016) 

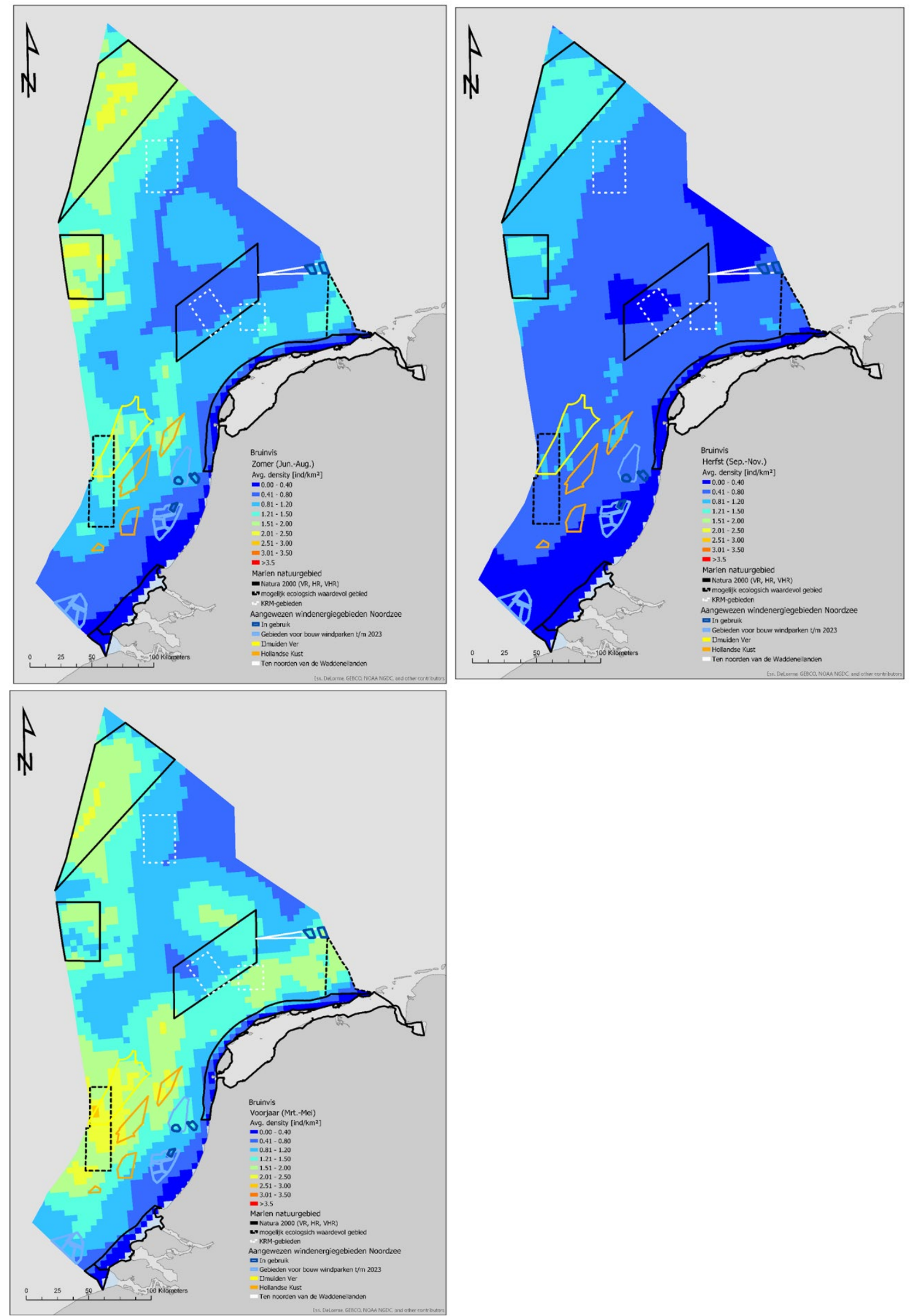

Figuur 17 Voorspelde gemiddelde dichtheden ("Avg. density", aantal individuen/km2) van de bruinvis op het NCP in de zomer (juni-augustus), de herfst (september-november) en het voorjaar (maartmei). Bron: Gilles et al. 2016). Met aanduiding van de ligging van drie typen natuurgebieden: Natura 2000, mogelijk ecologische waardevol gebied en KRM-gebieden. KRM-gebieden zijn gebieden die kandidaat zijn voor aanwijzing als beschermde gebieden onder de Kaderrichtlijn Marien. 


\section{Bijlage 8 Trends voor zeehonden}

Aantallen en trends van gewone zeehonden en grijze zeehonden in de telgebieden van de Waddenzee.

\begin{tabular}{|c|c|c|c|c|c|c|c|c|c|c|c|c|c|}
\hline \multicolumn{14}{|c|}{ Onderliggende data: } \\
\hline \multicolumn{14}{|c|}{ Aantallen gewone zeehonden per gebied in augustus } \\
\hline JAAR & 01 & 02 & 03 & 04 & 05 & 06 & 07 & 08 & 09 & 10 & 11 & 13 & SOM \\
\hline 2002 & 143 & 323 & 562 & 471 & 239 & 65 & 289 & 287 & 210 & 96 & 142 & 71 & 2898 \\
\hline 2003 & 121 & 335 & 373 & 369 & 251 & 53 & 185 & 307 & 161 & 64 & 108 & 38 & 2365 \\
\hline 2004 & 253 & 356 & 550 & 502 & 363 & 47 & 281 & 426 & 186 & 74 & 97 & 59 & 3194 \\
\hline 2005 & 224 & 426 & 589 & 558 & 304 & 53 & 430 & 315 & 267 & 84 & 127 & 66 & 3443 \\
\hline 2006 & 289 & 355 & 831 & 646 & 378 & 78 & 485 & 531 & 177 & 80 & 141 & 74 & 4065 \\
\hline 2007 & 390 & 366 & 793 & 640 & 394 & 85 & 580 & 488 & 189 & 71 & 120 & 43 & 4159 \\
\hline 2008 & 302 & 677 & 976 & 1073 & 558 & 143 & 971 & 591 & 413 & 119 & 117 & 32 & 5972 \\
\hline 2009 & 361 & 863 & 1304 & 982 & 525 & 132 & 717 & 588 & 533 & 196 & 146 & 52 & 6399 \\
\hline 2010 & 321 & $800^{*}$ & 1113 & 848 & 557 & 148 & 683 & 554 & 430 & 221 & 159 & 50 & $5884^{*}$ \\
\hline 2011 & 627 & 1138 & 1168 & 1158 & 756 & 117 & 964 & 495 & 510 & 209 & 193 & 43 & 7378 \\
\hline 2012 & 545 & 991 & 1082 & 782 & 797 & 173 & 874 & 694 & 465 & 175 & 120 & 103 & $6801^{*}$ \\
\hline 2013 & 752 & 989 & 1242 & 869 & 637 & 182 & 1124 & 788 & 564 & 220 & 169 & 69 & 7605 \\
\hline 2014 & 970 & 737 & 1230 & 761 & 811 & 142 & 880 & 561 & 489 & 209 & 237 & 59 & 7086 \\
\hline 2015 & 886 & 784 & 1079 & 1017 & 523 & 207 & 1082 & 901 & 613 & 244 & 221 & 109 & 7666 \\
\hline 2016 & 1083 & 1123 & 1322 & 798 & 448 & 207 & 1154 & 797 & 727 & 243 & 182 & 76 & 8160 \\
\hline 2017 & 1324 & 1154 & 1324 & 1118 & 586 & 156 & 1288 & 362 & 689 & 188 & 153 & 85 & $8427^{*}$ \\
\hline 2018 & 1067 & $1151^{*}$ & 1154 & 877 & 463 & 164 & 1151 & 519 & 800 & 231 & 227 & 121 & $7925^{*}$ \\
\hline 2019 & 1259 & 771 & 1251 & 766 & 387 & 149 & 1151 & 516 & 602 & 241 & 143 & 102 & 7338 \\
\hline 2020 & 1220 & 809 & 1302 & 719 & 447 & 149 & 1166 & 628 & 791 & 172 & 184 & 74 & 7661 \\
\hline
\end{tabular}

Tabel 1. Aantallen gewone zeehonden per telgebied in augustus voor de jaren 2002 tot 2020.

https://www.wur.nl/nl/show/Populatie-Gewone-Zeehonden-in-de-Nederlandse-Waddenzee.htm

\begin{tabular}{|c|c|c|c|c|c|c|c|c|c|c|c|c|c|}
\hline \multicolumn{14}{|c|}{ Onderliggende data: } \\
\hline \multicolumn{14}{|c|}{ Aantallen grijze zeehonden per gebied in maart/april } \\
\hline JAAR & 01 & 02 & 03 & 04 & 05 & 06 & 07 & 08 & 09 & 10 & 11 & 13 & som \\
\hline 2008 & 350 & 0 & 1297 & 69 & 0 & 0 & 0 & 0 & 0 & 0 & 0 & 0 & 1716 \\
\hline 2009 & 205 & 181 & 1667 & 54 & 0 & 0 & 0 & 0 & 0 & 0 & 0 & 1 & 2108 \\
\hline 2010 & 316 & 142 & 1554 & 24 & 0 & 0 & 0 & 0 & 0 & 0 & 0 & 0 & 2036 \\
\hline 2011 & 105 & 311 & 1946 & 15 & 8 & 0 & 0 & 0 & 0 & 1 & 0 & 2 & 2388 \\
\hline 2012 & 121 & 214 & 2619 & 48 & 38 & 0 & 0 & 0 & 0 & 0 & 0 & 22 & 3062 \\
\hline 2013 & 261 & 104 & 1457 & 0 & 0 & 0 & 0 & 0 & 0 & 0 & 0 & 0 & $1822^{*}$ \\
\hline 2014 & 537 & 197 & 2593 & 13 & 9 & 0 & 15 & 0 & 0 & 0 & 0 & 0 & 3364 \\
\hline 2015 & 699 & 96 & 2725 & 22 & 1 & 0 & 0 & 0 & 0 & 0 & 0 & 1 & 3544 \\
\hline 2016 & 977 & 100 & 2534 & 60 & 10 & 0 & 15 & 0 & 0 & 0 & 0 & 0 & 3696 \\
\hline 2017 & 914 & 182 & 2855 & 69 & 18 & 0 & 6 & 1 & 0 & 0 & 0 & 0 & 4045 \\
\hline 2018 & 1719 & 156 & 2577 & 112 & 1 & 0 & 0 & 0 & 0 & 0 & 0 & 0 & 4565 \\
\hline 2019 & 1908 & 100 & 2549 & 130 & 24 & 0 & 49 & 0 & 0 & 0 & 0 & 0 & 4760 \\
\hline 2020 & 2189 & 162 & 3078 & 192 & 6 & 0 & 54 & 6 & 0 & 0 & 0 & 0 & 5687 \\
\hline
\end{tabular}

Bron: https://www.wur.nl/nl/Onderzoek-Resultaten/Onderzoeksinstituten/marine-research/showmarine/Populatie-Grijze-Zeehonden-in-de-Nederlandse-Waddenzee.htm 


\section{Bijlage 9 Verspreidingskaarten vogels}

In deze bijlage staan verspreidingskaarten voor de volgende vogelsoorten:

Roodkeelduiker

Parelduiker

Aalscholver

Eider

Zwarte zee-eend

Dwergmeeuw

Kleine mantelmeeuw

Voor de duikers (Gavia spec., waaronder roodkeelduiker en parelduiker), aalscholver, eider, zwarte zee-eend en dwergmeeuw zijn er kaarten voor het NCP afkomstig uit Van der Wal et al. (2018) en Leopold et al. (2014) met dichtheden weergegeven met een kleur code zoals hieronder (Box 1.)

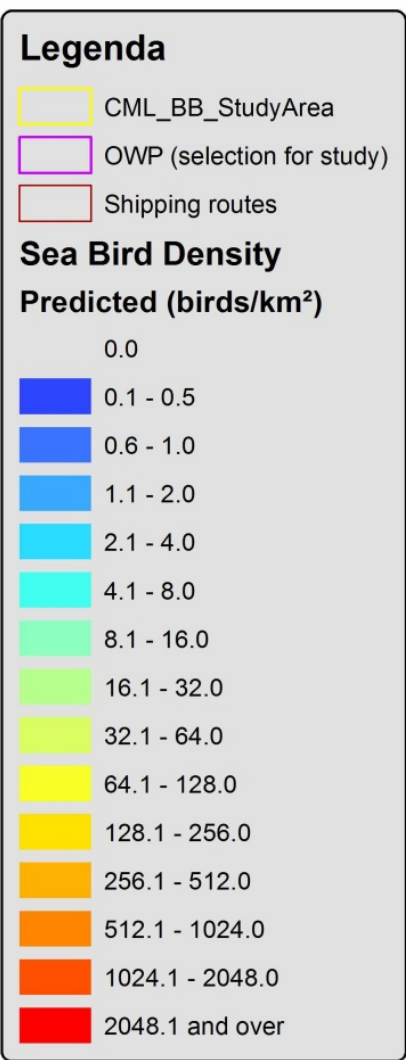

Box 1. Kleur codes gebruikt voor dichtheden van vogelsoorten in Figuur $18 \mathrm{t} / \mathrm{m}$ Figuur 22

\section{Bronnen}

Leopold, M.F., M. Boonman, M.P. Collier, N. Davaasuren, R.C. Fijn, A. Gyimesi, J. de Jong, R.H. Jongbloed, B. Jonge Poerink, J.C. Kleyheeg-Hartman, K.L. Krijgsveld, S. Lagerveld, R. Lensink, M.J.M. Poot, J.T. van der Wal \& M. Scholl (2014): A first approach to deal with cumulative effects on birds and bats of offshore wind farms and other human activities in the Southern North Sea. IMARES report C166/14.

van der Wal, J.T., M.E.B. van Puijenbroek \& M.F. Leopold, 2018. Cumulatieve effecten van offshore wind parken: habitatverlies zeevogels. Update voor vijf zeevogelsoorten, met vooruitblik tot 2030. Wageningen Marine Research, Wageningen. Wageningen Marine Research rapport C059/18. 

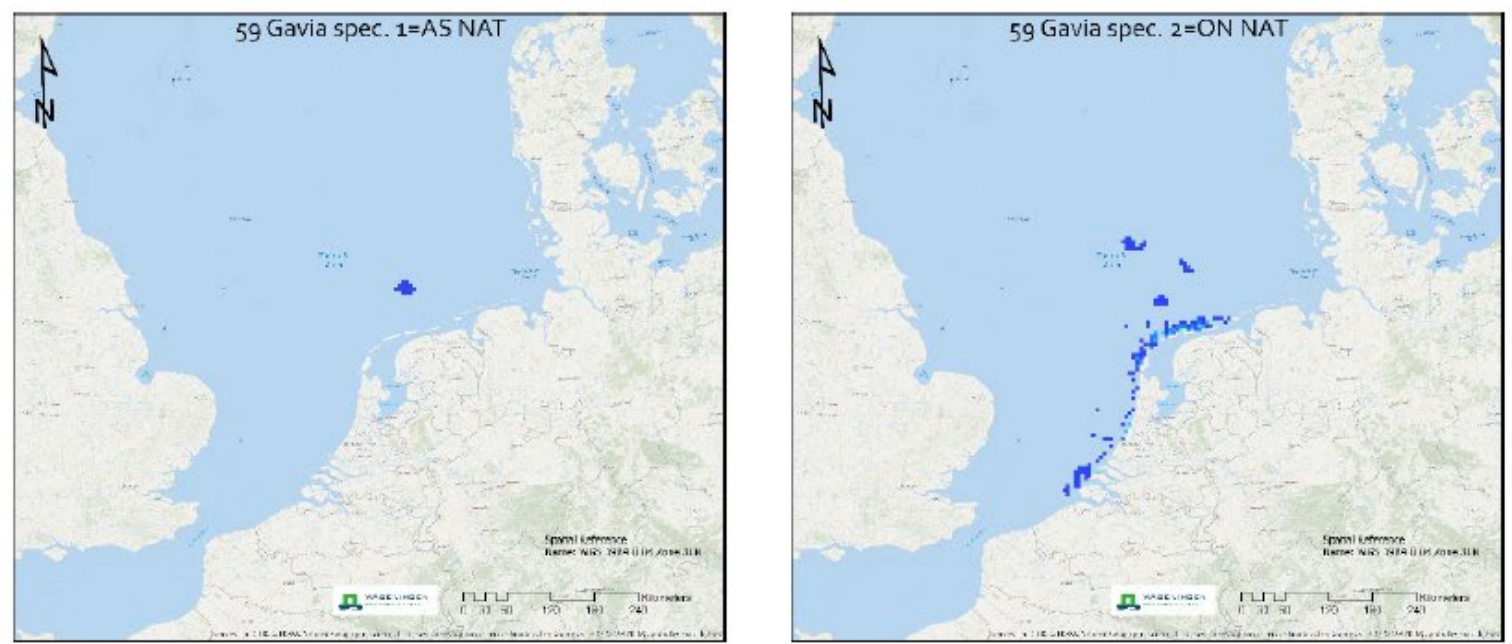

Legenda

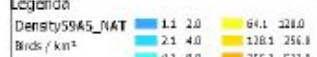

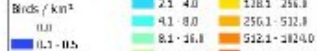

E

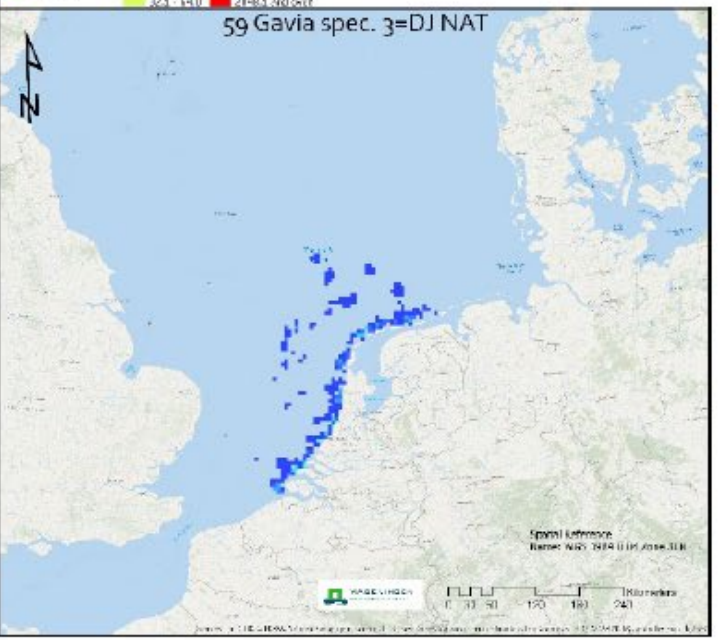

Legenda

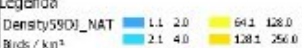

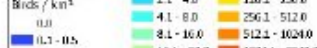

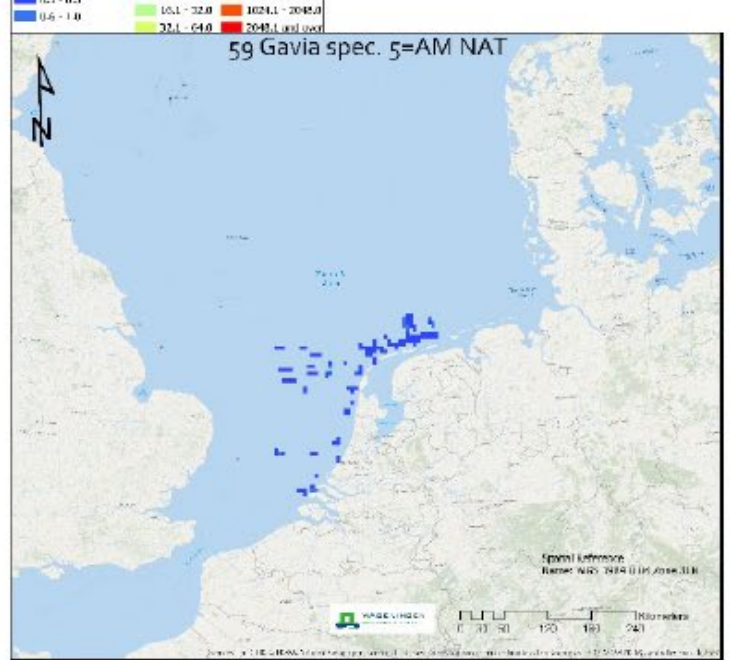

Legenda

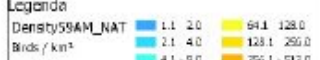

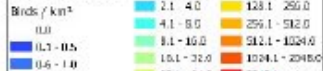

--
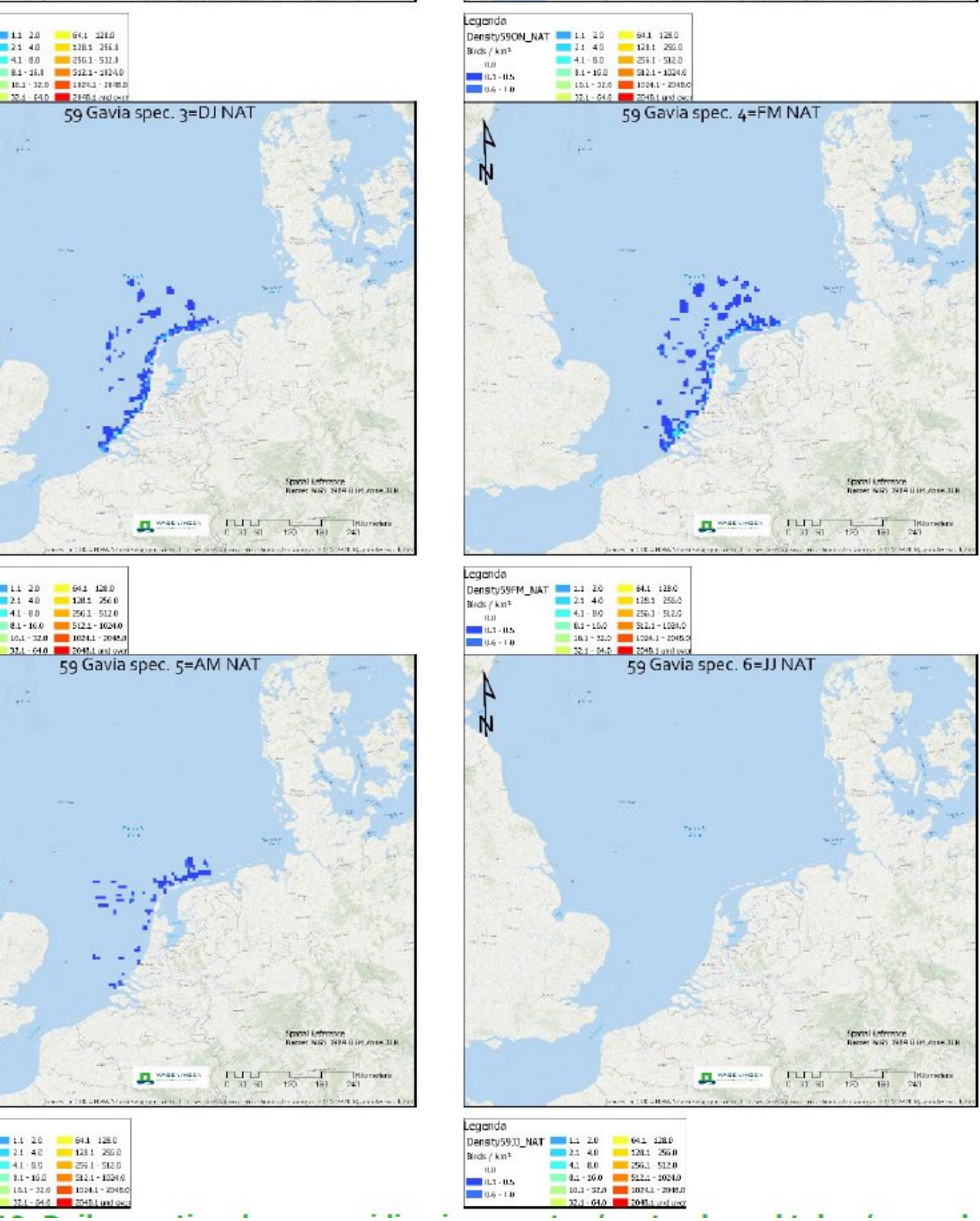

=

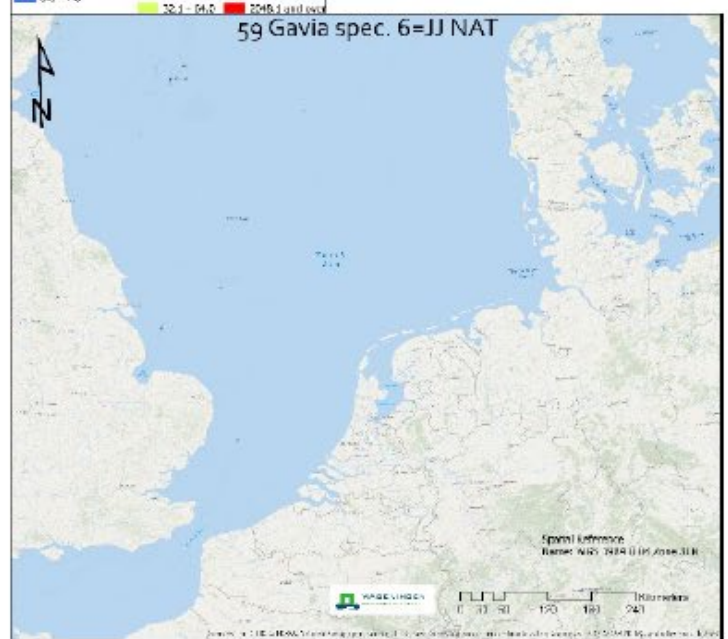

Legenda

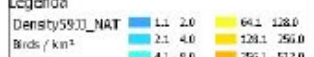

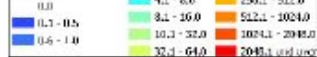

Figuur 18 Duikers (Gavia spec.): nationale verspreiding in augustus/september, oktober/november, december/januari, februari/maart, april/mei en juni/juli, van linksboven naar rechtsonder. Bron: Van der Wal et al. (2018). 

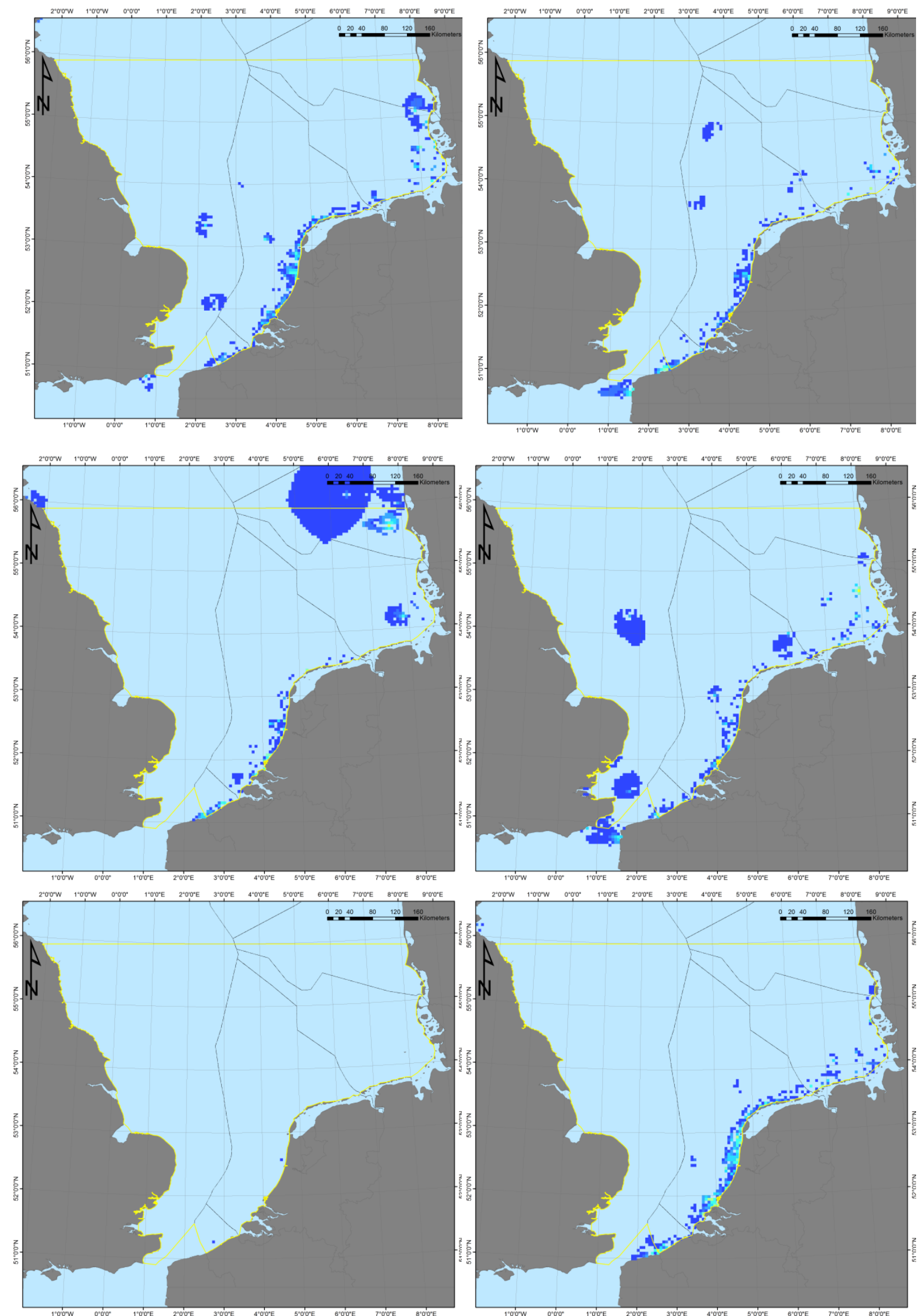

Figuur 19 Aalscholver. Verspreidingspatronen in augustus/september, oktober/november, december/januari, februari/maart, april/mei en juni/juli, in volgorde van boven links naar onder rechts. Voor sleutel tot kleuren die de dichtheden weergeven: zie Box 1. Bron: Leopold et al. (2014). 

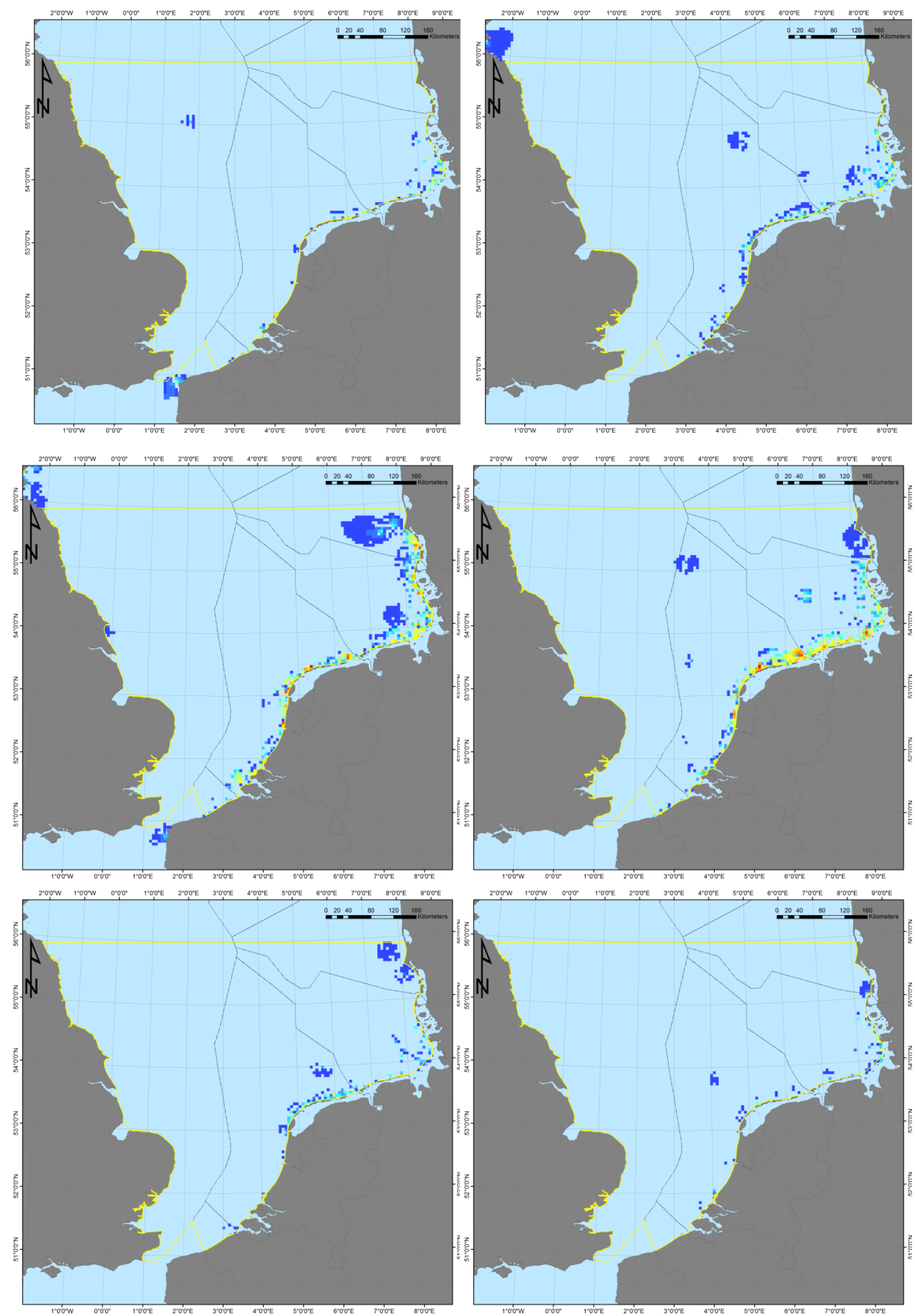

Figuur 20 Eider. Verspreidingspatronen in augustus/september, oktober/november, december/januari, februari/maart, april/mei en juni/juli, in volgorde van boven links naar onder rechts. Voor sleutel tot kleuren die de dichtheden weergeven: zie Box 1. Bron: Leopold et al. (2014). 

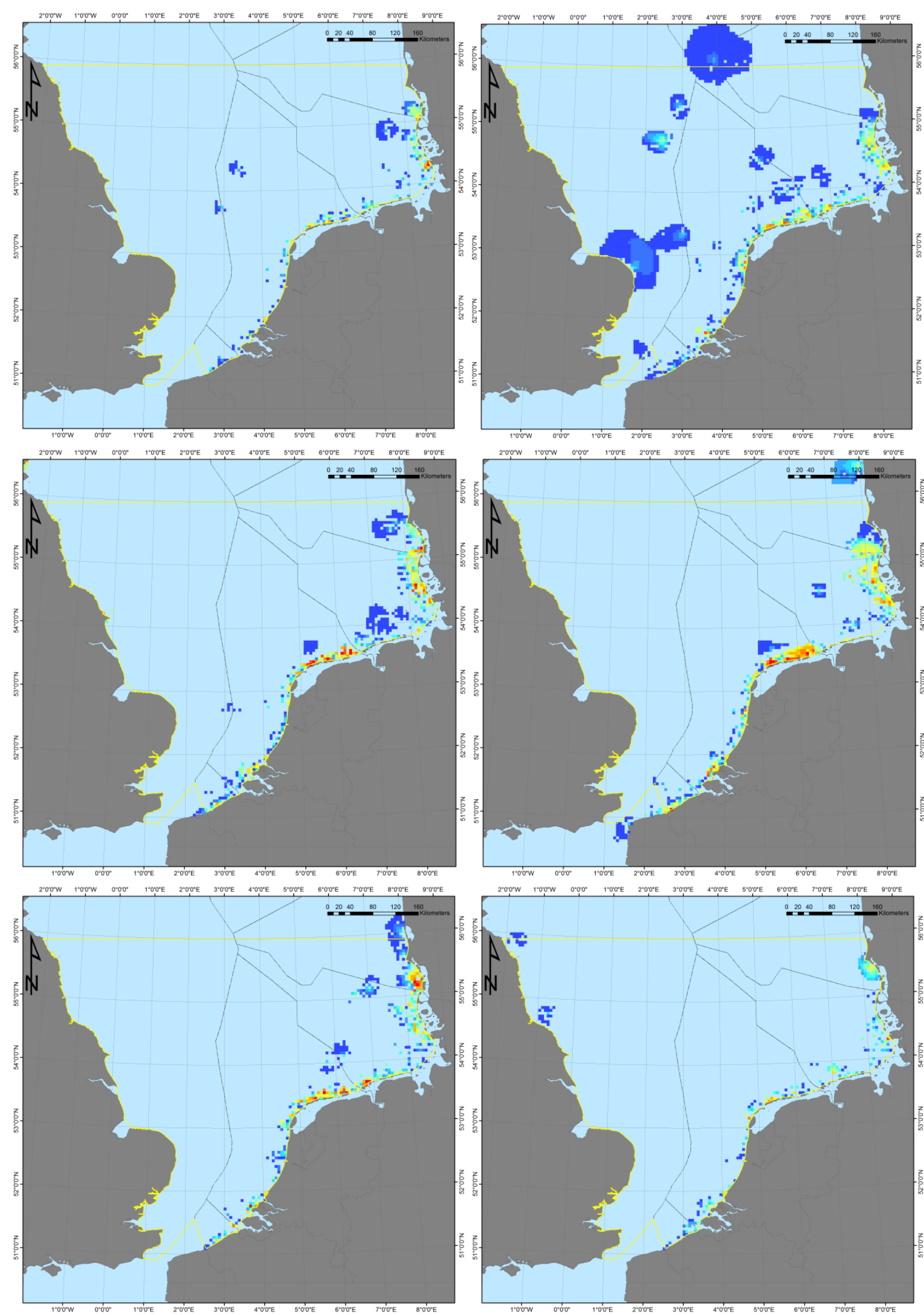

Figuur 21 Zwarte zee-eend. Verspreidingspatronen in augustus/september, oktober/november, december/januari, februari/maart, april/mei en juni/juli, in volgorde van boven links naar onder rechts. Voor sleutel tot kleuren die de dichtheden weergeven: zie Box 1. Bron: Leopold et al. (2014). 

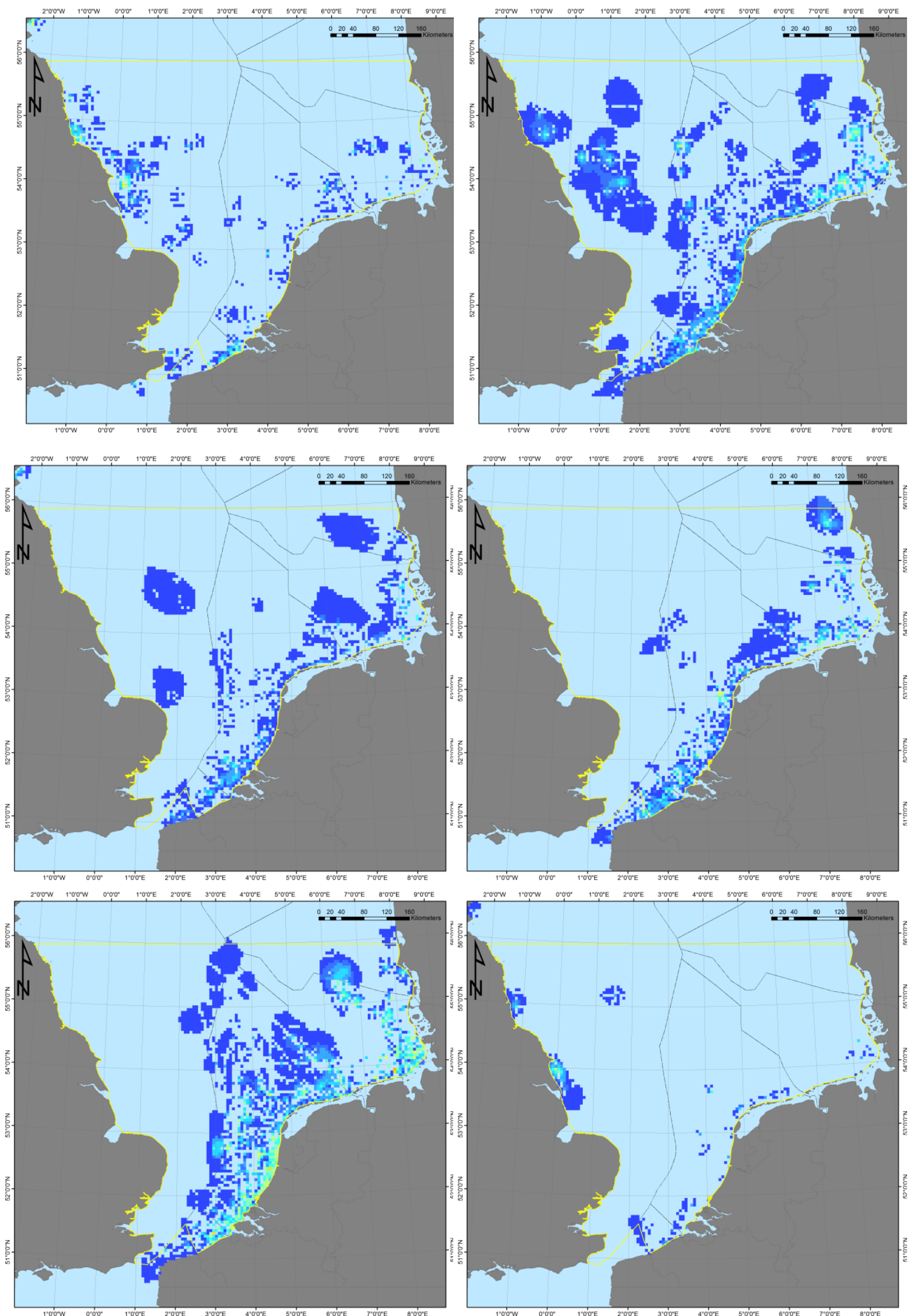

Figuur 22 Dwergmeeuw. Verspreidingspatronen in augustus/september, oktober/november, december/januari, februari/maart, april/mei en juni/juli, in volgorde van boven links naar onder rechts. Voor sleutel tot kleuren die de dichtheden weergeven: zie Box 1. Bron: Leopold et al. (2014).

In het studiegebied van de Slow Mill varieert de dichtheid van de duikers tussen 4 categorieën: 0.0 , $0.1-0.5,0.6-1.0,1.1-2.0$. 


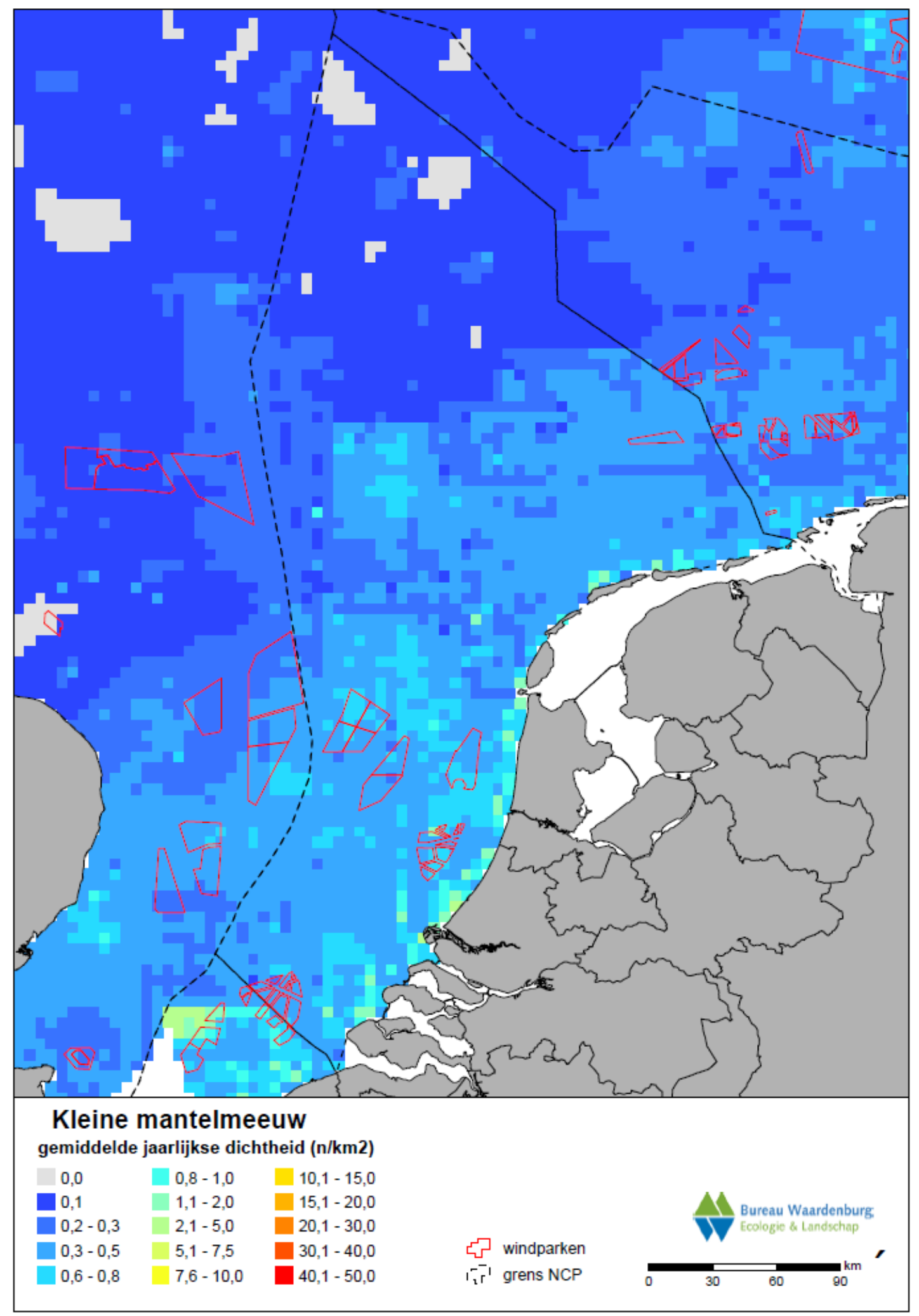

Figuur 23 Langjarige (periode 2000-2017) seizoensgemiddelde dichtheden van kleine mantelmeeuwen in de Nederlandse Noordzee in en om offshore windparkgebieden. Bron: Gyimesi et al. (2018)

Gyimesi, A., J.W. de Jong, A. Potiek \& E.L. Bravo Rebolledo 2018. Actualisatie van KEC vogelaanvaring berekeningen volgens Routekaart 2030. Rapportnr. 18-290. Bureau Waardenburg, Culemborg.

In het studie gebied van de Slow Mill varieert de dichtheid van de kleine mantelmeeuw tussen 3 categorieën: $0.2-0.3,0.3-0.5,0.6-0.8$. 
Meer ruimtelijk gedetailleerde verspreidingskaarten die relevant zijn voor vogels in het studiegebied van deze PB, zijn beschikbaar voor aalscholver, eider en kleine mantelmeeuw. Deze staan hieronder.

\section{Aalscholver}

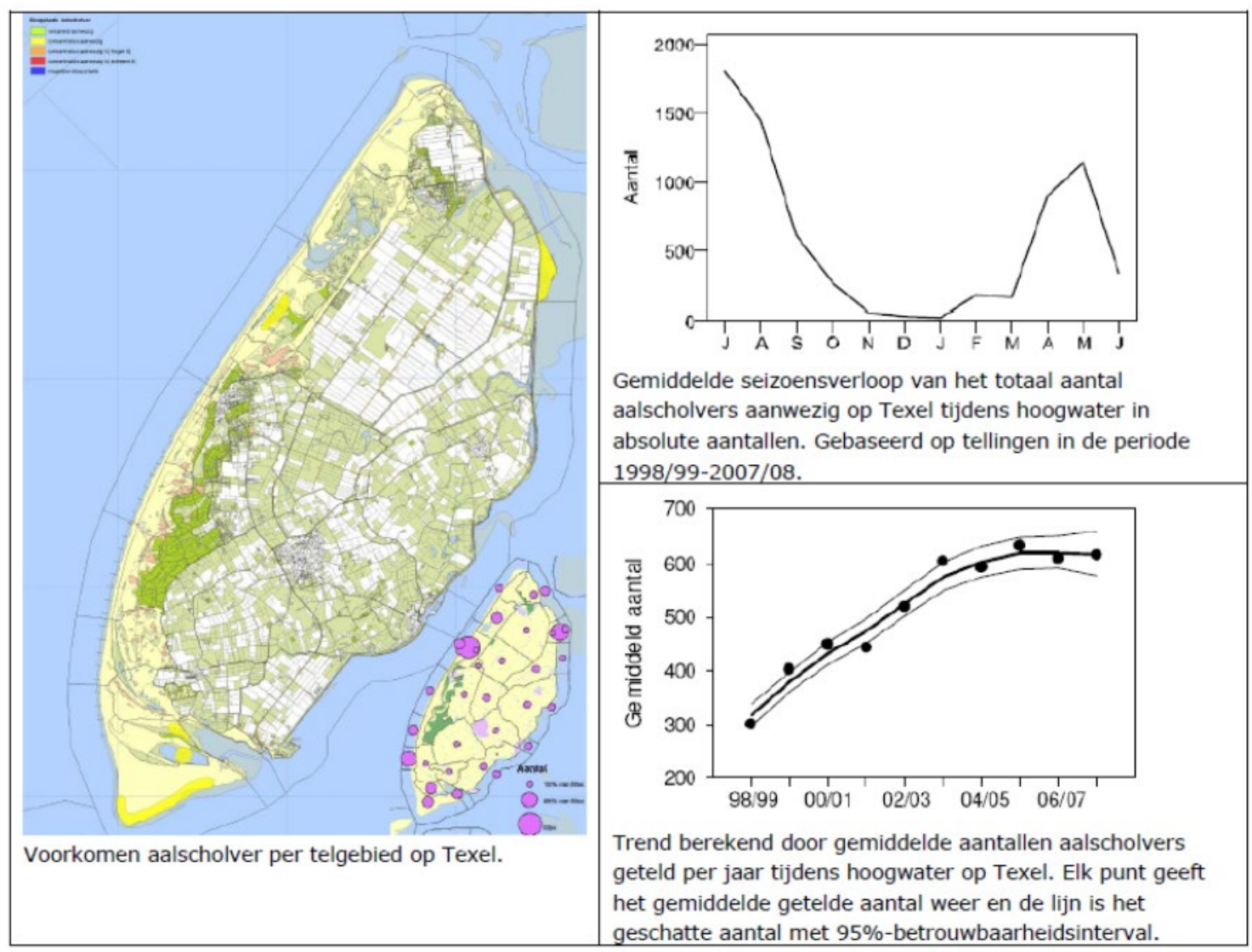

Verspreidingskaarten en trends van vogelsoorten op Texel met een instandhoudingsdoelstelling voor de Noordzeekustzone (Beheerplan Texel (2016))

\section{Eider}

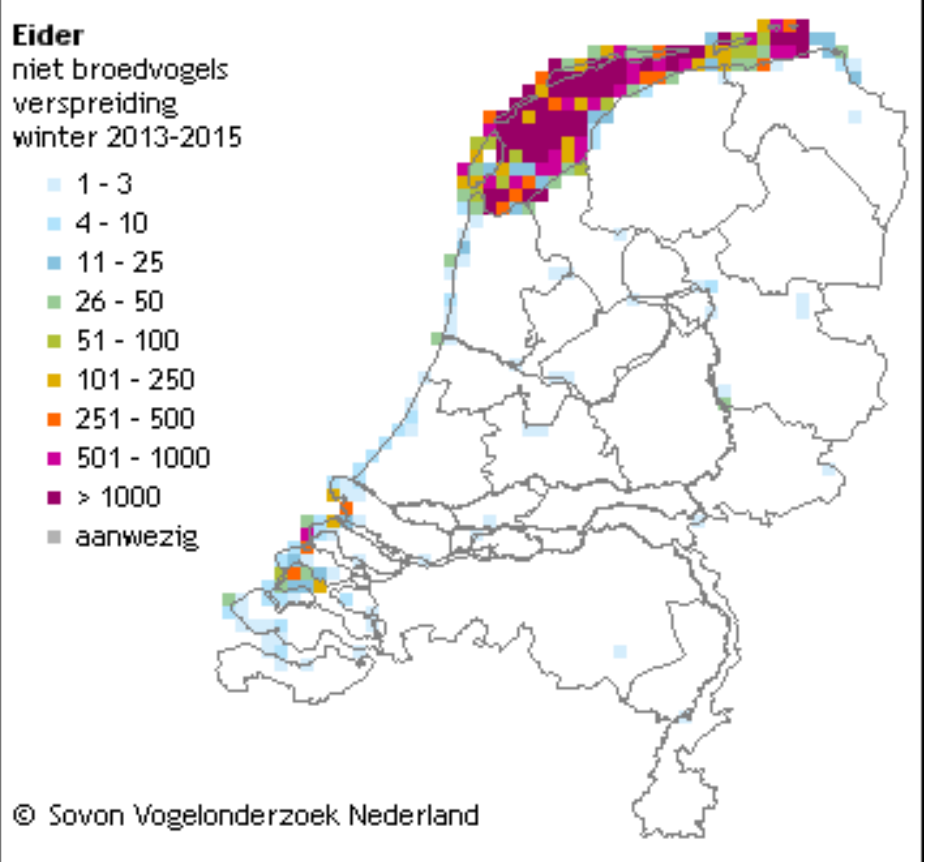


Verspreidingskaartjes van vogels van www.sovon.nl

Opgezocht juni 2020

\section{Kleine mantelmeeuw}

\begin{tabular}{|l|l|l|}
\hline \\
\hline
\end{tabular}




\section{Bijlage 10 Trends voor vogels in relevante Natura 2000-gebieden}

Gegevens betrokken van www.sovon.nl

Trendgrafieken van drie vogelsoorten (aalscholver, eider, zwarte zee-eend) van Natura 2000-gebied Noordzeekustzone en een vogelsoort (kleine mantelmeeuw) van Natura 2000-gebied Duinen en Lage Land Texel gedownload van www.sovon.nl op 10-12-2020
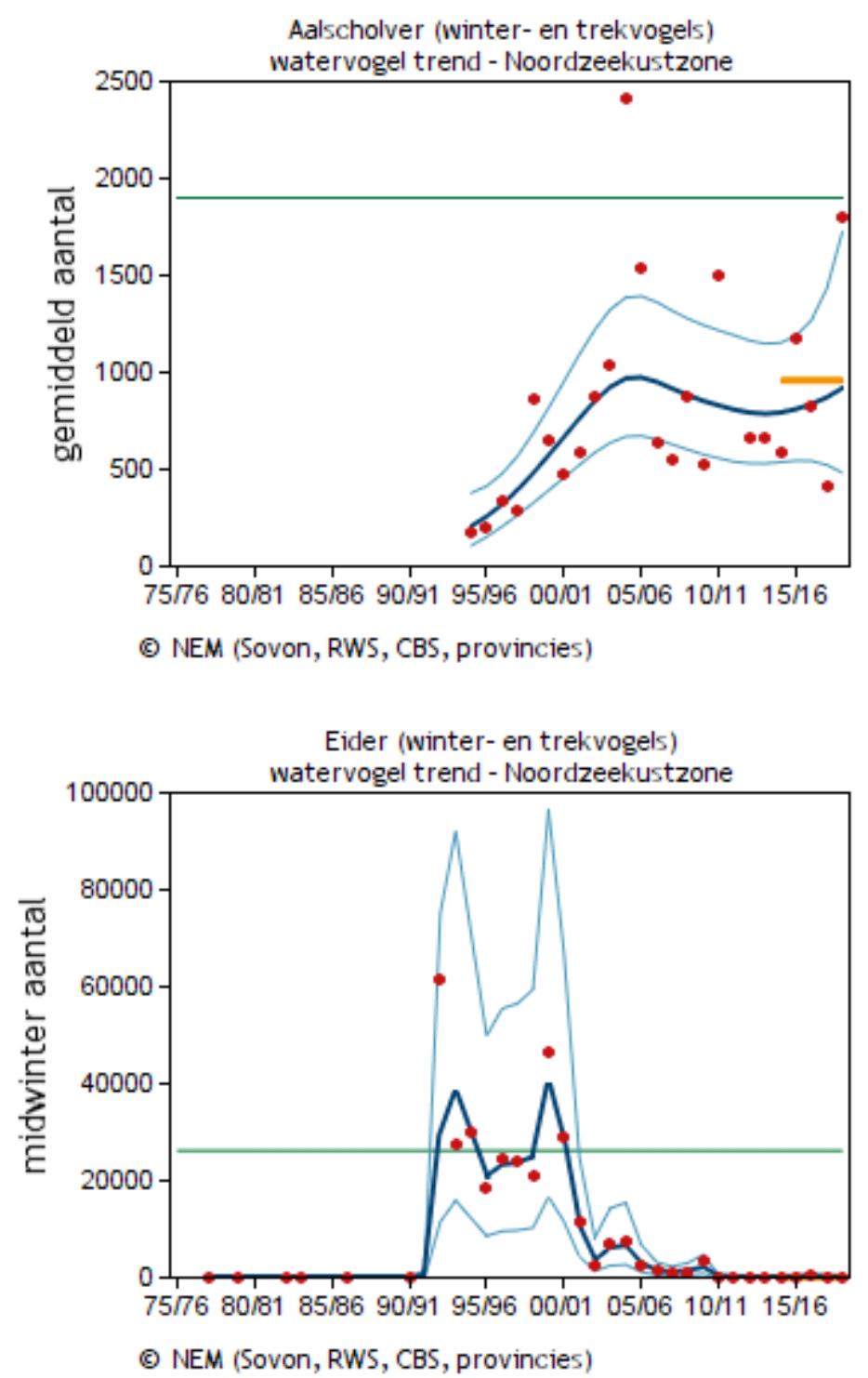


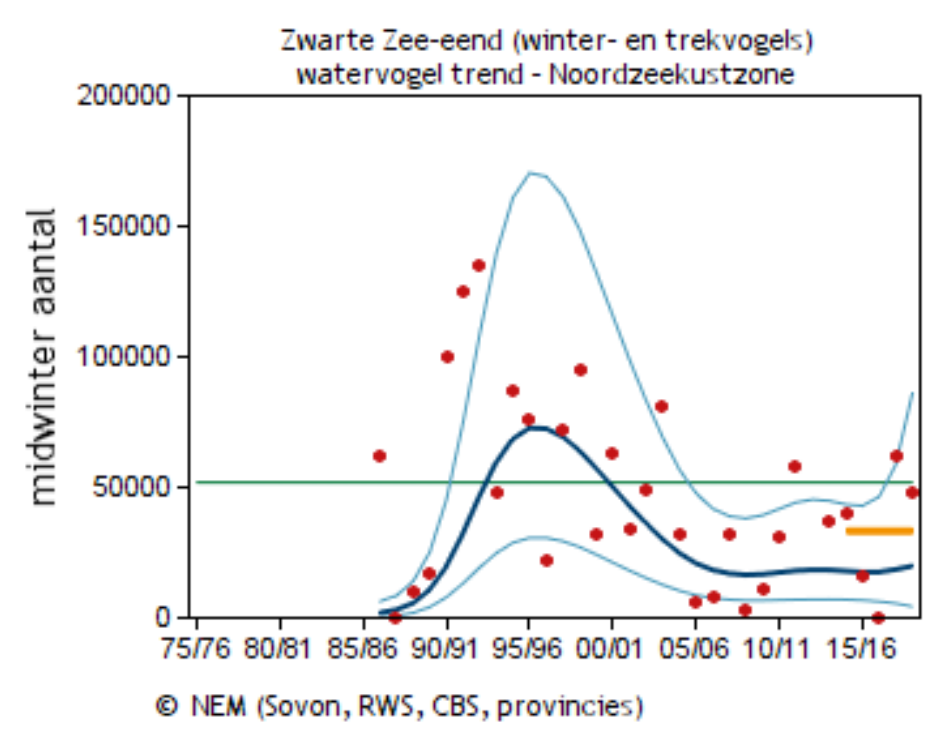

Deze grafiek is gebaseerd op het Meetnet Watervogels Weergegeven is het aantal vogels in januari (rode punten), de trendlijn (donker gekleurde lijn) en het $95 \%$ betrouwbaarheidsinterval van de trendlijn (lichtgekleurde lijn). In groen wordt de instandhoudingsdoelstelling voor de soort weergegeven. De oranje lijn geeft het gemiddelde over de laatste vijf seizoenen, analoog aan de werkwijze zoals die binnen Natura 2000 wordt gebruikt om de actuele situatie te beschrijven (Leidraad bepaling significantie). Doelen kunnen veranderen, voor actuele doelen wordt daarom verwezen naar het Ministerie van Landbouw, Natuur en Voedselkwaliteit. Project informatie Gegevens verwerkt tot en met 1-9-2020

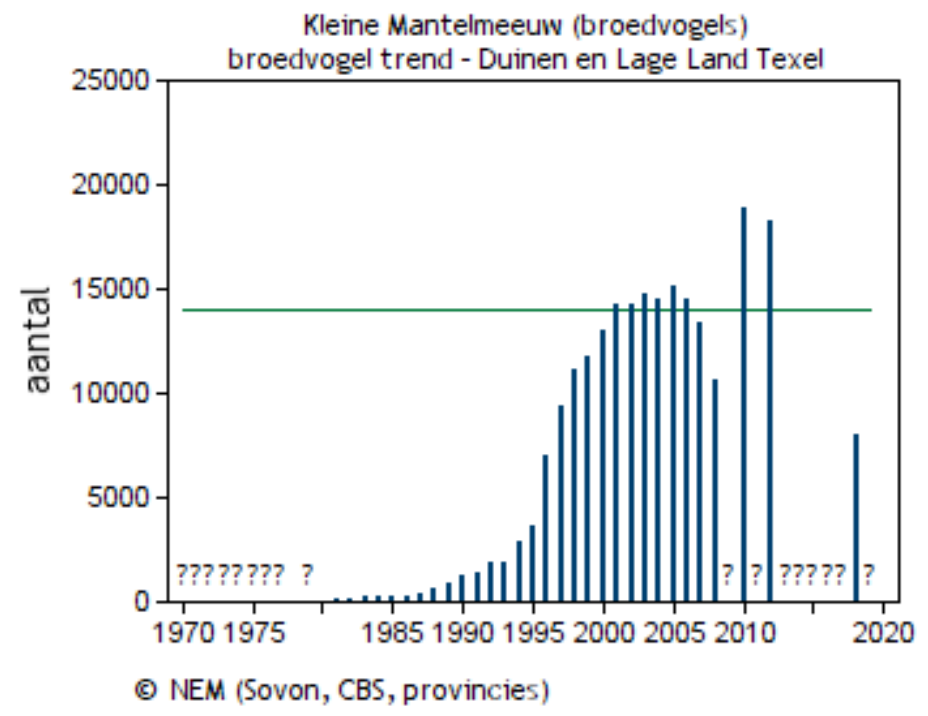

vanaf 1990: $\quad$ significante toename, $<5 \%$ per jaar $(+)$ laatste 12 jaren: $\quad$ significante afname, $<5 \%$ per jaar (-)

Deze grafiek is gebaseerd op het Meetnet Broedvogels (kolonies en zeldzame broedvogels). Weergegeven is het jaarlijks aantal broedvogels/territoria. In groen wordt de instandhoudingsdoelstelling voor de soort weergegeven. Indien er geen groene lijn wordt getoond is er geen instandhoudingsdoelstelling bekend voor het gebied omdat er een doelstelling is geformuleerd voor een grotere regio (IJsselmeergebied, Deltagebied) of omdat de doelstelling hervestiging van de soort is (Veluwe). De oranje lijn geeft het gemiddelde over de laatste vijf jaren (alleen indien uit minimaal drie jaren tellingen beschikbaar zijn), analoog aan de werkwijze zoals die binnen Natura 2000 wordt gebruikt om de actuele situatie te beschrijven (Leidraad bepaling significantie). Doelen kunnen veranderen, voor actuele doelen wordt daarom verwezen naar het Ministerie van Landbouw, Natuur en Voedselkwaliteit. Project informatie Gegevens verwerkt tot en met 1-9-2020 


\section{Natura 2000-gebied Noordzeekustzone (7)}

\section{Winter en trekvogels}

Voor deze PB geselecteerd op de zes relevante soorten

\begin{tabular}{|c|c|c|c|c|c|c|c|c|c|c|c|}
\hline Soort & Functie & Aantal in & $13 / 14$ & $14 / 15$ & $15 / 16$ & $16 / 17$ & $17 / 18$ & $18 / 19$ & $\begin{array}{l}\text { Start } \\
\text { trend }\end{array}$ & $\begin{array}{l}\text { Trend } \\
\text { sinds } \\
\text { start }\end{array}$ & $\begin{array}{l}\text { Trend } \\
\text { sinds } \\
07 / 08\end{array}$ \\
\hline Aalscholver & $f$ & seiz.gem. & 656 & 584 & 1175 & 821 & 418 & 1799 & 1994 & + & $\sim$ \\
\hline Aalscholver & $\mathrm{s}$ & seiz.max. & $?$ & $?$ & $?$ & $?$ & $?$ & $?$ & 1999 & + & \\
\hline Dwergmeeuw & $f$ & seiz.gem. & $?$ & $?$ & $?$ & $?$ & $?$ & $?$ & & & \\
\hline Eider & $f$ & midwinter & 0 & 9 & 63 & 319 & 75 & 20 & 1980 & + & -- \\
\hline Parelduiker & $f$ & seiz.gem. & $?$ & $?$ & $?$ & $?$ & $?$ & $?$ & & & \\
\hline Roodkeelduiker & $f$ & seiz.gem. & $?$ & $?$ & $?$ & $?$ & $?$ & $?$ & & & \\
\hline $\begin{array}{l}\text { Zwarte Zee- } \\
\text { eend }\end{array}$ & $f$ & midwinter: & 37078 & 39631 & 15978 & 403 & 61841 & 48475 & 1986 & + & $\sim$ \\
\hline
\end{tabular}

(C) Netwerk Ecologische Monitoring

(Sovon, RWS, CBS, provincies)

\section{Natura 2000-gebied Duinen en Lage Land Texel (2)}

\section{Broedvogels}

Voor deze PB geselecteerd op de relevante soort: kleine mantelmeeuw

Soort Functie $\begin{aligned} & \text { Aantal } \\
& \text { in }\end{aligned}$
\begin{tabular}{|l|c|c|c|c|c|c|c|c|c|c|c|c|c|c|}
\hline $\begin{array}{l}\text { Kleine } \\
\text { Mantelmeeuw }\end{array}$ & b & paren & $?$ & $?$ & $?$ & $?$ & 7996 & $?$ & 1990 & + & $\begin{array}{l}\text { Start } \\
\text { trend }\end{array}$ & $\begin{array}{l}\text { Trend } \\
\text { sinds } \\
\text { start }\end{array}$ & $\begin{array}{l}\text { Trend } \\
\text { sinds } \\
2008\end{array}$ \\
\hline
\end{tabular}

(C) Netwerk Ecologische Monitoring

(Sovon, RWS, CBS, provincies)

Toelichting:

Gebiedsdoel: voor deze soorten zijn instandhoudingsdoelen geformuleerd of worden aanvullende specifieke functies aangegeven in de toelichting op de doelen. Zie voor de actuele stand van zaken van gebiedsdoelen en doelformuleringen de aanwijzingsbesluiten.

Functie: b broeden, f foerageren, s slapen (slaapplaats)

Aantal in: de aantallen worden per jaar (broedvogels) of per seizoen (winter- en trekvogels) gepresenteerd. Een seizoen loopt van juli tot en met juni. Bij broedvogels gaat het om het aantal broedparen, bij winter- en trekvogels om het gemiddelde maandelijkse aantal per seizoen (seiz. gem. = seizoensgemiddelde) of het maximale aantal binnen een seizoen (seiz. max. = seizoensmaximum). Deze keuze hangt samen met de wijze waarop de instandhoudingsdoelen worden uitgedrukt: bij slaapplaatsen zijn dit bijvoorbeeld seizoensmaxima. In incidentele gevallen wordt alleen een aantal uit januari gepresenteerd (midwinter). 
Bij aantallen tussen vierkante haakjes waren geen volledige tellingen beschikbaar en wordt een schatting gegeven. In het geval van accolades betreft de schatting een gemiddelde over het betreffende jaar en de twee omliggende jaren. In gevallen waar een vraagteken wordt vermeld, zijn vaak wel steekproeven van een deel van het gebied beschikbaar maar geen (betrouwbare) totaalschatting.

Trend: trends zijn gebaseerd op volledige tellingen of, indien niet beschikbaar, een representatieve steekproef van telgebieden. Trends worden weergegeven voor de lange termijn (startjaar aangegeven) en voor de laatste tien (broedvogels) of twaalf (watervogels) jaar.

Gebruikte trend-symbolen:

++ significante sterke toename van $>5 \%$ per jaar

+ significante matige toename van $<5 \%$ per jaar

0 stabiel, geen significante trend

- matige significante afname van $<5 \%$ per jaar

-- sterke significante afname van $>5 \%$ per jaar

$\sim$ onzeker, geen trend aantoonbaar 


\section{Bijlage 11 Kwetsbaarheid index van vogelsoorten voor WECs}

Overzicht van de kwetsbaarheid index voor WECS (Wave energy converters) van alle door Furness et al. (2012) beoordeelde vogelsoorten in de Schotse wateren. Bron: Furness et al. (2012) waarin ook de methode volledig is beschreven.

Table 2. Species vulnerability index for wave energy device impacts on seabirds (ranked by species score).

\begin{tabular}{lll}
\hline Species & Score & Descriptor on 5-score scale \\
\hline Red-throated diver & 288 & 3: moderate vulnerability \\
Black-throated diver & 288 & 3: moderate vulnerability \\
Great northern diver & 270 & 3: moderate vulnerability \\
Razorbill & 192 & 2: low vulnerability \\
Common scoter & 180 & 2: low vulnerability \\
Common guillemot & 176 & 2: low vulnerability \\
Black guillemot & 169 & 2: low vulnerability \\
Slavonian grebe & 169 & 2: low vulnerability \\
Shag & 165 & 2: low vulnerability \\
Atlantic puffin & 160 & 2: low vulnerability \\
Little tern & 156 & 2: low vulnerability \\
Greater scaup & 154 & 2: low vulnerability \\
Velvet scoter & 154 & 2: low vulnerability \\
Arctic tern & 153 & 2: low vulnerability \\
Common goldeneye & 144 & 2: low vulnerability \\
Northern gannet & 136 & 2: low vulnerability \\
Roseate tern & 135 & 2: low vulnerability \\
Common eider & 130 & 2: low vulnerability \\
Common tern & 126 & 2: low vulnerability \\
Sandwich tern & 125 & 2: low vulnerability \\
Great cormorant & 110 & 2: low vulnerability \\
Manx shearwater & 102 & 2: low vulnerability \\
Black-legged kittiwake & 98 & 1: very low vulnerability \\
Long-tailed duck & 96 & 1: very low vulnerability \\
Great skua & 96 & 1: very low vulnerability \\
Great-crested grebe & 91 & 1: very low vulnerability \\
Arctic skua & 84 & 1: very low vulnerability \\
Little auk & 81 & 1: very low vulnerability \\
Northern fulmar & 80 & 1: very low vulnerability \\
Great black-backed gull & 75 & 1: very low vulnerability \\
Sooty shearwater & 72 & 1: very low vulnerability \\
White-tailed eagle & 72 & 1: very low vulnerability \\
European storm-petrel & 68 & 1: very low vulnerability \\
Common gull & 65 & 1: very low vulnerability \\
Lesser black-backed gull & 64 & 1: very low vulnerability \\
Leach's storm-petrel & 64 & 1: very low vulnerability \\
Black-headed gull & 60 & 1: very low vulnerability \\
Herring gull & 48 & 1: very low vulnerability \\
\hline
\end{tabular}

Bron:

Furness, R.W., Wade, H.M., Robbins, A.M.C. \& Masden, E.A. (2012). Assessing the sensitivity of seabird populations to adverse effects from tidal stream turbines and wave energy devices ICES Journal of Marine Science. doi.org/10.1093/icesjms/fss131 


\section{Bijlage 12 AERIUS ${ }^{\circledR}$-Calculator resultaten voor de verwachte stikstofuitstoot van de voorgenomen activiteiten}

De rekenresultaten van de AERIUS Calculator voor de bouwfase, operationele fase en ontmantelingsfase van Elias Consulting $(2021 a, b, c)$ zijn hieronder weergegeven. 


\section{AERIUS À CALCULATOR}

Dit document bevat rekenresultaten van AERIUS Calculator. Het betreft de hoogst berekende stikstofbijdragen per

stikstofgevoelig Natura 2000-gebied, op basis van rekenpunten die overlappen met habitattypen en/of leefgebieden die aangewezen zijn in het kader van de Wet natuurbescherming, gekoppeld aan een aangewezen soort, of nog onbekend maar mogelijk wel relevant.

De berekening op basis van stikstofemissies gaat uit van de componenten ammoniak (NHz) en/of stikstofoxide (NOx).

Wilt u verder rekenen of gegevens wijzigen? Importeer de pdf dan in Calculator. Voor meer toelichting verwijzen wij u naar de website www.aerius.nl.
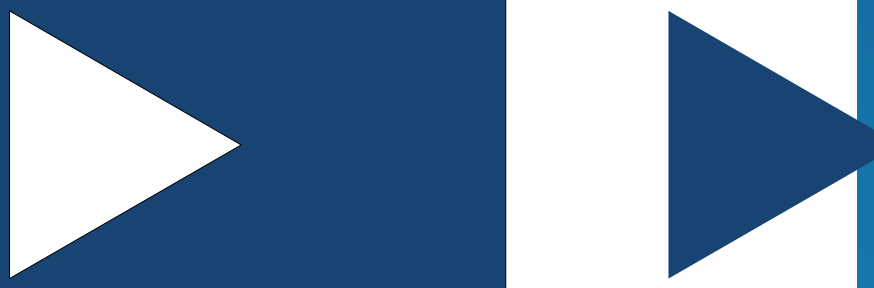

Berekening Situatie 1

- Kenmerken

- Samenvatting emissies

- Depositieresultaten

- Gedetailleerde emissiegegevens

Verdere toelichting over deze PDF kunt u vinden in een bijbehorende leeswijzer. Deze leeswijzer en overige documentatie is te raadplegen via:

https://www.aerius.nl/handleidingen-en-leeswijzers. 
Resultaten

\section{AERIUS Â CALCULATOR}

\section{Contact}

Rechtspersoon

Slow Mill Sustainable Power BV

Activiteit

Omschrijving

Pilot Slow Mill

Datum berekening

15 juni 2021, 11:25

Situatie 1

$\mathrm{NOx}$

$145,82 \mathrm{~kg} / \mathrm{j}$

$\mathrm{NH}_{3}$

Inrichtingslocatie

4 km ten westen van Texel (Paal 19), 1796AA Texel

AERIUS kenmerk

RoJwKnefvSdc

Rekenjaar

2022
Rekenconfiguratie

Berekend voor natuurgebieden

Totale emissie

Resultaten

Hectare met hoogste bijdrage (mol/ha/j)

Toelichting
Natuurgebied

Uw berekening heeft geen depositieresultaten opgeleverd boven o,0o mol/ha/jr. 


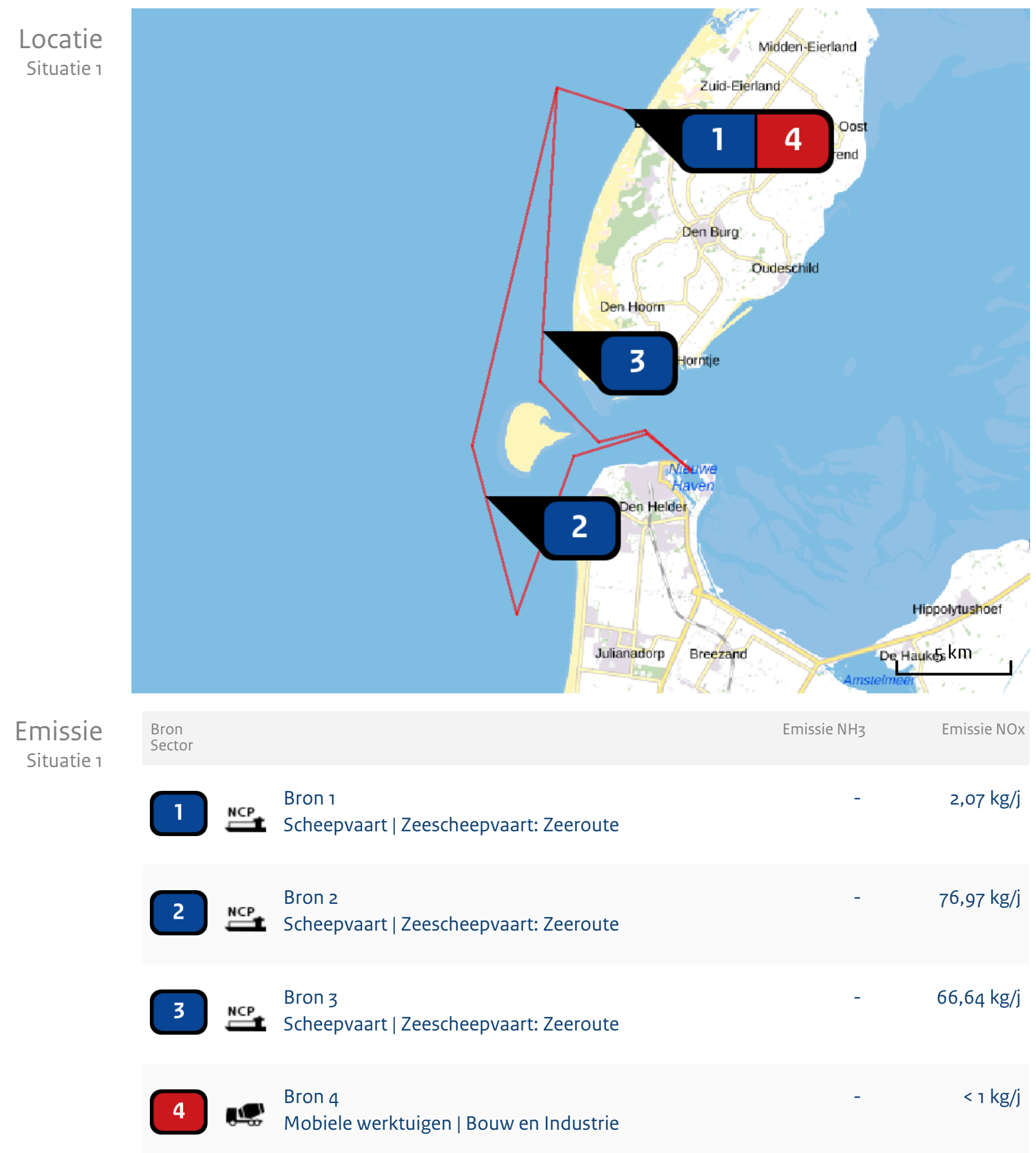




\author{
Emissie \\ (per bron) \\ Situatie 1
}

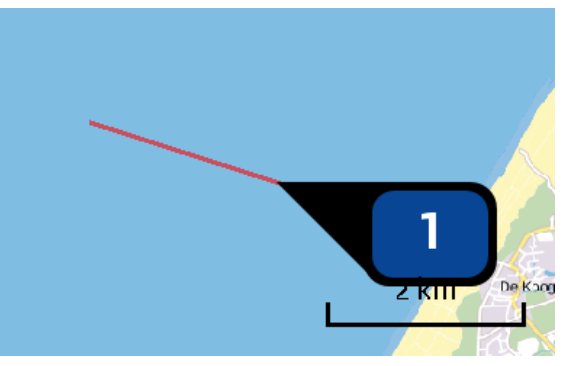

Naam

Locatie $(X, Y)$

NOx

Omschrijving

M/V RAM

Sleepboten,

werkschepen en

overige GT: 100-1599

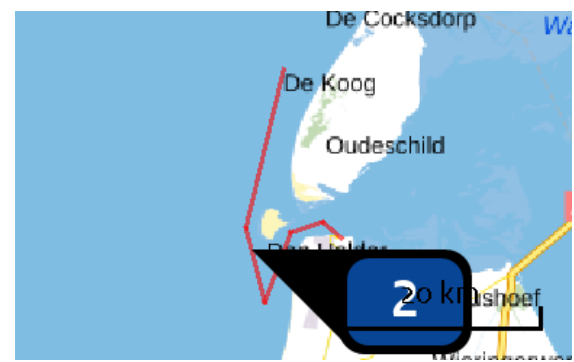

Naam

Locatie $(X, Y)$

NOx

Omschrijving

M/V RAM

Sleepboten,

werkschepen en

overige GT: 100-1599

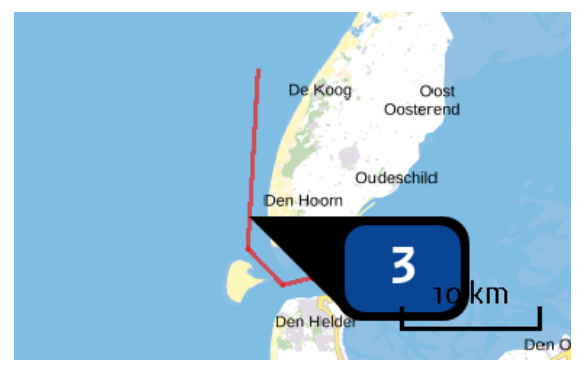

Naam

Locatie $(X, Y)$

NOx
Omschrijving

Empiric
Sleepboten,

werkschepen en

overige GT: 100-1599

Scheepstype

\section{Bron 1}

110797, 569172

2,07 kg/j
Aantal bezoeken Stof

1 / jaar NOx
Emissie $2,07 \mathrm{~kg} / \mathrm{j}$
Bron 2

105765,551846

$76,97 \mathrm{~kg} / \mathrm{j}$
Aantal bezoeken Stof

4 / jaar NOx
Emissie

$76,97 \mathrm{~kg} / \mathrm{j}$ 


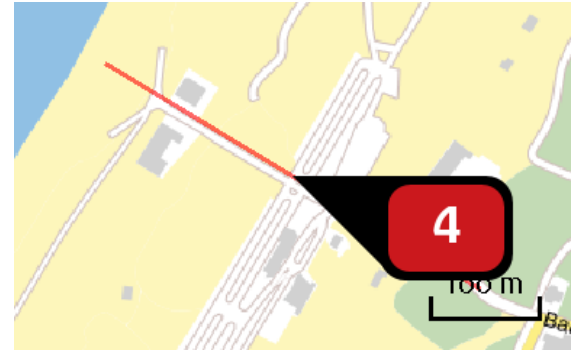

Voertuig

Omschrijving

Graafmachine

STAGE V, LPG 130

$<=\mathrm{kW}<560$,

bouwjaar 2019

(LPG)
Naam Bron 4

Locatie $(X, Y)$

NOx

112864, 568462

$<1 \mathrm{~kg} / \mathrm{j}$
Brandstof Stationair verbruik (I/j)
Cilinder Stof inhoud (I)
Emissie (uren/i)

200

NOx

$<1 \mathrm{~kg} / \mathrm{j}$ 
Hoewel verstrekte gegevens kunnen dienen ter onderbouwing van een vergunningaanvraag, kunnen er geen rechten aan worden ontleend. De eigenaar van AERIUS aanvaardt geen aansprakelijkheid voor de inhoud van de door de gebruiker aangeboden informatie. Bovenstaande gegevens zijn enkel bruikbaar tot er een nieuwe versie van AERIUS beschikbaar is. AERIUS is een geregistreerd handelsmerk in Europa. Alle rechten die niet expliciet worden verleend, zijn voorbehouden.

Rekenbasis Deze berekening is tot stand gekomen op basis van:

AERIUS versie 2020_20210525_2040287d5b

Database versie 2020_20210525_2040287d5b

Voor meer informatie over de gebruikte methodiek en data zie:

https://www.aerius.nl/nl/factsheets/release/aerius-calculator-2020 


\section{AERIUS À CALCULATOR}

Dit document bevat rekenresultaten van AERIUS Calculator. Het betreft de hoogst berekende stikstofbijdragen per

stikstofgevoelig Natura 2000-gebied, op basis van rekenpunten die overlappen met habitattypen en/of leefgebieden die aangewezen zijn in het kader van de Wet natuurbescherming, gekoppeld aan een aangewezen soort, of nog onbekend maar mogelijk wel relevant.

De berekening op basis van stikstofemissies gaat uit van de componenten ammoniak (NHz) en/of stikstofoxide (NOx).

Wilt u verder rekenen of gegevens wijzigen? Importeer de pdf dan in Calculator. Voor meer toelichting verwijzen wij u naar de website www.aerius.nl.
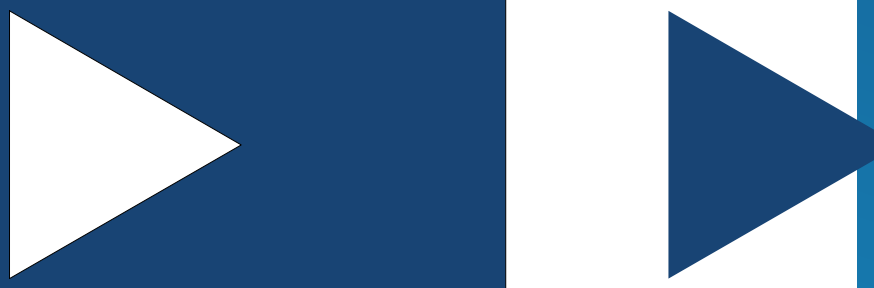

Berekening Situatie 1

- Kenmerken

- Samenvatting emissies

- Depositieresultaten

- Gedetailleerde emissiegegevens

Verdere toelichting over deze PDF kunt u vinden in een bijbehorende leeswijzer. Deze leeswijzer en overige documentatie is te raadplegen via:

https://www.aerius.nl/handleidingen-en-leeswijzers. 
Resultaten

\section{AERIUS Â CALCULATOR}

Contact

Rechtspersoon

Slow Mill Sustainable Power BV

Activiteit

Omschrijving

Pilot Slow Mill

Datum berekening

15 juni 2021, 11:30

Situatie 1

NOx

$88,85 \mathrm{~kg} / \mathrm{j}$

$\mathrm{NH}_{3}$
Inrichtingslocatie

4 km ten westen van Texel (Paal 19), 1796AA Texel

AERIUS kenmerk

S3gLRTA9pyCM

Rekenjaar

Rekenconfiguratie

2022

Berekend voor natuurgebieden

Totale emissie

Resultaten

Hectare met hoogste bijdrage (mol/ha/j)

Toelichting
Natuurgebied

Uw berekening heeft geen depositieresultaten opgeleverd boven o,0o mol/ha/jr.

Vaarwerk; operationele fase 


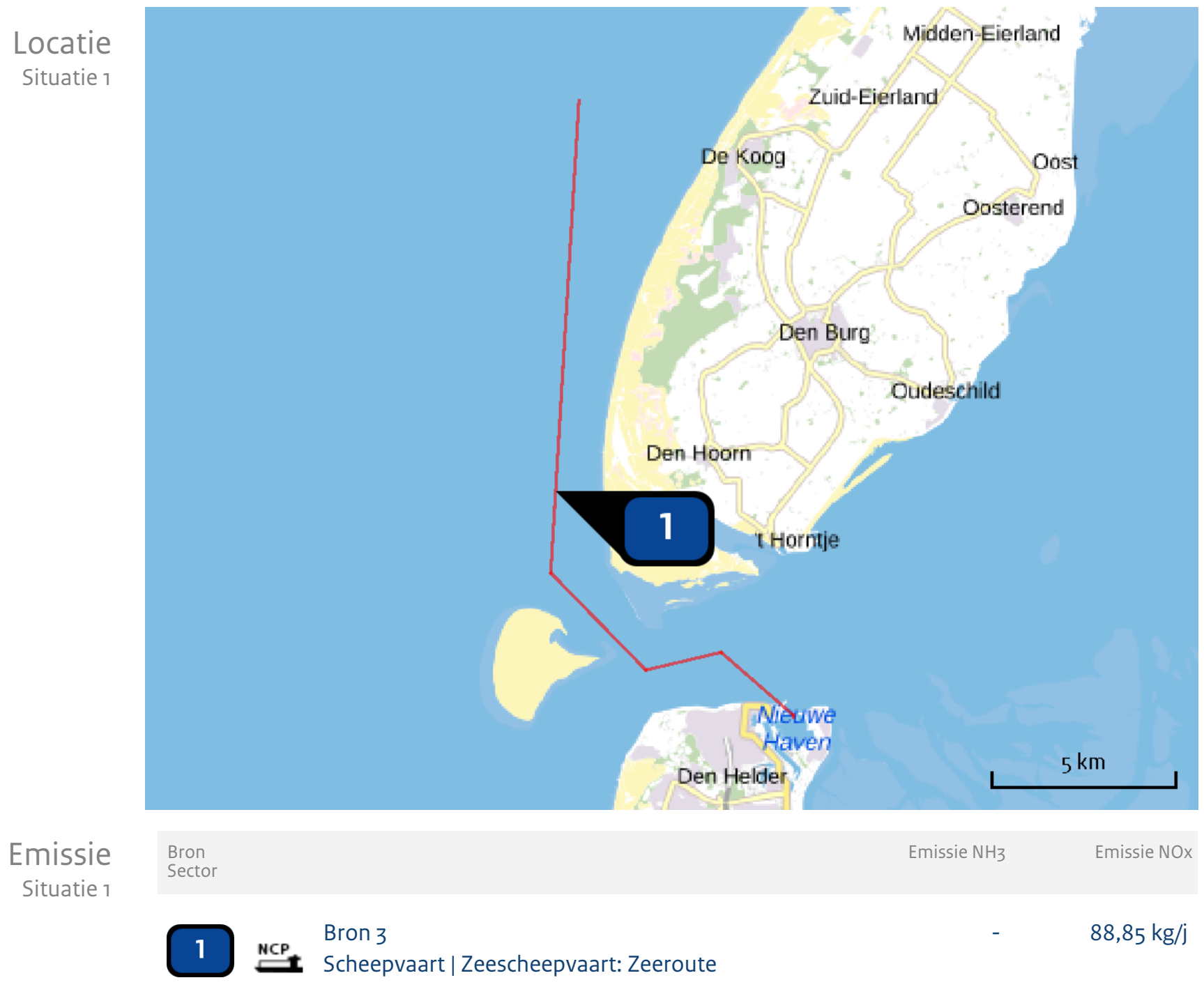




\author{
Emissie \\ (per bron) \\ Situatie 1
}

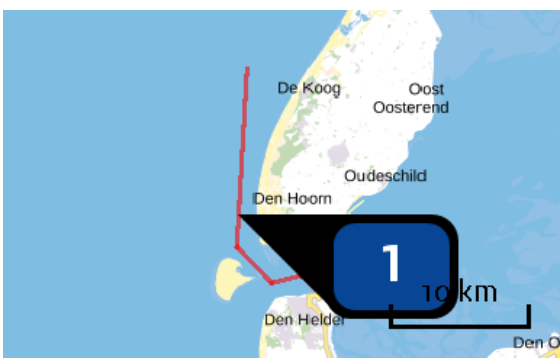

Naam
Locatie $(X, Y)$
NOX
Bron 3

108266, 559105

$88,85 \mathrm{~kg} / \mathrm{j}$

\begin{abstract}
Scheepstype
Omschrijving

Sleepboten,

werkschepen en

overige GT: 100-1599
\end{abstract}

Aantal bezoeken Stof

$8 /$ jaar NOx
Emissie

$88,85 \mathrm{~kg} / \mathrm{j}$ 
Hoewel verstrekte gegevens kunnen dienen ter onderbouwing van een vergunningaanvraag, kunnen er geen rechten aan worden ontleend. De eigenaar van AERIUS aanvaardt geen aansprakelijkheid voor de inhoud van de door de gebruiker aangeboden informatie. Bovenstaande gegevens zijn enkel bruikbaar tot er een nieuwe versie van AERIUS beschikbaar is. AERIUS is een geregistreerd handelsmerk in Europa. Alle rechten die niet expliciet worden verleend, zijn voorbehouden.

Rekenbasis Deze berekening is tot stand gekomen op basis van:

AERIUS versie 2020_20210525_2040287d5b

Database versie 2020_20210525_2040287d5b

Voor meer informatie over de gebruikte methodiek en data zie:

https://www.aerius.nl/nl/factsheets/release/aerius-calculator-2020 


\section{AERIUS À CALCULATOR}

Dit document bevat rekenresultaten van AERIUS Calculator. Het betreft de hoogst berekende stikstofbijdragen per

stikstofgevoelig Natura 2000-gebied, op basis van rekenpunten die overlappen met habitattypen en/of leefgebieden die aangewezen zijn in het kader van de Wet natuurbescherming, gekoppeld aan een aangewezen soort, of nog onbekend maar mogelijk wel relevant.

De berekening op basis van stikstofemissies gaat uit van de componenten ammoniak (NHz) en/of stikstofoxide (NOx).

Wilt u verder rekenen of gegevens wijzigen? Importeer de pdf dan in Calculator. Voor meer toelichting verwijzen wij u naar de website www.aerius.nl.
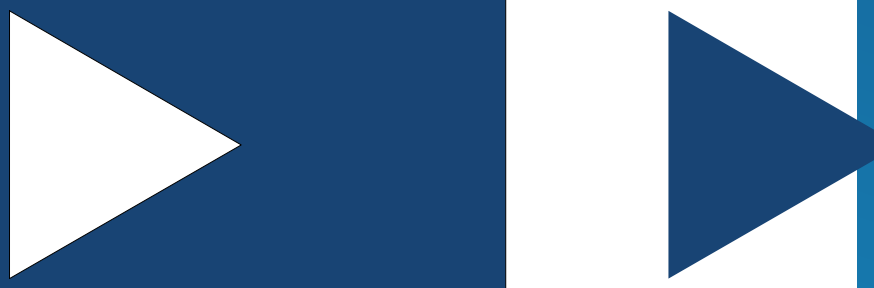

Berekening Situatie 1

- Kenmerken

- Samenvatting emissies

- Depositieresultaten

- Gedetailleerde emissiegegevens

Verdere toelichting over deze PDF kunt u vinden in een bijbehorende leeswijzer. Deze leeswijzer en overige documentatie is te raadplegen via:

https://www.aerius.nl/handleidingen-en-leeswijzers. 
Resultaten

\section{AERIUS Â CALCULATOR}

\section{Contact}

Rechtspersoon

Slow Mill Sustainable Power BV

Activiteit

Omschrijving

Pilot Slow Mill

Datum berekening

15 juni 2021, 11:45

Situatie 1

$\mathrm{NOx}$

$157,72 \mathrm{~kg} / \mathrm{j}$

$\mathrm{NH}_{3}$

Inrichtingslocatie

4 km ten westen van Texel (Paal 19), 1796AA Texel

AERIUS kenmerk

RZKBFW2ioVTC

Rekenjaar

2027
Rekenconfiguratie

Berekend voor natuurgebieden

Totale emissie

Resultaten

Hectare met hoogste bijdrage (mol/ha/j)

Toelichting
Natuurgebied

Uw berekening heeft geen depositieresultaten opgeleverd boven o,0o mol/ha/jr. 


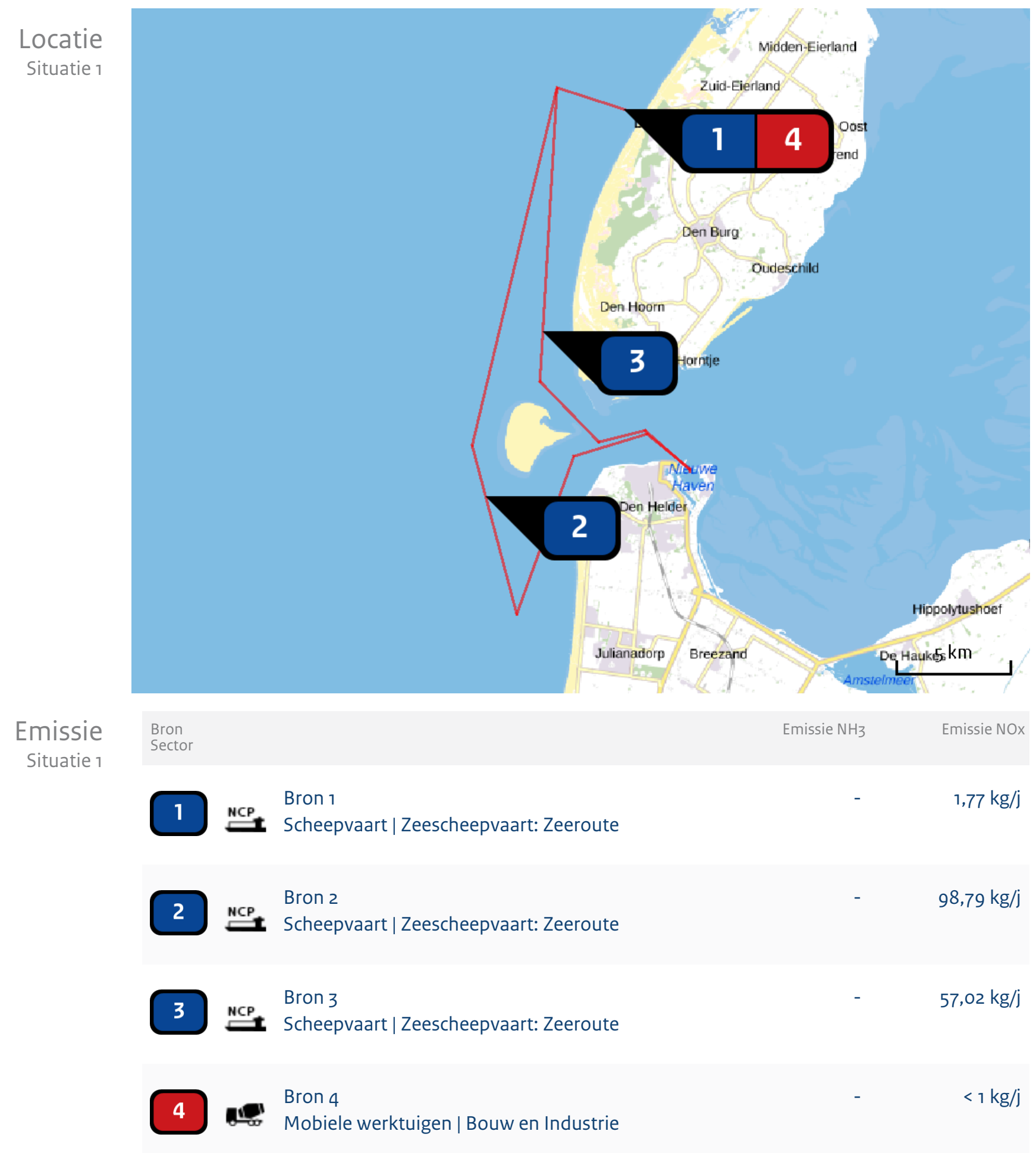




\author{
Emissie \\ (per bron) \\ Situatie 1
}

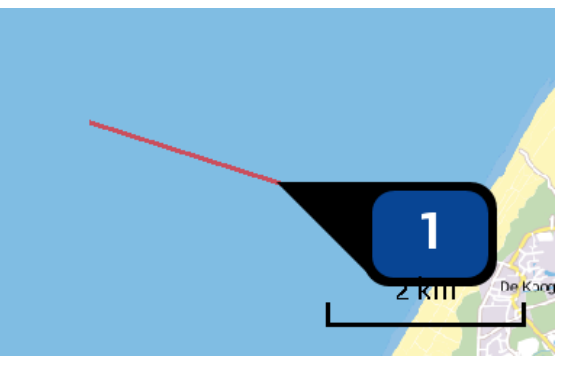

Naam

Locatie $(X, Y)$

NOx

Scheepstype

Omschrijving

M/N RAM

Sleepboten,

werkschepen en

overige GT: 100-1599

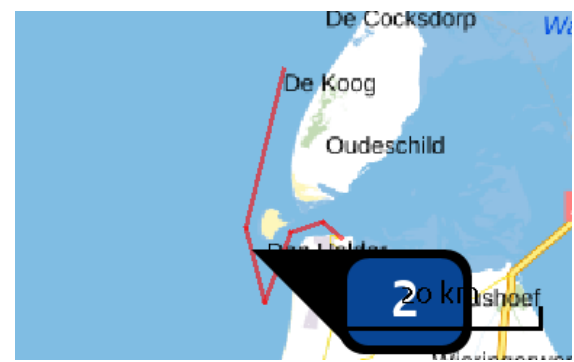

Naam

Locatie $(X, Y)$

NOx

Omschrijving

M/V RAM

Sleepboten,

werkschepen en

overige GT: 100-1599

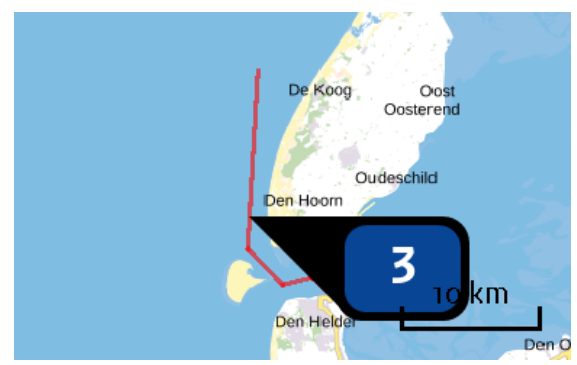

Naam

Locatie $(X, Y)$

NOx

\section{Bron 1}

110797, 569172

$1,77 \mathrm{~kg} / \mathrm{j}$
Aantal bezoeken Stof

1 / jaar NOx
Emissie

$1,77 \mathrm{~kg} / \mathrm{j}$
Bron 2

105765,551846

$98,79 \mathrm{~kg} / \mathrm{j}$
Aantal bezoeken Stof

6 / jaar NOx
Emissie $98,79 \mathrm{~kg} / \mathrm{j}$
Scheepstype

Omschrijving

Empiric

Sleepboten,

werkschepen en

overige GT: 100-1599
Bron 3 108266, 559105 $57,02 \mathrm{~kg} / \mathrm{j}$
Aantal bezoeken Stof

6 / jaar NOx

$57,02 \mathrm{~kg} / \mathrm{j}$ 


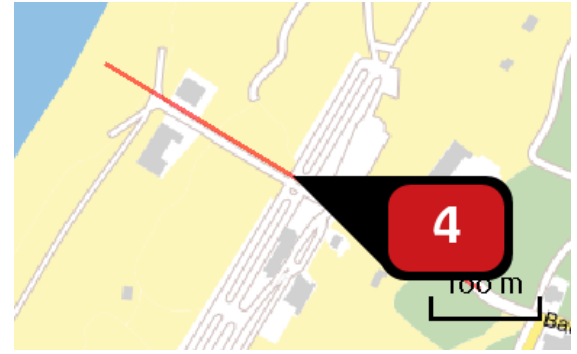

Voertuig

Omschrijving

Graafmachine

STAGE V, LPG 130

$<=\mathrm{kW}<560$,

bouwjaar 2019

(LPG)
Naam Bron 4

Locatie $(X, Y)$

112864, 568462

$<1 \mathrm{~kg} / \mathrm{j}$

NOx 
Hoewel verstrekte gegevens kunnen dienen ter onderbouwing van een vergunningaanvraag, kunnen er geen rechten aan worden ontleend. De eigenaar van AERIUS aanvaardt geen aansprakelijkheid voor de inhoud van de door de gebruiker aangeboden informatie. Bovenstaande gegevens zijn enkel bruikbaar tot er een nieuwe versie van AERIUS beschikbaar is. AERIUS is een geregistreerd handelsmerk in Europa. Alle rechten die niet expliciet worden verleend, zijn voorbehouden.

Rekenbasis Deze berekening is tot stand gekomen op basis van:

AERIUS versie 2020_20210525_2040287d5b

Database versie 2020_20210525_2040287d5b

Voor meer informatie over de gebruikte methodiek en data zie:

https://www.aerius.nl/nl/factsheets/release/aerius-calculator-2020 
Wageningen Marine Research

T: $+31(0) 317487000$

E: marine-research@wur.nl

www.wur.nl/marine-research

Bezoekers adres:

- Ankerpark 271781 AG Den Helder

- Korringaweg 7, 4401 NT Yerseke

- Haringkade 1, 1976 CP IJmuiden
Wageningen Marine Research levert met kennis, onafhankelijk wetenschappelijk onderzoek en advies een wezenlijke bijdrage aan een duurzamer, zorgvuldiger beheer, gebruik en bescherming van de natuurlijke rijkdommen in zee-, kust- en zoetwatergebieden.
Wageningen Marine Research is onderdeel van Wageningen University \& Research. Wageningen University \& Research is het samenwerkingsverband tussen Wageningen University en Stichting Wageningen Research en heeft als missie: 'To explore the potential of nature to improve the quality of life' 